Front Cover - Chicasaw plums (Prunus angustifolia) can be found in powerline rights-of-way, abandoned agricultural fields, and other mostly treeless, sandy areas around SRS. The colorful fruit is eaten by a variety of wildlife, and is edible to humans-usually in the form of sauces, pies, preserves, jams, and jellies. Chickasaw plum shrubs typically form dense thickets that provide valuable shelters and nesting habitats for birds. This year's cover photograph was taken in SRS's C Area by Al Mamatey of Savannah River Nuclear Solutions' Regulatory Integration \& Environmental Services Department. The cover was designed by Eleanor Justice of the company's Records Management and Policy Section/Communications and Knowledge Resource Development Group.

For more information about this report, or to obtain additional copies, contact

\author{
Ben Terry \\ Environmental Monitoring Services \\ Savannah River Nuclear Solutions \\ Building 735-B \\ Aiken, SC 29808 \\ Telephone: 803-952-6937 \\ E-mail address: benjamin.terry@srs.gov
}

This document was prepared in conjunction with work accomplished under Contract No. DE-AC0908SR22470 with the U.S. Department of Energy. This work was conducted under an agreement with, and funded by, the U.S. Government. Neither the U.S. Government nor its employees, nor any of its contractors or subcontractors or their employees, makes any expressed or implied (1) warranty or assumes any legal liability for the accuracy or completeness-or for the use or results of such use-of any information, product, or process disclosed; or (2) representation that such use or results of such use would not infringe on privately owned rights; or (3) endorsement or recommendation of any specifically identified commercial product, process, or service. Any views and opinions of authors expressed in this document do not necessarily state or reflect those of the U.S. Government, or of its contractors or subcontractors. 


\section{Savannah River Site Environmental Report for 2010}

Editor

Albert R. Mamatey
Project Manager

Jana D. Ackerman
Technical Consultant

Timothy Jannik
Prepared by

Savannah River Nuclear Solutions, LLC

Savannah River Site

Aiken, SC 29808

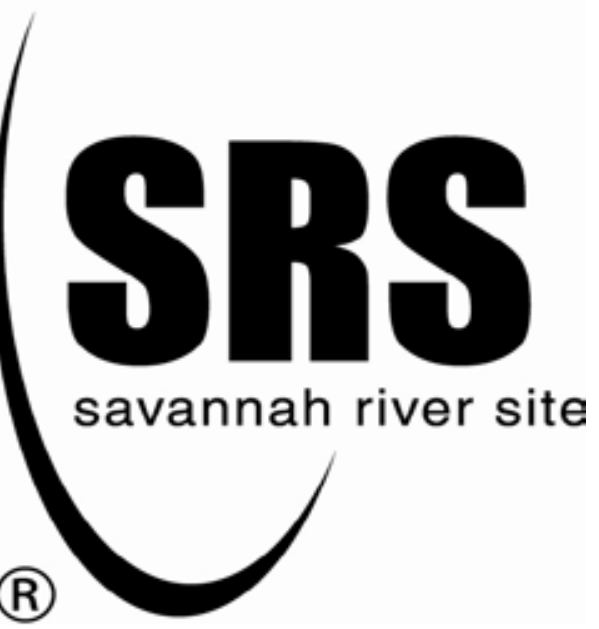





\section{Acknowledgements}

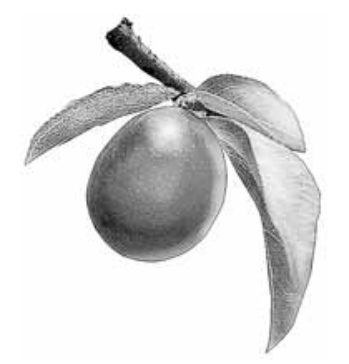

- The editor acknowledges with deep appreciation the efforts of the following individuals, who (in addition to the chapter authors, contributors, and compilers) conducted reviews for-and/or provided valuable resources, information, or technical data to- the Savannah River Site Environmental Report for 2010:

$\begin{array}{llll}\text { Angela Benfield } & \text { Larry Koffman } & \text { Ted Motyka } & \text { Michael Theiszmann } \\ \text { Dean Campbell } & \text { Walt Kubilius } & \text { Linda Nass } & \text { Jeff Thibault } \\ \text { Tiajuana Cochnauer } & \text { David Lee } & \text { Ross Natoli } & \text { Rob Turner } \\ \text { Brian Culligan } & \text { Linda Lee } & \text { Eric Nelson } & \text { Robin Utsey } \\ \text { Joe Dixon } & \text { Patricia Lee } & \text { Lisa Oliver } & \text { Julie Wilson } \\ \text { Megan Elliott } & \text { Mary Beth Lloyd } & \text { Scott Ray } & \text { David Wolfe } \\ \text { Chuck Hunter } & \text { Sherrod Maxwell } & \text { Natalie Lopez } & \text { David Yannitell } \\ \text { Sherold Johnson } & \text { Carl Mazzola } & \text { Jeff Ross } & \text { Linda Youmans-McDonald } \\ \text { Rick Kelley } & \text { J. Vaun McArthur } & \text { Rebecca Scheffler } & \\ \text { Steve King } & \text { Ken McLeod } & \text { Don Stevenson } & \end{array}$

Clemson University Environmental Engineering/Earth Sciences Department Technical Reviewers

Dr. Timothy A. DeVol - Professor

Dr. Robert A. Fjeld - Professor Emeritus

Dr. Fred J. Moltz, III - Research Professor/Distinguished Scientist Emeritus

Dr. Thomas J. Overcamp - Professor

- Listed below are those who provided expert publications support:
Kaye Atkins
Lisa McCullough
Sheila Ruff
Eleanor Justice
Kandi Mulligan
Joan Toole

- A special thanks to Gail Whitney for coordinating the DOE-SR review and approval process, which requires dedication and support from both DOE-SR and SRNS:

$\begin{array}{llll}\begin{array}{l}\text { Amy Caver } \\ \text { (DOE-SR) }\end{array} & \begin{array}{l}\text { David Hoel } \\ \text { (DOE-SR) }\end{array} & \begin{array}{l}\text { Sherry Southern } \\ \text { (DOE-SR) }\end{array} & \begin{array}{l}\text { Kevin Schmidt } \\ \text { (SRNS) }\end{array} \\ \begin{array}{l}\text { Deborah Caver } \\ \text { (DOE-SR) }\end{array} & \begin{array}{l}\text { Gary Hoover } \\ \text { (DOE-SR) }\end{array} & \begin{array}{l}\text { Dan Campbell } \\ \text { (SRNS) }\end{array} & \\ \text { Andrew Grainger } & \text { Maatsi Ndingwan } & \text { Tom Coughenour } & \\ \text { (DOE-SR) } & \text { (DOE-SR) } & \text { (SRNS) }\end{array}$

- Thanks to Rachel Baker, Roy Blackwell, Jeff Bussey, Chuck Harvel, Michael Kennedy, Roger Neal, Robert Seremak, David Sharpe, James Tussey, and Ray Wilcauskas for providing computer hardware and software support.

- Marvin Stewart is acknowledged with appreciation for providing Internet expertise and computer software support. 
- Gratitude is expressed to the following for management, administrative, field, and other support:

$\begin{array}{llll}\text { Brenda Alejo } & \text { Sharon Crawford } & \text { David Hughey } & \text { David Roberts } \\ \text { Perry Allen } & \text { Janet Curtis } & \text { Jeannette Hyatt } & \text { Jackie Rourk } \\ \text { Rob Backer } & \text { Karl Damon } & \text { Rosa Jackson } & \text { Dennis Ryan } \\ \text { Phil Baker } & \text { Libby Danielowich } & \text { Kevin Kostelnik } & \text { Eloy Saldivar } \\ \text { Jackie Banks } & \text { Daryl Doman } & \text { Bill Lewis } & \text { Patrick Shaw } \\ \text { Sammie Baughman } & \text { Dale Duke } & \text { Cheryl Lewis } & \text { Debra Shea } \\ \text { Mary Berry } & \text { Wileva Dunbar } & \text { Kelly Ling } & \text { Allan Sikes } \\ \text { Connie Black } & \text { Jason Durden } & \text { Bill Macky } & \text { Mark Spires } \\ \text { Stacie Britt } & \text { Ross Fanning } & \text { Phillip Marshall } & \text { Jim Stafford } \\ \text { Nancy Brown } & \text { Richard Farr } & \text { Owen Mason } & \text { Fred Stanland } \\ \text { Mike Burroughs } & \text { Mary Flora } & \text { Janet McClearen } & \text { David Stevens } \\ \text { Will Callicott } & \text { Lyman Fogle } & \text { Tony Melton } & \text { Dan Stewart } \\ \text { Kim Cauthen } & \text { Rodney Gantt } & \text { Amy Meyer } & \text { Becky Sturdivant } \\ \text { Joy Chapman } & \text { Lisa Gillespie } & \text { Grace Miller } & \text { Marisa Trahan } \\ \text { Sharon Chapman } & \text { Brenda Goff } & \text { Ken Mishoe } & \text { John Vaughn } \\ \text { Becky Chavous } & \text { Calvin Hamilton } & \text { David Palmer } & \text { Robin Wainwright } \\ \text { Ken Cheeks } & \text { Tim Hartley } & \text { Karen Palmer } & \text { Mtesa Wright } \\ \text { Vanessa Cofer } & \text { Jack Herrington } & \text { Wayne Pippen } & \text { Tommy Young } \\ \text { Gene Cooke } & \text { Minnie Hightower } & \text { Christine Posey } & \\ \text { Roslyn Cooke } & \text { Mike Hughes } & \text { Thomasina Robinson } & \\ & & & \end{array}$




\section{To Our Readers}

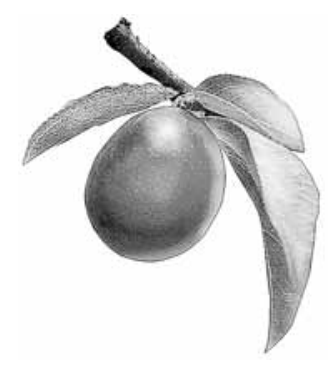

$\mathbf{S}$ RS has had an extensive environmental monitoring program in place since 1951 (before site startup). In the 1950s, data generated by the onsite environmental monitoring program were reported in site documents. Beginning in 1959, data from offsite environmental surveillance activities were presented in reports issued for public dissemination. SRS reported onsite and offsite environmental monitoring activities separately until 1985, when data from both programs were merged into one public document.

The Savannah River Site Environmental Report for 2010 (SRNS-STI-2011-00059) is an overview of effluent monitoring and environmental surveillance activities conducted on and in the vicinity of SRS from January 1 through December 31, 2010_including the site's performance against applicable standards and requirements. Details are provided on major programs such as the Environmental Management System (EMS) and permit compliance. Information for the 2010 report was compiled and prepared by the Regulatory Integration \& Environmental Services Department of Savannah River Nuclear Solutions LLC (SRNS), the site's M\&O contractor. The "Environmental Monitoring Program Management Plan" [SRS EM Plan, 2010] documents (1) the rationale and objectives for the monitoring program, (2) the frequency of monitoring and analysis, (3) the various sampling locations, and (4) the specific analytical and sampling protocols used. The "Environmental Monitoring Quality Assurance Project Plan" [SRS EM QA Plan, 2010] describes the associated quality assurance requirements.

Complete data tables are included on the $\mathrm{CD}$ inside the back cover of this report. The CD also features (1) an electronic version of the report; (2) an appendix of site, environmental sampling location, dose, and groundwater maps; and (3) annual (2010) reports from a number of other SRS organizations. The data tables generally are presented as unformatted Excel spreadsheets; they are not intended to be printed. However, if printing is desired, the user can modify the "Page Setup" parameters in Excel as needed. If printing of the "SRS Maps" on the CD is desired, it is recommended (to ensure clarity) that figures $1-25$ be printed $8.5 \times 11$ inches, figures $26-31$ be printed $36 \times 32$ inches, and figures $32-34$ be printed $34 \times 33$ inches.

The following information should aid the reader in interpreting data in this report:

- Variations in environmental report data reflect year-to-year changes in the routine monitoring program, as well as occasional difficulties in sample collection or analysis. Examples of such difficulties include adverse environmental conditions (such as flooding or drought), sampling or analytical equipment malfunctions, sample handling and transportation issues, compromise of the samples in the preparation laboratories or counting room.

- Table heading abbreviations may include the following: (1) "N" is number of observations; (2) "SampleCon" is sample concentration; (3) "SampleStd" is standard deviation; and (4) "Sig" is significance, with "Yes" meaning detectable and "No" meaning less than the analytical method detection limit.

- Analytical results and their corresponding uncertainty terms generally are reported with up to three significant figures. This is a function of the computer software used and may imply greater accuracy in the reported results than the analyses would allow.

- Units of measure and their abbreviations are defined in the glossary (beginning on page G-1) and in charts at the back of the report. The reported uncertainty of a single measurement reflects only the counting error-not other components of random and systematic error in the measurement processso some results may imply a greater confidence than the determination would suggest.

- An uncertainty quoted with a mean value represents the standard deviation of the mean value. This 
number is calculated from the uncertainties of the individual results. For an unweighted mean value, the uncertainty is the sum of the variances for the individual values divided by the number of individual results squared. For a weighted mean value, the uncertainty is the sum of the weighted variances for the individual values divided by the square of the sum of the weights.

- All values represent the weighted average of all acceptable analyses of a sample for a particular analyte. Samples may have undergone multiple analyses for quality assurance purposes or to determine if radionuclides are present. For certain radionuclides, quantifiable concentrations may be below the minimum detectable activity of the analysis, in which case the actual concentration value is presented to satisfy DOE reporting guidelines.

- The generic term "dose," as used in the report, refers to the committed effective dose (50-year committed dose) from internal deposition of radionuclides and to the effective dose attributable to beta/ gamma radiation from sources external to the body.

\section{Report Available on Web}

Readers can find the SRS Environmental Report on the World Wide Web at the following address: http://www.srs.gov/general/pubs/ERsum/index.html. 


\section{Contents}

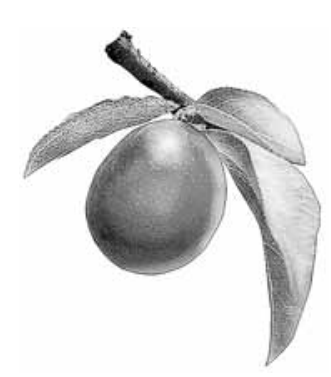

List of Figures. . $\mathrm{ix}$

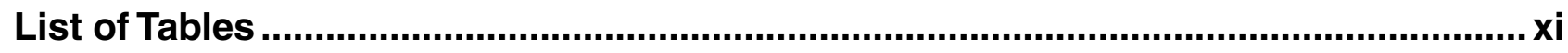

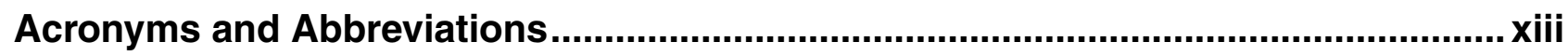

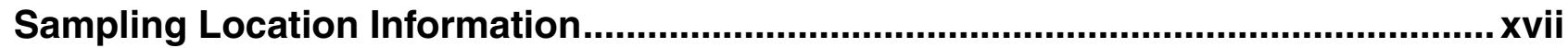

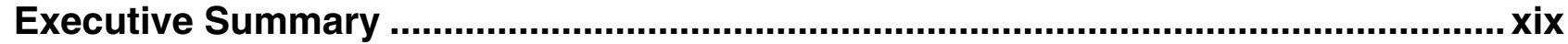

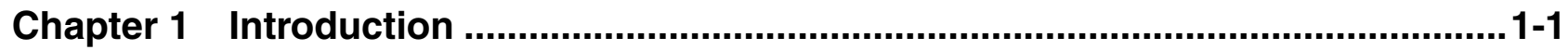

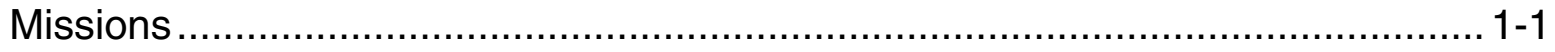

Site Location, Demographics and Environment ............................................ 1-1

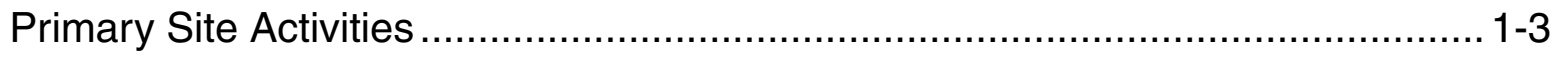

Chapter 2 Environmental Management System ..................................................... 2-1

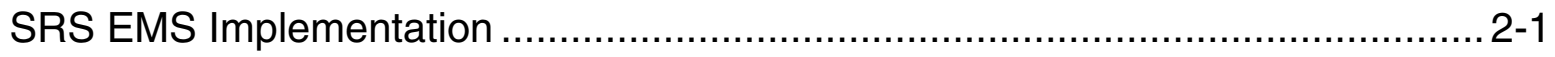

Chapter 3 Environmental Compliance ...................................................................... 3-1

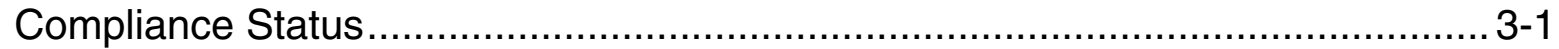

Other Environmental Issues/Actions ............................................................. 3-16

Continuous-Release Reporting............................................................. 3-19

Unplanned Releases.......................................................................... 39

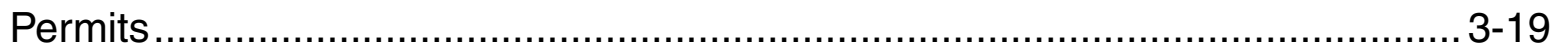

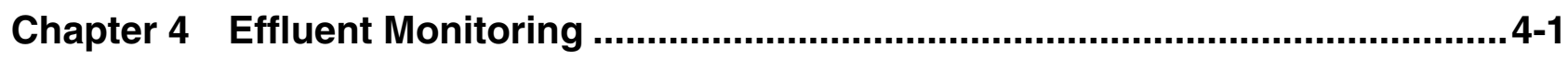

Radiological Monitoring ............................................................................. 4

Nonradiological Monitoring ...................................................................... 4-4

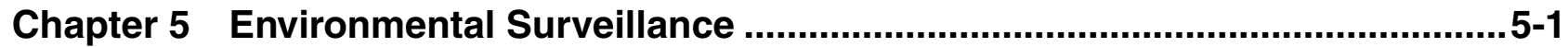

Radiological Surveillance........................................................................

Nonradiological Surveillance................................................................. 5-18

Chapter 6 Potential Radiation Doses ..................................................................... 6-1

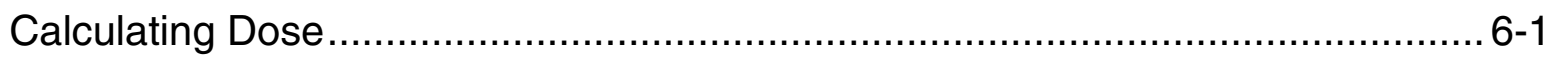

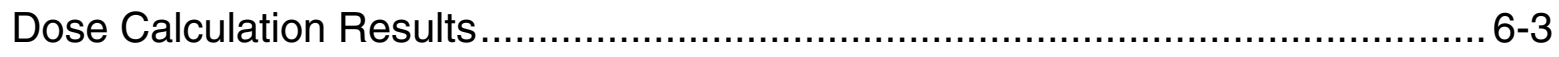

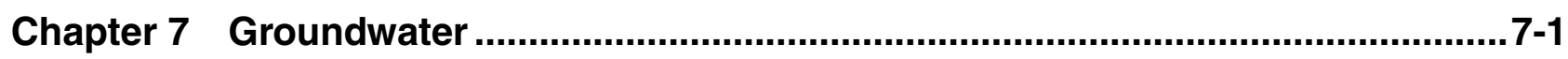

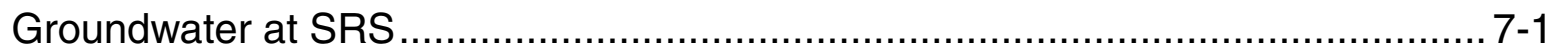

Groundwater Protection Program at SRS .................................................... 
Chapter 8 Quality Assurance

Environmental QA Program Integration

8-1

Program Samples 8-1

Appendix A Applicable Guidelines, Standards, and Regulations

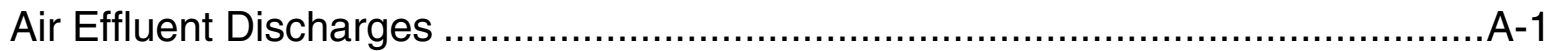

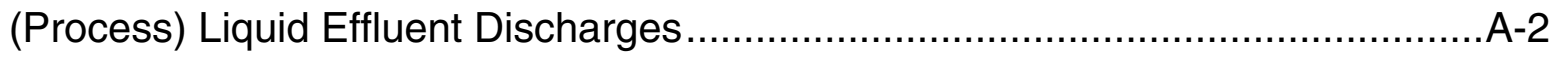

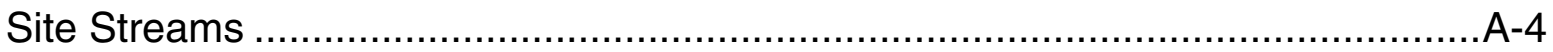

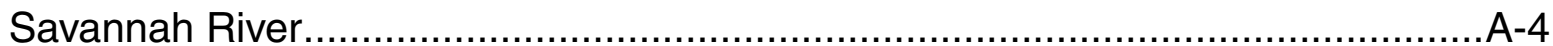

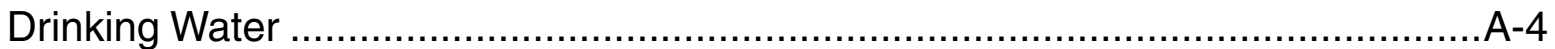

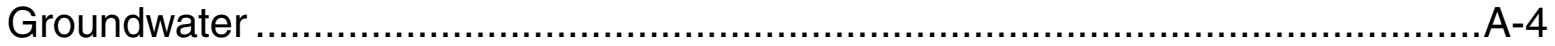

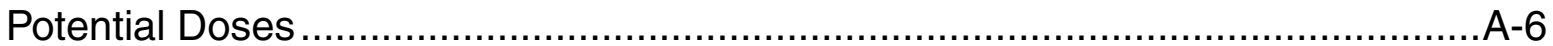

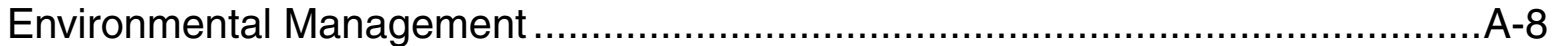

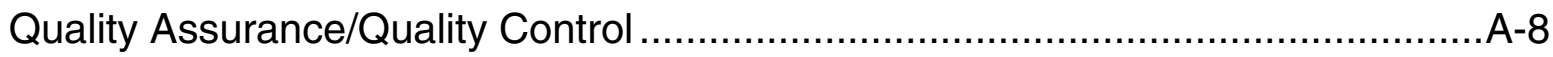

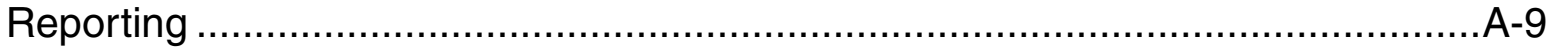

Appendix B Radionuclide and Chemical Nomenclature ........................................ B-1

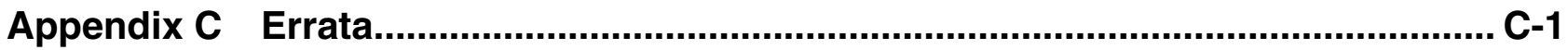

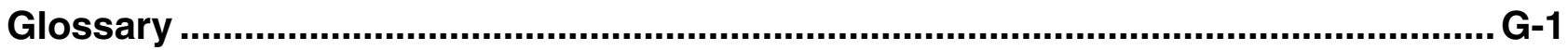

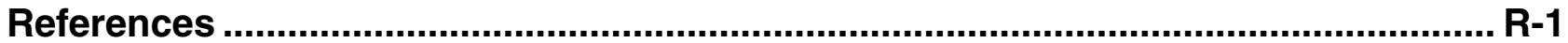

\section{Reports for 2010 Contained on Accompanying CD}

SRS Environmental Report

SRS Environmental Data/Maps

Area Completion Projects

Liquid Waste Operations

Solid Waste Management

Savannah River Archaeological Research Program

Savannah River Ecology Laboratory

Savannah River National Laboratory Environmental Dose Assessment Manual

USDA Forest Service - Savannah River

SRS Environmental Management System Description Manual

SRS Environmental Policy - FY 2011 


\section{List of Figures}

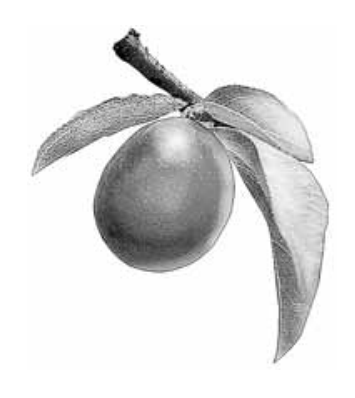

Chapter 1 Introduction $1-1$

Figure 1-1 The Savannah River Site. $1-2$

Chapter 2 Environmental Management System.

Figure 2-1 Environmental Management System Integration............................ 2-2

Figure 2-2 DOE-SR Energy Reduction Performance..................................... 2-9

Figure 2-3 Domestic/Process Water Reduction Performance .......................... 2-9

Figure 2-4 Increased E85 Usage at SRS .............................................. 2-9

Figure 2-5 SRS Gasoline Reduction Performance ................................... 2-10

Chapter $4 \quad$ Effluent Monitoring …................................................................... 4-1

Figure 4-1 Ten-Year History of SRS Annual Atmospheric Tritium Releases ...... 4-2

Figure 4-2 Ten-Year History of Direct Releases of Tritium to SRS Streams ...... 4-4

Chapter 5 Environmental Surveillance

Figure 5-1 Gross Beta-In-Air Concentrations Measured in Glass Fiber Filters for 15 Locations, 2010

Figure 5-2 Ambient/Atmospheric Tritium-In-Air Concentrations $\left(\mathrm{pCi} / \mathrm{m}^{3}\right)$, 2006-2010 5-5

Figure 5-3 Average Tritium-in-Rainwater Concentrations, 2006-2010 5-6

Figure 5-4 Five-Year Trend of Ambient Annual Average and Maximum Gamma Exposure Levels (in mrem).

Figure 5-5 Estimated Tritium Migration from SRS Seepage Basins and SWDF to Site Streams, 2001-2010 .......................................... 5-9

Figure 5-6 SRS Tritium Transport Summary, 1960-2010 ............................. 5-11

Figure 5-7 Maximum Cesium-137 Concentrations in Wildlife Field and Lab Measurements (pCi/g), 2006-2010

Figure 5-8 Average Cesium-137 Concentrations in Deer and Hogs (pCi/g), 2006-2010 
Figure 5-9 Three-Year Trend Chart of Cesium-137 Concentrations in Soil (pCi/kg).....

Figure 5-10 Three-Year Trend Chart of Cesium-137 Concentrations in Vegetation (pCi/kg).

Figure 5-11 Creek Plantation Ambient Gamma Exposure Rates for 10 Transects

Chapter 6 Potential Radiation Doses.

Figure 6-1 Ten-Year History of SRS Maximum Potential All-Pathway Doses .... 6-8

Figure 6-2 Ten-Year History of SRS Creek-Mouth Fisherman's Doses ........... 6-12

\section{Chapter 7 Groundwater}

Figure 7-1 Hydrostratigraphic Units at SRS.

Figure 7-2 Groundwater at SRS

Appendix A Applicable Guidelines, Standards, and Regulations. 


\section{List of Tables}

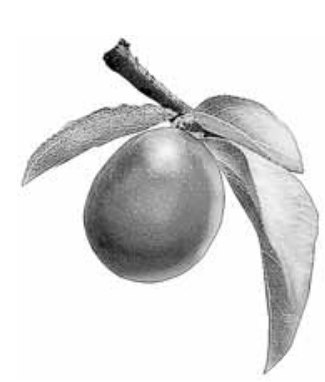

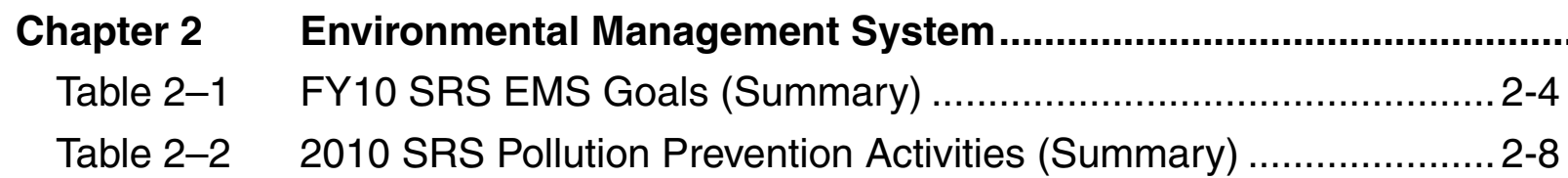

Chapter $3 \quad$ Compliance Summary......................................................................... 3-1

Table 3-1 Laws/Regulations Applicable to SRS ............................................ 3-2

Table 3-2 Summary of SRS-Related NEPA Reviews in $2010 \ldots \ldots \ldots \ldots \ldots \ldots \ldots . . . . . .5$

Table 3-3 SRS Reporting Requirements under "Federal Compliance with

Right-to-Know Laws and Pollution Prevention Requirements"

(Executive Order 12856)

Table 3-4 NOV/NOAV Summary, 2006-2010......................................... 3-17

Table 3-5 Routine Environmental External Audit and Inspection Summary ... 3-18

Table 3-6 SRS Construction and Operating Permits, 2010 ......................... 3-19

Chapter $4 \quad$ Effluent Monitoring …........................................................................ 4-1

Table 4-1 SRS Estimated SCDHEC Standard 2 Pollutant Air Emissions,

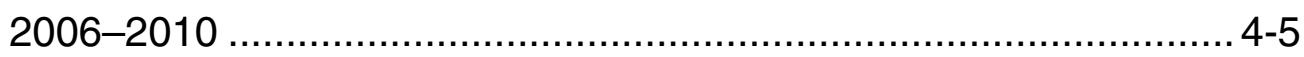

Table 4-2 2010 Boiler Stack Test Results ................................................ 4-6

Chapter $5 \quad$ Environmental Surveillance .............................................................. 5-1

Table 5-1 Average Gross Alpha in Air Filter Results (pCi/m³), 2006-2010 ...... 5-4

Table 5-2 Average Gross Beta in Air Filter Results (pCi/m ${ }^{3}$ ), 2006-2010 ........ 5-4

Table 5-3 Average 2010 Concentrations of Radioactivity in SRS Streams ...... 5-8

Table 5-4 Strontium-89,90, Technetium-99, lodine-129, and Cesium-137 Migration Estimates ................................................................ 5-10

Table 5-5 Average 2010 Concentrations of Radioactivity in the Savannah River ................................................................. 5-10 


\section{Chapter 6 Potential Radiation Doses}

Table 6-1 2010 Radioactive Liquid Release Source Term and 12-Month

Average Downriver Radionuclide Concentrations Compared to

EPA's Drinking Water Maximum Contaminant Levels (MCLs)

Table 6-2 Potential Dose to the Maximally Exposed Individual from SRS

Liquid Releases in 2010

Table 6-3 Potential Dose to the Maximally Exposed Individual from SRS

Atmospheric Releases in 2010

Table 6-4 2010 Maximum Potential All-Pathway and Sportsman Doses

Compared to the DOE All-Pathway Dose Standard

Table 6-5 Potential Lifetime Risks from the Consumption of Savannah River

Fish Compared to Dose Standards

Appendix A Applicable Guidelines, Standards, and Regulations...........................-1

Table A-1 National Ambient Air Quality Standards for Criteria Air Pollutants 2010

Table A-2 Airborne Emission Limits for SRS Coal-Fired Boilers A-4

Table A-3 Airborne Emission Limits for SRS Fuel Oil-Fired Packag

Table A-4

Airborne Emission Limits for SRS 784-7A Biomass Boiler. A-5

Table A-5 Airborne Emission Limits for SRS 784-7A Oil-Fired Package Boiler A-5

Table A-6 South Carolina Water Quality Standards for Freshwaters A-6 


\section{Acronyms and Abbreviations}

Note: Sampling location abbreviations can be found on page xvii.

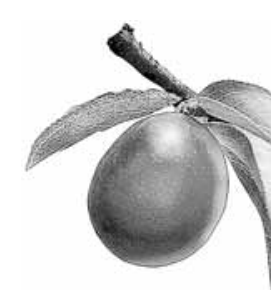

$\mathbf{A}$

ACP - Area Completion Projects

ACM - Asbestos-containing material

ALARA - As low as reasonably achievable

ANSI - American National Standards Institute

ANS - Academy of Natural Sciences

AOP - Annual Operational Plan

ARRA - American Recovery and Reinvestment Act

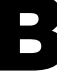

BAT - Best Available Technology

BCG - Biota concentration guide

BE - Biological Evaluation

BGN - Burial Ground North

bgs - Below ground surface

BJWSA - Beaufort-Jasper Water and Sewer Authority

BTU - British thermal unit

CA - Corrective Action

CAA - Clean Air Act

CAAA - Clean Air Act Amendments of 1990

CAB - Citizens Advisory Board

CAT - Consolidated Annual Training

CD - Compact disk

C\&D - Construction and Demolition

CERCLA - Comprehensive Environmental Response, Compensation, and Liability Act (Superfund)
CFR - Code of Federal Regulations

CHR - Center for Hydrogen Research

Ci - Curie

CMIR - Corrective Measures Implementation Report

COE - U. S. Army Corps of Engineers

COR - Challenges, Opportunities, and Resolution

CSRA - Central Savannah River Area

CWA - Clean Water Act

D

DCG - Derived concentration guide

DOE - U.S. Department of Energy

DOECAP - U.S. Department of Energy Consolidated Audit Program

DOE-HQ - U.S. Department of Energy-Headquarters

DOE-SR - U.S. Department of Energy-Savannah River Operations Office

DMWE - Data Management and Waste Engineering

DMR - Discharge Monitoring Report

DWS - Drinking water standards

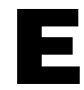

EA - Environmental assessment

EEC - Environment evaluation checklist

EIS - Environmental impact statement

EM - Environmental Monitoring

EMCAP - Environmental Management Consolidated Audit Program

EML - Environmental Monitoring Lab

EMS - Environmental Management System 
EO - Executive Order

EPA - U.S. Environmental Protection Agency

EPCRA - Emergency Planning and Community Rightto-Know Act

EQMD - Environmental Quality Management Division (DOE-SR)

ERA - Environmental Resource Associates

ESD - Explanation of Significant Difference

ESA - Endangered Species Act

ESEC - Environmental Science Educator's Cooperative

FEB - Facility Evaluation Board

FFA - Federal Facility Agreement

FFCAct - Federal Facility Compliance Act

FIFRA - Federal Insecticide, Fungicide, and Rodenticide Act

FIMS - Flow injection mercury system

FONSI - Finding of no significant impact

FWS - U.S. Fish and Wildlife Service

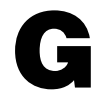

GDNR - Georgia Department of Natural Resources

GET - General employee training

GNEP - Global Nuclear Energy Partnership

GSMP - Groundwater Surveillance Monitoring Program

GSA - General Separations Area

GTCC - Greater Than Class C

Gy - Gray

IAPCR - Interim Action Post Closure Report

ICP-AES - Inductively coupled plasma atomic emission spectrometry

ICP-MS - Inductively coupled plasma mass spectrometry
ICRP - International Commission on Radiological Protection

ISMS - Integrated Safety Management System

ISO - International Organization for Standardization

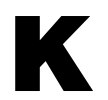

kg - Kilogram

LDR - Land disposal restrictions

LLW - Low-level radioactive waste

LWO - Liquid Waste Operations

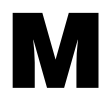

M\&O - Management and Operating

MACT - Maximum achievable control technology

MAPEP - Mixed Analyte Performance Evaluation Program

$\mathbf{m C i}$ - Millicurie

MCL - Maximum contaminant level

MDC - Minimum detectable concentration

MFFF - Mixed Oxide Fuel Fabrication Facility

$\mathbf{M g} / \mathbf{L}$ - Milligrams per liter

$\mathbf{m L}$ - Milliliter

MOA - Memoranda of agreement

MOU - Memorandum of understanding

MOX - Mixed oxide

mrem - Millirem

mSv - Millisievert

$\mathbf{N}$

NBN - No building number

NEPA - National Environmental Policy Act

NESHAP - National Emission Standards for Hazardous Air Pollutants 
NHPA - National Historic Preservation Act

NOV - Notice of violation

NPDES - National Pollutant Discharge Elimination System

NRC - Nuclear Regulatory Commission

NRMP - Natural Resources Management Plan

NWP - Nationwide permit

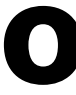

ODS - Ozone-depleting substance

OFI - Opportunity for improvement

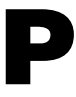

P2 - Pollution prevention program

PA - Performance assessment

PAR - P and R (Pond)

PCB - Polychlorinated biphenyl

PCR - Post-construction report

pCi/L - Picocuries per liter

PEIS - Programmatic environmental impact statement

PM - Particulate matter

pH - Measure of the hydrogen ion concentration in an aqueous solution (acidic solutions, $\mathrm{pH}<7$; basic solutions, $\mathrm{pH}>7$; and neutral solutions, $\mathrm{pH}=7$ )

POC - Point of contact

ppb - Parts per billion

ppm - Parts per million

PUREX - Plutonium Uranium Extraction Process

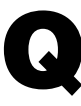

QA - Quality assurance

QC - Quality control

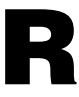

RACR - Remedial Action Completion Report

RCRA - Resource Conservation and Recovery Act
RFI/RI - RCRA facility investigation/remedial investigation

RI\&ES - Regulatory Integration and Environmental Services

RHA - Rivers and Harbors Act

RM - River mile

RMP - Risk management program

RMW - Radioactive Mixed Waste

ROD - Record of decision

SA - Supplement analysis

SARA - Superfund Amendments and Reauthorization Act

Savannah I\&D - Savannah Industrial and Domestic Water Supply Plant

SCDHEC - South Carolina Department of Health and Environmental Control

SDWA - Safe Drinking Water Act

SE - Removal site evaluation

SEIS - Supplemental environmental impact statement

SEMC - Senior Environmental Managers Council

SES - Shealy Environmental Services, Inc.

SCE\&G - South Carolina Electric and Gas

SIRIM - Site Item Reportability and Issues Management

SLA - Service level agreement

SRARP - Savannah River Archaeological Research Program

SREL - Savannah River Ecology Laboratory

S/RID - Standards/Requirements Identification Document

SRIT - SRS Regulatory Integration Team

SRNL - Savannah River National Laboratory

SRNS - Savannah River Nuclear Solutions, LLC

SRR - Savannah River Remediation LLC

SRS - Savannah River Site

STAR - Site Tracking, Analysis, and Reporting

STP - Site Treatment Plan 
SWDF - Solid Waste Disposal Facility

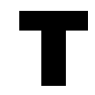

TCLP - Toxicity characteristic leaching procedure

TEAM - Transformational Energy Action Management

TEM - Transmission electron microscopy

TLD - Thermoluminescent dosimeter

TDS - Total dissolved solids

TRI - Toxic Release Inventory

TRU - Transuranic waste

TSCA - Toxic Substances Control Act

TSS - Total suspended solids

TVA - Tennessee Valley Authority

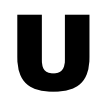

USFS-SR - U.S. Department of Agriculture Forest Service-Savannah River

$\boldsymbol{\mu g} / \mathbf{L}-$ Micrograms per liter

$\boldsymbol{\mu g} / \mathbf{m}^{3}-$ Micrograms per cubic meter $\boldsymbol{\mu S} / \mathbf{c m}$ - Microsieverts per centimeter

USGS - U.S. Geological Survey

UST - Underground storage tank

UTM - Universal Transverse Mercator

V

VEGP - Vogtle Electric Generating Plant

VOC - Volatile organic compound

$\mathbf{W}$

WAC - Waste Acceptance Criteria

WIPP - Waste Isolation Pilot Plant

W/Min - Waste minimization

WP - Water pollution

WQC - Water quality certification

WS - Water supply

WSI-SRS - Wackenhut Services Incorporated-Savannah River Site

WSRC - Washington Savannah River Company 


\section{Sampling Location Information}

Note: This section contains sampling location abbreviations used in the text and/or on the sampling location maps. It also contains a list of sampling locations known by more than one name (see next page).

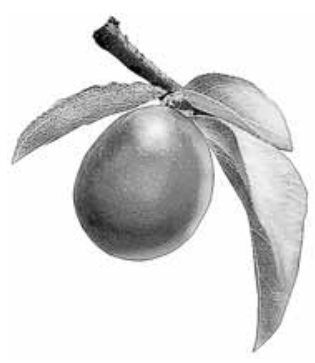

\begin{tabular}{|ll|}
\hline Location Abbreviation & Location Name/Other Applicable Information \\
\hline $4 M$ & Four Mile \\
\hline 4MB & Fourmile Branch (Four Mile Creek) \\
\hline BMC & Four Mile Creek \\
\hline BG & Beaver Dam Creek \\
\hline EAV & Burial Ground \\
\hline FM & E-Area Vaults \\
\hline FMB & Four Mile \\
\hline FMC & Fourmile Branch (Four Mile Creek) \\
\hline GAP & Four Mile Creek (Fourmile Branch) \\
\hline HP & Georgia Power Company \\
\hline HWY & HP (sampling location designation only; not an actual abbreviation) \\
\hline KP & Highway \\
\hline L3R & Kennedy Pond \\
\hline NRC & Lower Three Runs \\
\hline NSB L\&D & Nuclear Regulatory Commission \\
\hline PAR & New Savannah Bluff Lock \& Dam (Augusta Lock and Dam) \\
\hline PB & "P and R" Pond \\
\hline RM & Pen Branch \\
\hline SC & River Mile \\
\hline SWDF & Steel Creek \\
\hline TB & Solid Waste Disposal Facility \\
\hline TC & Tims Branch \\
\hline TNX & Tinker Creek \\
\hline U3R & Multipurpose Pilot Plant Campus \\
\hline VEGP & Upper Three Runs \\
\hline & Vogtle Electric Generating Plant (Plant Vogtle) \\
\hline
\end{tabular}




\section{Sampling Locations Known by More Than One Name}

Augusta Lock and Dam; New Savannah Bluff Lock and Dam

Beaver Dam Creek; 400-D

Four Mile Creek-2B; Four Mile Creek at Road C

Four Mile Creek-3A; Four Mile Creek at Road C

Lower Three Runs-2; Lower Three Runs at Patterson Mill Road

Lower Three Runs-3; Lower Three Runs at Highway 125

Pen Branch-3; Pen Branch at Road A-13-2

R-Area downstream of R-1; 100-R

River Mile 118.8; U.S. Highway 301 Bridge Area; Highway 301; US 301

River Mile 129.1; Lower Three Runs Mouth

River Mile 141.5; Steel Creek Boat Ramp

River Mile 150.4; Vogtle Discharge

River Mile 152.1; Beaver Dam Creek Mouth

River Mile 157.2; Upper Three Runs Mouth

River Mile 160.0; Dernier Landing

Steel Creek at Road A; Steel Creek-4; Steel Creek-4 at Road A; Steel Creek at Highway 125

Tims Branch at Road C; Tims Branch-5

Tinker Creek at Kennedy Pond; Tinker Creek-1

Upper Three Runs-4; Upper Three Runs-4 at Road A; Upper Three Runs at Road A;

Upper Three Runs at Road 125

Upper Three Runs-1A; Upper Three Runs-1A at Road 8-1

Upper Three Runs-3; Upper Three Runs at Road C

Highway 17 Bridge; Houlihan Bridge

Stokes Bluff; Stokes Bluff Landing 


\section{Executive Summary}

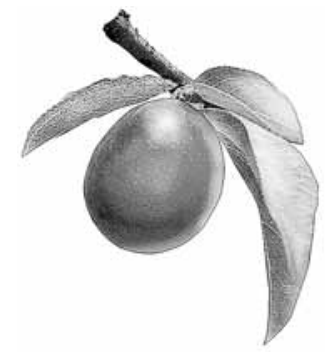

$\mathbf{T}_{D}^{h}$

he Savannah River Site Environmental Report for 2010 (SRNS-STI-2011-00059) is prepared for the U.S.

Department of Energy (DOE) according to requirements of DOE Order 231.1A, "Environment, Safety and Health Reporting," and DOE Order 5400.5', "Radiation Protection of the Public and Environment."

The annual SRS Environmental Report has been produced for more than 50 years. Several hundred copies are distributed each year to government officials, universities, public libraries, environmental and civic groups, news media, and interested individuals. The report's purpose is to

- present summary environmental data that characterize site environmental management performance

- describe compliance status with respect to environmental standards and requirements

- highlight significant programs and efforts

\section{Minimal Impact}

SRS maintained its record of environmental excellence in 2010, as its operations continued to result in minimal impact to the public and the environment. The site's radioactive and chemical discharges to air and water were well below regulatory standards for environmental and public health protection; its air and water quality met applicable requirements; and the potential radiation dose from its discharges was less than the national dose standards.

The largest radiation dose that an offsite, hypothetical, maximally exposed individual could have received from SRS operations during 2010 was estimated to be 0.11 millirem (mrem) -0.05 mrem from air pathways plus 0.06 mrem from liquid pathways. (An mrem is a standard unit of measure for radiation exposure.) The 2010 SRS dose is just 0.11 percent of the DOE allpathway dose standard of 100 mrem per year, and far less than the natural average dose of about 300 mrem per year (according to Report No. 160 of the National Council of Radiation Protection and Measurements) to people in the United States. This 2010 all-pathway dose of 0.11 mrem was about 8 percent less than the 2009 dose of 0.12 mrem.

\footnotetext{
Requirements of DOE Order 5400.5 in effect through 2010, but subsequently incorporated into and superseded by DOE Order 458.1 on February 15, 2011
}

\section{Extensive Monitoring; Documented Compliance Rate of 100 Percent}

Environmental monitoring is conducted extensively within a 2,000-square-mile network extending 25 miles from SRS, with some monitoring performed as far as 100 miles from the site. The area includes neighboring cities, towns, and counties in Georgia and South Carolina. Thousands of samples of air, rainwater, surface water, drinking water, groundwater, food products, wildlife, soil, sediment, and vegetation are collected by SRS and state authorities and analyzed for the presence of radioactive and nonradioactive contaminants.

Compliance with environmental regulations and with DOE orders related to environmental protection provides assurance that onsite processes do not impact the public or the environment adversely. Such compliance is documented in this report.

SRS had a National Pollutant Discharge Elimination System (NPDES) compliance rate of 100 percent in 2010, with zero of the 5,059 sample analyses performed exceeding permit limits - a compliance record that has been attained only one other time (2007). The NPDES program protects streams, reservoirs, and other wetlands by limiting the release of nonradiological pollution into surface waters. Discharge limits are set for each facility to ensure that SRS operations do not negatively impact aquatic life or degrade water quality. 


\section{One NOV/One NOAV}

Issued by the U.S. Environmental Protection Agency

or the South Carolina Department of Health and

Environmental Control, Notices of Violation (NOVs) or

Notices of Alleged Violation (NOAVs) are the formal regulatory notices that allege potential violations of an organization's permits, or of environmental laws or regulations. SRS received one NOV and one NOAV in 2010 - both under the Clean Air Act. 


\title{
Introduction
}

\author{
Timothy Jannik \\ Savannah River National Laboratory
}

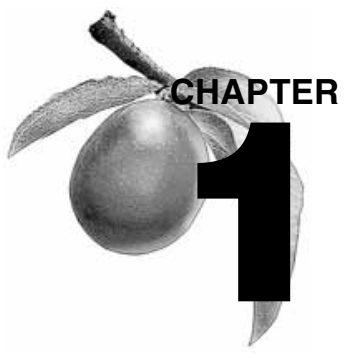

Al Mamatey

Regulatory Integration \& Environmental Services

$\mathbf{T}$

his report was prepared in accordance with U.S. Department of Energy (DOE) Order 231.1A, "Environment, Safety

and Health Reporting," to present summary environmental data for the purpose of

- characterizing site's environmental management performance

- summarizing environmental occurrences and responses reported during the calendar year

- describing compliance status with respect to environmental standards and requirements

- highlighting significant site programs and efforts

This report is the principal document that demonstrates compliance with the requirements of DOE Order 5400.5, "Radiation Protection of the Public and the Environment," and is a key component of DOE's effort to keep the public informed of environmental conditions at Savannah River Site (SRS).

\section{Missions}

SRS has four primary missions:

- Environmental Management - Cleaning up the legacy of the Cold War efforts and preparing decommissioned facilities and areas for long-term stewardship

- Nuclear Weapons Stockpile Support - Meeting the needs of the U.S. nuclear weapons stockpile through the tritium programs of the National Nuclear Security Administration (NNSA)

- Nuclear Nonproliferation Support - Meeting the needs of the NNSA's nuclear nonproliferation programs by safely storing and dispositioning excess special nuclear materials

- Research and Development - Supporting the application of science by the Savannah River National Laboratory (SRNL) to meet the needs of SRS, the DOE complex, and other federal agencies

During 2010, SRS worked to fulfill these missions and position the site for future operations. SRS continued to work with the South Carolina Department of Health and Environmental Control (SCDHEC), the Environmental Protection Agency (EPA), and the Nuclear Regulatory Commission to find and implement solutions and schedules for waste management and disposition. As part of its mission to clean up the Cold War legacy, SRS will continue to address the highest-risk waste management issues by safely storing and preparing liquid waste and nuclear materials for disposition, and by safely stabilizing any tank waste residues that remain on site.

\section{Site Location, Demographics, and Environment}

SRS, a DOE complex facility, was constructed during the early 1950 s to produce materials (primarily plutonium-239 and tritium) used in nuclear weapons. The site, which borders the Savannah River, covers approximately 310 square miles in South Carolina. Savannah River Nuclear Solutions, LLC (SRNS), assumed responsibility from Washington Savannah River Company (WSRC) for SRS Maintenance and Operations activities in 2008. Savannah River Remediation (SRR) subsequently took over the site's Liquid Waste Operations functions from WSRC in 2009.

SRS covers 198,344 acres in Aiken, Allendale, and Barnwell counties of South Carolina. The site is approximately 12 miles south of Aiken, South Carolina, and 15 miles southeast of Augusta, Georgia (figure 1-1). Based on the U.S. Census Bureau's 2010 decennial data, the population within a 50-mile radius of the center of SRS is approximately 781,060 - an increase of 9.6 percent over the 2000 population in this area. This translates to an average population density of about 104 people per square mile outside the SRS boundary, with 


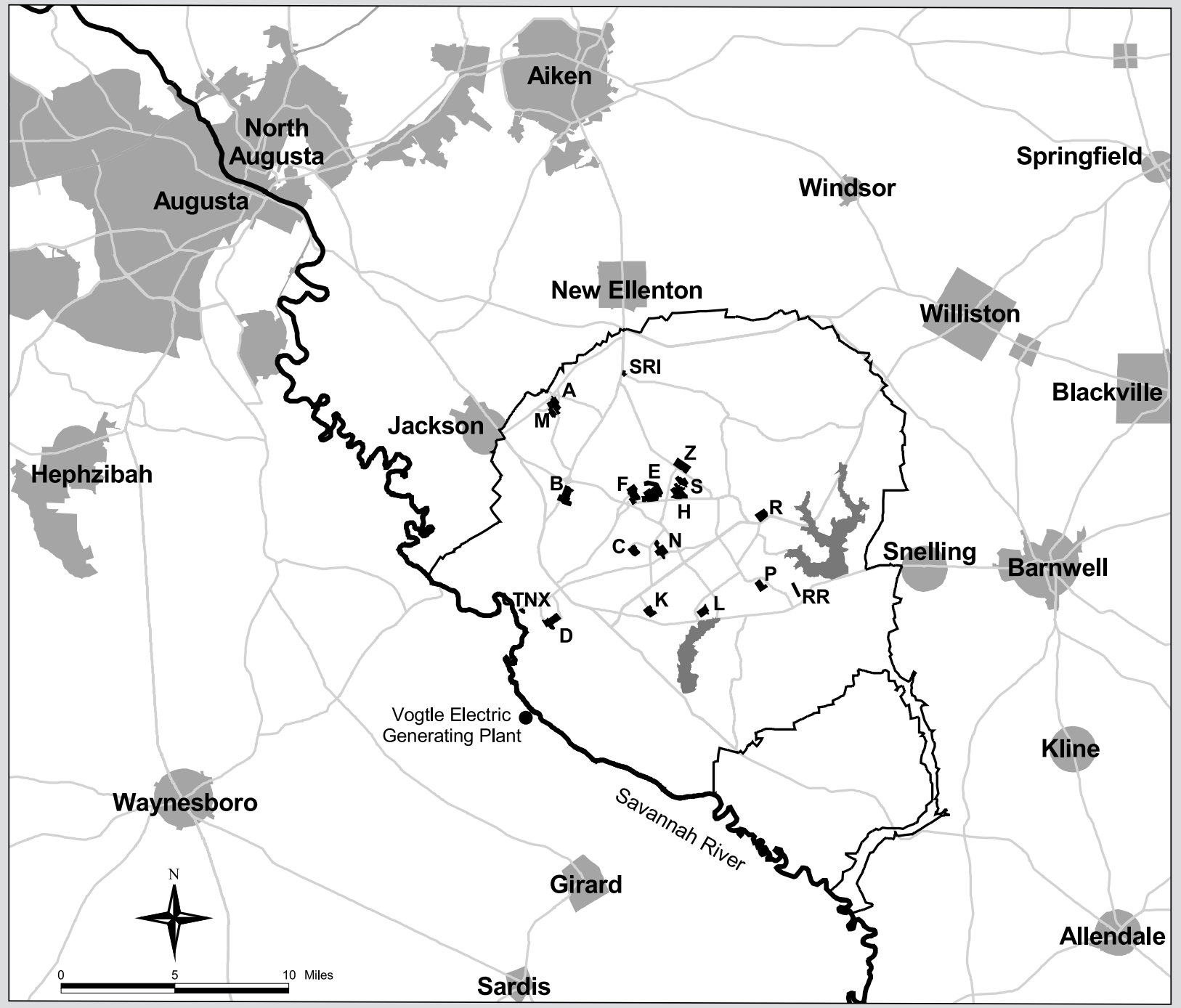

Figure 1-1 The Savannah River Site

SRNL Map

SRS is located in South Carolina, about 12 miles south of Aiken, South Carolina, and about 15 miles southeast of Augusta, Georgia. The Savannah River flows along a portion of the site's southwestern border. The capital letters within the SRS borders identify operations areas referenced throughout this report.

the largest concentration in the Augusta metropolitan area.

\section{Water Resources}

SRS is bounded on its southwestern border by the Savannah River for about 35 river miles and is approximately 160 river miles from the Atlantic Ocean. The nearest downriver municipal facility that uses the river as a drinking water source (Beaufort-Jasper Water and Sewer Authority's Purrysburg Water Treatment Plant) is located approximately 90 river miles from the site. The river also is used for commercial and sport fishing, boating, and other recreational activities.
According to officials with SCDHEC and the Georgia Department of Natural Resources, there are no known large-scale uses of the river for irrigation by farming operations downriver of the site.

The groundwater flow system at SRS consists of four major aquifers. Groundwater generally migrates downward as well as laterally_eventually either discharging into the Savannah River and its tributaries or migrating into the deeper regional flow system. SRS groundwater is used on site both for processes and for drinking water. 


\section{Geology}

SRS is located on the southeastern Atlantic Coastal Plain, which is part of the larger Atlantic Plain that extends south from New Jersey to Florida. The center of SRS is approximately 25 miles southeast of the geological Fall Line that separates the Coastal Plain from the Piedmont. Characterization of regional earthquake activity is dominated by the catastrophic Charleston, South Carolina, earthquake of August 31, 1886 (est. magnitude of 7.0 on the Richter scale). With nearly three centuries of available historic and contemporary seismic data, the Charleston/Summerville area remains the most seismically active region of South Carolina - and the most significant seismogenic region affecting SRS. Ongoing studies by University of South Carolina seismologists suggest a recurrence interval of 500-600 years for magnitude 7.0 or greater earthquakes (similar to the 1886 event) near Charleston. Earthquake activity occurring within the upper Coastal Plain of South Carolina, where the majority of SRS is located, is characterized by occasional small shallow events associated with strain release near small-scale faults and intrusives. Levels of seismic activity within this region are very low, with magnitudes or sizes generally less than or equal to 3.0

\section{Land and Forest Resources}

About 90 percent of SRS land area consists of natural and managed forests, which are planted, maintained, and harvested by the U.S. Department of Agriculture Forest Service-Savannah River. The site contains four major forest types: mixed pine-hardwoods, sandhills pine savanna, bottomland hardwoods, and swamp floodplain forests. More than 345 Carolina bays exist on SRS. Carolina bays are relatively small, shallow depressions that provide important wetland habitat and refuge for many plants and animals.

\section{Animal and Plant Life}

The majority of SRS is undeveloped; only about 10 percent of the total land area is developed or used for mission-oriented facilities. The remainder is maintained in healthy, diverse ecosystems. SRS is home to about 1,500 species of vascular and nonvascular plants, more than 100 species of reptiles and amphibians, some 50 species of mammals, and nearly 100 species of fishand provides habitat for more than 250 species of birds. Nearly 600 species of aquatic insects can be found in SRS streams and wetlands. The site also provides habitat for a number of protected species - including the wood stork, the red-cockaded woodpecker, the pondberry, and the smooth coneflower (all federally listed as endangered) - and at least 40 plant species of state or regional concern.

\section{Primary Site Activities Nuclear Materials Stabilization Project}

In the past, the SRS separations facilities processed special nuclear materials and used fuel from site reactors to produce materials for nuclear weapons and isotopes for medical and National Aeronautics and Space Administration applications. The end of the Cold War in 1991 brought a shift in the mission of these facilities to stabilization of nuclear materials from onsite and offsite sources for safe storage or disposition. F Canyon, one of the site's two primary separations facilities, was deactivated in 2006. The other facility, $\mathrm{H}$ Canyon, continues to operate, and an important part of its mission is the conversion of weapons-usable, highly enriched uranium to low-enriched uranium for use in the manufacture of commercial reactor fuel, a key function of the nation's nuclear nonproliferation program.

\section{Used Nuclear Fuel Storage}

SRS's used nuclear fuel facilities receive and store fuel elements from a variety of foreign and domestic reactors. The mission of the UNF program is to safely and cost-effectively receive and store used fuel elements from foreign and domestic research reactors-pending disposition-in support of nuclear research and the Global Threat Reduction Initiative.

\section{Tritium Processing}

SRS tritium facilities are designed and operated to supply and process tritium, a radioactive form of hydrogen gas that is a vital component of nuclear weapons. These facilities are part of the National Nuclear Security Administration's Defense Programs operations at SRS.

\section{Waste Management Liquid Waste Operations}

SRR continued to manage the SRS Liquid Waste Operations facilities in 2010, and to support the integrated high-activity waste program and tank closure process. This work included dispositioning waste from tanks located in the site's F Area and H Area tank farms. Dispositioning of the waste included operation of the Defense Waste Processing Facility, which immobilizes high-level waste in glass; the Saltstone Production and Disposal Facilities, which process and dispose lowactivity salt waste in a grout form; and the salt waste processing facilities, known as the Actinide Removal 
Process/Modular Caustic Side Solvent Extraction Unit, which decontaminate the salt waste and send it to Saltstone.

A detailed description of the site's 2010 Liquid Waste Operations activities can be found on the CD accompanying this report.

\section{SRS manages}

- the large volumes of radiological and nonradiological waste created by previous operations of the nuclear reactors and their support facilities

- $\quad$ newly generated waste created by ongoing site operations

Although the primary focus is on safely managing the radioactive liquid waste, the site also must handle, store, treat, dispose of, and minimize solid waste resulting from past, ongoing, and future operations. Solid waste includes hazardous, low-level, mixed, sanitary, and transuranic wastes. More information about radioactive liquid and solid wastes is included on the CD housed inside the back cover of this report.

\section{Area Completion Projects}

Past operations at SRS have resulted in the release of hazardous and radioactive substances to soil and groundwater, with contamination levels exceeding regulatory thresholds. The mission of Area Completion Projects (ACP) personnel is to deactivate and decommission contaminated facilities and remediate (if necessary) soils, groundwater, surface water, and sediments to levels that comply with established regulatory thresholds and that protect human health and the environment.

Numerous technologies have been pioneered to increase the effectiveness of ACP's remediation efforts and to reduce hazardous risk across the site. ACP utilizes a Green Remediation approach to reduce greenhouse gas emissions and other negative environmental impacts that might occur during characterization or remediation of hazardous waste sites. Green Remediation is the practice of (1) considering all the environmental effects of remedy implementation and (2) incorporating options to minimize the environmental footprints of cleanup actions. Natural remedies used at SRS include phytoremediation (augmented natural vegetative processes), bioremediation (augmented naturally occurring microbial processes), and natural remediation (natural processes to address contamination). These technologies are proving to be a cost-efficient means of reducing risk to human health and the environment, and have been successful in expediting cleanups.

Cleanup decisions are reached through implementation of a core team process with EPA Region 4 and SCDHEC. In reaching such decisions, the public's and stakeholders' (such as the Citizens Advisory Board) input is solicited and considered. ACP uses a streamlined cleanup strategy to accelerate work and reduce overall lifecycle costs. During 2010, ACP completed final remediation of M Area, the second large former industrial area on SRS (T Area cleanup was completed in 2006).

More information about ACP's 2010 operations is included on the $\mathrm{CD}$ accompanying this report.

\section{Effluent Monitoring and Environmental Surveillance}

The general purpose of the effluent monitoring and environmental surveillance programs is to

- demonstrate compliance with applicable environmental regulations, DOE orders, and commitments made in environmental documents

- $\quad$ manage SRS effluents and their treatment and control practices

- $\quad$ identify, characterize, quantify, trend, and report the effects (if any) of SRS operations on the public and on the environment in and around the site

SRS sampling locations, sample media, sampling frequency, and types of analysis are selected based on environmental regulations, exposure pathways, public concerns, and measurement capabilities. The selections also reflect the site's commitment to (1) safety; (2) protecting human health; (3) reducing the risks associated with past, present, and future operations; (4) improving cost effectiveness; and (5) meeting regulatory requirements.

\section{Releases}

Releases to the environment of radioactive and nonradioactive materials come from legacy contamination as well as from ongoing site operations. For instance, contaminated, shallow groundwater-a legacy - flows slowly toward and into onsite streams and swamps, and eventually into the Savannah River. During routine day-to-day site operations, liquid discharges and air emissions release contaminants to the environment. SRS uses the "as low as reasonably achievable" (ALARA) concept to manage these releases. 


\section{Pathways}

The routes that contaminants can follow to enter the environment and then reach people are known as exposure pathways. A person potentially can be exposed when he or she breathes the air, consumes locally produced foods and milk, drinks water from the Savannah River, eats fish caught from the river, or uses the river for recreational activities such as boating, swimming, etc.

One way to determine if contaminants from the site have reached the environment is through environmental monitoring. The site gathers thousands of air, water, soil, sediment, food, vegetation, and animal samples each year. The samples are analyzed for contaminants released from site operations, and the potential radiation exposure to the public is assessed. Samples are taken at the points where materials are released from (1) the facilities (effluent monitoring) and (2) the environment itself (environmental surveillance). SCDHEC also had a program in place during 2010 to monitor the environment in and around SRS, as well as near the City of Savannah (for tritium in the Savannah River).

\section{Research and Development Savannah River National Laboratory}

SRNL is SRS's applied research and development laboratory. SRNL "puts science to work" to create and implement practical, high-value, cost effective technology solutions in the areas of Environment Management, National and Homeland Security, and Energy Security. SRNL provides technical leadership and key support for future SRS missions. More information can be obtained by contacting SRNL at 803-725-2854, or by viewing the facility's website at http://shrine.srs.gov/html/srnl/index.html.

\section{Savannah River Ecology Laboratory}

The Savannah River Ecology Laboratory (SREL) is a research unit of The University of Georgia that has been conducting ecological research at SRS for more than 55 years. The facility's overall mission is to acquire and communicate knowledge of ecological processes and principles. SREL conducts fundamental and applied ecological research, as well as education and outreach programs, under a cooperative agreement with DOE. More information can be obtained by contacting SREL at 803-725-2472, or by viewing the laboratory's website at http://www.srel.edu/. Also, SREL's technical progress report for 2010 is included on the $\mathrm{CD}$ accompanying this document.

\section{USDA Forest Service-Savannah River}

The USDA Forest Service-Savannah River (USFS-SR), a unit within the Southern Region of the U.S. Department of Agriculture, manages approximately 170,000 acres of natural resources at SRS. USFS-SR operates under an interagency agreement with DOE-Savannah River Operations Office and implements the $S R S$ Natural Resources Management Plan for a variety of natural resources. More information can be obtained by contacting USFS-SR at 803-725-0006, or by viewing the USFS-SR website at www.fs.usda.gov/savannah river. Also, USFS-SR's 2010 report is included on the $\mathrm{CD}$ accompanying this document.

\section{Savannah River Archaeological Research Program}

The Savannah River Archaeological Research Program (SRARP) provides continued cultural resource management guidance to DOE to ensure fulfillment of compliance commitments. SRARP also serves as a primary facility for the investigation of archaeological research problems associated with cultural development within the Savannah River valley, using the results to help DOE manage more than 1,300 known archaeological sites at SRS. More information can be obtained by contacting SRARP at 803-725-3724, or by viewing the SRARP website at http://www.srarp. org. Also, SRARP's 2010 report is included on the CD accompanying this document. 



\title{
Environmental Management System
}

\author{
Michael E. Roper \\ Regulatory Integration \& Environmental Services
}

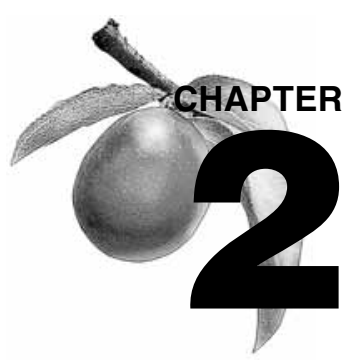

C ompliance with environmental statutory and other legal regulatory requirements is a fundamental responsibility of all federal agencies. In 2010, Savannah River Site (SRS) continued to meet or exceed performance expectations with respect to the management of environmental protection activities related to air, water, land, and other important resources.

This chapter focuses on the integration of numerous environmental requirements mandated by existing statutes, regulations, and policies as implemented through the SRS Environmental Management System (EMS). All contractor requirements mandated by U.S. Department of Energy (DOE) Order 450.1A, "Environmental Protection Program," are considered in the site's Integrated Safety Management System (ISMS) structure.

A management system is a tool established by an organization to manage its operations and activities in the pursuit of its policies and goals. In the case of the EMS, it is not a stand-alone environmental program or a data management program. Implementation of the EMS enables SRS to clearly identify and establish environmental goals, develop and implement plans to meet the goals, determine measurable progress toward the goals, and take steps to ensure continuous improvement.

Executive Order (EO) 13423, "Strengthening Federal Environmental, Energy, and Transportation Management," signed January 24, 2007, directs each federal agency to use an EMS as the management framework to implement, manage, measure, and continually improve upon sustainable environmental, energy, and transportation practices. EO 13423 mandates that the EMS shall include corresponding federal agency-specific objectives and targets to meet goals in (among others) energy efficiency and reduction of greenhouse gas emissions, use of renewable energy, water conservation, fleet management, electronics stewardship and purchasing, reduction in the use of toxic and hazardous chemicals and materials, and pollution and waste prevention/recycling.

DOE issued DOE Order 450.1A in June 2008 to delineate responsibilities for carrying out the requirements of EO 13423. This included a requirement that in the initial year of implementation (2009) and every third year thereafter, an independent external audit must be performed to ensure compliance with the order and conformance with the 17 elements of the International Organization for Standardization (ISO) 14001 Standard, "Environmental Management System." The initial external audit of SRS's EMS - conducted April 28 to May 1, 2009-concluded that the EMS conformed to both the order and the ISO standard. Savannah River Nuclear Solutions (SRNS) — as the site's maintenance and operations (M\&O) contractorcompleted actions necessary to enable the "declaration" of conformance in June 2009.

EO 13514, "Federal Leadership in Environmental, Energy, and Economic Performance," was signed by President Obama in October 2009. As of the end of 2010, DOE had not revised its applicable orders to correspond with EO 13514. As such, the Contractor Requirements Documents (CRDs) of the respective DOE orders are pending modification to reflect the additional requirements. Pending inclusion of the new EO requirements within applicable contracting documents, site contractors and tenant agencies continued to support goals and objectives of the order in 2010 to the extent permitted by approved contracts and agreements.

\section{SRS EMS Implementation}

The EMS at SRS is implemented by multiple contractors using documents, programs and strategies tailored to organization-specific resources. DOE-SR oversees the implementation of each strategy to ensure a consistent and integrated site program. The implementation strategy for SRNS, as the M\&O contractor, and Savannah River Remediation (SRR), managing 
Liquid Waste Operations (LWO), is documented in the "Environmental Management System Description Manual" (G-TM-G-00001). This manual can be viewed via the following internet link: http://irmsrv02.srs.gov/ general/pubs/envbul/documents/ems_manual.pdf.

Additional SRS contractor or tenant organization documents describing EMS implementation strategies include the following:

- Wackenhut Services Incorporated-Savannah River Site (WSI-SRS), Procedure Number 1-05

- Parsons - Environmental Management System Program, Q-PLN-J-0100
- Shaw AREVA MOX Services - Mixed Oxide Fuel Project Integrated Environment, Safety and Health Plan, DCS01-AHS-DS-PRG-H-40003-4

\section{Integration of the SRS EMS within ISMS}

Figure 2-1 depicts the processes by which environmentally impacting activities performed at SRS are integrated into the ISMS. This approach, whereby environmental regulatory requirements are rolled into implementing programs and procedures, is followed to varying degrees within all SRS organizations to reflect specific work scope, resources, and potential for environmental impact.

\section{Integration of SRS EMS into ISMS}

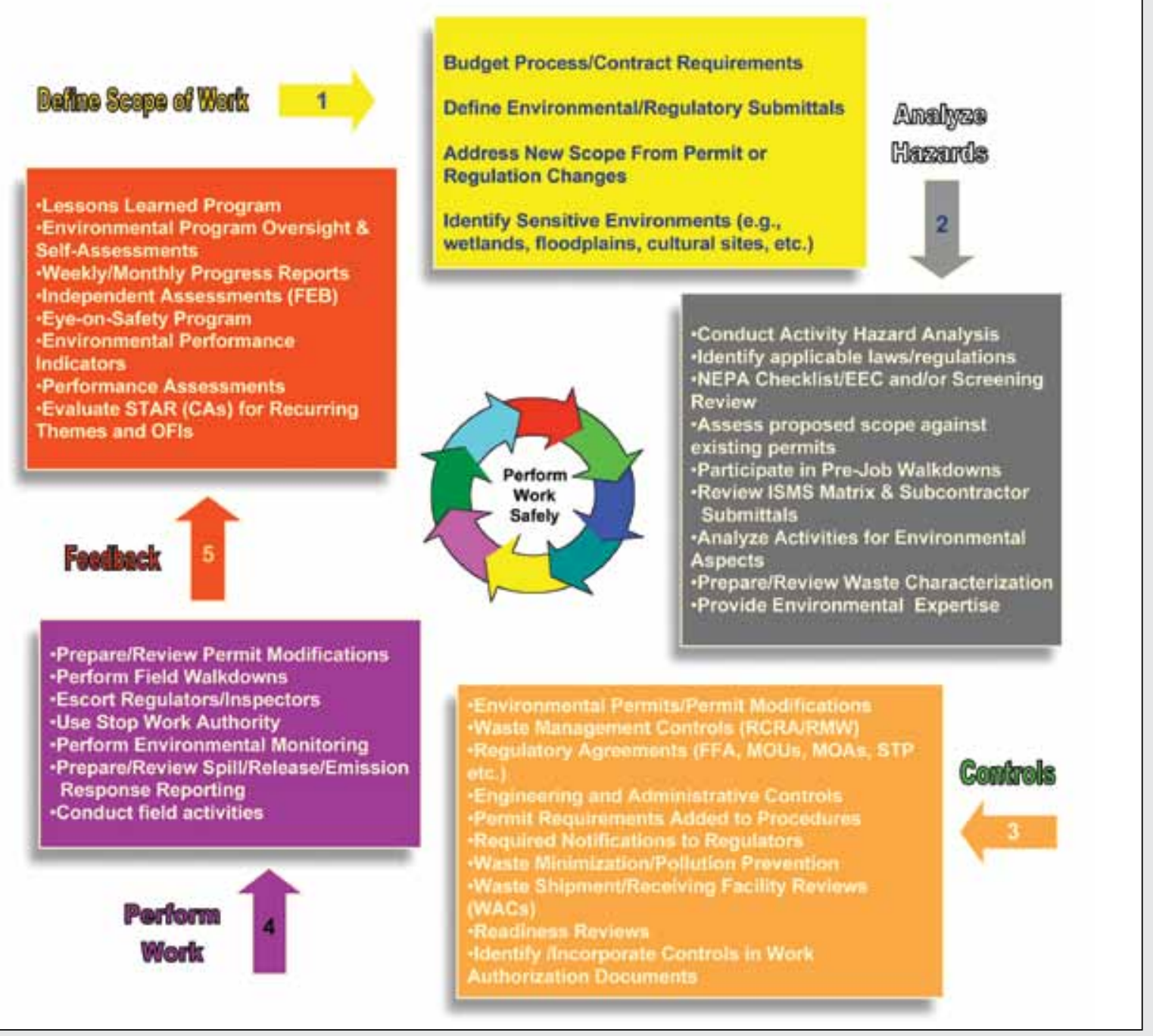

Figure 2-1 Environmental Management System Integration 


\section{Environmental Policy}

The SRS Environmental Policy is a statement of the site's intent to implement sound stewardship practices that protect the air, water, land, and other natural and cultural resources impacted by SRS operations. The policy's objective is to establish a consistent sitewide approach to environmental protection through the implementation of an EMS as integrated within the site's comprehensive ISMS. The SRS EMS provides for the systematic planning, integrated execution, and evaluation of site activities for (1) public health and environmental protection, (2) pollution prevention (P2) and waste minimization, (3) compliance with applicable environmental protection requirements, and (4) continuous improvement of the EMS.

The policy is updated, published, and communicated throughout the site annually-and is posted to the externally accessible SRS website to foster further dissemination to the surrounding community. The policy letter is posted at http://irmsrv02.srs.gov/general/pubs/ envbul/documents/env_mgt_sys_policy.pdf.

\section{Environmental Aspects and Impacts}

Determining environmental aspects (elements of activities, products, processes, and services that could have a significant impact on the environment) is critical to the EMS process. It equates to analyzing hazards via the ISMS review protocol. Identifying the SRS environmental aspects is not the end of the process. SRS personnel must evaluate work activities, whether routine or unusual, to determine whether the aspects are impacted by the work activity. This leads to the development and implementation of controls necessary to mitigate the potential that the action will adversely affect the environment. Environmental aspects (as well as goals and targets) are reviewed by senior management during EMS status meetings to keep the aspects current.

As part of the SRS Environmental Evaluation Checklist (EEC) process, the method by which environmental aspects and impacts are identified, evaluated for significance (using a "scoring worksheet"), reviewed by management for validation and determination of mitigative/corrective actions, and documented (including significance determinations) is described in the "Environmental Management System Description Manual."

\section{Legal and Other Requirements}

Regulatory and DOE environmental program and compliance requirements are contained in the site's Standards/Requirements Identification Document
(S/RID), which provides a crosswalk between regulatory and DOE source requirements and the corresponding SRS implementing documents. The S/RID encompasses requirements to protect the environment and the health of the public and employees, including policy management, permitting, monitoring, surveillance and inspections, control standards, pollution prevention, record keeping and reporting, notifications, and key interfaces. Additional information on SRS environmental compliance is contained in chapter 3 ("Compliance Summary") of this annual SRS Environmental Report.

\section{Objectives, Targets, and Programs}

Environmental targets are established, implemented, and maintained consistent with and in support of DOE environmental objectives, which include increasing energy efficiency, reducing greenhouse gases (GHG), using renewable energy, water conservation, pollution prevention initiatives, petroleum conservation and alternative fuel use, and incorporating sustainable building standards. Objectives and targets are established to 1) achieve full compliance with applicable environmental requirements, 2) devote resources to specific pollution prevention initiatives, and 3) ensure responsible stewardship of natural and cultural resources at SRS.

The targets and goals are developed and endorsed by senior managers responsible for each of the functional areas associated with the objectives. Once approved, lead responsibility for achieving the goals and targets is assigned to a specific organization. Lead points of contact are designated and execution schedules are established and tracked. Annual targets and corresponding performance measurements that reflect progress are posted to the internal EMS website, and are available upon request.

Seven specific objectives and targets encompassing seven significant environmental aspects were established for FY10. The targets for each objective were either met or exceeded through FY10. Data table 2-1 (see "SRS Environmental Data/Maps" on the CD accompanying this report) summarizes objectives/targets, actions taken, and progress/success. A summary of the table (2-1) can be found on page 2-4.

\section{Competence, Training, and Awareness}

The purpose of the SRS environmental training program is to ensure that personnel whose actions could have environmental consequences are properly trained and made aware of their responsibilities to 
Table 2-1 FY10 SRS EMS Goals (Summary)

EMS Goal/Objective "Stoplight"

Status

Site energy intensity increased slightly in FY10 versus FY09 $(3.3 \%)$. This is due primarily to major weather impacts, increased ARRA work/staffing, and across-the-board increases

Reduce building energy intensity (BTU/GSF) by $3 \%$ annually or by $30 \%$ by the end of FY15

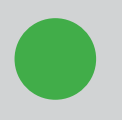
in production/mission energy use. In spite of the 3.3\% FY10 increase, the site is ahead of the overall energy intensity reduction goal of a $30 \%$ reduction during the period $\mathrm{FY} 03$ to FY15. A summary report detailing how to comply with HPSB requirements in existing buildings was issued to DOE-SR in September 2010. Construction on three new biomass facilities proceeded well in 2010.

Purchase $3 \%$ of facility electrical energy from renewable sources, $50 \%$ of which must have been placed into service after $1 / 1 / 1999$

Construction of the new Biomass Cogeneration Facility near $F$ Area remained on schedule. Construction of the $\mathrm{K}$ Area and $\mathrm{L}$ Area biomass boilers was completed in FY10.

Reduce water consumption by $2 \%$ annually or by $16 \%$ by the end of FY15

The C Area-to-K Area domestic water supply line project was completed in February 2010. K Area well pumping was terminated as planned. As a result, site combined domestic and process water use was reduced by $11 \%$ versus FY 2009. This reduction would have been greater if not for associated ARRA/ stimulus impacts.

1) In FY10, SRS avoided generating 838 cubic meters of radioactive and hazardous waste, exceeding the FY10 goal by $110 \%$. Twenty-three (23) projects contributed to the avoidance efforts, resulting in a cost avoidance of $\$ 1.5$ million.

Reduce the use of hazardous materials and toxic chemicals

2) The FY10 routine sanitary waste recycle rate was $38.8 \%$.

3) The Chemical Management Center redistributed 84,773 pounds of excess chemicals in FY10, avoiding $\$ 1.2$ million in waste and acquisition costs.

Construct or renovate buildings in accordance with sustainability strategies; Incorporate sustainable practices in $15 \%$ of existing federal capital asset building inventory by 2015

A 62-page summary report detailing how to comply with HPSB requirements in existing buildings was issued to DOE-SR in September 2010. The SRS Ten-Year Site Plan included an overview of HPSB efforts.

SRS petroleum consumption increased by nearly $21 \%$ (combined gasoline and diesel) in FY10 versus FY09-due primarily to an increase in ARRA/stimulus staffing and scope. In addition, DOE-

Reduce consumption of petroleum products by $2 \%$ annually through FY15 $\mathrm{HQ}$ mandated use of approximately 60 hybrid gasoline vehicles at SRS, which also negatively impacted this metric. Hybrids cannot use blended E85 fuel; rather, they require unblended gasoline. However, the site is on track to meet the overall goal, having realized a $10 \%$ petroleum reduction through FY10 when compared to the FY05 baseline year.

Increase fleet nonpetroleumbased fuel consumption by $10 \%$ annually

During the past 10 years, SRS has increased use of E85 fuel by $350 \%$, far exceeding the end-state goal of a $10 \%$ annual increase.

competently protect the environment, workers, and the public. All SRS employees have been informed of EMS requirements, especially those whose responsibilities include environmental protection and regulatory compliance. All employees are responsible for supporting and complying with EMS programs and processes. This includes complying with legal requirements, understanding pollution prevention/waste minimization techniques, and continuously improving operating practices to enhance and protect the site's 
workers, the environment, and the public.

General environmental awareness training is provided to all SRS employees. Specialized training opportunities are developed by and offered through a centralized training organization that relies heavily on the functional-area subject matter expertise within the environmental organization for the development and presentation of environmental and waste management curricula.

From a process improvement perspective, the environmental training program underwent a major revision in 2010 to more clearly define and clarify evolving roles, responsibilities, authority, and accountability (R2A2) for environmental personnel. Training requirements to support applicable R2A $2 \mathrm{~s}$ were identified, evaluated, and documented. Training plans were developed for all managerial, professional, and subject matter expert positions, and qualification records were developed for technician positions. An existing automated tracking mechanism was leveraged to facilitate management, supervisory, and employee awareness of progress toward achieving and maintaining requisite training expertise.

Regularly scheduled classes in the environmental training program cover such topics as Environmental Laws and Regulations, Hazardous Waste Worker Responsibilities, Hazardous and Radiological Waste Characterization, Management of Polychlorinated Biphenyls, and Environmental Compliance Authorities. More than 60 environmental program-related training courses are listed in the site training database, and individual organizations schedule and perform other facility-specific, environment-related training to ensure that operations and maintenance personnel, as well as environmental professionals, have the knowledge and skills to perform work safely and in a manner that protects the environment in and around SRS.

\section{Resources, Roles, and Responsibilities}

All SRS employees have specific roles and responsibilities in key areas, including environmental protection. Environmental and waste management technical support personnel assist site operating organizations with developing and meeting their environmental responsibilities. SRS maintains detailed manuals on resources, roles, responsibilities, and authority to assist employees in performing their duties.

\section{Communications}

SRS continues to maintain and improve internal and external communications on environmental issues. Many policies and procedures guide communications at the site, ranging from the general site policy to forms and techniques addressed in facility-specific procedures. Additionally, SRS solicits input from interested parties such as community members, activists, elected officials, and regulators. The SRS Citizens Advisory Board provides advice and recommendations to DOE on environmental compliance, remediation, waste management, facility decommissioning, and related issues. Ex-officio members from DOE-SR, the U.S. Environmental Protection Agency (EPA) Region 4, the South Carolina Department of Health and Environmental Control (SCDHEC), and the Georgia Department of Natural Resources participate in board activities. At the core of the communication and community involvement programs are the SRS Environmental Policy (previously discussed) and the SRS Federal Facility Agreement Community Involvement Plan (WSRC-RP-96-120, Rev 5, July 2006), which is an administrative record file available for viewing at any designated SRS Public Reading Room. The ultimate goal of environmental communications is to improve stakeholder understanding and the site's overall environmental performance.

Additional forums for the dissemination of information associated with environment issues include the Senior Environmental Managers Council (SEMC), comprised of senior-level environmental managers (from all SRS contractors) who share information on environmental concerns, regulatory matters, SRS operational issues, and upcoming changes to improve the SRS environmental compliance program; DOESR's Environmental Quality Management Division (EQMD), which convenes regular meetings with SRS contractors and the DOE environmental oversight staff to discuss issues relevant to environmental protection and compliance; the SRS Regulatory Integration Team (SRIT), consisting of DOE-SR, EPA Region 4 , and SCDHEC representatives who address issues that are cross-cutting and require high-level agency collaboration; and the Challenges, Opportunities, and Resolution (COR) Team, consisting of regulatory compliance representatives of SRNS and other major SRS contractors who discuss (1) emerging compliance or implementation challenges and (2) opportunities to develop and coordinate resolutions.

\section{Operational Controls}

Operational controls help ensure that environmental policy-related activities of regulatory compliance, pollution prevention, and continuous improvement 
by SRS management are in place and implemented. Consistent with both the policy and the objectives/ targets, operations activities are identified, planned, and executed to ensure that they are carried out within appropriate controls. From an environmental protection perspective, one of the more significant operational controls is the consistent use of the EEC process previously mentioned. As each new process/activity or proposed revision/modification to an existing operation is considered, preparation of an EEC is initiated for that activity to ensure that environmentally impacting considerations are factored into final decisions.

\section{Emergency Preparedness and Response}

Emergency plans are established, implemented, and maintained as documented in the SRS Emergency Plan and other references. The Emergency Plan specifies procedures to facilitate the identification of emergency situations and accidents with the potential to impact the environment, and provides definitions of appropriate responses and reporting criteria.

SRS emergency plans and programs include occurrences categorized as environmental emergencies. Procedures and documents that guide the Emergency Preparedness Process are specified in the EMS Description Manual (internet link previously provided).

\section{Monitoring and Measurement}

Monitoring and measurement means that the environmental impacts of SRS operations are sampled and examined regularly. This includes effluent (radiological and nonradiological), compliance, performance, and equipment/facility monitoring (e.g., calibration of instruments). Numerous procedures and processes, many of them listed in the EMS Description Manual, support this requirement. Additional information on environmental monitoring, environmental surveillance, and groundwater monitoring is contained in chapters 4 ("Effluent Monitoring”), 5 (“Environmental Surveillance”), and 7 (“Groundwater"), respectively, of this site environmental report.

\section{Evaluation of Compliance}

Specific environmental laws and regulations are evaluated and assessed on a program- or facility-specific basis. SRS has established a process for periodically evaluating its compliance with relevant environmental regulations. This process is captured primarily in the S/RID, the Source and Compliance Document (SCD-4), and various site implementing manuals and procedures. Compliance evaluations and assessments are integrated into operating organizations' environmental, safety, and health inspection process, which is performed in a prioritized fashion by a team of experts - including one on environmental regulatory issues. Periodically, environmental support organizations conduct regulatory assessments in selected topical areas to verify compliance. Finally, external regulatory agencies and/or technical experts may perform independent compliance audits. Additional information on environmental compliance is contained in chapter 3 of this site environmental report.

\section{Nonconformance; Corrective and Preventive Actions}

Nonconformance and corrective and preventive actions include EMS nonconformance as a part of the site's quality assurance (QA) program. The application of QA procedures, therefore, supports the total EMS process. For example, use of the nonconformance report form applies to environment-related equipment, instruments, facilities, and procedures. Also, instances of nonconformance identified by assessments and evaluations are recorded and dispositioned according to established procedures. Additional QA information is contained in chapter 8 ("Quality Assurance") of this environmental report.

\section{Control of Records and Documents}

The identification, maintenance, and disposition of environmental records and documents, required by environmental regulations and DOE directives, are reflected in the SRS EMS. The site's records management program satisfies the requirement for environmental records. Specific documentationsuch as records of correspondence with regulatory agencies, environmental training records, and EECs - is addressed in department-level procedures. For example, Regulatory Integration and Environmental Services maintains records of correspondence with regulatory agencies. Environmental training records are maintained by the line organization requiring and conducting the training, as well as by the SRS Training Department. EECs completed by facilities for specific activities are forwarded to and maintained by SRNS. A listing of the significant records and document management procedures in use at SRS is provided in the EMS Description Manual.

\section{Internal Audits}

SRS audits are incorporated into the DOE and 
contractor assessment programs to verify that the site's EMS is functioning as intended. Performance assessments include performance objectives and criteria for management system review. Self-assessments are conducted in accordance with senior managementapproved assessment plans. SRS utilizes a Facility Evaluation Board to conduct independent performancebased assessments of site programs to satisfy contractual and regulatory obligations.

\section{Management Review}

The SRS EMS Policy requires periodic evaluations of EMS effectiveness. Guidelines are intended to focus the management review on continuous improvement. Oversight of SRS's annual EMS review is the responsibility of DOE-SR's EQMD.

Senior management reviews the EMS to ensure its continuing suitability, adequacy, and effectiveness. Reviews include assessing (1) opportunities for improvement and (2) the need for changes to the EMS. Records of management reviews are retained in accordance with applicable procedures.

Consistent with declarations contained in the SRS Environmental Policy letter and the EMS Description Manual, senior management reviews of improvement opportunities and progress toward sustainable program goals are required. Implementation of this requirement is demonstrated via (1) numerous management forumsincluding those conducted by the SEMC, EQMD, SRIT, and the COR Team - and (2) periodic departmental/ project performance reviews and reports.

\section{Sustainability Accomplishments EMS Implementation}

In accordance with the requirements of DOE Order 450.1A, an audit of the EMS was conducted by a qualified outside party, culminating in a June 23, 2009 , “declaration of conformance." Along with the identification of five noteworthy practices, a formal corrective action plan was developed to address one minor nonconformance, three opportunities for improvement, and two observations. All corrective actions were entered into the site commitment tracking system. From that EMS audit (and as reported in the 2009 site environmental report), the final open action item was closed during the 2010 reporting period, resolving the process whereby significant environmental aspects are evaluated. A formal process was developed, documented in the EMS Description Manual and implemented via a revision to the EEC. As previously noted, the EEC is an automated tool for documenting the evaluation of environmental impacts of proposed site operations.

\section{Pollution Prevention / Waste Minimization}

SRS's primary objective with respect to pollution prevention ( $\mathrm{P} 2$ ) and waste minimization is to prevent or reduce pollution at its source whenever feasible. In FY10, the site's 10-percent waste reduction goal for hazardous and radioactive waste equated to 399 cubic meters, based on forecast generation rates. Using a modified pollution prevention opportunity assessment process (referred to as Pollution Prevention Activity Forms - PPAF) approved by DOE-SR, 23 P2 projects were documented and approved for credit, resulting in 838 cubic meters of hazardous and radioactive waste avoidance and/or diversion. This exceeded the site goal by 110 percent while avoiding more than $\$ 1.5$ million in labor, materials, and waste management costs. Data table 2-2 (see "SRS Environmental Data/Maps" on the CD accompanying this report) summarizes FY10 pollution prevention and waste minimization contributions. A summary of the table (2-2) can be found on page 2-8.

Concurrently, SRS annually establishes a recycle performance target for its routine sanitary waste stream. A routine sanitary waste recycle target of 35 percent was established for FY10, with a contract stretch goal of more than 40 percent. SRS documented a recycle rate of 38.8 percent for this stream, equating to 1,022 metric tons of routine sanitary waste diverted to recycle markets. SRS diverted 594 metric tons of shredded wood waste, 1,346 metric tons of scrap metal, and 103 metric tons of scrap furniture. Additionally, the Chemical Management Center (CMC) distributed for re-use more than 84,773 pounds of chemicals in FY10, thus avoiding more than $\$ 1.2$ million in chemical acquisition and waste management costs.

\section{Energy Intensity}

With regard to the current DOE directive to meet or exceed a 30-percent reduction in energy intensity (energy consumption per gross square foot of building space, including industrial and laboratory facilities) by FY15 compared to the FY03 baseline year, SRS is on track to meet or exceed the 30-percent goal, having realized a 20.6-percent decrease from FY03 through FY10. The 20.6-percent decrease factors in an increase of 3.3 percent from FY09 to FY10, which reflects major regional weather impacts, increased American Reinvestment \& Recovery Act (ARRA) work and staffing levels, and across-the-board increases in production and mission-support energy use during the period. As SRS's Mixed Oxide (MOX) Fuel Fabrication Facility and Salt Waste Processing Facility become operational, the site's efforts to meet the energy intensity 
Table 2-2 2010 SRS Pollution Prevention Activities (Summary)

\begin{tabular}{|c|c|c|}
\hline Description & Waste Type & Life Cycle Savings \\
\hline Culvert Opening Area Cleanup Waste & Mixed Low-Level Waste (LLW) & $\$ 43,520$ \\
\hline Reuse of Asbestos Gaskets from K Area & LLW & $\$ 848$ \\
\hline Rollback 105-L 910 Fan Room & LLW & $\$ 21,330$ \\
\hline $\begin{array}{l}\text { Modular Caustic-Side Solvent Extraction Unit (MCU) } \\
\text { Debris to Seven Springs Landfill Avoids LLW }\end{array}$ & LLW & $\$ 200,550$ \\
\hline Segregation and Recycling of Circuit Boards & Hazardous Waste (HW) & $(\$ 770)$ \\
\hline $\begin{array}{l}\text { SmartPlant Foundation (SPF) Tuff Tank (Polyethylene } \\
\text { Tank for Liquid Storage and Transport) Frames to Sanitary } \\
\text { Special Waste }\end{array}$ & LLW & $\$ 1,172$ \\
\hline $\begin{array}{l}\text { Polychlorinated Biphenyls (PCB) Waste Reduction - } \\
\text { K Area Complex (KAC) Shuffler Project }\end{array}$ & $\begin{array}{l}\text { Mixed Toxic Substances } \\
\text { Compliance Act (TSCA) Waste }\end{array}$ & $\$ 15,857$ \\
\hline Recycling of Lead X-Ray Sheets & HW & $\$ 2,305$ \\
\hline H-12 Outfall Experimental Peat Bed D\&R & LLW & $\$ 26,211$ \\
\hline $\begin{array}{l}\text { Reuse of Concrete Culverts Avoids Use of } 24 \text { New B-25 } \\
\text { (Storage and Transport) Containers per Year }\end{array}$ & Sanitary & $\$ 161,400$ \\
\hline $\begin{array}{l}\text { Polychlorinated Biphenyls (PCB) Tool Decontamination } \\
\text { and Reuse }\end{array}$ & Mixed TSCA & $\$ 112,030$ \\
\hline Radioactive Liquids Managed as Scavenger Wastewater & LLW & $\$ 8,336$ \\
\hline Bagging Process Water Deionizers @ K Area & LLW & $\$ 63,900$ \\
\hline Recycle DOE-Suspension Nonradioactive Lead & HW & $\$ 53,810$ \\
\hline $\begin{array}{l}\text { Recycle DOE-Suspension Radioactive Contaminated } \\
\text { Lead }\end{array}$ & Mixed LLW & $\$ 236,318$ \\
\hline Large Steel Box (LSB) Dewatering Savings & Mixed LLW & $\$ 83,252$ \\
\hline Liquid Waste Tank Farm Debris to Seven Springs Landfill & LLW & $\$ 82,950$ \\
\hline $\begin{array}{l}\text { 776-A Area Rollbacks from Contaminated Areas (CA) to } \\
\text { Radiological Buffer Areas (RBA) }\end{array}$ & LLW & $\$ 124,830$ \\
\hline Admin Controls Improve LLW Segregation & LLW & $\$ 14,490$ \\
\hline Legacy TRU Waste Segregation to LLW & TRU & $\$ 701,380$ \\
\hline $\begin{array}{l}\text { Bagging Reactor Process Water Deionizers for ILV } \\
\text { Waste Disposal }\end{array}$ & LLW & $\$ 95,850$ \\
\hline $\begin{array}{l}\text { RCRA Satellite Accumulation Area (SAA) Reduction at } \\
\text { Tritium Operations }\end{array}$ & LLW & $\$ 78,966$ \\
\hline Radioactive Lead Recycled by LWO & Mixed LLW & $\$ 271,240$ \\
\hline Tritiated Soil and Debris Remediation & LLW & $\$ 610,500$ \\
\hline
\end{tabular}

goal will be challenged. Figure 2-2 illustrates this comparison against the current baseline.

\section{Renewable Energy}

SRS has one biomass steam plant in permanent operation to service A Area and the Savannah River National Laboratory (SRNL). The site completed construction and startup of two additional biomass boilers in K Area and L Area in FY10. Construction on a new Biomass Cogeneration Facility near F Area continued, with startup expected in FY12. With respect to renewable energy certificates, SRS consumed more than 313,000 megawatt-hours of electricity in FY07. The new Biomass Cogeneration Facility will generate an estimated 77,500 megawatt-hours of electricity in its first year of operation. This production rate will be well above the 7.5-percent statutory goal for energy consumption that must come from renewable energy sources for FY13 and thereafter. 


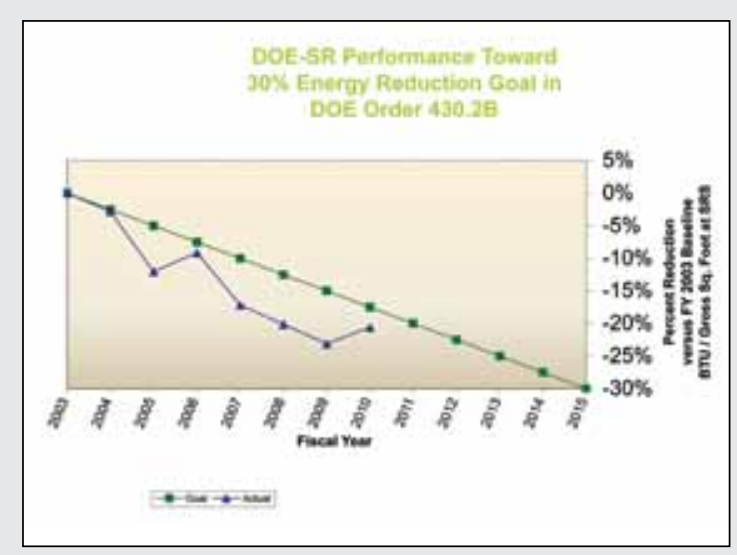

Figure 2-2 DOE-SR Energy Reduction Performance

The four SRS biomass plants were funded using energy savings performance contracts. The operational A Area plant's total project cost was $\$ 13.8$ million, with an annual savings average of more than $\$ 1.5$ million. The facility return-on-investment period (term of the contract) is 9 years.

The positive renewable and environmental impacts of the A Area/SRNL project during 2010 were as follows:

- Coal utilization reduced by more than 12,000 tons

- Biomass utilization increased by nearly 27,000 tons

- Particulate matter (PM) emissions reduced (PM from 411 tons/year to 7.36 tons/year, and PM (10 microns) from 300 tons/year to 4.38 tons/year)

- Sulfur dioxide emissions reduced from 1,836 tons/ year to 4.38 tons/year

- Nitrous oxide emissions reduced from 256.7 tons/ year to 35 tons/year

- Carbon monoxide emissions reduced from 120.8 tons/year to 105.1 tons/year

- Ash generation and disposal reduced from 2,260 tons/year to 300-600 tons/year

- Compliance with Clean Air and Water Act standards facilitated

\section{Water Management}

Potable water consumption was reduced by 27 percent in FY10 compared with the baseline year of FY00, and by nearly 2 percent between FY09 and FY10. When combining total potable and process water use, SRS realized a consumption decrease of approximately 12.3 percent from FY09 to FY10, despite increases in ARRA staffing and projects (see figure 2-3).

\section{Alternative Fuel}

E85 (85\% ethanol) fuel accounted for 54.5 percent of SRS's E85 and gasoline usage in FY10. About 81 percent of the site's light-duty fleet consists of E85 vehicles or hybrids. In the initial year of alternative fuel use (FY00), SRS consumed about 80,000 gallons of E85. By the end of FY10, this consumption total had risen to more than 368,000 gallons. The result is an increase of 350 percent since initiation of this fuel choice, which far exceeds the end-state goal of a 10-percent annual increase. Figure 2-4 visualizes the increased use of alternative fuel use since FY01.

\section{Transportation/Fleet Management}

Since FY99, SRS has reduced fleet petroleum use by 46 percent (Note: FY10 fuel data was determined using pre-Federal Automotive Statistical Tool inputs). Since the new base year for reporting (FY05), SRS has reduced fleet petroleum use by 9.76 percent - a decrease of about 1.5 percent through FY09. SRS petroleum consumption (combined gasoline and diesel) increased

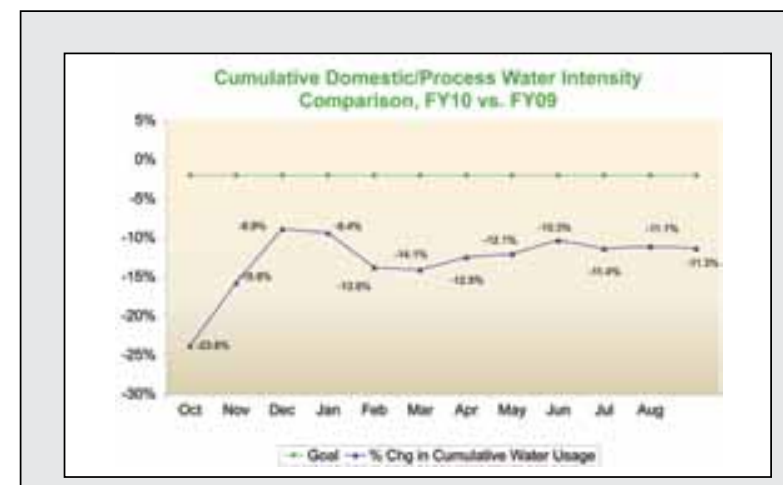

Figure 2-3 Domestic/Process Water Reduction Performance

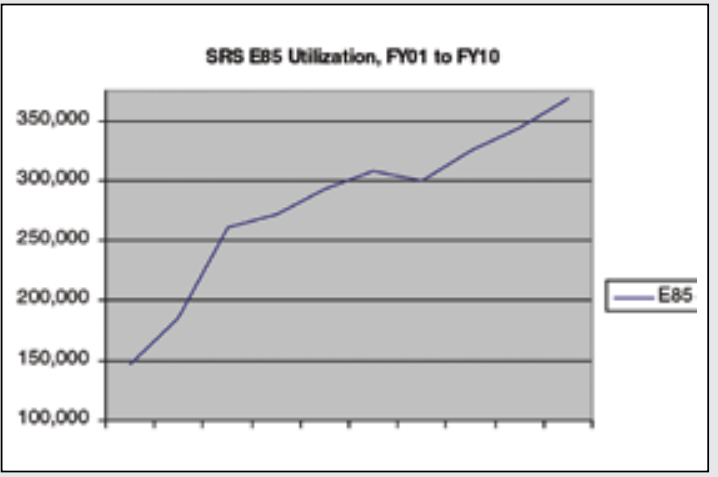

Figure 2-4 Increased E85 Usage at SRS 


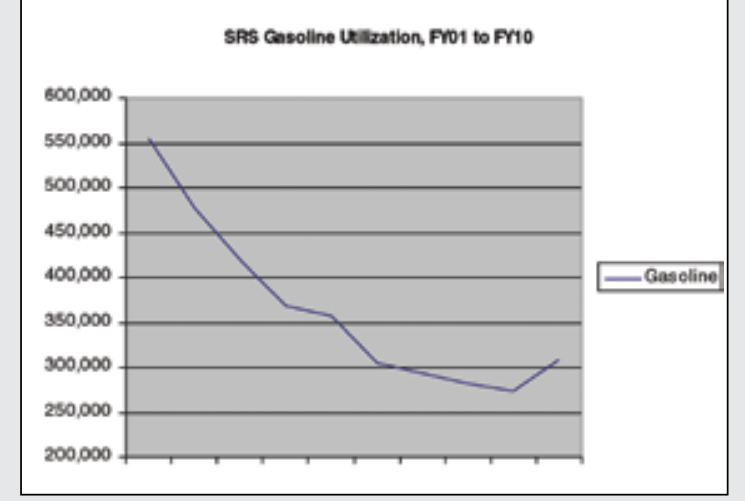

Figure 2-5 SRS Gasoline Reduction Performance

by nearly 21 percent from FY09 to FY10, primarily due to an increase in ARRA/stimulus staffing and scope. An additional contributor to the increase was a DOEHQ mandate to use approximately 60 hybrid gasoline vehicles at SRS. Because the hybrid vehicles cannot use blended E85 fuel, this mandate increased the site's use of unblended gasoline. However, the site is on track to meet the overall DOE reduction goal of 2 percent annually through FY15, having realized a 10-percent petroleum reduction through FY10, compared to the FY05 baseline year. Figure 2-5 demonstrates the reduction in SRS gasoline use since FY01. (NOTE: The FY10 increase is attributable to an increase in fleet size and use associated with ARRA/stimulus activities.)

\section{Contracts \& Concession Agreements}

The SRNS Procurement Department has implemented procedures to encourage acquisitions that comply with environmental requirements as evidenced through various contract-related documents, including (but not limited to) "Terms and Conditions" document (the paragraph entitled "Environmental Compliance") and "Request for Proposal" document (the paragraph entitled, "Environmentally Preferred Products"). Additionally, internally published procedures are documented in the site's Procurement Specifications Manual and Chemical Management Manual, and a number of procurement requirement documents are available on the SRS external website to facilitate understanding of SRS environmentally friendly requirements by current and/or potential vendors and subcontractors. As of the end of 2010, most Environmentally Preferred Product procurement initiatives have yielded success - primarily in the acquisition of janitorial support and safety functions.

The Procurement Department has not implemented a dedicated campaign to complete a comprehensive evaluation of existing contracts. Rather, its timeline regarding modification(s) to "appropriate contracts" is to address emergent environmental requirements as the contract(s) come up for renewal or rebid while reviews of defined roles and responsibilities are routinely conducted during the course of services delivery.

Either improvements to, or replacement of, existing Procurement databases must be completed to capture data detail that supports tracking/trending and process improvement initiatives. A campaign is under way to upgrade all automated business systems and among those are the Procurement applications, which are scheduled for implementation in October 2011.

\section{High-Performance Sustainable Buildings - New Construction}

DOE Order 430.2B ("Departmental Energy, Renewable Energy, and Transportation Management") stipulates that all new buildings and major renovations in the stages of preproject planning (approval of mission need) through conceptual design (approval of preliminary baseline range) that have not obtained preliminary design approval — and that have a value exceeding $\$ 5$ million-must achieve the U.S. Green Building Council's Leadership in Energy and Environmental Design (LEED $\Re$ ) Gold certification. Also, to the extent possible, and in consideration of life-cycle cost factors, such buildings must meet the Guiding Principles for Federal Leadership in High-Performance and Sustainable Buildings ("HPSBs"). Any buildings below or equal to the $\$ 5$-million threshold also must meet the Guiding Principles.

Support for these objectives is evident in the MOX Fuel Fabrication Facility administration building, which received LEED ${ }^{\circledR}$ Gold certification in FY10. This marks a major milestone, and the facility is the first at SRS to achieve this certification status. Additionally, the MOX-associated technical support building, which will be used for entry control/security and administration associated with the primary process building, is in the design stage and is incorporating LEED ${ }^{\circledR}$-Gold certification requirements as part of its design.

SRS developed and submitted three Critical Decision Packages for DOE-HQ approval during FY10, as follows:

- Approve Alternative Selection - Pit Disassembly and Conversion Project - proposes alternatives for constructing the Pit Disassembly and Conversion Project within existing facilities at SRS, primarily in the K-Area Complex. 
- Mission Need Package - Vacate Building 703-A Project (Savannah River Site Operations Center/ Emergency Operations Center; SRSOC/EOC) proposes to construct a new SRSOC/EOC in a modern structure of approximately 20,000 square feet, housing and consolidating the SRS emergency response organization and the SRS 24/7 Fire, Medical, and Law Enforcement emergency response activities in one location.

- Mission Need Package - Modernization of Mission Critical Infrastructure (MMCI) for Savannah River National Laboratory - proposes to construct the new Multiuse Technology Deployment Center to focus on reducing DOE-EM's highest risk and life-cycle cost projects while incorporating a design that (a) provides the flexibility to serve emerging non-DOE-EM missions and (b) facilitates sharing common infrastructure and critical skills.

\section{EMS Best Practices / Lessons Learned Savannah River Site Alternative Energy Research Initiatives}

Draft Legislation - House Resolution 5136 would authorize the Secretary of Energy to "Facilitate development of energy parks on defense nuclear facility reuse property through the use of collaborative partnerships with state and local governments, the private sector, and community reuse organizations." SRNL is actively assisting DOE-EM in the energy park concept. Energy park concepts are becoming a key focus area to respond to the nation's energy needs; SRS and SRNL are working closely with the Savannah River Community Reuse Organization and local economic development boards to move forward on an energy park. Energy parks can be characterized as a facility or group of facilities developed to promote energy security, environmental sustainability, economic competitiveness, and energy sector jobs. The concept works to redeploy under-utilized DOE assets to produce diverse, green, domestic energy sources such as solar, wind, biomass, geothermal, nuclear, clean coal, hydrogen, smart grid, storage, and efficient manufacturing. The energy park concept also encourages pilot programs, demonstration projects, or commercial projects with respect to energy generation, energy efficiency, and manufacturing technologies that will contribute to the stabilization of atmospheric greenhouse gas concentrations through the reduction, avoidance, or sequestration of energy-related emissions.

\section{Geothermal Performance-Optimized Datacenter}

In 2010, SRNL acquired a Performance-Optimized
Datacenter (POD) (to house high-performance scientific computing equipment) that will utilize groundwater cooling resources at SRS.

The POD, the size of a standard 40-foot shipping container, will provide the equivalent of 4,000 square feet of traditional data center space and will be used to demonstrate cost-savings and energy-efficient technologies supporting DOE goals. More specifically, it will use a geocooling technique that eliminates the need for chilled water normally used in the traditional data center. The POD will be populated with next-generation cloud and graphical processing unit computing hardware that allows thousands of new processors to be incorporated into the same space as hundreds of previous traditional CPU processors. This technology is essential to meeting future SRNL simulation and visualization demands. The containerized computing environment, combined with the latest computing technologies, places SRNL in a strategic position to study and evaluate new power and cooling technologies for datacenter environments, as well as for many other applications. It is anticipated that this technology could lead to new opportunities for collaboration with other national laboratories, research institutions and universities, and industries.

\section{Chemical Management Center}

The CMC provides centralized control of chemical materials procurement and of excess chemical materials management with goals to reduce the volume and toxicity of chemical procurements, reduce chemical inventories and waste, and improve tracking and communication of chemicals currently in onsite inventory. Hazardous and nonhazardous chemicals are reutilized on site, returned to vendors when possible, sold through sealed bid sales to approved vendors, and donated to local-area government institutions to promote good community service in order to reduce waste generation. As previously noted, the CMC distributed for reuse more than 84,773 pounds of chemicals in FY10, avoiding more than $\$ 1.2$ million in chemical acquisition and waste management costs.

\section{Awards and Recognitions}

SRS believes that significant contributions to site missions that positively impact the local and surrounding environment should be recognized. As such, site activities and projects across the site are evaluated for noteworthy practices, implementation of new and emerging technologies, and insightful approaches to resolving environmental stewardship issues. To that end, SRS received two DOE National Pollution Prevention 
Awards in 2010: one in the category of Waste/Pollution Prevention and the other in the category of Sustainable Design/Green Buildings.

\section{Detoxification of Outfall Water Using Natural Organic Matter}

The first award was presented for development of a technology that protects streams and rivers from the toxic effects of outfall discharges - a significant national priority. Traditional treatment systems are based on standard water treatment techniques to remove the toxic contaminant(s). An SRS project team developed and applied for a patent in January 2009 for an entirely new "detoxification" approach to address contaminants such as copper and implemented the new technology in June 2009. This system amends outfall water with natural organic matter to bind copper and mitigate toxicity, protecting the sensitive species in the ecosystem. The system does not generate any waste requiring removal, treatment, and/or disposal. The amendments are commercial products that are naturally rich in humic acids and are commonly used in organic agriculture. For the SRS H-12 outfall and similar facilities where this innovative "green" technology will be viable, the detoxification system protects the environment while reducing energy use, land disturbance, and costs. Cost avoidance is estimated at more than $\$ 10$ million for the life of the project. The construction permit for the system was approved by state regulators in September 2008, and the new technology is believed to offer significant benefits over traditional treatment systems.

\section{SRS Constructed Wetlands Reduce Environmental Impacts}

The second award was presented for use of constructed wetland treatment systems to reduce pollution discharges to streams from two operational facilities in A Area and $\mathrm{H}$ Area. These systems eliminate the need for both power and chemicals normally associated with wastewater purification. Two self-sustaining wetland treatment systems were placed into operation in September 2000 (A Area) and January 2008 (H Area) to eliminate toxicity and reduce the discharge of heavy metals into onsite streams. The gravity flow design of these treatment systems eliminates the need for powerconsuming pumps for moving wastewater through the systems. The scientific selection of plant species for colonization eliminates the need for harvesting, while annual dieback of plant shoots renews the metal binding surfaces in each wetland system and develops a peat bed over time. Thus, no chemicals are needed for chemical precipitation, and no sludge is generated that requires disposal. Energy to operate the systems is provided by the sun to grow the plants, which cycle back into the systems as beneficial organic detritus. In 2010, the wetland systems greatly reduced the construction, operating, and maintenance expenses associated with water treatment, and did not produce secondary waste that would require further treatment or disposal. Savings of more than $\$ 570,000$ were realized in 2010 due to selection of the wetland systems over conventional water treatment facilities. The use of wetlands for water treatment represents the essence of sustainable design principles requiring minimal maintenance and minimizing energy usage and pollutant discharges.

\section{Ongoing Environmental Enhancement Projects}

The environmental projects and accomplishments identified below are additional examples of the scale and scope of improvement opportunities being implemented at SRS - and were submitted for national award consideration in 2010.

\section{Tritiated Debris Remediation Project}

SRS successfully piloted, received regulatory approval and continued expanding implementation of a thermal treatment process in 2010 to remediate tritium contaminated debris to allow return of the debris for placement back in the remediation site, while meeting regulatory limits. SRS demonstrated that functional, reusable treatment cells can be readily fabricated using common, inexpensive construction materials and commercially available process control and heating equipment. A pilot cell and three new cells will be used to treat 3,500 cubic yards (equivalent to 200 trailer-truck loads) of contaminated concrete and soils that would have required packaging and shipment to offsite disposal. This is expected to avoid more than $\$ 1.6$ million in transportation costs (exclusive of any additional packaging and handling requirements), including more than 400,000 truck miles. The remediation site has become a living laboratory, allowing development, proof-of-principle, and implementation of a cost-effective technology now available for use at other SRS and DOE remediation sites.

\section{SRS Vehicle Energy and Emissions Reduction}

SRS has been successfully implementing multiple fleet management fuel reduction and inventory strategies since the mid-1990s, and has surpassed reduction goals from previous baselines. Various approaches have been undertaken, and will continue in FY11, to reduce petroleum consumption, increase alternative 
fuel use, and increase the number of alternative fuel vehicles. In FY10, SRS also accepted the challenge to reduce health risks associated with vehicular exhaust emissions at the site and in the surrounding three counties. With the 3,000 jobs created through the ARRA, SRS has experienced an increase in both commercial and personal site-associated travel, which in turn has increased traffic and vehicular air pollution during peak ozone periods. In an effort to maintain and even reduce harmful vehicular air emissions, SRS retrofitted older site vehicles with emission control technologies, implemented a policy restricting the idling of commercial vehicles, and reduced personal vehicle miles traveled by encouraging carpooling. These efforts are summarized below.

- Fleet Acquisition Petroleum Reduction - Although the SRS fleet size rose slightly in FY10 due to increased vehicle demand resulting from the 3,000 jobs created by ARRA/stimulus efforts, the Site is still on track to meet the overall goal requirement of 2-percent annual petroleum use reduction through FY15. The SRS fleet is provided by the General Services Administration (GSA). In FY10, 81 percent of the existing light duty fleet at SRS consisted of alternative fuel vehicles (AFVs) or hybrid vehicles, including 514 E85 AFVs and 82 hybrids in the light duty fleet. The site expects to receive an additional 14 replacement hybrid vehicles in FY11. A full 100 percent of the heavy-duty fleet operates on diesel fuel versus gasoline. Since FY99, SRS has reduced fleet petroleum use by 46 percent. Since the new base year for reporting (FY05), SRS has reduced fleet petroleum use by 9.76 percent despite a slight increase in FY10 usage due to ARRA work scope. The site continues on track to meet the overall goal requirement of 2-percent annual petroleum use reduction through FY15. In FY10, E85 consumption rose to more than 368,000 gallons - an increase of 350 percent since initiation of this fuel choice in FY00. E85 fuel made up about 54 percent of the fuel consumed in gasoline/E85 vehicles. SRS has established a fuel card system whereby E85/flex-fuel vehicles cannot utilize gasoline pumps. Consequently, nearly 100 percent of all AFVs operate on E85.

- DERA Grant - In September 2009, SRS was awarded a State of South Carolina Diesel Emission Reduction Act (DERA) Grant that enabled the site to install emission reduction equipment on nine of the 13 emergency vehicles owned and operated by the SRS Fire Department. The nine diesel vehicles were manufactured between 1979 and 1995, and had traveled an average of 3,500 miles per year. All nine were retrofitted with EPA-verified control equip- ment in FY10. The retrofitted vehicles reduce carbon monoxide emissions by 30 percent, volatile organic compounds by 50 percent, and PM emissions by 20 percent.

- Site "No Idling" Policy - SRS has voluntarily implemented practices to comply with South Carolina's "Idling Restrictions for Commercial Diesel Vehicles" law. The "No Idling" language was included in the General Provisions section of all outgoing contracts for work beginning in August 2009. In FY10, SRS adopted the statue as a sitewide policy to encourage all vendors entering SRS for business to reduce the amount of time they idle while waiting to be loaded and unloaded. This effort reduces ozone precursor emissions from diesel exhaust. "No Idling Zone" signs were posted in various onsite loading and unloading areas, which serve approximately 40 to 45 commercial vehicles a week.

- SRS Car Pool Web Page - SRS unveiled its own carpool webpage in FY10 for all site personnel interested in carpooling. Information from both Georgia's Clean Air Campaign and South Carolina's Take A Break From The Exhaust program are accessible from the webpage. Other notable information regarding proposed local "Park and Ride" facilities and vanpooling opportunities also are available as links. The webpage continues to facilitate ridesharing between co-workers interested in reducing their vehicle miles traveled by carpooling and/or vanpooling. Since conception, the tracked South Carolina residents' ridesharing participation has increased by 196 participants, while Georgia residents' participation has increased by 309 participants.

\section{Recycling Wastewater Benefits SRS Waste Tank Closure Process}

LWO personnel continue to deploy new technologies and approaches to traditional operational practices for radioactive liquid waste processing for savings in both waste volume and life cycle cost avoidance. While continuing to deploy robotics and remote operations for tank clean-up, LWO is accelerating implementation of a unique wastewater recycling program at SRS.

By recycling wastewater and chemicals used in cleaning radioactive high-level waste tanks, LWO is moving away from adding new water and chemicals into the system. In 2010, after just over a year of operations using these new process improvements, more than 2.8 million gallons of wastewater and 100,000 gallons of 50 -percent sodium hydroxide solution had been reused in tank cleaning and waste removal processes. The site's objective is to clean out 22 old-style liquid waste tanks 
in eight years. Dissolving the salt waste and mobilizing the sludge waste to transfer them to pretreatment and treatment facilities is expected to require millions of gallons of inhibited process water and to consume more than the currently available tank space in both the $\mathrm{F}$ Area and H Area tank farms. Efforts continued in 2010 to allow for tank cleaning while maintaining tank space for operational flexibility.

Lessons learned from these process improvements have the potential for similar savings at DOE's Hanford Site in Richland, Washington, during that facility's tank closure operations.

\section{SRS Electronic and Data Center Optimization}

SRS continued its work during 2010 to optimize energy management associated with data centers and electronic computing equipment. In FY10, SRNS Information Technology (IT) and DOE-SR personnel worked with a DOE-EM team, led by Lawrence Berkeley (California) National Laboratory, to measure, monitor, and improve data center energy efficiency. Based on the identified and implemented improvements, the data center achieved an average net savings of 166.3 kilowatts, equating to a reduction of 30.7 percent in energy use. The "Power Usage Effectiveness," a metric that depicts the ratio of a facility's total power consumption divided by the power going to IT equipment, showed a substantial improvement-from 3.75 to 2.60. Moreover, these changes were essentially "free." In addition to the data center efforts, computer leases for the site continued to meet Energy Star, Electronic Procurement Environmental Assessment Tool (EPEAT), and lowstandby power requirements.

Other data center/electronic computing equipment best practices include

- continuation of server virtualization (currently at 30 percent)

- implementation of thin client technologies for offsite access from employee-owned personal computers instead of DOE-owned laptops

- $\quad$ replacement of obsolete chiller units

Computer Acquisition Energy efficient computer products continued to be purchased at SRS in 2010. Most site computers are provided to employees via lease agreements, which are leveraged for the needs of multiple site companies and specifically state that all computers must be Energy Star compliant and must meet low standby power requirements. While most models being leased have been EPEAT compliant since
FY07, the final model became compliant in FY09. The pre-EPEAT models have continued to be replaced with EPEAT-compliant models as their 36-month leasing cycles expired. The 2 percent remaining are scheduled to be replaced through early CY11. The power reduction features of the personal computers and monitors are set to efficient levels upon receipt of the equipment.

\section{Renewable Energy Technology Development, Deployment and Education in South Carolina}

SRNL and the Economic Development Partnership of South Carolina (EDPSC) have collaborated to develop and deploy renewable energy technologies within the local community and the state of South Carolina. Through this collaboration, SRNL has shared its expertise and knowledge of renewable energy technologies with EDPSC, which in turn has leveraged existing relationships with industry to identify and evaluate specific opportunities. The collaboration has assisted local industry in lowering harmful emissions through deployment of these technologies, and has led to the establishment of public education and outreach to the community on the topic of renewable energy technologies. The collaboration was conceived by SRNL researchers working to deploy dual-use hydrogen technology developed during the Cold War. The EDPSC recognized the economic potential of the SRNL technology and convinced a local government (Aiken County) to fund a public/private research and development laboratory focused on deploying renewable energy technologies with South Carolina. This collaboration has led to a number of successful projects and has established South Carolina as a leader in hydrogen technology development and deployment. It also initiated the characterization and development of South Carolina offshore wind resources, which has led to the creation of a statewide wind energy team. The SRNL-EDPSC collaboration also has deployed fully integrated wind, solar, hydrogen, and smart grid educational platforms designed to educate $\mathrm{K}-12$ students and to train future South Carolina installers of renewable energy technology. More than \$15 million in private and/or local government funding has been invested or leveraged by this collaboration to further the deployment of renewable energy technologies, including the installation of new wind turbines in 2010.

\footnotetext{
Project Results to Date: Renewable Energy Projects in South Carolina The cornerstone of the SRNLEDPSC collaboration has been the 2006 opening of the Center for Hydrogen Research (CHR), a 60,000-squarefoot facility that provides research and development space for more than 80 engineers and scientists from
} 
SRNL, commercial companies (e.g., Toyota) and universities (e.g., University of South Carolina-Aiken). Funded by Aiken County through private investment, the CHR mission is to develop and deploy hydrogen and renewable energy technologies for local, state, and national missions. Since the opening of the CHR, SRNL and the EDPSC have successfully completed the following list of projects, which primarily leverage private, local, and state funding sources:

- In 2009, a 1,500-square-foot public Educational, Training \& Development Center with a fully integrated solar, wind, hydrogen, and smart grid training platform was opened to develop and demonstrate clean regenerative power systems. The training venue, supported by private funding, has educated more than 60 students from local K-12 schools and technical colleges on renewable energy technologies. The system includes a 15-kilowatt solar panel system, an electrolyzer, a 2-kilogram solid state hydrogen storage fuel cell, and smart grid electronics to allow load balancing and power source switching.

- Through industrial funding sources, 68 hydrogenfuel-cell-powered fork lift trucks were deployed at two local manufacturing facilities (BridgestoneFirestone in 2009-2010 and Genco Distribution Center in 2010).

- One hydrogen-powered Chevrolet Silverado truck and two hydrogen powered Ford 15-passenger vans were deployed in 2010 to service the local community within 150 miles of SRS.

- An automotive/industrial hydrogen refueling station was installed near I-20 in Aiken County to allow refueling of vehicles up to $350 \mathrm{bar}$ (a standard of measure for quantifying atmospheric pressure).

- The nation's first multiuse industrial park fueling station to supply hydrogen for industrial, commercial, and government use was developed/deployed near Aiken in 2010. The park includes hydrogen storage, pipelines, and metering systems, which supply local manufacturing facilities.

- Work on the Regenerative Fuel Cell Project was begun at Fort Sumter National Park to provide backup power to the park.

- Through a grant from the EDPSC, SRNL has deployed advanced offshore wind characterization technology on the South Carolina coast and in nearby coastal waters. With a $\$ 500,000$ grant from the State of South Carolina and its partners, the deployment of "Sodar" technology in the state's coastal waters is expected to lead to offshore wind development along the Southeastern coast. SRNLEDPSC also has initiated a small wind characterization project within South Carolina that will characterize and test turbines specifically designed for low-velocity winds. This effort led in 2008 to the formation of a statewide wind energy development team, which in 2009 won a $\$ 98$ million grant $(\$ 48$ million from DOE and $\$ 50$ million from the State of South Carolina and partners) to build a wind turbine drive train test facility in North Charleston, South Carolina.

Offshore wind energy developments have led South Carolina to becoming an east coast leader in such energy. The early success of activities in this collaboration led to the formation of a statewide team that won a $\$ 500,000$ grant from DOE to create a policy framework and regulatory environment to enable gigawatt-scale clean-energy capacity. Based on this team's efforts, the South Carolina legislature passed Act 318 of 2008 (an amendment to S.C. Title 48, "Environmental Protection and Conservation"), which created a committee to review, study, and make recommendations regarding the feasibility of wind turbine farms in the state.

Research conducted by SRNL and partially supported by EDPSC has led to a national DOE hydrogen program award and an International Energy Agency award.

\section{EMS Benefits to Agency Mission}

Although methods of execution vary from site to site and contractor to contractor, implementation of an EMS provides an understood and recognized structure to standardize the evaluation of, preparation for, and execution of activities and projects having environmental implications within distinct and separate organizations that are engaging in activities and projects with overlapping interests. More specific instances in which an EMS can benefit DOE's mission are provided below.

- Policy development and program planning facilitates to enhance integration of environmental compliance programs

- Promotion of environmental stewardship throughout the project planning cycle (cradle to grave)

- Solid waste offsite contract evaluation to ensure that best management practices and appropriate stewardship protocols are built into contracts

- Enabling a clear/consistent flowdown of expectations and compliance framework in contracting documents 
- Clear articulation of DOE complexwide EMS requirements to promote consistency in contract specifications and environmental management expectations
For Further Information Should additional information be required relative to this chapter, contact Michael Roper at michael.roper@srs.gov. 


\title{
Compliance Summary
}

\author{
Jana Ackerman \\ Regulatory Integration and Environmental Services \\ Michele Wilson \\ Regulatory Integration and Environmental Services
}

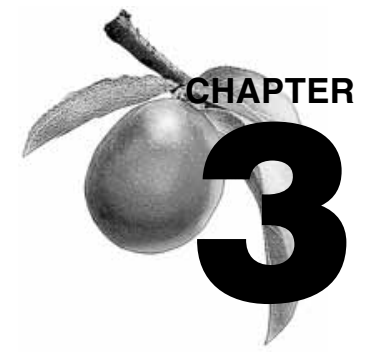

\footnotetext{
$t$ is the policy of the U.S. Department of Energy (DOE) that all activities at the Savannah River Site (SRS) will

fully comply with applicable federal, state, and local environmental laws and regulations, and with DOE orders, notices, directives, policies, and guidance. Compliance with environmental regulations and with DOE orders related to environmental protection is a critical part of safe operations at SRS.
}

The purpose of this chapter is to report the status of SRS compliance with applicable statutes and programmatic documents. Some key regulations with which SRS must comply are listed in table $3-1$.

The chapter is divided into five separate sections: Compliance Status, Other Environmental Issues/Actions, Continuous Release Reporting, Unplanned Releases, and Permits.

The Compliance Status section identifies the various environmental laws, regulations, and DOE orders with which SRS must comply, and the status of the site's compliance programs.

The Other Environmental Issues/Actions section provides information on any Notices of Violation (NOVs) or Notices of Alleged Violation (NOAVs) issued to SRS in 2010 by the U.S. Environmental Protection Agency (EPA) or the South Carolina Department of Health and Environmental Control (SCDHEC). NOVs/NOAVs are the formal regulatory notices that allege violations of an organization's permits, or of environmental laws or regulations. SRS received one NOV and one NOAV in 2010.

No releases required reporting to local emergency planning committees, as noted in the Continuous Release Reporting and Unplanned Releases sections. A list of environmental permits held by SRS appears in data table 3-1 on the CD housed inside the back cover of this report.

\section{Compliance Status}

This section includes discussions of compliance with applicable environmental laws and regulations, DOE orders, and agreements with regulators. It addresses environmental remediation, waste management, radiation protection, air and water quality and protection, and other environmental statutes and DOE orders.

\section{Environmental Restoration and Waste Management Remediation/Cleanup}

SRS was placed on the National Priority List (NPL) in December 1989, under the legislative authority of the Comprehensive Environmental Response, Compensation, and Liability Act (CERCLA), as amended by the Superfund Amendments and Reauthorization Act of 1986 (SARA). The site was added to the NPL because there have been releases or threatened releases of hazardous substances, pollutants, or contaminants, which EPA evaluated through a hazard ranking system on the likelihood that a release occurred, on the characteristics of the waste, and on the environment affected by the releases. Placement on the NPL indicated SRS warranted further investigation to assess the nature and extent of the public health and environmental risks associated with the releases, and to determine the appropriate remedial action(s), if any. DOE, EPA Region 4, and SCDHEC - in accordance with Section 120 of CERCLA - entered into the Federal Facility Agreement (FFA), which became effective August 16, 1993, and which directs the comprehensive environmental remediation of the site. The FFA, which integrates CERCLA and RCRA requirements to achieve a comprehensive remediation of SRS, governs the corrective/remedial action process, sets annual work priorities, and establishes milestones for activities. The agreement also coordinates administrative and public participation requirements. 
Table 3-1 Laws/Regulations Applicable to SRS

Legislation What It Requires

\section{RCRA}

Resource Conservation and

Recovery Act (1976)

\section{FFCAct}

Federal Facility Compliance Act (1992)

\section{CERCLA; SARA}

Comprehensive Environmental

Response, Compensation, and Liability

Act (1980); Superfund Amendments

and Reauthorization

Act (1986)

\section{EPCRA}

Emergency Planning and Community Right-to-Know Act (1986)

\section{NEPA}

National Environmental Policy Act (1969)

\section{SDWA}

Safe Drinking Water Act (1974)

\section{CWA}

Clean Water Act (1977)

\section{RHA}

Rivers and Harbors Act of 1899 ,

Section 10

\section{FIFRA}

Federal Insecticide, Fungicide, and

Rodenticide Act (1947)

\section{CAA (NESHAP)}

Clean Air Act (1970), (National

Emission Standards for Hazardous Air Pollutants)

\section{CAAA}

Clean Air Act Amendments of 1990

\section{TSCA}

Toxic Substances Control Act (1976)

\section{ESA}

Endangered Species Act (1973)

\section{NHPA}

National Historic Preservation Act (1966)
The management of hazardous and nonhazardous solid wastes and of underground storage tanks containing hazardous materials and wastes

The subjection of federal agencies to all substantive and procedural requirements of federal, state, and local solid/hazardous waste lawsin the same manner as any private party

The establishment of liability, compensation, cleanup, and emergency response for hazardous substances released to the environment. The Federal Facility Agreement (FFA) (WSRC-OS-94-42) between EPA, DOE, and SCDHEC integrates CERCLA and RCRA requirements to achieve a comprehensive remediation of SRS. The FFA governs the corrective/remedial action process, sets annual work priorities, and establishes milestones for activities. The agreement also coordinates administrative and public participation requirements.

The reporting of SRS hazardous substances (and their releases) to EPA, state emergency commissions, and local planning units

The evaluation of the potential environmental impacts of proposed federal activities and alternatives

The protection of public drinking water resources

The regulation of liquid discharges at outfalls (e.g., drains or pipes) that carry effluents to streams (NPDES, Section 402); regulation of dredge and fill of U.S. waters (Section 404) and associated water quality for those activities (WQC, Section 401)

The regulation of construction over and obstruction of navigable waters of the U.S.

The regulation of restricted-use pesticides through a state-administered certification program

The establishment of air quality standards for criteria pollutants, such as sulfur dioxide and particulate matter, and of hazardous air emissions, such as radionuclides and benzene

The establishment of a national permit program, and of provisions for addressing acid rain, ozone depletion, and toxic air pollution

The regulation of $\mathrm{PCBs}$, radon, asbestos, and lead, as well as evaluation and notification to EPA of new chemicals and significant new uses of existing chemicals

The protection of critically imperiled species from extinction

The preservation of historical and archaeological sites 
SRS has 515 waste units in the Area Completion Projects program, including RCRA/CERCLA units, Site Evaluation Areas, and facilities covered under the SRS RCRA permit. At the beginning of FY10, surface and groundwater cleanup of 374 of these units were complete or in the remediation phase ( 368 complete and six in the remediation phase). At the end of FY10, 386 units were complete or in the remediation phase (373 complete and 13 in remediation). A summary of the FY10 FFA milestones follows.

RCRA Facility Investigation/Remedial Investigation (RFI/RI) field starts were initiated for the following units:

- B Area Operable Unit

- Lower Three Runs Integrator Operable Unit (Third Phase II)

- Steel Creek Integrator Operable Unit (Including L Lake, no building number, and L-Area Reactor Discharge Canal) (Fourth Phase II)

Remedial Actions were initiated at the following units:

- E-Area Low Level Waste Facility, 643-26E (Slit Trench Disposal Units 1-5), Interim Action

- Early Construction and Operational Disposal Site (ECODS) L-1, N-2, P-2, and R-1A, $-1 \mathrm{~B},-1 \mathrm{C}$

- P Area Operable Unit Early Action

Remedial actions were completed and Post-Construction Reports (PCRs) or Post-Construction Reports/Corrective Measures Implementation Report/Remedial Action Completion Reports (PCR/CMIR/RACRs) were submitted to EPA and SCDHEC for the following unit:

- M Area Operable Unit

Records of Decision (RODs) were submitted to EPA and SCDHEC for the following units:

- D Area Operable Unit

- Gunsite 012 Rubble Pile, Rubble Pile Across from Gunsite 012, and ECODS G-3 Operable Unit

- Gunsite 218 Rubble Pile Operable Unit (631-23G)

- P Area Operable Unit

- R Area Operable Unit

RODs or Interim RODs were approved by EPA and SCDHEC for the following units:

- $\quad$ ECODS L-1, N-2, P-2, and R-1A, $-1 \mathrm{~B},-1 \mathrm{C}$

- Gunsite 218 Rubble Pile (631-23G)

- P Area Operable Unit

- E Area Low Level Waste Disposal Facility, 643-26E (Slit Trench Disposal Units 1 and 2)
RODs or Interim RODs were issued for the following units:

- P Area Operable Unit

- ECODS L-1, N-2, P-2, and R-1A, $-1 \mathrm{~B},-1 \mathrm{C}$

- E Area Low Level Waste Disposal Facility, 643-26E (Slit Trench Disposal Units 1 and 2)

An Explanation of Significant Difference (ESD) was submitted and approved by EPA and SCDHEC for the following unit:

- E-Area Low Level Waste Facility, 643-26E, Interim Action

ESDs were issued for the following units:

- P Area Operable Unit Early Action

- E Area Low Level Waste Facility, 643-26E (Slit Trench Disposal Units 1 and 2)

Section X ("Site Evaluations") of the FFA requires SRS to submit Removal Site Evaluation reports to EPA and SCDHEC for (1) those areas with potential or known releases of hazardous substances not identified before the effective date of the agreement, and (2) those areas listed in appendix G.1 of the agreement.

SRS submitted six Revision 0 Removal Site Evaluation reports, as follows:

- C Area Reactor Area Cask Car Railroad Tracks as Abandoned

- ECODS B-3 (East of B Area, South of Road C) and ECODS B-5

- In Situ Decommissioning of the 105-C Disassembly Basin

- P Area Ash Basin (Including Outfall P-007) (188-P) and the R Area Ash Basin (188-R)

- R Area Process Sewer Line Combined Subunit for the R Area Operable Unit

- Small Arms Training Area

The FFA requires, by January 1 of each year, submittal of an annual removal action report describing all removal actions performed during the previous fiscal year. SRS submitted the report December 21, 2010, to EPA and SCDHEC. The FY10 report described 18 active removal action areas and 34 maintenance activities.

A listing of all 515 waste units at SRS can be found in appendices C ("RCRA/CERCLA Units List") and G ("Site Evaluation List") of the FFA (http://www.srs.gov/ general/programs/soil/ffa/ffa.html). 


\section{Liquid Radioactive Waste Tank Closure}

The primary regulatory goal of the waste tank closure program at SRS's F Area and $\mathrm{H}$ Area liquid radioactive waste tank farms is to operationally close the tank systems under the FFA and SCDHEC regulations, which establish requirements for tank system(s) being removed from service. Under these requirements, Tanks $17 \mathrm{~F}$ and 20F in the F Area Tank Farm were closed in 1997.

During CY10, waste removal and tank closure activities continued in 15 of the 22 remaining old-style tanks. SCDHEC and EPA have preliminarily concurred that waste removal activities can cease regarding tanks $5 \mathrm{~F}$, $6 \mathrm{~F}, 18 \mathrm{~F}$, and $19 \mathrm{~F}$, allowing for sampling and analysis of residual waste in the tanks. Waste treatment technology development continued in 2010, with the program exploring deployment of small-column ion exchange, rotary microfilters and next-generation solvents for the treatment of salt waste. The Defense Waste Processing Facility accelerated vitrification of sludge waste, due in part to the installation of additional bubblers in the melter and enhanced off-gas capability. DOE Order 435.1 draft Tier 1 closure documentation for F Area Tank Farm was submitted to DOE-HQ for review December 10,2010 , and the comments were being incorporated into the document at the end of the year. A revised $\mathrm{F}$ Area Tank Farm General Closure Plan is expected to be approved by SCDHEC in early 2011 .

\section{Resource Conservation and Recovery Act}

Congress enacted the Resource Conservation and Recovery Act (RCRA) in 1976. RCRA established a system for managing hazardous and nonhazardous solid wastes in an environmentally sound manner. Specifically, it provides for the management of hazardous wastes from the point of origin to the point of final disposal ("cradle to grave"). RCRA also promotes resource recovery and waste minimization.

The Hazardous and Solid Waste Amendments (HSWA) of 1984 expanded the scope and increased the requirements of RCRA. HSWA addressed congressional concern about the adequacy of existing requirements to prevent uncontrolled releases of hazardous constituents or hazardous wastes from hazardous waste management units. Three of the HSWA initiatives were especially noteworthy in preventing or addressing hazardous waste/ constituent releases:

- Congress directed EPA to develop what is now known as the Land Disposal Restrictions (LDR) Program - under which the land disposal of untreated wastes is prohibited.

- Facilities are required to satisfy minimum technology requirements (i.e., liners and leachate collection systems) for surface impoundments, waste piles, land treatment units, and landfills to prevent hazardous wastes and/or constituents from migrating into the groundwater and to allow releases to be detected when they occur.

- When a facility seeks a RCRA permit, EPA is granted the authority to require corrective action for releases of hazardous waste and hazardous constituents from any solid waste management unit, regardless of when the waste was placed in the unit.

The 19 underground storage tanks at SRS that contain petroleum products, as defined by CERCLA, are regulated under Subtitle I of RCRA. These tanks require a compliance certificate annually from SCDHEC to continue operations. SCDHEC conducts an annual compliance inspection and records audit prior to issuing the compliance certificate. SCDHEC's 2010 inspection and audit found all 19 tanks to be in compliance, marking eight straight years without a violation.

The 1984 RCRA amendments established LDRs to minimize the threat of hazardous constituents migrating to groundwater sources. The same restrictions apply to mixed (hazardous and radioactive) waste.

\section{Mixed Waste Management}

The Federal Facility Compliance Act (FFCAct) was signed into law in October 1992 as an amendment to the Solid Waste Disposal Act to add provisions concerning the application of certain requirements and sanctions to federal facilities. A Site Treatment Plan (STP) (WSRCTR-94-0608) consent order (95-22-HW, as amended) was obtained and implemented in 1995, as required by the FFCAct. A Statement of Mutual Understanding for Cleanup Credits was executed by SCDHEC in October 2003, allowing SRS to earn credits for certain accelerated cleanup actions. Credits then can be applied to the STP commitment schedules. The 2009 annual update was approved by SCDHEC May 24, 2010. SRS submitted the 2010 annual update (SRNS-TR-200800101, Rev 2) of the approved STP to SCDHEC in November 2010. The update identifies changes in mixed waste treatment and inventory.

The STP 2010 update documents storage of 142,901.34 cubic meters of mixed waste as of July 31,2010 , versus 138,732.01 cubic meters in 2009 (table 11.1, volume II, chapter 11). Changes in this update also include consolidating transuranic (TRU) waste stream SRW026, CH Mixed TRU/Thirds, with SR-W027, CH Mixed TRU, and implementing enhanced inventory controls. 


\begin{tabular}{|c|c|}
\hline \multicolumn{2}{|c|}{$\begin{array}{l}\text { Table 3-2 Summary of SRS-Related } \\
\text { NEPA Reviews in } 2010\end{array}$} \\
\hline Type of NEPA Review & Number \\
\hline Categorical Exclusion Determinations & 203 \\
\hline "All No" EEC Determinations" & 158 \\
\hline $\begin{array}{l}\text { Actions Tiered to Previous NEPA } \\
\text { Reviews }\end{array}$ & 14 \\
\hline Environmental Impact Statements ${ }^{b}$ & 4 \\
\hline Supplement Analysis ${ }^{c}$ & 1 \\
\hline Interim Action & 0 \\
\hline Revised FONSI & 1 \\
\hline Environmental Assessments ${ }^{d}$ & 1 \\
\hline Total SRS-Related NEPA Reviews & 382 \\
\hline \multicolumn{2}{|c|}{ a Proposed actions that require no further NEPA review } \\
\hline \multicolumn{2}{|c|}{$\begin{array}{l}\text { b } \mathrm{DOE} / \mathrm{EIS}-0283-\mathrm{S} 2 \text { (in progress); DOE/EIS-0375 (in } \\
\text { progress); DOE/EIS-0423 (in progress); } \\
\text { DOE-EIS-0327 (schedule uncertain) }\end{array}$} \\
\hline \multicolumn{2}{|c|}{$\begin{array}{l}\text { " SA for SRS Spent Nuclear Fuel Management FEIS } \\
\text { DOE/EIS-0279 (in progress) }\end{array}$} \\
\hline d DOE/EA-1606 (in progress) & \\
\hline
\end{tabular}

Previously, volumes for waste stream SR-W009 (silvercoated packing material) were reported as volumes of the containment culvert rather than those of the primary waste container itself. A 2010 accounting practice refinement will result in reporting volumes of the primary waste containers. No SR-W009 waste was shipped in 2010.

SRS has successfully completed more than 80 STP mixed waste management commitments since its establishment.

\section{National Environmental Policy Act}

The National Environmental Policy Act (NEPA) is the federal government's basic charter for ensuring the protection and wise use of the "human environment." NEPA procedures require that federal agencies identify and consider the potential environmental consequences of their proposed actions early in the planning process so they can make informed, environmentally sound decisions regarding project design and implementation. The NEPA process at SRS is initiated by completing an Environmental Evaluation Checklist (EEC). The EEC is used to characterize the proposed action, identify any potential environmental concerns, and determine which level of NEPA review (if any) will be required [i.e., categorical exclusion (CX) determination, environmental assessment (EA), or environmental impact statement
(EIS)]. A total of 382 SRS-related NEPA reviews were conducted in 2010 (see table 3-2). In November 2009, SRS began to post CX determinations on the SRS external website (http://www.srs.gov/general/pubs/ envbul/nepa1.htm) in support of DOE's effort to facilitate NEPA process transparency and openness. By the end of 2010, SRS had posted 203 CX determinations on the website. The following is a listing of major NEPA reviews conducted during 2010, some of which are scheduled to be completed in 2011:

- Supplemental Analysis (SA) for the Savannah River Site High-Level Waste Tank Closure Environmental Impact Statement (DOE/EIS-0303-SA-02) - In this SA, DOE is reviewing the use of current technologies and the waste determination process legislated by Congress to implement DOE's decision to stabilize tanks by filling them with grout. Publication of the SA is expected in late 2011.

- Surplus Plutonium Disposition Supplemental EIS (DOE/EIS-0283-S2) - DOE has announced its intent to modify the scope of this ongoing Supplemental EIS (SEIS) and to conduct additional public scoping. DOE issued its original Notice of Intent (NOI) March 28, 2007. The preferred alternative for the disposition of surplus plutonium was to construct and operate a vitrification facility at SRS. Since that time, DOE has continued to evaluate alternatives for plutonium disposition, and the department's Deputy Secretary has authorized preparation of a conceptual design for a project that would (1) combine the functions of the planned Pit Disassembly and Conversion Facility (PDCF) and the Plutonium Preparation Project (PuP) and (2) install and operate the required equipment to disassemble pits and convert plutonium metals to oxides in the $\mathrm{K}$ Area Complex at SRS. DOE also has determined that disposal of some of the surplus plutonium at its Waste Isolation Pilot Plant (WIPP) in New Mexico is a reasonable alternative. DOE issued a revised NOI July 19, 2010, and will evaluate alternatives for disposition of surplus nonpit plutonium and surplus clean metal and oxide plutonium materials. A summary of all the alternatives DOE will evaluate in the SEIS follows: (1) PDCF Baseline - DOE would construct and operate a stand-alone PDCF facility in F Area; (2) PuP Baseline - DOE would construct and operate the equipment required to prepare nonpit plutonium for either H-Canyon processing or as feed material for the MOX Fuel Fabrication Facility (MFFF); (3) Combination Project in K Area - DOE would construct and operate a facility with combined PDCF and PuP capabilities in K Area; (4) H-Canyon - DOE would use the H-Canyon to 
process surplus plutonium for disposal; (5) Vitrification - DOE would install a vitrification facility with can-in-canister capability in K Area; (6) WIPP - DOE would prepare nonpit plutonium that could not be utilized as MFFF feed material for disposal at WIPP; (7) MFFF feed - PuP capabilities would be used to prepare some additional surplus nonpit plutonium as feed for the MFFF; and (8) DOE will evaluate the impacts of using MOX fuel in reactors operated by the Tennessee Valley Authority at the Sequoyah and Brown's Ferry Nuclear Stations. Additional scoping meetings were conducted in August 2010.

- $\quad$ EIS for the Disposal of Greater-Than-Class-C LowLevel Radioactive Waste (GTCC LLW) (DOE/EIS0375) - In this EIS, DOE will evaluate the impacts of disposing GTCC LLW in a geologic repository, in intermediate-depth boreholes, or in enhanced nearsurface disposal facilities. Candidate DOE sites still being considered at the end of 2010 for these disposal facilities included SRS, Idaho National Laboratory, Los Alamos National Laboratory, WIPP, Nevada Test Site, Oak Ridge, Hanford, and Yucca Mountain. DOE also will consider generic commercial disposal of GTCC LLW at arid and humid locations. Disposal alternatives being considered for SRS include an intermediate-depth borehole facility and an enhanced near-surface facility. Publication of the draft and final EISs is expected in early 2011 and March 2012, respectively. The ROD schedule is uncertain.

- $\quad$ Supplement Analysis (SA): SRS Spent Nuclear Fuel Management FEIS (DOE/EIS-0279) - In this SA, DOE is reviewing the continued use of H-Canyon to process spent nuclear fuel that the department had decided to manage using the melt-and-dilute process. Using this technology, spent nuclear fuel would be melted along with other materials to ensure formulation of a low enriched uranium-aluminum product. No projected approval dates had been established for the SA or amended ROD by the end of 2010 .

- Environmental Assessment for the Proposed Use of SRS Lands for Military Training (DOE/EA-1606) In this EA, DOE will evaluate the potential impacts associated with the proposed use of SRS lands for military training by the U.S. Department of Defense. The purpose of the proposed action is to provide the U.S. Army with greater flexibility in developing training missions and strategies in response to rapidly changing world conditions. Publication of the draft and final EAs is expected in mid and late 2011, respectively.
- $\quad$ Revised Finding of No Significant Impact (FONSI): EA for the Safeguards and Security Upgrades for Storage of Plutonium Materials at the SRS (DOE/ $E A-1538)$ - This revised FONSI, based on previous information and analysis presented in DOE/EA1538, as well as on descriptions of the Container Surveillance and Storage Capability project (CSSC) and the Stabilization and Packaging (S\&P) project in $\mathrm{K}$ Area, determined that replacement of CSSC with the $\mathrm{S} \& \mathrm{P}$ project does not constitute a major federal action significantly affecting the quality of the human environment within the meaning of NEPA. Expected environmental impacts of construction and operation of the proposed S\&P project are less than or equal to those of the CSSC, or are otherwise bounded by the CSSC NEPA analysis. DOE approved the revised FONSI July 30, 2010.

- EIS for the Storage and Management of Elemental Mercury (DOE/EIS-0423) - As directed by the Mercury Export Ban Act of 2008, DOE will evaluate seven sites (including SRS) for the long-term storage of elemental mercury. DOE issued the draft EIS in January 2010, with the public comment period ending March 30. The draft EIS is available at http:// www.mercurystorageeis.com. A public hearing was held March 4 in North Augusta, South Carolina. The final EIS is scheduled to be issued in early 2011. The Waste Control Specialists facility near Andrews, Texas, is the preferred alternative site listed in the draft EIS.

\section{Toxic Substances Control Act}

The Toxic Substances Control Act (TSCA) gives EPA comprehensive authority to identify and control chemical substances manufactured, imported, processed, used, or distributed in commerce in the United States. Reporting and record keeping are mandated for new chemicals and for any chemical that may present a substantial risk of injury to human health or the environment.

Polychlorinated biphenyls (PCBs) have been used in various SRS processes. The use, storage, and disposal of these organic chemicals are specifically regulated under 40 CFR 761, which is administered by EPA. SRS has a well-structured PCB program that complies with this TSCA regulation, with DOE orders, and with site policies.

The site's 2009 PCB document log was completed in full compliance with 40 CFR 761, and the 2009 annual report of onsite PCB disposal activities was submitted to EPA Region 4 in July 2010, meeting applicable requirements. The disposal of nonradioactive PCBs routinely generated at SRS is conducted at EPA-approved facilities within 
the regulatory period. For some forms of radioactive PCB wastes, specifically those contaminated with TRU radionuclides, disposal capacity is not immediately available. Such wastes must remain in long-term storage pending necessary processing and packaging that will allow them to be shipped to WIPP for disposal. These wastes are held in TSCA-compliant storage facilities in accordance with 40 CFR 761.

\section{Federal Insecticide, Fungicide, and Rodenticide Act}

The Federal Insecticide, Fungicide, and Rodenticide Act regulates the application of restricted-use pesticides (RUPs) at SRS through a state-administered certification program. The site complies with these requirements through a written procedure. Extensive revisions of the procedure have been incorporated in recent years to improve the efficient management of the site pesticide application process. In 2010, a sitewide assessment of the pesticide program was conducted to determine if opportunities for pesticide management enhancements exist (such as reductions in toxicity or quantities of pesticides used). The assessment covered pesticide management practices by Savannah River Nuclear Solutions (SRNS) technicians as well as by third-party service providers working at SRS.

All pesticides applied on site are approved by the SRS Pesticide Use Task Group and the SRNS Chemical Management Center (CMC). Usage is documented in the Pesticide Activity Report database, which allows Regulatory Integration and Environmental Services (RI\&ES) personnel to monitor application practices as well as to report total annual chemical inventories or usage to meet Emergency Planning and Community Right-to-Know Act (EPCRA) reporting responsibilities.

\section{Radiation Protection DOE Order $\mathbf{5 4 0 0 . 5}$}

DOE Order 5400.5, "Radiation Protection of the Public and the Environment," specifies radiation dose standards for individual members of the public. The dose standard of 100 mrem per year includes doses a person receives from routine DOE operations through all exposure pathways. To demonstrate compliance with the all-pathway dose standard, SRS conservatively combines the airborne pathway and liquid pathway dose estimates, even though the two doses are calculated for hypothetical individuals residing at different geographic locations.

The highest potential dose to the maximally exposed individual from all pathways (liquid and atmospheric) in 2010 was $0.11 \mathrm{mrem}(0.0011 \mathrm{mSv})$. This dose is 0.11 percent of the DOE dose standard. The 2010 all-pathway dose is about 8 percent less than the 2009 dose of 0.12 mrem $(0.0012 \mathrm{mSv})$.

Nontypical exposure pathways - not included in the standard calculations of the doses to the maximally exposed individual — are considered and quantified separately because they apply to low-probability scenarios, such as consumption of fish caught exclusively from the mouths of SRS streams, or to unique scenarios, such as volunteer deer hunters. During 2010, the maximum dose that could have been received by an actual onsite hunter was estimated at $12.4 \mathrm{mrem}$ $(0.0124 \mathrm{mSv})$, or 12.4 percent of DOE's 100 -mrem allpathway dose standard.

A detailed discussion of this subject may be found in chapter 6, "Potential Radiation Doses."

\section{DOE Order 435.1}

SRS manages low-level, high-level and TRU waste in compliance with DOE Order 435.1, "Radioactive Waste Management," within a number of storage and disposal units. The 2010 annual review of the Performance Assessment (PA) and Composite Analysis (CA) (Reference: Composite Analysis for E-Area Vaults and Saltstone Disposal Facilities, WSRC-RP-97-311, Rev 0, September 1997; Addendum to the Composite Analysis for the E-Area Vaults and Saltstone Disposal Facilities, WSRC-RP-99-00844, September 1999; Performance Assessment and Composite Analysis Maintenance Program FY2008 Implementation Plan, WSRCRP-2008-00534, Rev. 0, May 2008) showed that LLW operations in FY10 were well within the performance envelope analyzed in the PA, CA, and Special Analyses (SA).

Additional details regarding radiological environmental monitoring and surveillance, and potential radiation doses resulting from SRS activities, can be found in chapters 4 ("Effluent Monitoring"), 5 ("Environmental Surveillance"), and 6 of this document.

\section{Air Quality and Protection Clean Air Act}

The Clean Air Act (CAA) of 1970 and the Clean Air Act Amendments (CAAA) of 1990 provide the basis for protecting and maintaining air quality. Though EPA still maintains overall authority for the control of air pollution, regulatory authority for all types of emission sources has been delegated to SCDHEC. Therefore, SCDHEC must ensure that its air pollution regulations are at least as stringent as the federal requirements. This is accomplished through SCDHEC Regulation 61-62, 
"Air Pollution Control Regulations and Standards." The various CAAA titles covered by these SCDHEC regulations are discussed below.

\section{Title V Operating Permit Program}

Under the CAA, and as defined in federal regulations, SRS is classified as a "major source" and, as such, falls under the CAAA Part 70 Operating Permit Program. SCDHEC's Bureau of Air Quality issued SRS its Part 70 Air Quality Permit (TV-0080-0041), February 19, 2003, with an effective date of April 1, 2003. The Title V Operating Permit, which initially expired March 31, 2008, was extended with the September 18, 2007, submittal of an application for renewal, as required by SC R61-62.70. The site expects to receive the new Part 70 Air Permit in 2011. Until SCDHEC renews the permit, SRS will continue to operate in accordance with requirements of the extended permit.

The Part 70 Air Quality Permit regulates both radioactive and nonradioactive toxic and criteria pollutant emissions from approximately 22 nonexempt emission units, with each emission unit having specific emission limits, operating conditions, and monitoring and reporting requirements. The permit also contains a listing, known as the Insignificant-Activities List, identifying approximately 500 SRS sources that are exempt based on insignificant emission levels, or on equipment size or type.

The renewed Title V permit for the D Area Powerhouse (TV-0300-0036) was issued to SRS May 15, 2007, with an effective date of July 1, 2007, and an expiration date of June 30, 2012. In 2007, DOE-SR proposed replacement of the existing $\mathrm{D}$ Area Powerhouse boilers with two new biomass-fired cogeneration boilers more closely aligned with current and future steam demands. This proposed action would allow for decommissioning of the existing D Area Powerhouse prior to its current Title V permit expiring June 30, 2012. SCDHEC issued construction permit No. 0080-0144CA November 12,2008 , for the new biomass cogeneration plant, to be located near F Area. Construction of the plant, which officially got under way with a groundbreaking ceremony November 30, 2009, continued through 2010. SCDHEC issued no revisions to the SRS Part 70 Air Quality Permit (TV-0080-0041) or the 484-D Powerhouse Part 70 Air Quality Permit (TV-03000036) in 2010. Three revisions to the 484-D Powerhouse Part 70 Air Quality Permit (TV-0300-0036) were issued by SCDHEC in 2009 to incorporate two administrative changes and one minor modification to remove insignificant activities.
MFFF - a part of the SRS Nuclear Nonproliferation Program - was issued an air construction permit (00800139CA) August 22, 2006. Construction of the MFFF, which began August 1, 2007, continued throughout 2010. Compliance with the SRS Part 70 Air Quality Permit conditions last was evaluated by SCDHEC March 15, 2010, as part of an Air Compliance Inspection. For results of the evaluation, refer to the "Environmental Audits" section of this chapter, beginning on page 3-16.

\section{Notices of Violation}

SRS received an NOV and an NOAV in 2010 for failure to fully comply with requirements in South Carolina Regulation 61-86.1 ("Standards of Performance for Asbestos Projects"). Additional information about these actions can be found in the "Notice of Violation/Notice of Alleged Violation" section of this chapter (page 3-16).

\section{Accidental Release Prevention Program}

Under Title III of the CAAA, EPA established a program for the prevention of accidental releases of large quantities of hazardous chemicals. As outlined in Section 112(r), any facility that maintains specific hazardous or extremely hazardous chemicals in quantities above specified threshold values must develop a risk management program (RMP). The RMP establishes methods that will be used for the containment and mitigation of large chemical spills.

SRS maintains hazardous and extremely hazardous chemical inventories below the threshold value. This cost-effective approach minimizes the regulatory burden of 112(r) but does not eliminate any liability associated with the general duty clause, as stated in 112(r)(1). No reportable 112(r)-related hazardous or extremely hazardous chemical releases occurred at SRS in 2010.

\section{Ozone-Depleting Substances}

The CAAA mandated significant new air quality standards for the protection of stratospheric ozone. These initiatives directly impacted operations, maintenance, and recordkeeping activities related to ozone depleting substances (ODS) at SRS. First, the CAAA Title V operating permit program (TV-00800041, Condition 4.B.6) requires that SRS comply with the standards for recycling and emissions reduction pursuant to 40 CFR 82 . The permit specifies compliance with the requirements of Subpart B ("Servicing of Motor Vehicle Air Conditioners"), Subpart E ("The Labeling of Products Using Ozone-Depleting Substances"), and Subpart G ("Significant New Alternatives Policy Program"). Accordingly, all large (greater than or equal to 50-pound charge) heating, ventilation, and 
air conditioning/chiller systems leak repair data are reported monthly. Incidental discharges from refrigerant sources at SRS during 2010 totaled 470 pounds.

Additionally, the Title $\mathrm{V}$ operating permit also specifies that SRS comply with the requirements of halon emissions reduction and recycling found in 40 CFR 82, Subpart H ("Halon Emissions Reduction"). Halon is used as a fire suppression agent; therefore, the SRS Fire Department (SRSFD) is responsible for providing halon fire suppression equipment at the site. SRSFD personnel maintain and recharge halon-containing equipment, and manage the national halon repository (Savannah River Halon Repository). Halon is maintained at this repository to support existing missions at SRS for the life of the missions. The repository also maintains halon supplies for other sites in the DOE complex.

According to the SRS Halon Management Plan (FESR-G-00120, November 16, 2005), all halon systems in service at SRS are scheduled to remain in service for the life of SRS's existing missions. As missions cease, halon will be recovered, recycled, and stored at the SRS repository in support of continuing missions. When stored halon exceeds the amount needed for support of SRS and other DOE sites, the excess is shipped to the U.S. Department of Defense (DOD), or offered to the General Services Administration as excess. SRS continues to phase out its use of halon as part of an overall goal to eliminate halon use in the United States.

The SRSFD details the total halon inventory at SRS in its annual "Halon Report" to DOE. A successful audit of the halon inventory was conducted during 2010. As of December 31 , there were approximately 52,422 pounds in the SRS inventory, including 19,704 pounds in 85 installed fire suppression systems, and 7,030 pounds of unprocessed Halon stored in original containers. The balance, 25,688 pounds of Halon, has been processed and is stored on site in 1-ton bulk containers. In addition to the SRS inventory, halon totaling 32,718 pounds was maintained in the national halon repository at SRS.

\section{Air Emissions Inventory}

SCDHEC Regulation 61-62.1, Section III ("Emissions Inventory"), requires compilation of an air emissions inventory to locate all sources of air pollution and to define and characterize the various types and amounts of pollutants. To demonstrate compliance, SRS personnel in 1993 conducted the initial comprehensive air emissions inventory, which identified approximately 5,300 radiological and nonradiological air emission sources. Source operating data and calculated emissions from 1990 were used initially to establish the SRS baseline emissions and to provide data for air dispersion modeling.

Regulation 61-62.1, Section III, was revised in 2010. The revision will require the site to begin annual submittal of its air inventories for both operating permits, TV0080-0041 and TV-0080-0044, beginning with CY10 emissions. The site submitted CY09 emissions for the D Area Powerhouse (TV-0080-0044) to SCDHEC on March 24, 2010. The site was not required to submit 2009 emissions under its other operating permit (TV0090-0041); however, due to the change in regulations it will begin annual submittals of air emissions beginning with CY10 emissions.

During 2010, the site collected CY09 operating data for permitted and other sources in accordance with SRS procedures and guidelines. Because data collection for all SRS sources begins in January for the preceding year, and requires up to 6 months to complete, the 2010 site environmental report contains emissions data for CY09. These data were used to generate the site's Title V Permit renewal application. Compilation of 2010 data will be completed in 2011 and documented in the SRS Environmental Report for 2011.

\section{National Emission Standards for Hazardous Air Pollutants}

The National Emission Standards for Hazardous Air Pollutants (NESHAP) is a CAA-implementing regulation that sets air quality standards for air emissions containing hazardous air pollutants, such as radionuclides, benzene, and asbestos.

\section{NESHAP Radionuclide Program}

The current list of 187 hazardous air pollutants includes all radionuclides as a single item. Regulation of these pollutants has been delegated to SCDHEC; however, EPA Region 4 continues to regulate some aspects of NESHAP radionuclides.

NESHAP Radionuclide Program Subpart H of 40 CFR 61 was issued December 15, 1989, after which an evaluation of all air emission sources was performed to determine compliance status. DOE-SR and EPA Region 4 signed a Federal Facility Compliance Agreement (FFCA) October 31, 1991, providing a schedule to bring SRS's emissions monitoring into compliance with regulatory requirements. The FFCA was officially closed - and the site declared compliant-by EPA Region 4 May 10, 1995. Subpart H was revised by EPA 
September 9, 2002, with an effective date of January 1,2003 . This revision added inspection requirements for existing SRS sources and allowed the use of ANSI N13.1-1999 for establishing monitoring requirements. SRS is performing all required inspections, has monitoring systems compliant with the regulation, and remains in compliance with Subpart H of 40 CFR 61.

During 2010, the maximally exposed individual effective dose equivalent, calculated using the NESHAP-required CAP88 computer code, was estimated to be $0.05 \mathrm{mrem}$ $(0.005 \mathrm{mSv})$, which is 0.5 percent of the 10 mrem per year $(0.10 \mathrm{mSv}$ per year) EPA standard (chapter 6).

SRS compliance with 40 CFR 61, Subpart H ("National Emission Standards for Emissions of Radionuclides Other Than Radon from Department of Energy Facilities") last was evaluated by SCDHEC in June 2008 as part of a Title $\mathrm{V}$ radiological NESHAP inspection. SCDHEC did not conduct a Subpart H inspection at SRS in 2010 .

\section{NESHAP Nonradionuclide Program}

SRS uses many chemicals identified as toxic or hazardous air pollutants, but most of them are not regulated under the CAA or under federal NESHAP regulations. Except for asbestos, SRS facilities and operations do not fall into any of the "categories" listed in the original subparts. Under Title III of the CAAA, EPA in December 1993 issued a final list of hazardous air pollutant-emitting source categories potentially subject to maximum achievable control technology (MACT) standards; SRS currently is not impacted by any promulgated MACT standards for source categories.

\section{NESHAP Asbestos Abatement Program}

SRS began its asbestos abatement program in 1988 and continues to manage asbestos-containing material (ACM) by "best management practices." Site compliance in asbestos abatement, as well as in renovations and demolitions, falls under SCDHEC and federal regulations, including South Carolina Regulation 61-86.1 ("Standards of Performance for Asbestos Projects") and 40 CFR 61, Subpart M ("National Emission Standards for Hazardous Air Pollutants Asbestos"). An SRS procedure (3Q, 4.14, “Asbestos Management Program") provides site personnel and contractors applicable guidelines to ensure compliance with state and federal requirements.

SCDHEC finalized extensive revisions to Regulation
61-86.1 during 2008. The change that most affected SRS was a requirement that mandated a follow-up analysis of suspect ACM using transmission electron microscopy (TEM) of at least one of three bulk samples should all three samples test negative for the presence of asbestos when using customary polarized light microscopy. RI\&ES personnel secured a laboratory to perform the TEM analyses, thus enabling the site to comply with the new requirement. The site asbestos procedure was revised in 2010 to include considerably more information on how to properly dispose of ACM. Also, the SRS Asbestos Working Group (AWG) was formed to develop and share best asbestos management practices across the site. The AWG includes asbestos planners, supervisors, and workers from a number of site organizations.

In addition to numerous project reviews, site walkdowns, and instructional class meetings to inform site personnel of current asbestos management regulations, SCDHEC Asbestos Section management presented two "Asbestos 101 " classes at SRS. The classes were attended by approximately 75 site employees.

SRS personnel removed and disposed of 764 linear feet and 470 square feet of friable (regulated) ACM, and 581 linear feet, 144,238 square feet, and 6 cubic feet of nonfriable (unregulated) ACM during 2010. Approximately 240 SRS asbestos specialists are certified by SCDHEC in various disciplines (planners, supervisors, inspectors, workers, etc.).

Radiologically-contaminated asbestos waste was disposed of in 2010 at the SRS E-Area low-level vaults, engineered trenches, and slit trenches, which are authorized by SCDHEC as asbestos waste disposal sites. Nonradiological asbestos waste was disposed of at the Three Rivers Solid Waste Authority Landfill and the Construction and Demolition (C\&D) Landfill (632-G), both of which also are SCDHEC-approved asbestos waste landfills.

\section{Water Quality and Protection Clean Water Act}

\begin{abstract}
National Pollutant Discharge Elimination
System The Clean Water Act (CWA) of 1972 created the National Pollutant Discharge Elimination System (NPDES) program, which is administered by SCDHEC under EPA authority. The program is designed to protect surface waters by limiting releases of effluents into streams, reservoirs, and wetlands.
\end{abstract}

SRS had four NPDES permits in 2010: 
- Two permits for industrial wastewater discharges (SC0047431, which covered the D-Area Powerhouse, and SC0000175, which covered the remainder of the site).

- Two general permits for stormwater discharges (SCR000000 for industrial and SCR100000 for construction). ${ }^{1}$ Permit SCR000000 expired December 31, 2010; renewal of the permit became effective January 1, 2011.

The site also had one no-discharge permit for land application of biosolids (ND0072125). This permit was renewed in 2010 and is applicable for another 10 years. More information about SRS's NPDES permits can be found in chapter 4 .

The results of monitoring for compliance with the industrial wastewater discharge permit at SRS were reported to SCDHEC in the site's monthly discharge monitoring reports, as required by the permit. SRS had zero permit limit exceptions during 2010, a compliance record that has been attained only one other time (2007).

SCDHEC generally conducts an unscheduled "NPDES 3560 Compliance Sampling Inspection" of the site's permitted outfalls annually. The 2010 inspection, conducted in March, resulted in a "Satisfactory" rating - the highest achievable.

Outfalls covered by the industrial stormwater permit (SCR000000) were reevaluated in 2009. This resulted in the development of a new sampling plan implemented in 2010. No new issues were identified in 2010. Stormwater outfall sampling results appear in an effluent monitoring data table 4-9) in the "Environmental Data/Maps 2010" section of the CD housed inside the back cover of this report.

Dredge and Fill; Rivers and Harbors The CWA, Section 404, "Dredge and Fill Permitting," as amended, and the Rivers and Harbors Act (RHA) of 1899, Sections 9 and 10, "Construction Over and Obstruction of Navigable Waters of the United States," protect U.S. waters from dredging/filling and construction activities by the permitting of such projects. Dredge-and-fill operations in U.S. waters are defined, permitted, and controlled through implementation of federal regulations in 33 CFR and 40 CFR.

\footnotetext{
SRS and SCDHEC personnel worked together on an agreement letter dated October 31, 2005, that helped ensure SRS compliance with the 2005 Industrial Stormwater General Permit by requiring implementation of best management practices at certain stormwater outfalls.
}

In 2010, SRS had five open permits under the Nationwide Permits (NWPs) program (general permits under Section 404), and one open permit under the RHA of 1899 , Section 10, as follows:

- Dam construction on an unnamed tributary to Fourmile Branch for the Mixed Waste Management Facility Groundwater Interim Measures project was completed in 2000 under NWP 38, "Hazardous Waste Cleanup." However, mitigation for the impact to wetlands was still pending in 2010 and must be addressed before the permit can be considered closed. SRNS has requested approval from DOE to use wetland mitigation bank credits to satisfy the mitigation issue and close the permit.

- A minor discharge of material for research purposes was authorized in May 2008 under NWP 18, "Minor Discharges. The material was placed in Steel Creek below the S.C. Highway 125 bridge and used by the Savannah River National Laboratory (SRNL) as part of a remediation research project evaluating active caps in streams to remediate contaminants. An active cap is one that actively binds or sequesters contaminants - as opposed to a passive cap, which simply covers contaminants. The cap in this research project consisted of combinations of apatite, sand, organoclay, and a sugar-based polymer. The research was concluded in 2010, and the research site is being restored to its original condition.

- $\quad$ SRS initiated a project during 2009 to dredge sediments out of the $681-3 \mathrm{G}$ and $681-5 \mathrm{G}$ pumphouse canals to allow for better flow to the water intake of each pumphouse. An RHA of 1899 Section 10 permit, (SAC-2008-1156) was obtained from the U.S. Army Corps of Engineers (COE) March 24, 2009 , to allow the dredging work to begin. Both canals were successfully dredged and returned to their original design. Maintenance dredging of accumulated sediments in the $681-5 \mathrm{G}$ canal was required in December 2010. The Section 10 permit will remain open until March 31, 2014, to allow for additional maintenance dredging as required.

- SRNL initiated a remediation experiment project in March 2010 in Tims Branch. The installation of lysimeters in the wetlands near Tims Branch was covered by NWP 5, "Scientific Measurement Device." The lysimeters were used in an experiment to evaluate the effect of a mixture of amendments (apatite, organoclay, and cross-linked biopolymers) for the remediation of metals in Tims Branch soils.

- ACP initiated a well installation - covered by NWP 5-in a wetland near Upper Three Runs in December 2010 to investigate groundwater near the Nonradioactive Waste Disposal Facility (Sanitary 
Landfill, 740-G). The well was required to investigate a potential plume coming from the landfill.

- A road realignment project - funded by American Reinvestment and Recovery Act (ARRA) monieswas determined in February to have impacted a wetland in the ditch on the east side of Highway 125. The project, initiated to realign Highway 125 at its Road 2 intersection, was covered under NWP 14, "Linear Transportation Projects." Because of the wetland impact, it also required a Section 404 permit. Mitigation for the impact was achieved by using credits from the SRS wetland mitigation bank. The realignment project was completed in April 2010.

Water Quality Certification Section 401, "Water Quality Certification," of the CWA is administered by SCDHEC to ensure the maintenance of water quality during dredge-and-fill projects. On December 4, 2008, a water quality certification (WQC), P/N 2008-1156-6IJ, was issued to Washington Savannah River Company for the sediment dredging project of the $681-3 \mathrm{G}$ and $681-5 \mathrm{G}$ pumphouse canals. This certification was transferred to SRNS January 14, 2009. The WQC-a prerequisite for the Section 10 permit required by the COE for this project-remains in effect for this project until December 4, 2011.

Construction in Navigable Waters SCDHEC Regulation 19-450, "Permit for Construction in Navigable Waters," protects South Carolina's navigable waters. The only state navigable waters at SRS are Upper Three Runs Creek (through the entire site), Lower Three Runs Creek (upstream to the base of the PAR Pond Dam), and the Savannah River (along the site's southwestern border).

A navigable waters permit (P/N 2008-1156-6IJ) was issued to Washington Savannah River Company December 4, 2008, for the sediment dredging project of the $681-3 \mathrm{G}$ and $681-5 \mathrm{G}$ pumphouse canals. The permit - transferred to SRNS January 14, 2009—was issued by SCDHEC simultaneously with the WQC, and remains in effect for this project until December 4, 2011.

\section{NPDES Permit Exceedances}

In 5,059 sample analyses (including flow measurements and no-flow designations) performed during 2010, no permit exceedance was observed.

\section{Safe Drinking Water Act}

The federal Safe Drinking Water Act (SDWA) was enacted in 1974 to protect public drinking water supplies. SRS domestic water is supplied by groundwater sources. The A Area and D Area drinking water facilities are actively regulated by SCDHEC, while the remaining smaller water systems receive a reduced level of regulatory oversight. The K Area System was incorporated into the A Area system in 2010, and removed from SCDHEC's water system inventory.

Samples are collected and analyzed periodically by SRS and SCDHEC to ensure that all site domestic water systems meet SCDHEC and EPA bacteriological and chemical drinking water quality standards. All samples collected in 2010 met these standards.

The water system in A Area was sampled under the state Lead and Copper Rule in 2010, and was found to be in compliance with SCDHEC action levels for lead and copper in the 90th percentile.

\section{Other Environmental Statutes EPCRA/SARA Title III}

EPCRA (enacted in 1986) requires facilities to notify state and local emergency planning entities about their hazardous chemical inventories and to report releases of hazardous chemicals. The Pollution Prevention Act of 1990 expanded the EPCRA-mandated Toxic Chemical Release Inventory-i.e., Toxics Release Inventory (TRI) — report to include source reduction and recycling activities.

\section{Executive Order 12856}

Executive Order 12856, "Federal Compliance with Right-to-Know Laws and Pollution Prevention Requirements," requires that all federal facilities comply with right-to-know laws and pollution prevention requirements. SRS complies with the appropriate reporting requirements for EPCRA, and incorporates the applicable TRI chemicals into its pollution prevention efforts (table 3-3).

\section{Chemical Inventory Report (Tier II)}

Under Section 312 of EPCRA, SRS completes an annual Tier II Chemical Inventory Report for all hazardous chemicals present at the site in excess of specified quantities during the calendar year. Hazardous chemical storage information is submitted to state and local authorities by March 1 for the previous calendar year.

\section{Toxics Release Inventory Report (Form R)}

Under Section 313 ("Toxic Chemical Release Inventory") of EPCRA, SRS must file an annual TRI report by July 1 for the previous year. SRS calculates 


\begin{tabular}{|c|c|c|}
\hline \multirow{2}{*}{$\begin{array}{r}\text { Table 3-3 } \\
\text { EPCRA } \\
\text { CITATION }\end{array}$} & \multicolumn{2}{|c|}{$\begin{array}{l}\text { SRS Reporting Requirements } \\
\text { under "Federal Compliance with } \\
\text { Right-to-Know Laws and Pollution } \\
\text { Prevention Requirements" } \\
\text { (Executive Order 12856) }\end{array}$} \\
\hline & $\begin{array}{c}\text { Activity } \\
\text { Regulated }\end{array}$ & $\begin{array}{c}\text { Reported } \\
\text { In } 2010\end{array}$ \\
\hline $302-303$ & $\begin{array}{l}\text { Planning } \\
\text { Notification }\end{array}$ & $N A^{a}$ \\
\hline 304 & $\begin{array}{l}\text { Extremely } \\
\text { Hazardous } \\
\text { Substances } \\
\text { Release Notification }\end{array}$ & $N A^{a}$ \\
\hline $311-312$ & $\begin{array}{l}\text { Material Safety } \\
\text { Data Sheet / } \\
\text { Chemical Inventory }\end{array}$ & Yes \\
\hline 313 & $\begin{array}{l}\text { Toxic Release } \\
\text { Inventory Reporting }\end{array}$ & Yes \\
\hline
\end{tabular}

${ }^{\text {a }}$ Did not exceed reporting threshold

chemical releases to the environment for each regulated chemical that exceeds its established threshold value and (in addition to other inventory data sets) reports the release values to EPA on Form R of EPCRA Section 313. Threshold values are those quantities of regulated chemicals (as defined by EPCRA Section 313) above which additional reporting is required using Form R.

Form R for 2009 was submitted electronically to EPA July 1, 2010. SRS reported the following chemicals that exceeded their thresholds: barium, chlorine, chromium, copper, fluorine, formic acid, hydrochloric acid, lead, mercury, nickel, nitrate, nitric acid, sodium nitrite, sulfuric acid, asbestos, and zinc. (NOTE: The term "exceeded" in an EPCRA context does not indicate a violation. Per EPA regulations, SARA chemical limits are established, and reporting requirements are based on these threshold values.) Specific details, including release amounts and detailed information about toxic release inventory reporting, can be viewed on the EPA website at http://www.epa.gov/tri/tridata.

SRS exceeded the 2009 reporting threshold for friable (regulated) asbestos due to extensive demolition and deactivation activities performed under the ARRA scope; this triggered Form $\mathrm{R}$ reporting requirements.

\section{Endangered Species Act}

The Endangered Species Act of 1973, as amended, provides for the designation and protection of wildlife, fish, and plants in danger of becoming extinct. The act also protects and conserves the critical habitats on which such species depend.

Several threatened and endangered species exist at SRS, including the wood stork, the red-cockaded woodpecker, the shortnose sturgeon, the pondberry, and the smooth purple coneflower. Although the bald eagle no longer is on the endangered species list, it still is protected under the Bald and Golden Eagle Protection Act. Programs are in place on site to enhance the habitat and survival of such species.

During 2010, as part of the U.S. Department of Agriculture Forest Service-Savannah River (USFSSR) Natural Resource Management Plan, USFS-SR personnel developed four biological evaluations for timber-related activities, reviewed the evaluations and determined that associated management actions would not adversely impact threatened or endangered species.

\section{National Historic Preservation Act}

The National Historic Preservation Act (NHPA) of 1966, Section 106, governs archaeological and historical resources. SRS ensures that it is in compliance with the NHPA through several processes. The Cold War Programmatic Agreement and "SRS's Cold War Built Environment Cultural Resource Management Plan" are being implemented. The site's artifact selection team-which includes DOE, SRNS, and the University of South Carolina's Savannah River Archaeological Research Program (SRARP) - meets monthly and is responsible for overseeing the selection, collection, and curation of Cold War-era artifacts from buildings prior to decommissioning and demolition activities.

SRS also helps ensure that it remains in compliance with NHPA through its Site Use Program. All locations being considered for activities such as construction are evaluated by SRARP personnel to ensure that archaeological or historic sites are not impacted. Reviews of timber compartment prescriptions include surveying for archaeological resources and documenting areas of importance with regard to historic and prehistoric significance.

The following information is summarized from the "Annual Review of Cultural Resources Investigations by the Savannah River Archaeological Research Program, Fiscal Year 2010" [SRARP, 2010].

SRARP personnel reviewed 57 site-use permit application packages during FY10, of which 26 proposed land modifications resulted in the need to survey 756 acres (46 percent) of the total survey coverage for FY10. 
The remaining site-use packages were found to have no activities of significant impact in terms of the NHPA. SRARP personnel also surveyed 871 acres (54 percent) of the total survey area coverage in 2010 to support onsite forestry activities.

Forty-one surveys were conducted in FY10, totaling 1,627 acres and consisting of 26 Site-Use Application Surveys and 15 Timber Compartment Prescription Surveys. During these surveys, a total of 3,866 shovel test pits were dug. These investigations identified eight new archaeological sites - and resulted in revisits to 119 previously recorded sites for cultural resources management within the 1,627 acres.

In compliance with the NHPA, artifacts recovered through daily compliance activities and the analyses of these artifacts must be curated. SRARP curated 21,279 artifacts during FY10 from Flamingo Bay, Frierson Bay, and Johns Bay excavations. Of these curated artifacts, 1,648 were from compliance-related excavations; 15,213 from Flamingo Bay; 1,009 from Frierson Bay, and 3,409 from Johns Bay.

\section{Migratory Bird Treaty Act}

The Migratory Bird Treaty Act of 1918 (MBTA) is the domestic law that governs the protection of migratory birds, including eggs and nests. The MBTA prohibits the taking, possession, import, export, transport, selling, purchase, or barter of - or offering for sale, purchase or barter-any migratory bird or its eggs, parts, and nests, except as authorized under a valid permit.

In 2010, several nests protected under the MTBA were found in large mobile equipment located at the Portable Equipment Commodity Center (PECMC). The equipment was barricaded until the hatchlings fledged or the nests were determined by SRNS, with concurrence by the U.S. Fish and Wildlife Service to no longer be viable.

\section{DOE Orders 450.1A, 430.2B / Executive Order 13514 Summary of EMS Programs}

DOE Orders 450.1A, "Environmental Protection Program," and 430.2B, "Departmental Energy, Renewable Energy and Transportation Management," describe DOE's requirements and responsibilities for implementing Executive Order (EO) 13423, "Strengthening Federal Environmental, Energy and Transportation Management.” EO 13423 directs each federal agency to use an Environmental Management System (EMS) as the framework to implement, manage, measure, and continually improve upon sustainable environmental, energy, and transportation practices. The EMS program at SRS is described in the EMS Description Manual (G-TM-G-00001, Rev. 6).

\section{Performance}

EMS goals are established annually, and SRS made significant progress toward energy, transportation, and sustainability performance goals in 2010. Highlights of the year's progress include

- the achievement of a 20.6-percent energy reduction in FY10 compared with FY03, against a goal of 30percent reduction from 2003 to 2015

- $\quad$ a reduction in potable water consumption by 11 percent between FY09 and FY10 (despite increases in staffing and projects associated with ARRA activities), against a goal of 16-percent reduction from FY07 to FY15.

- an increase of 26 percent in ethanol use versus gasoline in FY10 compared with FY05, versus a goal of a 10-percent annual increase in fleet alternative fuel consumption (SRS experienced a 350-percent increase in such usage between FY00 and FY10.)

- the achievement of LEED-Gold certification for the MOX Services Administration Building

Additional information on these and other sustainability programs may be found in chapter 2 ("Environmental Management System") and in the SRS FY11 Site Sustainability Plan, issued in December 2010.

\section{E013514 Greenhouse Gas Reductions}

Executive Order 13514, "Federal Leadership in Environmental, Energy, and Economic Performance," established greenhouse gas (GHG) reduction goals of 28 percent for Scope 1 and 2 items (power generation facilities) and 13 percent for Scope 3 items (business and employee travel) by 2020 from the 2008 baseline. Reducing energy intensity, continuing construction of a Biomass Cogeneration Facility and several satellite biomass plants, and increasing the use of alternative fuels and alternative-fuel vehicles are some of the ways SRS made progress toward this goal in 2010. Details of this progress against sustainability goals are provided in chapter 2 .

\section{Sustainability and Pollution Prevention}

The SRS Pollution Prevention/Waste Minimization (P2/ WMin) Program continued to achieve significant results in 2010. All required site waste generators demonstrated active participation in the program through documented pollution avoidance and/or direct mission support 
activities for site recycling.

The P2/WMin Program met all DOE and regulatory agency reporting requirements. Program accomplishments during 2010 included the following:

- The documentation of $23 \mathrm{P} 2$ projects resulting in a DOE-SR-approved annualized avoidance of 838 cubic meters of hazardous and radioactive waste (Site contractors exceeded their FY10 waste avoidance performance goal of 399 cubic meters by about 110 percent; annual cost avoidance resulting from the documented $\mathrm{P} 2$ projects was $\$ 1.5$ million.)

- The announcement by DOE-EM (in FY10) that SRS won a 2009 Environmental Sustainability Best in Class award for the Constructed Wetlands Reduce Environmental Impacts project and 2009 Best in Class Honorable Mention Award for the Detoxification of Outfall Water Using Natural Organic Matter project, with the latter also winning a DOE EStar Honorable Mention Award (SRS was represented at the awards ceremony, which also was attended by DOE Secretary Dr. Steven Chu.)

- The redistribution by CMC of 84,773 pounds of excess chemicals (avoiding \$1.2 million in waste and acquisition costs)

- The shredding/recycling of 594 metric tons of wood waste, and the diversion from the C\&D Landfill $(632-\mathrm{G})$ of 1,335 metric tons of scrap metal and 114 metric tons of scrap furniture

SRS participates in EPA voluntary P2 Programs by maintaining its EPA Waste Wise and EPA National Partnership for Environmental Priorities (NPEP) memberships. SRS exceeded its NPEP goal for the recycle of DOE-suspension lead by over 500 percent. In FY10, 225,000 lbs of DOE moratorium and radioactive contaminated lead was shipped to a vendor for recycling into products approved by the DOE metals moratorium. Recycling provides a costeffective and environmentally preferable option for this stream, versus disposal as RCRA hazardous and radioactive waste.

SRS continued its participation in the Federal Electronic Reuse and Recycle Campaign in 2010, reporting 139,078 pounds of electronics recycled and reused for the contest period.

The site's sanitary municipal solid waste program managed more than 150,000 metric tons of materials in FY10. Thirty-nine percent (1,022 metric tons) of the routine (office-type) sanitary waste stream was recycled via the North Augusta Material Recovery Facility, exceeding the 35 -percent performance objective for this waste stream. Also recycled was 19 percent $(3,188$ metric tons) of the total routine and industrial streams, excluding $C \& D$ waste.

The SRS pollution prevention team supported P2 awareness in 2010 on site and in the local community, as follows:

- Onsite awareness was increased through online articles and general employee and job-specific training.

- $\quad$ SRNS provided a financial donation and voluntary support for the North Augusta Kids Earth Day, which hosted more than 25 separate exhibits to educate and share with the 1,200-plus attendees.

- The P2 Program provided volunteer support and student handouts for the Central Savannah River Area (CSRA) Environmental Science Education Cooperative's (ESEC) ECOMEET event at Thurmond Lake. The event included 29 middle school teams from Georgia and South Carolina competing in a day-long, hands-on environmental education challenge.

- The P2 Program supported the ESEC CSRA Environmental Teacher of the Year Award ceremony in Augusta, Georgia.

- SRNS submitted an award nomination to the NPEP for the recycling of DOE-suspension lead. SRS exceeded its NPEP goal by more than 500 percent.

- SRNS submitted a nomination on behalf of DOESR to the 2009 South Carolina Recycle Guys Awards Program in the federal facilities category.

- $\quad$ SRS Earth Day support included (1) providing photos with captions for posters that DOE-HQ used to highlight winning Environmental Sustainability projects displayed during Earth Day week, (2) providing four articles to the InSite OnLine publication to increase employees' environmental awareness, and (3) presenting a breakout session describing SRS Solid Waste Management facilities and pollution prevention at the Health/Safety/Environmental Blitz at SRS.

\section{EO 11988/11990 Floodplain Management/ Wetlands}

Under 10 CFR 1022 ("Compliance with Floodplains and Wetlands Environmental Review Requirements"), DOE establishes policies and procedures for implementing its responsibilities in terms of compliance with Executive Orders 11988 ("Floodplain Management") and 11990 ("Protection of Wetlands"). Part 1022 includes DOE policies regarding the consideration of floodplains/ wetlands factors in planning and decision making. It 
also includes DOE procedures for identifying proposed actions involving floodplains/wetlands, providing early public reviews of such proposed actions, preparing floodplains/wetlands assessments, and issuing statements of findings for actions in floodplains. A floodplains/ wetlands assessment was developed in 2010 to support a NEPA evaluation for the installation of a temporary road for access to the toe of the earthen cap over the waste unit on the west side of $\mathrm{T}$ Area. The road also was to provide access for cap maintenance and to a monitoring well in the area. The scope of the project was changed to make the road permanent, and the floodplains/wetlands assessment is being revised to support this change.

\section{Other Environmental Issues/ Actions}

\section{Lawsuits}

SRS was not involved in any active environmental lawsuits during 2010.

\section{SRS as Potentially Responsible Party in Superfund Cleanup}

Alternate Energy Resources, Inc., operated a commercial hazardous waste storage and treatment facility in Augusta, Georgia, until 2000, when the facility was abandoned and the owners declared bankruptcy. The facility was placed on the National Priorities List (NPL) in 2006. Nonradioactive SRS and DOE waste was processed at this facility; as a result, EPA named SRS one of 50 potentially responsible parties in the cleanup of this location.

\section{Notice of Violation / Notice of Alleged Violation}

SRS received an NOV and an NOAV in 2010 under the Clean Air Act for asbestos management issues. The two regulatory actions were issued as follows:

- On January 14, SCDHEC issued an NOV to SRNS for dismantling a carport outside the permitted time period for the activity. The demolition license was valid from May 26 to June 29, 2009; the demolition activity occurred July 6, 2009.

- On November 19, SCDHEC issued an NOAV to SRNS for demolishing a utility shed without (1) completing an asbestos building inspection, (2) notifying SCDHEC within 10 days of the demolition, (3) obtaining a demolition license prior to the demolition activity, and (4) removing ACM prior to conducting the demolition activities.

Because SRNS voluntarily implemented extensive corrective actions to address the violations, no penalties or findings were assessed for either the NOV or NOAV.

NOVs/NOAVs received in 2010 and the four preceding years (with dates included for 2010) are summarized in table 3-4.

\section{Environmental Occurrences}

The Site Item Reportability and Issues Management (SIRIM) program, mandated by DOE Order 232.1A ("Occurrence Reporting and Processing of Operations Information"), is designed to ". . . establish a system for reporting of operations information related to DOEowned or -operated facilities and processing of that information to provide for appropriate corrective action ...." It is the intent of the order that DOE be "... kept fully and currently informed of all events which could (1) affect the health and safety of the public; (2) seriously impact the intended purpose of DOE facilities; (3) have a noticeable adverse effect on the environment; or (4) endanger the health and safety of workers."

Of the 107 SIRIM-reportable events at SRS in 2010, four involved allegations of violations, all of which were categorized as environmental. Two of these were an NOV and an NOAV related to asbestos management (see previous section). Another involved 200-300 gallons of fuel oil that leaked from a faulty valve on a tank, and a fourth was for the discharge of less than 5 gallons of oil into a river water canal via a sump pump following a small spill.

\section{Environmental Audits}

The SRS environmental program is overseen by a number of organizations, both outside and within the DOE complex. In 2010, the site's environmental appraisal program again consisted of self and independent assessments. The program ensures the recognition of noteworthy practices, the identification of performance deficiencies, and the initiation and tracking of associated corrective actions until they are satisfactorily completed. The primary objectives of the assessment program are to ensure compliance with regulatory requirements and to foster continuous improvement. The program - an integral part of the site's Integrated Safety Management System - supports the SRS EMS, which continues to meet the guidelines of International Organization for Standardization Standard 14001. (ISO 14000 is a family of voluntary environmental management standards and guidelines.) The Site Tracking, Analysis, and Reporting (STAR) system is a database used for scheduling selfassessments, as well as for (1) documenting their 
Table 3-4 NOV/NOAV Summary, 2006-2010

\begin{tabular}{|lccccc|}
\multicolumn{1}{r}{ Program Area } & $\mathbf{2 0 1 0}$ & $\mathbf{2 0 0 9}$ & $\mathbf{2 0 0 8}$ & $\mathbf{2 0 0 7}$ & $\mathbf{2 0 0 6}$ \\
\hline CAA & 2 & 0 & 1 & 0 & 0 \\
CWA & 0 & 0 & 2 & 0 & 2 \\
RCRA & 0 & 0 & 0 & 0 & 0 \\
CERCLA & 0 & 0 & 0 & 0 & 0 \\
Others & 0 & 0 & 0 & 0 & 0 \\
Total Violations & $\mathbf{2}$ & $\mathbf{0}$ & $\mathbf{3}$ & $\mathbf{0}$ & $\mathbf{2}$ \\
\hline
\end{tabular}

results and any issues or concerns identified, (2) tracking corrective actions to closure, and (3) trending accumulated data for process improvement. DOE-SR conducted 305 environmental protection functional area assessments in 2010 .

SRNS also conducted several environmental programlevel assessments in 2010. The self-assessment titles, the environmental topical areas (in parentheses), and brief summaries of these assessments follow.

- Surface Water Quality-Facility Permitting (Industrial Wastewater Treatment) - This self assessment was conducted from August 11September 30. The purpose was to evaluate the SRS industrial wastewater treatment program against the SCDHEC Industrial Wastewater Permitting Program, including wastewater treatment plant (and associated collection system) design, operation, maintenance, permitting and closeout. The assessment, which included document/procedure reviews and interviews with engineering and environmental compliance personnel, resulted in three findings and five opportunities for improvement (OFIs). Corrective actions, including revisions to site- and facility-level procedures, were identified and initiated — and are in progress or completed.

- Toxic and Chemical Materials - Pesticides - This self-assessment was conducted May 8 through September 30. The objective was to determine if current pesticide storage, application, and disposal practices adhered to the SRS pesticide procedure (3Q, 8.1, "Federal Insecticide, Fungicide and Rodenticide Act Compliance for Use of Pesticides"). Pesticide application practices were reviewed to evaluate conformance to SRS CMC requirements. SCD-4 Environmental Protection Functional Area 4, 2.5.3 ("Management and Control of Pesticides"), Criteria 2.5.3.1 (manufacturer's labeling), 2.5.3.2 (pesticide registration), and 2.5.3.3 (pesticide storage) provided the performance objectives that were considered. The assessment identified 13 OFIs and three findings. Corrective actions for the observations were identified and initiated, and are in progress or completed.

- Domestic Water Systems - SRS domestic water systems are in "good condition" overall, and "operating in compliance with the State Primary Drinking Water Regulations," according to a September 1 inspection of the systems by RI\&ES and Infrastructure Services personnel. The inspection covered the site's A Area, D Area, PAR Pond Lab, L Area Fire Station, and Central Sanitary Waste Treatment Facility water systems. The wells, treatment systems, and storage tanks supporting each of the systems were examined - as were logbooks and round sheets. Recommendations from the inspectors focused primarily on housekeeping matters, including tank refinishing/repainting and grass cutting. The final inspection report indicated that the "overall housekeeping at the treatment plants is good, and efforts should remain to keep it this way."

SCDHEC and EPA personnel conducted external inspections and audits of the SRS environmental program for regulatory compliance. Routine audits and the resulting noncompliances for the past five years are summarized in table 3-5. Agency representatives performed several comprehensive compliance inspections and audits in 2010, as follows:

- RCRA Compliance Evaluation Inspection - The RCRA compliance evaluation inspection was conducted by SCDHEC August 2-6. The November 3 SCDHEC inspection report letter noted that no violations were found.

- Annual Underground Storage Tank InspectionSCDHEC inspected 12 of the site's 19 underground storage tanks (USTs) September 28. All were found to be in compliance with applicable regulations for the eighth straight year. 
Table 3-5 Routine Environmental External Audit and Inspection Summary

\begin{tabular}{|c|c|c|c|c|c|c|}
\hline \multirow{2}{*}{ Audit } & \multirow{2}{*}{ Frequency } & \multicolumn{5}{|c|}{ Noncompliances } \\
\hline & & 2010 & 2009 & 2008 & 2007 & 2006 \\
\hline RCRA CEI & Annually & 0 & 0 & 0 & 0 & 0 \\
\hline UST Inspection & Annually & 0 & 0 & 0 & 0 & 0 \\
\hline Landfill Inspection & At least bimonthly & 0 & 0 & 0 & 0 & 0 \\
\hline Saltstone Inspection & Weekly & 0 & 0 & 0 & 0 & 0 \\
\hline Interim Sanitary Landfill (postclosure) & Annually & 0 & 0 & 0 & 0 & 0 \\
\hline Air Programs Compliance Inspection & Annually & 0 & 0 & 0 & * & 0 \\
\hline NPDES CSI Inspection & Annually & 0 & 0 & 0 & * & 0 \\
\hline CME Inspection of Groundwater Facilities & Annually & 0 & 0 & 0 & 0 & 0 \\
\hline Small Domestic Water Systems Inspection & Triennially & 0 & NA & NA & 0 & NA \\
\hline
\end{tabular}

*No inspections of these programs conducted in 2007

- 632-G C\&D Landfill, 288-F Ash Landfill, and 488-4D Ash Landfill Inspections - SCDHEC conducted eight routine (at least every other month) inspections - each of which covered the 632-G C\&D, the 288-F Ash, and the 488-4D Ash landfills; the facilities were found to be satisfactory, with no observed deficiencies.

- Z-Area Saltstone Solid Waste Landfill Inspections Saltstone Disposal Facility inspections by SCDHEC continued to be completed weekly. Moisture areas again were observed on the walls of the facility's Vault 4, and were reported to SCDHEC in accordance with the facility's contingency plan. (NOTE: "Moisture areas" are areas on the external walls of the facility's cells that appear damp due to a combination of saltstone shrinkage from curing, bleeding, and process water accumulation at the inner cell walls, and from hydrostatic pressure that causes the water to weep through preexisting construction cracks. For any new cracks, facility personnel conduct an evaluation to determine if repair is necessary. Such moisture areas do not represent freeflowing liquid. Moisture areas on vault walls may indicate the presence of radiological contamination.) Savannah River Remediation (SRS's Liquid Waste Operations contractor) personnel inspected the vault areas in operation daily and communicated the discovery of any new moisture areas to SCDHEC, per the facility contingency plan. SCDHEC performed weekly onsite inspections of Vault 4 to observe existing and potentially new moisture areas. The inspectors detailed the results of their inspections in the Saltstone Disposal Facility Vault 4 Inspection Checklist. SCDHEC has not mandated any addition- al actions other than continuous monitoring of Vault 4 via the aforementioned inspections. No additional actions are pending.

- Interim Sanitary Landfill - SCDHEC personnel conducted an annual post-closure inspection of the Interim Sanitary Landfill September 29. The landfill was found to be satisfactory (the highest possible rating), with no observed deficiencies.

- On-Site Laboratory Evaluation of the D Area Powerhouse Lab - In support of renewing the laboratory certification, an SCDHEC Office of Environmental Laboratory Certification representative conducted an onsite audit of SRS's D Area Powerhouse laboratory December 9. SCDHEC's report of the audit, issued December 30, noted minor deficiencies related to standard operating procedures for laboratory methods. The D Area Powerhouse laboratory is expected to be certified in early 2011.

- $\quad$ Compliance Sampling Inspection (CSI) of NPDES Facilities - A SCDHEC representative inspected NPDES facilities March 1-4. SRS earned the highest ratings possible in all nine categories evaluated.

- Compliance Sampling Inspection (CSI) of D Area NPDES Facilities - SCDHEC representatives inspected NPDES wastewater outfalls at the D Area Powerhouse August 16. No findings or other concerns were noted.

- Compliance Air Inspection - SCDHEC representatives inspected site air emission points March 15-17. The April 19 inspection report stated that "No violations of permit requirements or applicable regulations were observed during this evaluation." 
- Comprehensive Monitoring Evaluation - SCDHEC representatives inspected SRS' groundwater facilities-including monitoring networks at the F Area and H Area Seepage Basins, M Area Settling Basin, Metallurgical Lab Basin, and Sanitary LandfillApril 27. The inspection resulted in no findings.

- Small Domestic Water Systems Inspection SCDHEC representatives inspected SRS's four small domestic water systems February 18.

SCDHEC found all four systems to be operating in compliance with the State Primary Drinking Water Regulations.

\section{Continuous-Release Reporting}

EPCRA (40 CFR 355.40) requires that reportable releases of extremely hazardous substances or CERCLA hazardous substances be reported to any local emergency planning committees and state emergency response commissions likely to be affected by the release. SRS had no EPCRA-reportable releases in 2010.

\section{Unplanned Releases}

Federally permitted releases comply with legally enforceable licenses, permits, regulations, or orders. If an unpermitted release to the environment of a reportable (or greater) quantity of a hazardous substance (including radionuclides) occurs, CERCLA requires notification of the National Response Center. Reportable quantities - not to be confused with threshold values, as defined by EPCRA Section 313 - are those quantities of a hazardous substance greater than or equal to values specified in table 302.4 ("Designation of Hazardous Substances") of 40 CFR 302 ("Designation, Reportable Quantities, and Notification"). SRS had no CERCLAreportable releases in 2010.

The CWA requires that the National Response Center be notified if an oil spill causes a sheen on navigable waters, such as rivers, lakes, or streams. A May 3 oil spill at the 681-3G pump house caused a sheen that triggered a call to the National Response Center. The spill, estimated at less than 5 gallons, was contained to the canal; no oil reached the river. Oil spill reporting has been reinforced with liability provisions in the CERCLA National Contingency Plan.

Two SCDHEC-required notifications were made in response to (1) a March 3 spill of 45 gallons of diesel fuel at SRS's MOX project and (2) a March 7 spill of 200 gallons of diesel fuel at building 717-9N. The site recorded and cleaned up the following spills that did not require reporting under CERCLA or to SCDHEC: 17 chemical, three radioactive wastewater, four sewage, and 73 petroleum product spills.
No unplanned environmental releases (radioactive and nonradioactive) occurred at SRS in 2010 that required sampling and analytical services.

\section{Permits}

SRS had 506 construction and operating permits in 2010 that specified operating levels for each permitted source. Table 3-6 identifies these permits. These numbers, which reflect permits for all primary contractors and tenant organizations at SRS, include some permits

Table 3-6 SRS Construction and Operating Permits, 2010

\begin{tabular}{|c|c|}
\hline Type of Permit & $\begin{array}{l}\text { Number } \\
\text { of Permits }\end{array}$ \\
\hline Air & 9 \\
\hline $\begin{array}{l}\text { U.S. Army Corps of Engineers - } \\
\text { Section 10, Rivers \& Harbors Act } \\
\text { of } 1899\end{array}$ & 1 \\
\hline $\begin{array}{l}\text { U.S. Army Corps of Engineers } \\
\text { Nationwide Permit }\end{array}$ & 5 \\
\hline $\begin{array}{l}\text { U.S. Army Corps of Engineers - } \\
404 \text { Permit (Dredge and Fill) }\end{array}$ & 1 \\
\hline Asbestos Demolition/Abatement & 20 \\
\hline Domestic Water & 221 \\
\hline Industrial Wastewater & 73 \\
\hline NPDES Discharge & 2 \\
\hline NPDES No Discharge & 1 \\
\hline $\begin{array}{l}\text { NPDES General Utility Water } \\
\text { Permit }\end{array}$ & 1 \\
\hline Stormwater Discharge & 1 \\
\hline $\begin{array}{l}\text { Construction Stormwater Grading } \\
\text { Permit }\end{array}$ & 24 \\
\hline RCRA Hazardous Waste & 1 \\
\hline RCRA Solid Waste & 5 \\
\hline RCRA Underground Storage Tank & 7 \\
\hline Sanitary Wastewater & 119 \\
\hline SCDHEC 401 & 1 \\
\hline SCDHEC Navigable Waters & 1 \\
\hline Underground Injection Control & 13 \\
\hline Total & 506 \\
\hline
\end{tabular}


that were voided or closed during 2010. Additional

information on major SRS environmental permits can be found in data table 3-1 (see "Environmental Data/Maps -2010 "section of CD accompanying this report).

Editor's note: The "Environmental Compliance" chapter is unique in that its number of contributing authors is far greater than the number for any other chapter in this report. Space/layout constraints prevent us from listing all of them and their organizations on the chapter's first page, so we list them here instead. Their contributions, along with those of the report's other authors, continue to play a critical role in helping us produce a quality document-and are very much appreciated.

\author{
Savannah River Nuclear Solutions \\ Charles Bishop, RI\&ES \\ Tracy Bryant, RI\&ES \\ Vivian Cato, RI\&ES \\ Lori Coward, RI\&ES \\ Keith Dyer, RI\&ES \\ Greta Fanning, RI\&ES \\ Jim Fudge, RI\&ES \\ Sonny Goldston, RI\&ES \\ Mike Griffith, RI\&ES \\ John Harley, WME \\ Ginger Humphries, RI\&ES \\ Jeff Lintern, RI\&ES \\ Nancy Lowry, RI\&ES \\ Bill Maloney, RI\&ES \\ Al Mamatey, RI\&ES \\ Lynn Martin, RI\&ES \\ Shelia McFalls, RI\&ES \\ Ted Millings, RI\&ES \\ Hal Morris, RI\&ES \\ Vernon Osteen, RI\&ES \\ Bill Payne, RI\&ES \\ Mike Roper, RI\&ES \\ Eloy Saldivar, RI\&ES \\ Carl Shealy, RI\&ES
}

\author{
Cary Stevens, RI\&ES \\ Ben Terry, RI\&ES \\ Art Timms, RI\&ES \\ Kim Wolfe, RI\&ES \\ Stephanie Yazzie, RI\&ES
}

\section{Savannah River Remediation \\ Ron Campbell \\ Keith Liner \\ Owen Stevens}

\section{Shaw-Areva MOX Services}

Carl Mazzola

Parsons

Richard Gurske

\section{Savannah River Ecology Laboratory}

Donald Mosser

\section{Wackenhut Services}

Julie Wilson

Ameresco

Ken Chacey 


\section{Effluent Monitoring}

Greta Fanning, Donald Padgett, and Monte Steedley

Regulatory Integration \& Environmental Services

Timothy Jannik

Savannah River National Laboratory

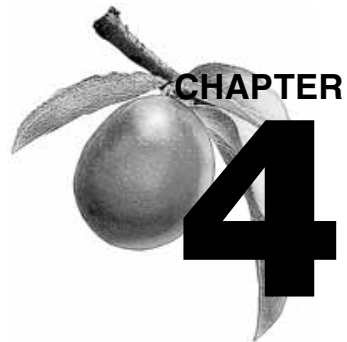

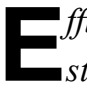
ffluent monitoring at the Savannah River Site (SRS) is conducted to demonstrate compliance with applicable standards and regulations. Site effluent monitoring activities are divided into radiological and nonradiological programs. The monitoring is conducted by the Environmental Monitoring Services group of the site's Regulatory Integration \& Environmental Services organization-following specific sampling and analytical procedures. A summary of data results is presented in this chapter; more complete data can be found in tables on the CD housed inside the back cover of this report.

\section{Radiological Monitoring}

The U.S. Environmental Protection Agency's National Emission Standards for Hazardous Air Pollutants (NESHAP) establish the requirements and limits that regulate radionuclide emissions from facilities owned or operated by the U.S. Department of Energy (DOE). The methods for estimating and reporting radioactive emissions are detailed in these regulations. The South Carolina Department of Health and Environmental Control (SCDHEC) regulates both radioactive and nonradioactive air pollutant emissions from SRS sources. Each source of air emissions is permitted or exempted by SCDHEC on the SRS Part 70 Air Quality Permits (issued in 2003 and 2007), with specific limitations and monitoring requirements identified. This section of the chapter will cover the radioactive emissions.

Radiological effluent monitoring results are a major component in determining compliance with applicable dose standards. SRS works to ensure that radiation exposures to employees and releases of radioactivity to the environment are maintained below regulatory limits, and deliberate efforts are taken to further reduce exposures and releases.

SRS airborne and liquid effluents that potentially contain radionuclides are monitored at their points of discharge by a combination of direct measurement and/or sample extraction and analysis. Each operating facility maintains ownership of, and is responsible for, its radiological effluents.

Brief summaries of analytical results are presented in this chapter; complete data sets, as well as maps showing applicable sampling locations, can be found in tables on the CD housed inside the back cover of this report. Tables on the CD (see "Environmental Data/ Maps - 2010") are referred to in this chapter as "data table 4-X." Tables in the chapter itself are referred to simply as "table $4-\mathrm{X}$."

Data tables 4-1 through 4-4 provide analytical results for radioactive air and liquid effluent measurements taken at SRS in 2010.

Unspecified alpha and beta radiation releases (the measured gross activity minus the identified individual radionuclides) in airborne and liquid releases are large contributors - on a percentage basis - to offsite doses, especially for the airborne pathway from diffuse and fugitive releases (see definitions below).

The unspecified alpha and beta radiation releases are listed separately in data tables 4-3 and 4-4. They conservatively include naturally occurring radionuclides - such as uranium, thorium, and potassium-40 - and small amounts of unidentified manmade radionuclides. For dose calculations, the unspecified alpha releases were assigned the plutonium-239 dose factor, and the unspecified beta releases were assigned the strontium-90 dose factor (chapter 6, "Potential Radiation Doses").

\section{Airborne Emissions}

Process area stacks that release, or have the potential to release, radioactive materials are monitored continuously by online monitoring and/or sampling systems. 


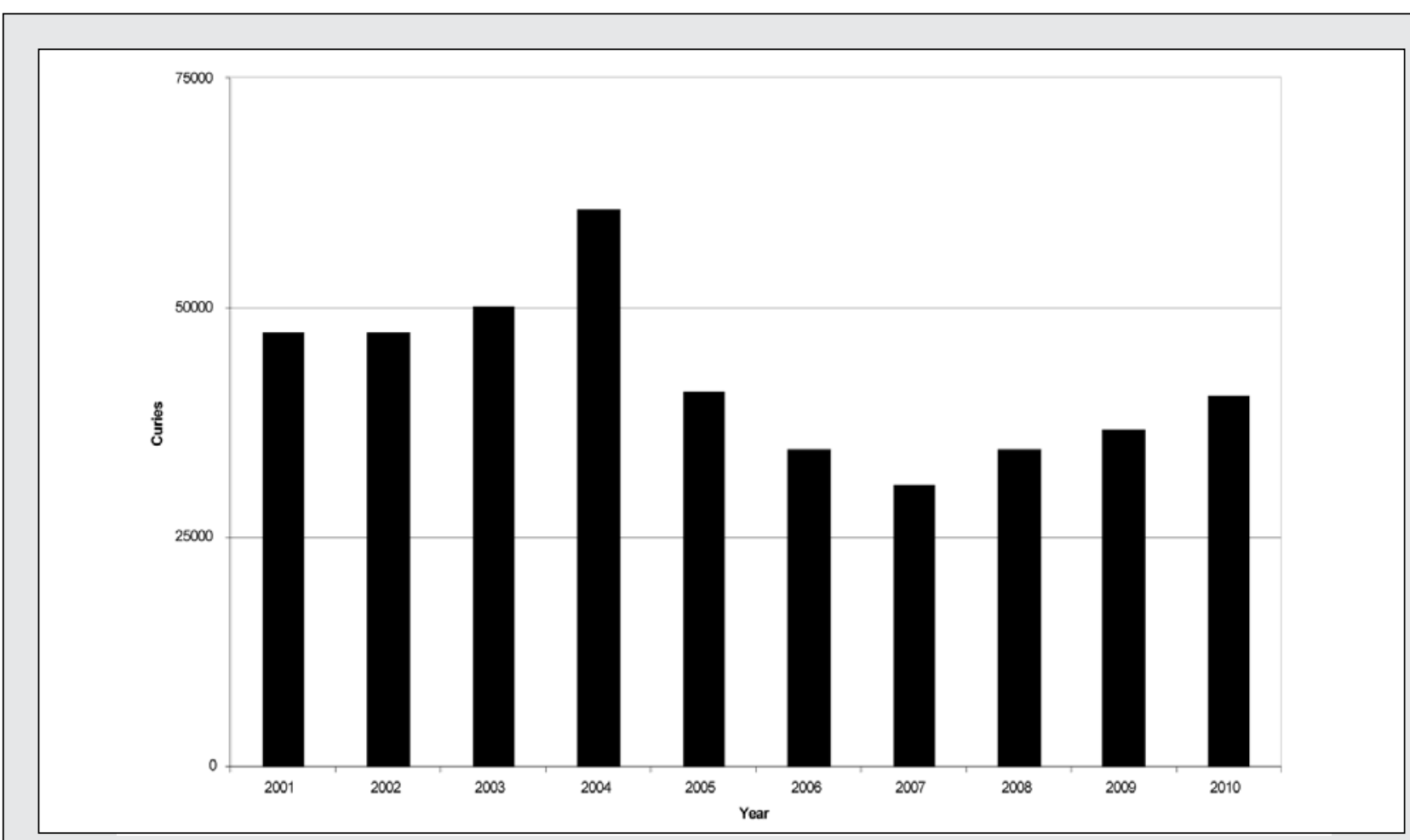

Figure 4-1 Ten-Year History of SRS Annual Atmospheric Tritium Releases

Depending on the processes involved, discharge stacks also may be monitored with real-time instrumentation to determine instantaneous and cumulative atmospheric releases to the environment. Tritium is one of the radionuclides monitored with continuous real-time instrumentation.

Sampling was discontinued at P Area and R Area Reactors during June 2010 because of the demolition of the main stacks and the removal of monitoring equipment. These areas have been removed permanently from service.

\section{Diffuse and Fugitive Sources}

Estimates of radionuclide releases from unmonitored diffuse and fugitive sources are calculated on an annual basis and are included in the SRS radioactive release totals. A diffuse source is defined as an area source, such as a pond or disposal area. A fugitive source is defined as an undesignated localized source, such as an open tank or naturally ventilated building.

Diffuse and fugitive releases are calculated using EPA's recommended methods [EPA, 2002a]. Because these methods employ conservative assumptions, they generally lead to overestimates of actual emissions. Though these releases are not monitored at their source, onsite and offsite environmental monitoring stations are in place to quantify unexpectedly large diffuse and fugitive releases (chapter 5, "Environmental Surveillance").

\section{Monitoring Results Summary}

The total amount of radioactive material released to the environment is quantified by using (1) data obtained from continuously monitored airborne effluent release points and (2) estimates of diffuse and fugitive sources.

Tritium Tritium in elemental and oxide forms accounted for more than 99 percent of the total radioactivity released to the atmosphere - and more than 90 percent of the estimated NESHAP compliance dose-from SRS operations in 2010. Approximately 40,500 $\mathrm{Ci}$ of tritium were released from the site in 2010-compared with about 36,900 $\mathrm{Ci}$ in 2009. Approximately 66 percent of the releases came from the site's tritium facilities, and about 32 percent were estimated diffuse releases from the Mixed Waste Management Facility Phytoremediation Unit and the P-Reactor Disassembly Basin Decommissioning Project (evaporation of Disassembly Basin water).

The amount of tritium released from SRS fluctuates because of changes in the site's missions and in the annual Tritium Facility production schedules. For the past 10 years, the amount has ranged from about 30,000 to $60,000 \mathrm{Ci}$ per year (figure 4-1). 
Comparison of Average Concentrations in Airborne Emissions to DOE Derived Concentration Guides Average concentrations of radionuclides in airborne emissions are calculated by dividing the amount of each radionuclide released annually from each stack by the respective yearly stack-flow volumes. These average concentrations then can be compared to the DOE derived concentration guides (DCGs) in DOE Order 5400.5, "Radiation Protection of the Public and the Environment," as a screening method to determine if existing effluent treatment systems are proper and effective. Data table 4-5 provides the 2010 atmospheric effluent annualaverage concentrations, their comparisons against the DOE DCGs, and the quantities of radionuclides released are provided by discharge point.

DCGs are used as reference concentrations for conducting environmental protection programs at all DOE sites. DCGs are applicable at the point of discharge (prior to dilution or dispersion) under conditions of continuous exposure.

Most of the SRS radiological stacks/facilities release small quantities of radionuclides at concentrations below the DOE DCGs. However, because of the nature of the operations, tritium DCGs are exceeded routinely at K Area and L Area. Plutonium-239 exceeded the DCG at the F Area Main Stack during 2010 for the first time since 2006. This exceedance is due to transuranic waste repacking activities. The offsite dose from all atmospheric releases, however, remained well below the DOE and EPA annual atmospheric pathway dose standard of 10 mrem $(0.1$ $\mathrm{mSv}$ ), as discussed in chapter 6 .

\section{Liquid Discharges}

Each process area liquid effluent discharge point that releases, or has potential to release, radioactive materials is sampled routinely and analyzed for radioactivity.

Depending on the processes involved, liquid effluents also may be monitored with real-time instrumentation to ensure that releases are managed within established limits. Because the instruments have limited detection sensitivity, online monitoring systems are not used to quantify SRS liquid radioactive releases at their current low levels. Instead, samples are collected for more sensitive laboratory analysis.

\section{Monitoring Results Summary}

Data from continuously monitored liquid effluent discharge points are used in conjunction with site seepage basin and Solid Waste Disposal Facility (SWDF) migration release estimates to quantify the total radioactive material released to the Savannah River from SRS operations. Data table 4-4 provides SRS liquid radioactive releases for 2010. These data are a major component in the determination of offsite dose consequences from SRS operations.

Direct Discharges of Liquid Effluent Direct discharges of liquid effluents are quantified at the point of release to the receiving stream, prior to dilution by the stream. The release totals are based on measured concentrations and flow rates.

Tritium accounts for nearly all the radioactivity discharged in SRS liquid effluents. The total amount of tritium released directly from process areas-i.e., reactor, separations, Effluent Treatment Project (ETP) to site streams during 2010 was $227 \mathrm{Ci}$. Direct releases of tritium to site streams for the years 2001-2010 are shown in figure 4-2.

D Area and TNX operations were discontinued in 2000 and 2001, respectively. A Area releases represent only a small percentage of the total direct releases of tritium to site streams. The reactor area releases include overflows from PAR Pond and L Lake.

Groundwater migration and transport of radionuclides from site seepage basins and the SWDF are discussed in chapter 5 .

\section{Comparison of Average Concentrations in Liquid Releases to DOE Derived Concentration Guides In addition to dose standards, DOE Order 5400.5 imposes other control considerations on liquid releases. These considerations are applicable to direct discharges but not to seepage basin and groundwater discharges. The DOE order lists DCG values for most radionuclides.}

DCGs are applicable at the point of discharge from the effluent conduit to the environment (prior to dilution or dispersion). According to DOE Order 5400.5 , exceedance of the DCGs at any discharge point may require an investigation of "best available technology" (BAT) waste treatment for the liquid effluents. Tritium in liquid effluents is specifically excluded from BAT requirements; however, it is not excluded from other ALARA considerations. DOE DCG compliance is demonstrated when the sum of the fractional DCG values for all radionuclides detectable in the effluent is less than 1.00, based on consecutive 12-month-average concentrations. Data 


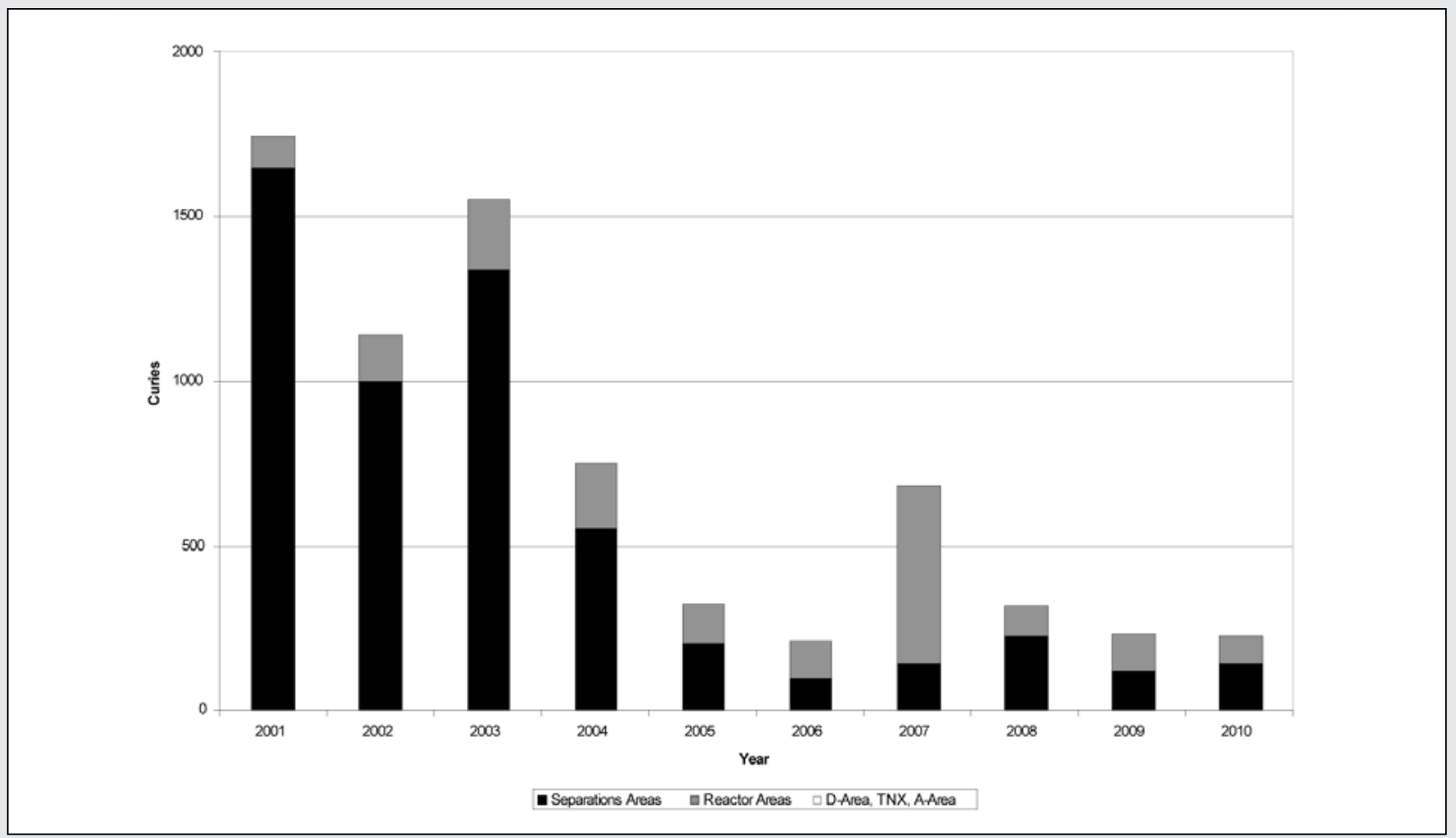

Figure 4-2 Ten-Year History of Direct Releases of Tritium to SRS Streams

table $4-6$ provides the 2010 liquid effluent annualaverage concentrations, their comparisons against the DOE DCGs, and the quantities of radionuclides released are provided by discharge point. No liquid discharge points exceeded the DOE DCGs during 2010 .

\section{Nonradiological Monitoring Airborne Emissions}

SCDHEC regulates both radioactive and nonradioactive criteria and toxic air pollutant emissions from SRS sources. Each source of air emissions is permitted or exempted by SCDHEC on the SRS Part 70 Air Quality Permits, with specific limitations and monitoring requirements identified. This section will cover only nonradioactive emissions.

The bases for the limitations and monitoring requirements specified in the Part 70 Air Quality Permits are outlined in various South Carolina and federal air pollution control regulations and standards. Many of the applicable standards are source dependent, i.e., applicable to certain types of industries, processes, or equipment. However, some standards govern all sources for criteria pollutants, toxic air pollutants, and ambient air quality. Air pollution control regulations and standards applicable to SRS sources are discussed briefly in appendix A, "Applicable Guidelines, Standards, and Regulations," of this report. The SCDHEC air standards for toxic air pollutants can be found at http://www. scdhec.gov/environment/baq/docs/regs/.

\section{Description of Monitoring Program}

Major nonradiological emissions of concern from SRS facility stacks include sulfur dioxide, carbon monoxide, oxides of nitrogen, particulate matter smaller than 10 micrometers and smaller than 2.5 micrometers, volatile organic compounds (VOCs), and toxic air pollutants. With issuance of the Part 70 Air Quality Permits, SRS has several continuous and periodic monitoring requirements; only the most significant are discussed below.

The primary method of source monitoring at SRS is the annual air emissions inventory. Actual emissions from SRS sources are determined during this inventory from standard calculations using source operating parameters, such as hours of operation, process throughput, and emission factors provided in the EPA "Compilation of Air Pollution Emission Factors," AP-42. Many of the SRS processes, however, are unique sources requiring nonstandard, complex calculations. The hourly and total actual annual emissions for each source then can be compared against their respective permit limitations. 
At the SRS A Area biomass boiler and D Area

Powerhouse facility, airborne emission specialists under contract to the site perform stack compliance tests every two years. The tests include sampling of boiler exhaust gases to determine particulate matter. In addition, opacity emissions are monitored weekly by visual inspection.

For the steam-generating fuel oil-fired boiler in A Area and fuel oil-fired water heaters in B Area-and for diesel-powered equipment - compliance with sulfur dioxide standards is determined by analysis of fuel oil purchased from offsite vendors. Sulfur content of the fuel oil must be below 0.05 percent_-and must be certified by the fuel supply vendor and reported to SCDHEC semiannually.

The monitoring of SRS diesel-powered equipment includes tracking fuel oil consumption monthly and calculating a 12-month rolling total for determining permit compliance with a site consumption limit.

SRS has several soil vapor extraction units and two air strippers that are sources of toxic air pollutants and VOCs. These units must be sampled monthly for VOC concentrations, and the total VOC emissions must be calculated for comparison against a 12-month rolling limit. The VOC emissions are reported to SCDHEC on a quarterly basis.

Several SRS sources have pollutant control devicessuch as, electrostatic precipitators, baghouse dust collectors, or condensers - whose parameters must be monitored continuously or whenever the system is operated. The operating parameters must be recorded and compared against specific operating ranges.

Compliance by all SRS permitted sources is evaluated during annual compliance inspections by the local SCDHEC district air manager. The inspections include a review of each permit condition; i.e., daily monitoring readings, equipment calibrations, control device inspections, etc. SCDHEC performed an air compliance inspection on March 17, 2010 and found no instances of noncompliance.

\section{Monitoring Results Summary}

SRS is required to report its emissions inventory for all site air emission sources annually. Operating data are compiled and emissions calculated for each calendar year. Data table 4-7 provides a list of the 2006-2010 estimated emissions.

The total SCDHEC air emission estimates for all SRS permitted sources, as determined by the air emissions inventory conducted in each of the past five years, are provided in table 4-1. A review of the calculated emissions for each source for each calendar year determined that SRS sources had operated in compliance with permitted emission rates. Some toxic air pollutants (e.g., benzene) regulated by SCDHEC also are, by nature, VOCs. As such, the total for VOCs in table 4-1 includes toxic air pollutant emissions.

Four pulverized coal-fired boilers are maintained by SRS at the D Area Powerhouse facility. Each of the boilers

Table 4-1 SRS Estimated SCDHEC Standard 2 Pollutant Air Emissions, 2006-2010

\begin{tabular}{|c|c|c|c|c|c|}
\hline \multirow[t]{2}{*}{ Pollutant Name } & \multicolumn{5}{|c|}{ Emissions (Tons/Year) } \\
\hline & 2006 & 2007 & 2008 & 2009 & 2010 \\
\hline Sulfur dioxide $\left(\mathrm{SO}_{\mathrm{x}}\right)$ & $5.10 \mathrm{E}+03$ & $4.25 \mathrm{E}+03$ & $4.07 E+03$ & $4.00 \mathrm{E}+03$ & $4.11 \mathrm{E}+03$ \\
\hline Total particulate matter (PM) & $5.04 \mathrm{E}+02$ & 4.17E+02 & $4.59 \mathrm{E}+02$ & $3.99 \mathrm{E}+02$ & $8.03 E+02$ \\
\hline Particulate matter $<10$ micrometers $\left(\mathrm{PM}_{10}\right)$ & $3.82 \mathrm{E}+02$ & $2.45 \mathrm{E}+02$ & $3.13 E+02$ & $2.64 \mathrm{E}+02$ & $6.37 \mathrm{E}+02$ \\
\hline Particulate matter $<2.5$ micrometers $\left(\mathrm{PM}_{2.5}\right)$ & $3.19 \mathrm{E}+02$ & $2.20 \mathrm{E}+02$ & $2.65 E+02$ & $2.22 \mathrm{E}+02$ & $1.36 \mathrm{E}+02$ \\
\hline Carbon monoxide (CO) & $7.83 \mathrm{E}+01$ & $7.62 \mathrm{E}+01$ & $6.73 E+02$ & 4.07E+01 & $4.46 \mathrm{E}+01$ \\
\hline $\begin{array}{l}\text { Volatile organic compounds (VOCs)(Ozone } \\
\text { Precursors) }\end{array}$ & $1.69 \mathrm{E}+01$ & $1.61 \mathrm{E}+01$ & $6.53 E+01$ & $4.88 \mathrm{E}+00$ & $4.88 \mathrm{E}+00$ \\
\hline Gaseous fluorides (as hydrogen fluoride) & $1.42 \mathrm{E}+01$ & $1.27 \mathrm{E}+01$ & $1.22 \mathrm{E}+01$ & $1.22 \mathrm{E}+01$ & $1.22 \mathrm{E}+01$ \\
\hline Nitrogen dioxide $\left(\mathrm{NO}_{\mathrm{x}}\right)$ & $3.15 \mathrm{E}+03$ & $2.63 \mathrm{E}+03$ & $1.89 \mathrm{E}+03$ & $1.79 \mathrm{E}+03$ & $2.06 \mathrm{E}+03$ \\
\hline Lead (lead components) & $7.60 \mathrm{E}-02$ & $1.91 \mathrm{E}-02$ & 2.67E-02 & $3.40 \mathrm{E}-02$ & 3.91E-02 \\
\hline
\end{tabular}


Table 4-2 2010 Boiler Stack Test Results ${ }^{a}$

\begin{tabular}{|c|c|c|c|}
\hline \multirow[b]{2}{*}{ Boiler } & \multicolumn{3}{|c|}{ Emission Rates } \\
\hline & Pollutant & $\mathrm{Lb} / 10^{6} \mathrm{Btu}$ & Lb/hr \\
\hline D Area Boiler \#1 & $\begin{array}{l}\text { Particulate matter } \\
\text { Sulfur dioxide }{ }^{b} \\
\text { Opacity }{ }^{c}\end{array}$ & $\begin{array}{l}0.2598 \\
1.52 \\
\text { Avg. 13.7\% }\end{array}$ & $\begin{array}{l}113.28 \\
413.83\end{array}$ \\
\hline D Area Boiler \#2 & $\begin{array}{l}\text { Particulate matter } \\
\text { Sulfur dioxide } \\
\text { Opacity }^{\mathrm{b}}\end{array}$ & $\begin{array}{l}0.258 \\
1.17 \\
\text { Avg. 13.2\% }\end{array}$ & $\begin{array}{r}86.89 \\
336.13\end{array}$ \\
\hline \multicolumn{4}{|c|}{$\begin{array}{l}\text { D Area Boiler } \# 3^{d} \\
\text { (Did not operate during 2010) }\end{array}$} \\
\hline D Area Boiler \#4 & $\begin{array}{l}\text { Particulate matter } \\
\text { Sulfur dioxide }^{b} \\
\text { Opacity }^{c}\end{array}$ & $\begin{array}{l}0.189 \\
1.54 \\
\text { Avg. } 6.3 \%\end{array}$ & $\begin{array}{r}95.11 \\
482.00\end{array}$ \\
\hline
\end{tabular}

a Boiler \#1 source test October 22, 2010; Boiler \#2 source test February 3, 2010;

Boiler \#4 source test December 9, 2010

${ }^{\mathrm{b}}$ SCDHEC's Title V permitted emission limits are $0.6 \mathrm{lb} / \mathrm{million}$ BTU for particulates and

$3.5 \mathrm{lb} /$ million BTU for sulfur dioxide.

c Opacity limit $40 \%$

${ }^{\mathrm{d}}$ Not stack tested during 2010

has a steam generation rating of 330,000 lbs per hour (396.0E $+06 \mathrm{Btu} / \mathrm{hr}$ capacity).

SRS began operation of a biomass boiler and an oilfired backup boiler in 2008, replacing the old A Area coal fired boilers. Known as the 784-7A Steam Facility, these two boilers are substantially smaller and burn cleaner than the two coal-fired boilers they replaced. The biomass boiler and oil-fired backup boiler each produce significantly less particulate matter, sulfur dioxide, and nitrogen dioxide emissions than the two coal-fired boilers.

The D Area Powerhouse has four coal-fired boilerseach on a biennial stack test schedule required by the $\mathrm{D}$ Area Part 70 Air Quality Permit. D Area Powerhouse boilers D\#1, D\#2, and D\#4 were source tested in 2010; the test results are shown in table 4-2. The particulate matter, sulfur dioxide, and visible emissions of these boilers were found to be in compliance with their permitted limits.

The three H Area Powerhouse boilers have not operated since 2000-2001.

SRS also operates one package steam-generating boiler in K Area, fired by No. 2 fuel oil. The percent of sulfur in the fuel oil must be vendor certified semiannually to ensure that the fuel meets permit specifications; the certification was documented twice during 2010. Biomass boilers in K Area and L Area began operations in December 2010; initial monitoring data from these units will be incorporated into the SRS Environmental Report for 2011.

The total diesel fuel consumption for portable air compressors, generators, emergency cooling water pumps, and fire water pumps was found to be well below the SRS limit for the entire reporting period. As reported to SCDHEC during 2010, the calculated annual VOC emissions were well below the permit limit for each unit.

\section{Ambient Air Quality}

Under existing regulations, SRS is not required to conduct onsite monitoring for ambient air quality; however, the site is required to show compliance with various air quality standards. To accomplish this, air dispersion modeling is conducted as required as part of the Title $\mathrm{V}$ and construction permitting process. Additional information about ambient-air-quality regulations at the site can be found in appendix A of this report. 


\section{Liquid Discharges}

\section{Description of Monitoring Program}

SRS monitors nonradioactive liquid discharges to surface waters through the National Pollutant Discharge Elimination System (NPDES), as mandated by the Clean Water Act. As required by EPA and SCDHEC, SRS has NPDES permits in place for discharges to the waters of the United States and South Carolina. These permits establish the specific sites to be monitored, parameters to be tested, and monitoring frequency-as well as analytical, reporting, and collection methods. Detailed requirements for each permitted discharge point can be found in the individual permits, which are available to the public through SCDHEC's Freedom of Information office at 803-898-3882.

In 2010, SRS discharged water into site streams under three NPDES permits: two for industrial wastewater, SC0047431 (covers D Area) and SC0000175 (covers remainder of site), and one for stormwater runoff, SCR000000 (industrial discharge). A fourth permit, SCR100000, does not require sampling unless requested by SCDHEC to address specific discharge issues at a given construction site; SCDHEC did not request such sampling in 2010.SRS submitted a permit application in 2006 for each of nine individual stormwater outfalls for which the average of any four consecutive analyses exceeded the proposed EPA Multisector General Permit benchmarks. These outfalls are expected to be covered under the upcoming new Industrial Stormwater General Permit rather than the individual permits.

Permit ND0072125 is a "no discharge" permit regulating the land application of biosolids (dried sludge) from onsite sanitary wastewater treatment facilities. One application (approximately 76 cubic yards) of air-dried sludge was performed in June 2010. All sample results were within permit limits for metals and nutrients. SRS had applied to SCDHEC (in August 2009) for a 10-year renewal of the permit; SCDHEC subsequently issued the renewal for an additional 10 years, effective December $1,2010$.

NPDES samples are collected in the field according to 40 CFR 136 ("Guidelines Establishing Test Procedures for the Analysis of Pollutants"), the federal document that lists specific sample collection, preservation, and analytical methods acceptable for the type of pollutant to be analyzed. Chain-of-custody procedures are followed after collection and during transport to the analytical laboratory. The samples then are accepted by the laboratory and analyzed according to procedures listed in 40 CFR 136 for the parameters required by the permit.

\section{Monitoring Results Summary}

SRS reports industrial wastewater analytical results to SCDHEC through a monthly discharge monitoring report (EPA Form 3320-1). Results of 5,059 sample analyses performed during 2010 indicated that no NPDES permit exceptions occurred. Data table 4-8 provides a compilation of industrial waterwater analytical data for 2010 .

Sixteen stormwater outfalls were scheduled for compliance sampling in 2010. Due to various factorsincluding a 2-month delay in the issuance of a sampling plan, fewer rain events during normal business hours, and associated drought-like conditions - only 13 of the stormwater outfalls could be sampled. Data table 4-9 provides a compilation of stormwater analytical data for 2010. 



\title{
Environmental Surveillance
}

\author{
Teresa Eddy, Donald Padgett, and Monte Steedley \\ Regulatory Integration \& Environmental Services \\ Timothy Jannik \\ Savannah River National Laboratory
}

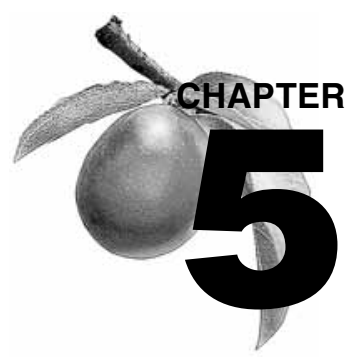

E nvironmental surveillance at the Savannah River Site (SRS) is designed to survey and quantify any effects that routine and nonroutine operations could have on the site and on the surrounding area and population. Site surveillance activities are divided into radiological and nonradiological programs.

As part of SRS's radiological surveillance program, routine surveillance of all applicable radiation exposure pathways is performed on all environmental media (air, rain, surface water, soil, sediment, vegetation, drinking water, food products, wildlife, and aquatic wildlife) that could lead to a measurable annual dose above background at and beyond the site boundary. Radionuclides present in and around the SRS environment may be from a number of sources, including (1) natural background, (2) fallout from historical atmospheric testing of nuclear weapons, (3) nuclear power plant operations, and (4) routine SRS operations.

Nonradioactive environmental surveillance at SRS involves the sampling and analysis of surface water, drinking water, air, sediment, groundwater, and fish. Results from the analyses of surface water, drinking water, sediment, and fish are discussed in this chapter. A description of the groundwater monitoring program and analysis results can be found in chapter 7 ,

"Groundwater."

The Savannah River is monitored by SRS and other groups, including the South Carolina Department of Health and Environmental Control (SCDHEC), the Georgia Department of Natural Resources, Georgia Power Company's Vogtle Electric Generating Plant (VEGP, operating in Georgia), and the City of Savannah, Georgia.

Brief summaries of analytical results are presented in this chapter; complete data sets can be found in tables on the CD (see "Environmental Data/Maps - 2010") housed inside the back cover of this report. Also contained on the $\mathrm{CD}$ are maps showing all applicable sampling locations. Tables on the $\mathrm{CD}$ are referred to in this chapter as "data table 5-X." Tables in the chapter itself are referred to simply as "table $5-\mathrm{X} . "$

References to detectable amounts or levels of radioactivity within this chapter are synonymous with activity that is greater than the minimum detectable concentration (MDC) for a particular analytical method. The MDC is the smallest amount or concentration that can be distinguished in a sample by a given measurement system at a preselected counting time and at a given confidence level. Representative MDC values for radiological analyses can be found in table 2 ("Representative Minimum Detectable Concentrations for Radiological Analyses") in the "Sampling" section of the CD.

\section{Radiological Surveillance}

\section{Air \\ Description of Surveillance Program}

SRS conducts atmospheric air monitoring both on and off site to determine whether airborne radionuclides have reached the environment in measurable quantities from routine and nonroutine SRS releases, and to verify and modify the models that are used to show compliance with the $10-\mathrm{mrem} /$ year dose limit specified in DOE Order 5400.1, "Radiation Protection of the Public and the Environment." The atmospheric surveillance program is divided into two primary areas: air and rainwater.

The Environmental Monitoring group maintains a network of 15 atmospheric (ambient) surveillance sampling stations in and around SRS to monitor the concentration of tritium and radioactive particulate matter in the air. The surveillance stations are placed at the center of the site; around the site perimeter; at a regional reference location (assumed to be unimpacted by site operations) approximately 25 miles from the site; 


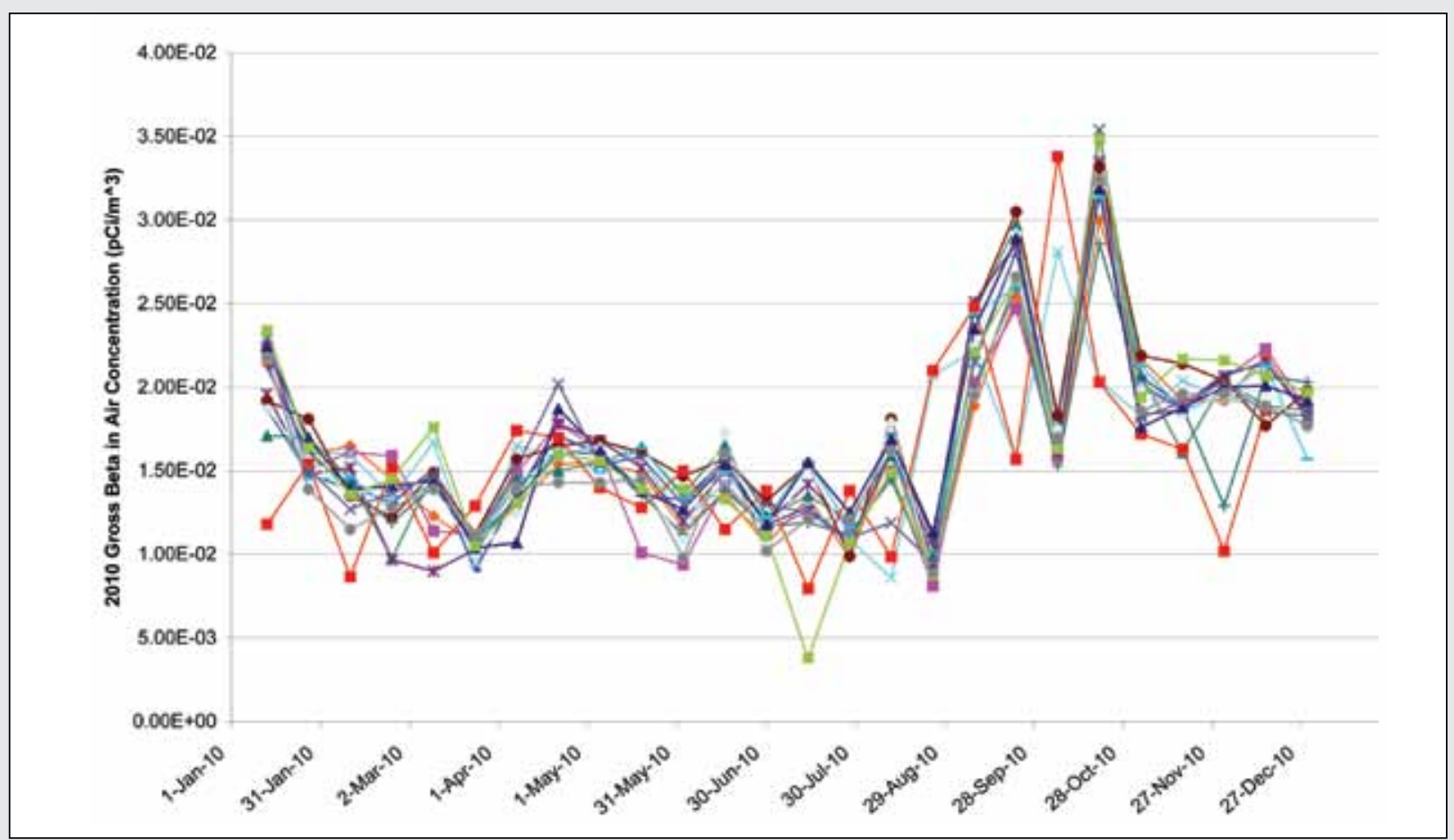

Figure 5-1 Gross Beta-In-Air Concentrations Measured in Glass Fiber Filters for 15 Locations, 2010

and in population centers 25 and 100 miles from the site. Placement on the site boundary was designed to ensure that at least one monitoring station is located in every 45 -degree sector.

Each air surveillance sampling station consists of the following:

- Glass fiber filter paper for sampling airborne particulates to quantify gamma-emitting radionuclides, gross alpha/beta-emitting radionuclides, total strontium, and the actinides (the elements plutonium, americium, uranium, curium, neptunium, and thorium), sampled/analyzed biweekly

- Charcoal canister for sampling radioiodine and other gamma-emitting radionuclides to complement the glass fiber filter results, sampled biweekly/analyzed annually

- Silica gel for sampling tritiated water vapor, sampled/analyzed biweekly

- Rainwater collection to quantify tritium in rainwater, sampled/analyzed monthly

- Rain ion resin column for sampling rainwater to quantify gamma-emitting radionuclides, gross alpha/beta-emitting radionuclides, total strontium, and the actinides, sampled/analyzed monthly

\section{Surveillance Results Summary}

Except for tritium, no specific radionuclides were routinely detectable - greater than the minimum detectable concentration (MDC) of the analysis method-at the site perimeter in 2010.

Both onsite and offsite radionuclide concentrations were similar to levels observed in previous years (see expanded discussion in paragraphs that follow). Tritium, released as part of routine SRS operations, becomes part of the natural environment. Monitoring ensures that information will be available to determine whether any potential health risk to the surrounding population is created.

\section{Glass Fiber Filter Airborne Particulates Results} (data table 5-1) Average gross alpha and gross beta results from 2010 generally were higher than those of 2009 (tables 5-1, 5-2). Gross alpha results were consistent with historical results in demonstrating long-term variability. Gross beta results showed elevated levels at every air surveillance station location around September 2010 (figure 5-1). Tests confirmed that the elevated levels were statistically different than the historical levels. With the exception of these data, gross beta results were consistent with historical results in demonstrating long-term variability. 
Two out of 363 filter samples for 2010 contained detectable amounts of the manmade gamma-emitting radionuclide cesium-137, which is consistent with the historical results, in which only a small number of air samples have contained detectable cesium-137 activity. As part of SRS routine operations, cesium-137 is released into the atmosphere at quantities well below the derived concentration guide.

During 2010, detectable levels of uranium-234 were observed in nine of 15 air samples, and detectable levels of uranium-238 were observed in 10 of 15 air samples; however, no detectable levels of uranium-235 were observed in any of the 2010 samples. These results are similar to those observed in 2009 and previous years. Uranium is naturally occurring in soil, and therefore expected to be present in low concentrations on some particulate filters. By weight, natural uranium is 99percent uranium-238, 0.72-percent uranium-235, and 0.0055 -percent uranium-234. However, by radioactivity, natural uranium is 48.9-percent uranium-234, 48.9percent uranium-238, and 2.2-percent uranium235 . Because the analytical method quantifies the radioactivity, uranium-234 and -238 are sometimes

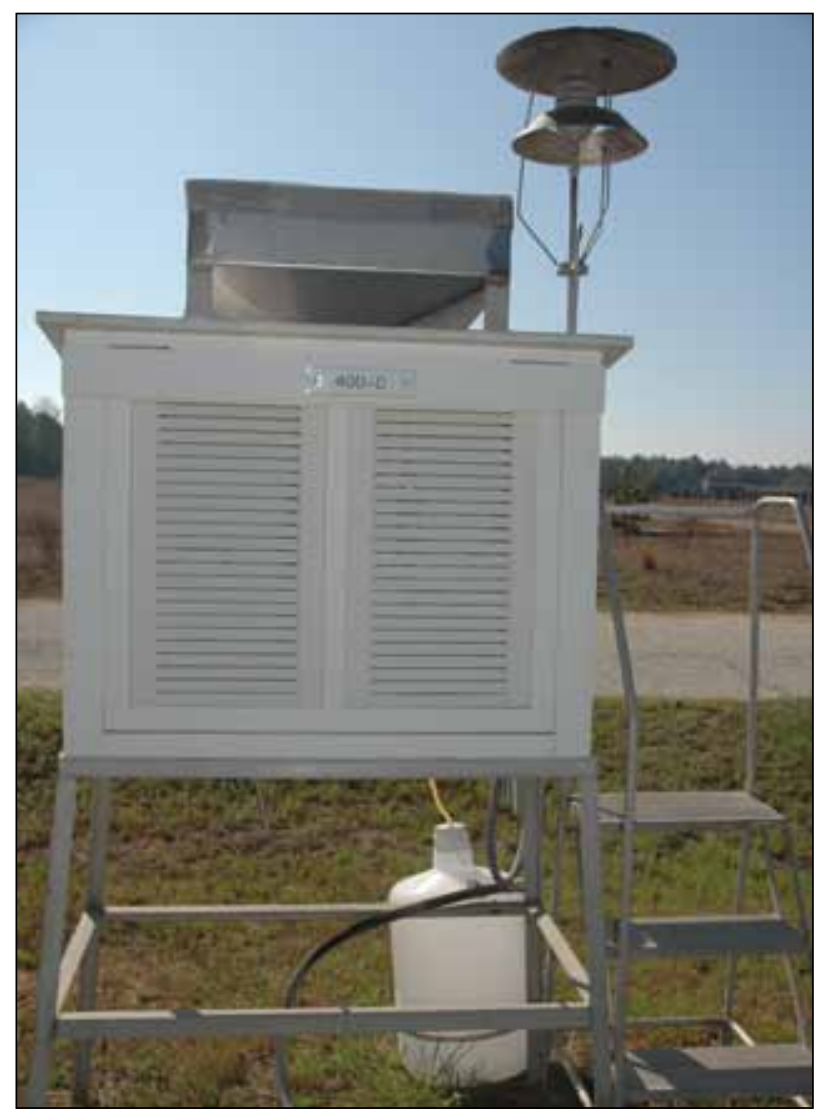

detected when uranium-235 is not. Aside from uranium, the only alpha-emitting radionuclide observed was americium-241 - in four of 15 air samples. Generally, these concentrations were consistent with historical results. All other alpha-emitting isotopes were below detection levels.

Charcoal Canister Results (data table 5-2) No gamma-emitting radionuclides, including radioiodine, were detected in the annual 2010 charcoal canister results; this is consistent with the historical trends.

\section{Silica Gel Tritium-In-Air Results (data table}

5-3) Tritium is released as part of routine SRS operations, and becomes part of the natural environment. Monitoring ensures that it poses no health risk to the surrounding population. Tritium-inair results for 2010 were similar to those observed in 2009 , and were consistent with the long-term variability of historical results. Tritium-in-air results showed detectable levels in 108 ( 28 percent) of the 389 silica gel samples for 2010. As in previous years, the Burial Ground North (BGN) location showed average and maximum concentrations significantly higher than those

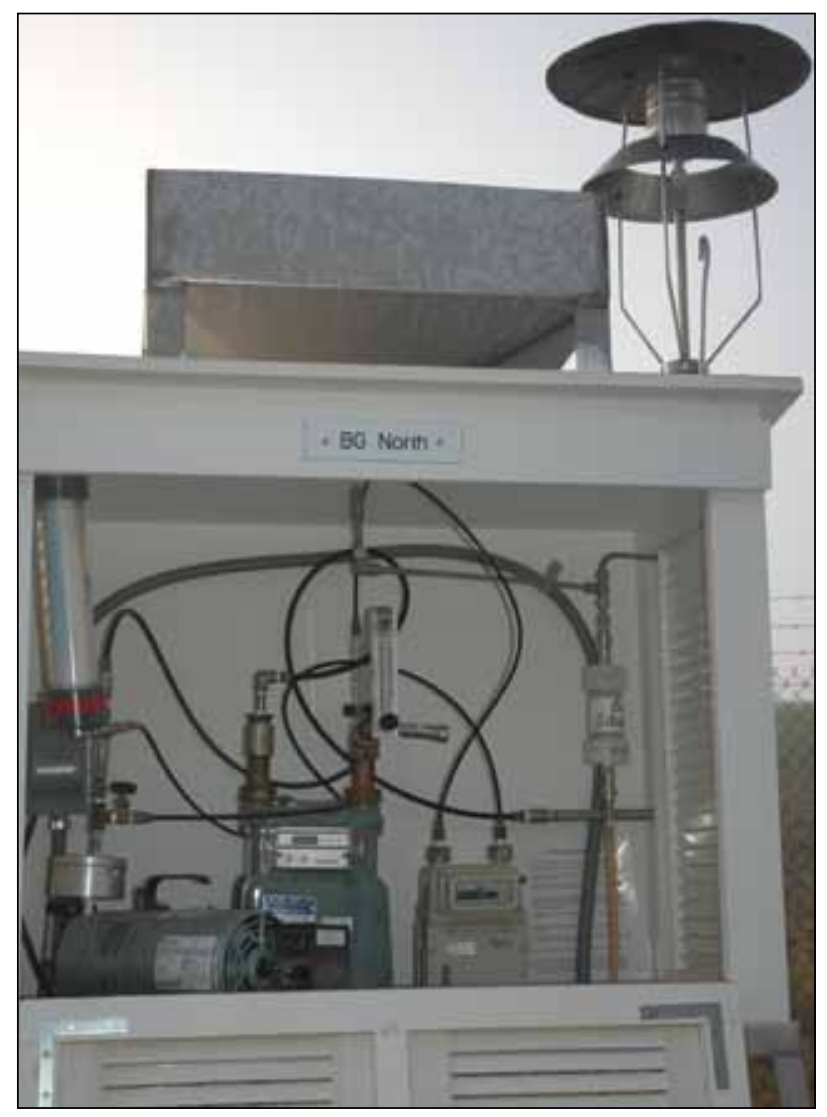

Internal (L) and External Configurations of an Air Surveillance Sampling Station 
Table 5-1 Average Gross Alpha in Air Filter Results (pCi/m³) 2006-2010

\begin{tabular}{lrrrrc|}
\hline Location & $\mathbf{2 0 0 6}$ & $\mathbf{2 0 0 7}$ & $\mathbf{2 0 0 8}$ & $\mathbf{2 0 0 9}$ & $\mathbf{2 0 1 0}$ \\
\hline Onsite & $8.79 \mathrm{E}-04$ & $1.10 \mathrm{E}-03$ & $9.45 \mathrm{E}-04$ & $9.53 \mathrm{E}-04$ & $1.17 \mathrm{E}-03$ \\
Perimeter & $1.12 \mathrm{E}-03$ & $1.17 \mathrm{E}-03$ & $9.96 \mathrm{E}-04$ & $1.03 \mathrm{E}-03$ & $1.13 \mathrm{E}-03$ \\
$25-$ mile & $1.12 \mathrm{E}-03$ & $1.03 \mathrm{E}-03$ & $9.94 \mathrm{E}-04$ & $9.95 \mathrm{E}-04$ & $1.06 \mathrm{E}-03$ \\
$100-m i l e$ & $9.99 \mathrm{E}-04$ & $9.99 \mathrm{E}-04$ & $9.12 \mathrm{E}-04$ & $9.89 \mathrm{E}-04$ & $1.13 \mathrm{E}-03$ \\
Overall Average & $1.03 \mathrm{E}-03$ & $1.07 \mathrm{E}-03$ & $9.62 \mathrm{E}-04$ & $9.91 \mathrm{E}-04$ & $1.12 \mathrm{E}-03$ \\
\hline
\end{tabular}

Table 5-2 Average Gross Beta in Air Filter Results $\left(\mathrm{pCi} / \mathrm{m}^{3}\right)$ 2006-2010

\begin{tabular}{|lrrrrc|}
\hline Location & $\mathbf{2 0 0 6}$ & $\mathbf{2 0 0 7}$ & $\mathbf{2 0 0 8}$ & $\mathbf{2 0 0 9}$ & \multicolumn{2}{c}{2010} \\
\hline Onsite & $1.51 \mathrm{E}-02$ & $1.51 \mathrm{E}-02$ & $1.51 \mathrm{E}-02$ & $1.48 \mathrm{E}-02$ & $1.63 \mathrm{E}-02$ \\
Perimeter & $1.60 \mathrm{E}-02$ & $1.57 \mathrm{E}-02$ & $1.57 \mathrm{E}-02$ & $1.51 \mathrm{E}-02$ & $1.66 \mathrm{E}-02$ \\
$25-m i l e$ & $1.53 \mathrm{E}-02$ & $1.56 \mathrm{E}-02$ & $1.56 \mathrm{E}-02$ & $1.56 \mathrm{E}-02$ & $1.69 \mathrm{E}-02$ \\
$100-m i l e$ & $1.41 \mathrm{E}-02$ & $1.34 \mathrm{E}-02$ & $1.34 \mathrm{E}-02$ & $1.32 \mathrm{E}-02$ & $1.61 \mathrm{E}-02$ \\
Overall Average & $1.51 \mathrm{E}-02$ & $1.50 \mathrm{E}-02$ & $1.50 \mathrm{E}-02$ & $1.47 \mathrm{E}-02$ & $1.65 \mathrm{E}-02$ \\
\hline
\end{tabular}

observed at other locations. BGN concentrations are expected to be higher and more variable because of the location's proximity to both the tritium facilities and to the phytoremediation project near the center of the site; the concentrations are influenced by operations at these facilities. All tritium-in-air samples from the center of the site contained detectable levels of tritium. Beyond the center of the site, tritium-in-air was detected in 82 of 363 samples. As expected, tritium concentrations generally decreased with increasing distance from the tritium facilities (figure 5-2).

\section{Rainwater}

\section{Description of Surveillance Program}

The atmospheric surveillance program also includes rainwater surveillance, which is divided into two parts: sampling for tritium and sampling for deposition (nontritium radionuclides). Tritium analysis is performed at all 15 stations, while seven of these stations are sampled for deposition. The placement of locations for deposition was selected to provide a uniform distribution around the site.

\section{Surveillance Results Summary}

No detectable manmade gamma-emitting radionuclides were observed in rainwater samples during 2010 (data table 5-4).
Gross alpha and gross beta results from 2010 were consistent with those of 2009. In 2010, the average gross alpha and gross beta results generally were slightly lower than in 2009. Annual average gross alpha and gross beta concentrations, as well as individual sample results, are consistent with historical results, which demonstrate long-term variability.

Detectable levels of uranium-234 and uranium-238 were present in 14 of 69 samples, whereas detectable levels of uranium-235 were present in only one (from the D Area location) of the 69 samples. Uranium is naturally occurring in soil, and therefore expected to be present at low concentrations in some deposition samples. Both uranium-234 and uranium-238 results were higher at the D Area perimeter location than at the other site perimeter locations; they also were higher at the BGN (onsite) location. This likely is attributable to the increased airborne particulate matter (dust) present at these locations because of vehicle traffic on nearby dirt roads and fields. Neither plutonium-238 nor plutonium-239 was observed in any of the 69 samples. Americium-241 was observed in six samples (three from the site perimeter, one from the 25-mile location, and two from the 100-mile location). The average concentration of americium-241 was well below the drinking water standard. Six 2010 strontium-89, 90 results were above the MDC — consistent with 
results since 2007, when the laboratory implemented a more sensitive analytical protocol. The strontium concentration levels were below regulatory limits.

Tritium in rainwater results showed detectable levels in 41 (21-percent) of the 191 rainwater samples for 2010 (data table 5-5). As in previous years, tritium-in-rain values were highest near the center of the site. All 13 rainwater samples from the center of the site contained detectable tritium. This is consistent with the $\mathrm{H}$ Area effluent release points that routinely release tritium. Beyond the center of the site, tritium was detected in 28 rainwater samples -26 from the site perimeter locations and two from the 25-mile location. As with tritium in air, concentrations generally decreased as distance from the effluent release points increased (figure 5-3).

\section{Gamma Radiation}

\section{Description of Surveillance Program}

Ambient gamma exposure rates in and around SRS are monitored by an extensive network of dosimeters. The site uses the thermoluminescent dosimeter (TLD) to quantify integrated gamma exposure on a quarterly basis. The TLD performs this function accurately, reliably, and relatively inexpensively.
SRS has been monitoring ambient environmental gamma exposure rates with TLDs since 1965 . The information provided by this program is used primarily to determine the impact (if any) of site operations on the gamma exposure environment and to evaluate trends in environmental exposure levels. Other potential uses include support of routine and emergency response dose calculation models.

The SRS ambient gamma radiation monitoring program is divided into four subprograms, as follows: site perimeter stations, population centers, air surveillance stations, and Vogtle (stations that monitor potential exposures from Georgia Power's VEGP). All TLDs are exchanged quarterly. Most gamma exposure monitoring is conducted on site and at the site perimeter. Monitoring continues to be conducted in population centers within approximately 9 miles $(15 \mathrm{~km})$ of the site boundary, but only limited monitoring is conducted beyond this distance and at the 25- and 100-mile air surveillance stations.

\section{Surveillance Results Summary}

Ambient gamma exposure rates at all TLD monitoring locations show some variation based on normal site-to-

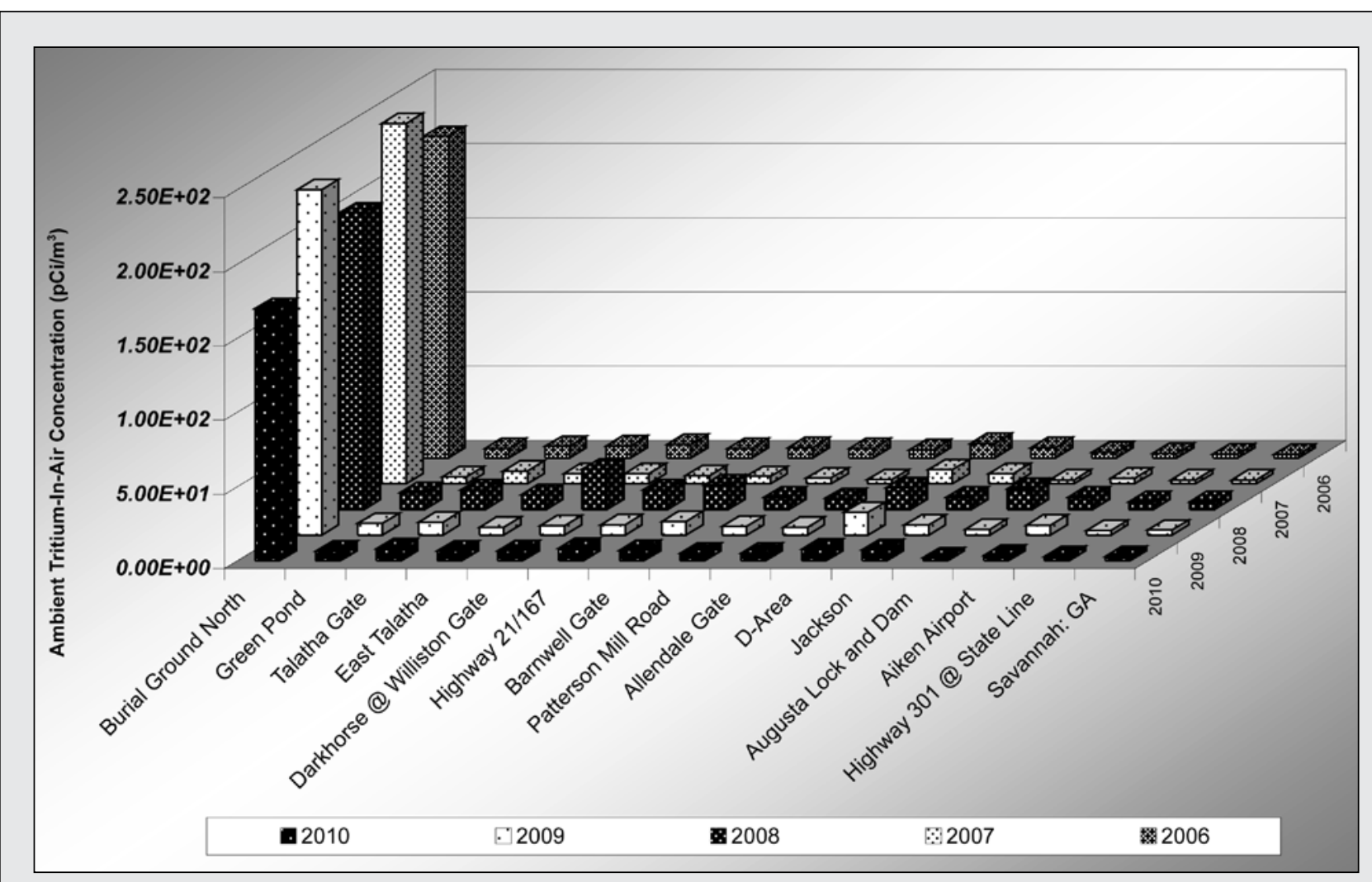

Figure 5-2 Ambient/Atmospheric Tritium-In-Air Concentrations ( $\left.\mathrm{pCi} / \mathrm{m}^{3}\right), \mathbf{2 0 0 6 - 2 0 1 0}$ 
site and year-to-year differences in the components of natural ambient gamma radiation exposure levels. In 2010, ambient gamma exposure rates varied between 64 and 129 mrem per year (data table 5-6).

In general, the 2010 ambient gamma radiation monitoring results indicated dose rates slightly higher than those observed at the same locations in 2009, with the exception of the center-of-the-site location, BGN (figure 5-4). The average annual exposure rate was 82 mrem in 2010, compared to $80 \mathrm{mrem}$ in 2009. The total ambient exposure results for the BGN (onsite) location was lower for 2010 (129 mrem per year) than for 2009 (152 mrem/year). However, these results generally are consistent with previously published historical results, and indicate that no significant difference in average annual dose rates is observed between monitoring networks - except in the case of population centers. Ambient dose rates in population centers are slightly elevated compared to the other monitoring networksas expected-because of factors such as buildings and roadways, which emit low levels of radiation.

\section{Stormwater Basins}

\section{Description of Surveillance Program}

Stormwater accumulating in site stormwater basins is monitored monthly for gross alpha, gross beta, tritium, strontium, gamma-emitting radionuclides, and actinides.
Analyses for specific radionuclides are determined by the makeup of the previous releases to the basins.

In 2010, monitoring was conducted at six E Area basins, as well as at the Z Area Basin and F Area Pond 400.

\section{Surveillance Results Summary}

There are no active discharges to site stormwater basins. The primary contributor is rainwater runoff. Rain events did not supply enough water to the E-006 basin for sampling purposes in 2010. The highest mean tritium concentration was measured in the E-005 basin, at $2.58 \mathrm{E}+04 \mathrm{pCi} / \mathrm{L}$, and was slightly lower than the highest mean tritium concentration at the same location in 2009 , which is consistent with the previous 5 years of historical results. No cobalt-60, cesium-137, or curium244 was detected in any of the basins. Fission products, as well as some actinides, were observed in the basins. Technetium-99 was detected in four locations, averaging less than $2 \mathrm{pCi} / \mathrm{L}$, with the primary actinides (uranium234, uranium-238, and plutonium-238) measuring a mean average of less than $1 \mathrm{pCi} / \mathrm{L}$. Gross alpha and gross beta activity was detected in all the basins, and the concentrations were compared to those of the previous 5 years to identify any trends. The 2010 values were consistent with historical data of the past 5 years (data table 5-7).

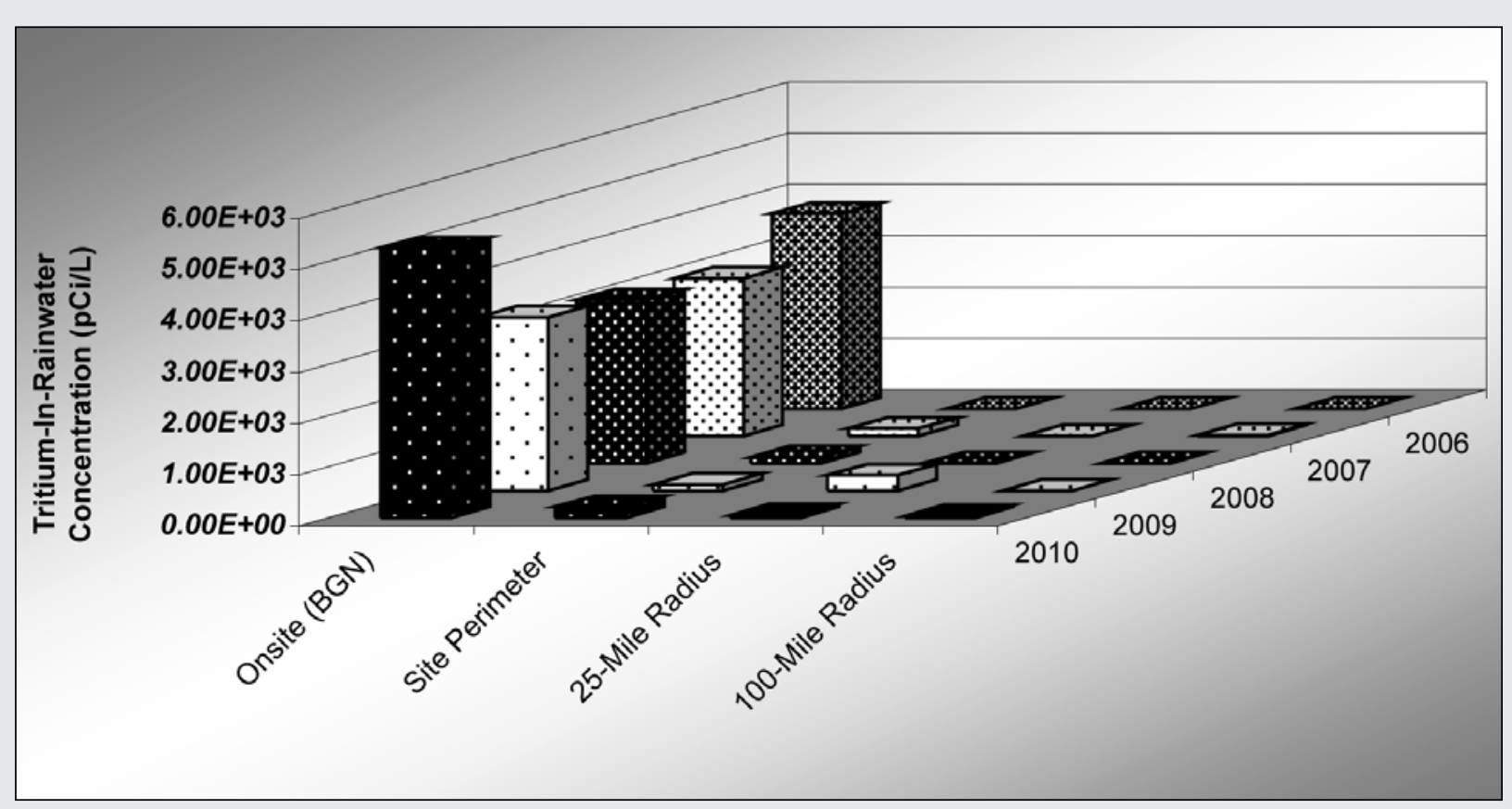

Figure 5-3 Average Tritium-in-Rainwater Concentrations, 2006-2010 


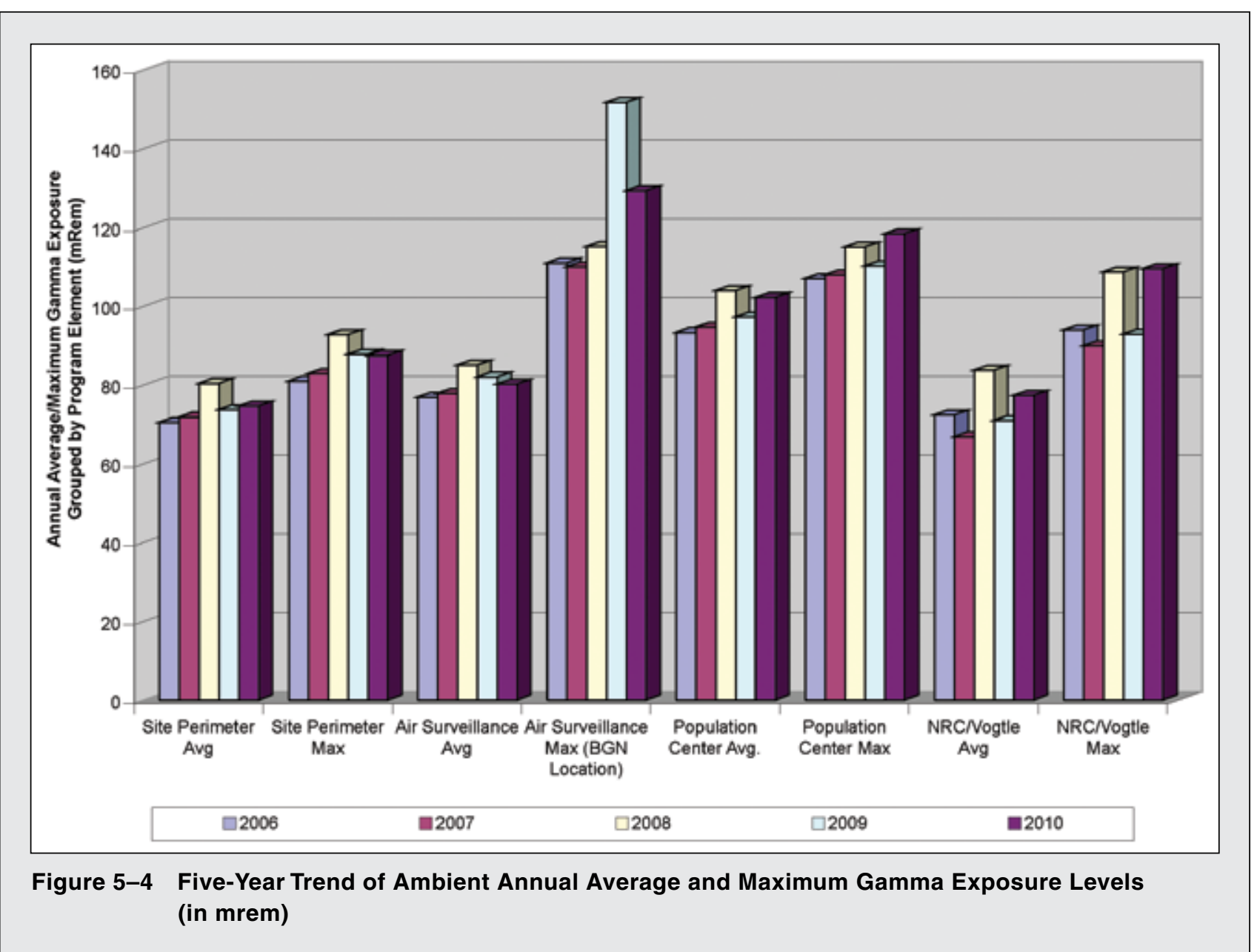

\section{Streams}

\section{Description of Surveillance Program}

Continuous surveillance monitoring of SRS streams is utilized downstream of several process areas to detect and quantify levels of radioactivity in effluents transported to the Savannah River. The five primary streams are Upper Three Runs, Fourmile Branch, Pen Branch, Steel Creek, and Lower Three Runs. The frequency and types of analyses performed on each sample are based on potential quantity and types of radionuclides likely to be present at the sampling location.

\section{Surveillance Results Summary}

The average 2010 concentrations of gross alpha, gross beta, and tritium in SRS streams are presented in table 5-3. Detectable concentrations of tritium, the predominant radionuclide detected above background levels in SRS streams, were observed at least once at all stream locations in 2010, except at Upper Three Runs-1A (the stream control point). When comparing stream tritium averages for 2010 and 2009, some were slightly higher and others were slightly lower; however, there were no statistically significant differences between the averages of the two years. Overall, tritium concentrations in SRS streams during 2010 were consistent with long-term tritium levels.

Cesium-137 was detected in four of the five major SRS streams at least once-Upper Three Runs, Fourmile Branch, Pen Branch, and Steel Creek. Gross alpha and gross beta activity was detected in all the streams, but concentrations were consistent with levels of recent years. Other radionuclides were observed at locations throughout the site, but were consistent with the source of the material - and exhibited variations similar to those of previous years. No significant trends were observed in 2010 when compared with recent years (data table 5-8), and in most cases, averages were less than 1 $\mathrm{pCi} / \mathrm{L}$.

\section{Seepage Basin and Solid Waste Disposal Facility Radionuclide Migration}

To incorporate the migration of radioactivity to site streams into total radioactive release quantities, 


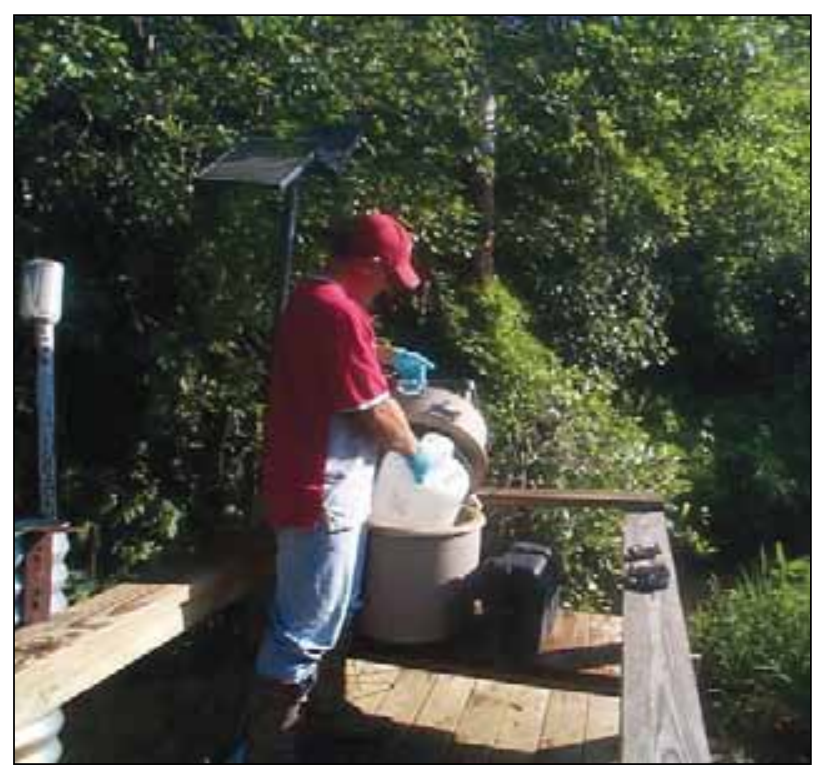

Environmental Monitoring Field Technician Collects Sample from Automated ISCO Sampler at Sampling Location Four Mile-2B

Environmental Monitoring group personnel continued to monitor and quantify the migration of radioactivity from site seepage basins and the Solid Waste Disposal Facility (SWDF) in 2010 as part of its stream surveillance program. Tritium, strontium-89,90, technetium-99, iodine-129, and cesium-137 were detected in migration releases (data table 5-9).

Figure 5-5 is a graphical representation of releases of tritium via migration to site streams for the years 20012010. As can be seen in the figure, migration releases of tritium generally have declined the past 10 years, with year-to-year variability caused mainly by the amount of annual rainfall. Accordingly, during 2010, the total quantity of tritium migrating from site seepage basins and SWDF was 1,058 Ci compared to 1,321 Ci in 2009.

Radioactivity previously deposited in the $\mathrm{F}$ Area and $\mathrm{H}$ Area seepage basins and SWDF continues to migrate through the groundwater and to outcrop into Fourmile Branch and Upper Three Runs. Groundwater migration from the F Area Seepage basins enters Fourmile Branch between locations FM-3A, FM-2B, and FM-A7.

Because of their proximity, migration from the SWDF cannot be distinguished from migration from a part of $\mathrm{H}$ Area Basin 4. Estimated migration of tritium into Fourmile Branch in 2010 occurred as follows:

- from F Area seepage basins, $34 \mathrm{Ci}$-a 26-percent increase from the 2009 total of $27 \mathrm{Ci}$

- from SWDF and a part of H Area seepage basin 4, $381 \mathrm{Ci}-\mathrm{a} 28$-percent decrease from the 2009 total of $532 \mathrm{Ci}$

- from $\mathrm{H}$ Area seepage basins 1, 2, 3, and most of 4, $85 \mathrm{Ci}-\mathrm{a} 37$-percent decrease from the 2009 total of $135 \mathrm{Ci}$

The estimated migration from the north side of SWDF and the General Separations Area (GSA) into Upper Three Runs in 2010 was $69 \mathrm{Ci}$, compared with the 2009 total of $68 \mathrm{Ci}$ - a fluctuation consistent with historical results. (The GSA is in the central part of SRS and contains all waste disposal facilities, chemical separations facilities, and associated high-level waste storage facilities, along with numerous other sources of radioactive material.)

\section{Table 5-3 Average 2010 Concentrations of Radioactivity in SRS Streams}

\begin{tabular}{|lccc|}
\hline Location & $\begin{array}{c}\text { Gross Alpha } \\
\text { (pCi/L) }\end{array}$ & $\begin{array}{c}\text { Gross Beta } \\
\text { (pCi/L) }\end{array}$ & $\begin{array}{c}\text { Tritium } \\
\text { (pCi/L) }\end{array}$ \\
\hline Onsite Downstream Locations & & & \\
Tims Branch (TB-5) & $1.80 \mathrm{E}+01$ & $6.23 \mathrm{E}+00$ & $4.07 \mathrm{E}+02$ \\
Lower Three Runs (L3R-3) & $3.06 \mathrm{E}+00$ & $2.11 \mathrm{E}+00$ & $2.60 \mathrm{E}+02$ \\
Steel Creek (SC-4) & $2.09 \mathrm{E}+00$ & $2.02 \mathrm{E}+00$ & $2.83 \mathrm{E}+03$ \\
Pen Branch (PB-3) & $8.42 \mathrm{E}-01$ & $1.07 \mathrm{E}+00$ & $3.56 \mathrm{E}+04$ \\
Fourmile Branch (FM-6) & $6.95 \mathrm{E}-01$ & $6.66 \mathrm{E}+00$ & $4.03 \mathrm{E}+04$ \\
Upper Three Runs (U3R-4) & $8.33 \mathrm{E}+00$ & $2.90 \mathrm{E}+00$ & $1.02 \mathrm{E}+03$ \\
Onsite Control Location (for comparison purposes) & & & \\
Upper Three Runs (U3R-1A) & $4.74 \mathrm{E}+00$ & $1.94 \mathrm{E}+00$ & $1.93 \mathrm{E}+02$ \\
\hline
\end{tabular}




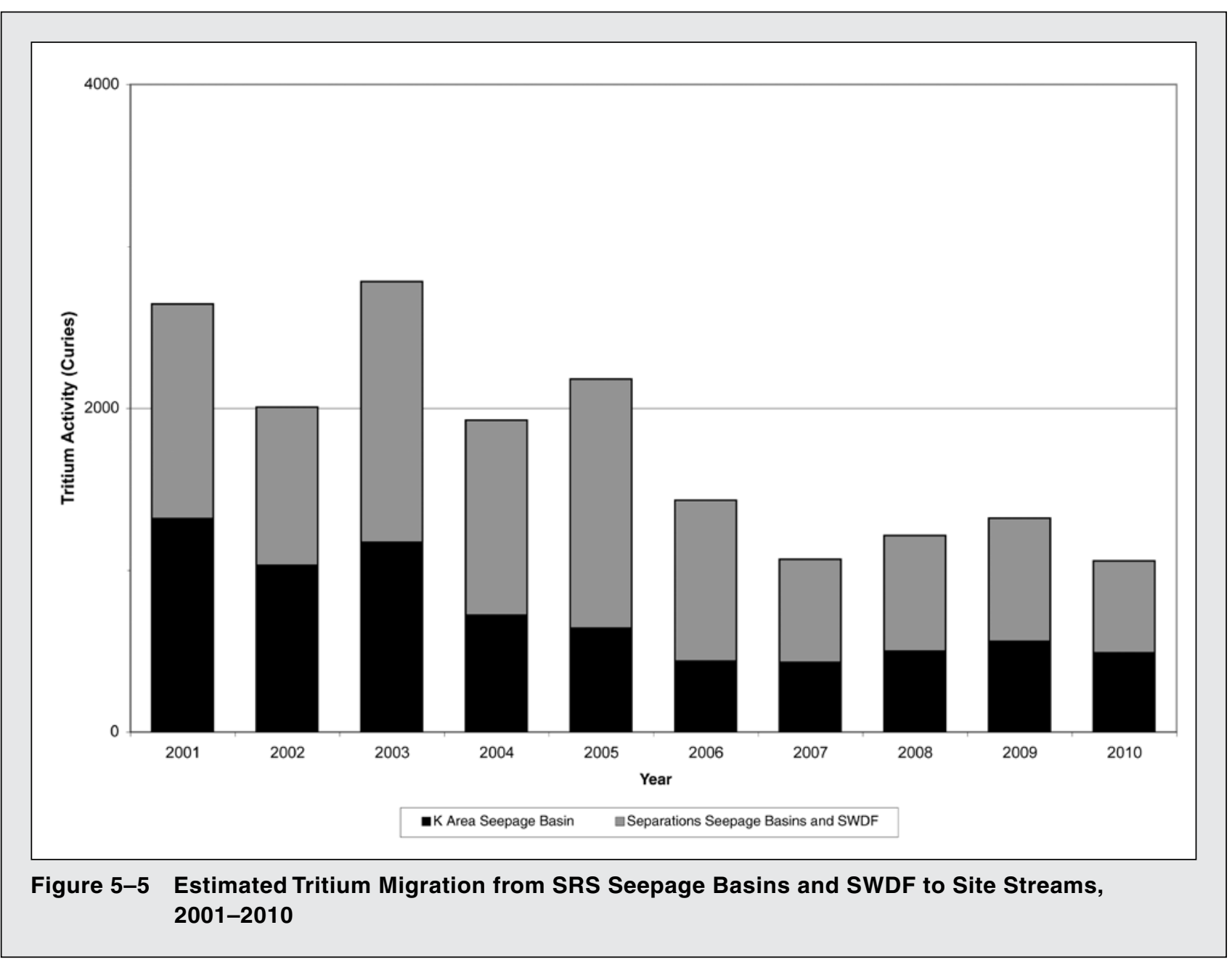

The total amount of strontium-89,90 entering Fourmile Branch from the GSA seepage basins and SWDF during 2010 was estimated to be $26 \mathrm{mCi}$ (table 5-4). Migration releases of strontium-89,90 vary from year to year but have remained below $100 \mathrm{mCi}$ the past 8 years. In $2010,13 \mathrm{mCi}$ of technetium-99, $23 \mathrm{mCi}$ of iodine129 , and $37 \mathrm{mCi}$ of cesium-137 were estimated to have migrated into Fourmile Branch (table 5-4).

\section{K Area Drain Field and Seepage Basin Liquid} purges from the K Area disassembly basin were released to the $\mathrm{K}$ Area seepage basin in 1959 and 1960. From 1960 until 1992, purges from the K Area disassembly basin were discharged to a percolation field below the K Area retention basin. Tritium migration from the seepage basin and the percolation field is measured annually in Pen Branch. The 2010 estimated migration total of $489 \mathrm{Ci}$ represents a 12.5-percent decrease from the $559 \mathrm{Ci}$ recorded in 2009.
C Area, L Area, and P Area Seepage Basins Liquid purges from the C Area, L Area, and P Area disassembly basins were released periodically to their respective seepage basins from the 1950s until 1970. Migration releases from these basins are accounted for in the stream transport totals (see "Tritium Transport in Streams" section of this chapter).

\section{Migration of Actinides in Streams}

Migration of the actinides uranium, plutonium, americium, and curium into site streams no longer is quantified because of the actinides' historically low levels. However, the streams are sampled and analyzed annually for the presence of these actinides. The resulting concentrations are compared to those of previous years to identify any trends. Overall, values for 2010 were consistent with historical data, and generally remained at or below the analytical MDC. 
Table 5-4 Strontium-89,90, Technetium-99, lodine-129, and Cesium-137 Migration Estimates

\begin{tabular}{|lc|}
\hline Radionuclide & $\begin{array}{c}\text { Total Activity } \\
\text { (millicuries) }\end{array}$ \\
\hline Strontium-89,90 & 26 \\
\hline Technetium-99 & 13 \\
lodine-129 & 23 \\
Cesium-137 & 37 \\
\hline
\end{tabular}

${ }^{\mathrm{a}} 1$ millicurie $=0.001$ Curie

\section{Savannah River}

\section{Description of Surveillance Program}

Continuous surveillance is performed along the Savannah River at locations above and below SRS tributaries, including a location at which liquid discharges from VEGP enter the river.

\section{Surveillance Results Summary}

Five locations along the river continued to serve as environmental surveillance points in 2010. Composite samples are collected weekly at the five river locations and analyzed for gross alpha, gross beta, tritium, and gamma-emitting radionuclides (data table 5-10). The average 2010 concentrations of gross alpha, gross beta, and tritium at river locations are presented in table 5-5. Based on curies (of activity) released, tritium is the predominant radionuclide detected above background levels in the Savannah River. The combined SRS and VEGP tritium concentrations at Savannah River Mile (RM) 118.8 decreased by 12 percent, from 2,350 $\mathrm{Ci}$ in 2009 to 2,060 $\mathrm{Ci}$ in 2010. These concentration levels are well below the EPA drinking water standard. Detectable levels of gross alpha and gross beta activity were observed at all river sampling locations and were consistent with the averages of the previous 5 years. Cesium-137 was detected in one out of the 265 weekly composite river samples for 2010 .
In addition to the weekly composite samples referenced above, SRS collects annual grab samples to provide a more comprehensive suite of radionuclides (strontium-89,90, technetium-99 and actinides). Uranium-234, uranium-238 and americium-241 were quantified in all these grab samples from RM 118.8 and several other locations in 2010. Results were consistent with the averages of the previous 5 years.

\section{Tritium Transport in Streams}

Tritium is introduced into SRS streams and the Savannah River from former production areas on site. Because of the mobility of tritium in water and the quantities of the radionuclide released during the years of SRS operations, a tritium balance has been performed annually since 1960 . SRS tritium transport data for 1960-2010 are depicted in figure 5-6, which shows the history of direct releases, stream transport, and river transport, as determined by Environmental Monitoring personnel. The history of tritium transport at SRS is documented in data table 5-11. The balance is evaluated among the following alternative methods of calculation:

- total direct tritium releases, including releases from (1) facility effluent discharges and (2) measured migration of tritium from site seepage basins and SWDF migration (direct releases)

- tritium transport in SRS streams, measured at the last sampling point before entry into the Savannah River (stream transport)

- tritium transport in the Savannah River, measured downriver of SRS (near RM 118.8) after subtraction of any measured contribution above the site (river transport)

The direct releases of tritium in 2010 decreased by approximately 18-percent (from 1,559 $\mathrm{Ci}$ in 2009 to $1,285 \mathrm{Ci}$ in 2010).

The stream transport of tritium in 2010 decreased by approximately 5-percent (from 1,271 Ci in 2009 to 1,205 $\mathrm{Ci}$ in 2010).

Table 5-5 Average 2010 Concentrations of Radioactivity in the Savannah River

\begin{tabular}{|cccc|}
\hline Location & Gross Alpha (pCi/L) & Gross Beta (pCi/L) & Tritium (pCi/L) \\
\hline RM-160.0 & $3.83 E-01$ & $2.20 \mathrm{E}+00$ & $9.83 \mathrm{E}+01$ \\
RM-150.4 & $9.28 \mathrm{E}-01$ & $2.73 \mathrm{E}+00$ & $6.34 \mathrm{E}+02$ \\
RM-150.0 & $3.86 \mathrm{E}-01$ & $2.22 \mathrm{E}+00$ & $2.77 \mathrm{E}+02$ \\
RM-141.5 & $4.87 \mathrm{E}-01$ & $2.19 \mathrm{E}+00$ & $3.62 \mathrm{E}+02$ \\
RM-118.8 & $4.64 \mathrm{E}-01$ & $2.35 \mathrm{E}+00$ & $3.49 \mathrm{E}+02$ \\
\hline
\end{tabular}




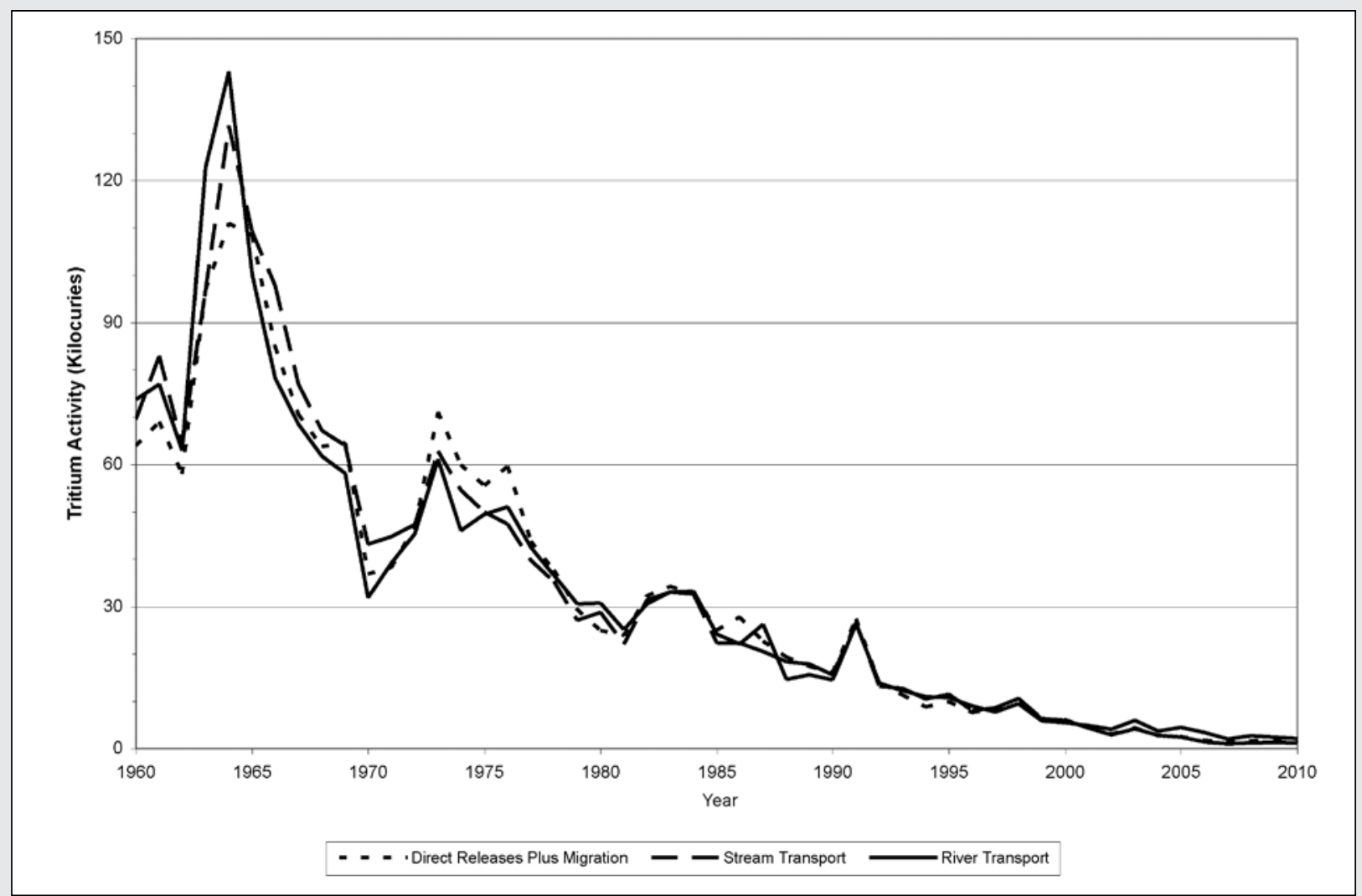

Figure 5-6 SRS Tritium Transport Summary, 1960-2010

SRS has maintained a tritium balance of direct releases plus migration, stream transport, and river transport since 1960 in an effort to account for and trend tritium releases in liquid effluents from the site. The general trend over time is attributable to (1) variations in tritium production at the site (production discontinued in the late 1980s); (2) the implementation of effluent controls, such as seepage basins, beginning in the early 1960s; and (3) the continuing depletion and decay of the site's tritium inventory.

The river transport of tritium estimated in the Savannah River in 2010 was $2,058 \mathrm{Ci}$, compared with the previous year's 2,350 Ci. Both VEGP and SRS contributed to these values.

As it has during the past several years, a small but measurable amount of tritium from earlier EnergySolutions LLC (formerly Chem-Nuclear Systems) low-level radioactive waste disposal facility operations entered the stream system in 2010. The facility is privately owned and located adjacent to SRS. The amount of tritium entering the system is expected to continue a gradual decline over time. EnergySolutions LLC began a program of capping the tritium sources in 1991, thereby reducing the amount of tritium entering the groundwater. The tritium currently in groundwater will continue to decay and dilute as it moves from the source toward Lower Three Runs. Environmental Monitoring and EnergySolutions will maintain a monitoring program for Lower Three Runs to evaluate this tritium migration.

\section{Domestic Water Description of Surveillance Program}

Environmental Monitoring personnel collected domestic water samples in 2010 from locations at SRS and at water treatment facilities that use Savannah River water. Potable water was analyzed at offsite treatment facilities to ensure that SRS operations did not adversely affect the water supply and to provide voluntary assurance that drinking water did not exceed EPA drinking water standards for radionuclides.

Onsite domestic water sampling consisted of quarterly grab samples at large treatment plants in A Area, D Area, and K Area and annual grab samples at wells and small systems. Composite samples were collected monthly off site from

- $\quad$ the Beaufort-Jasper Water and Sewer Authority's Chelsea and Purrysburg Water Treatment Plants

- the City of Savannah Industrial and Domestic Water Supply Plant 


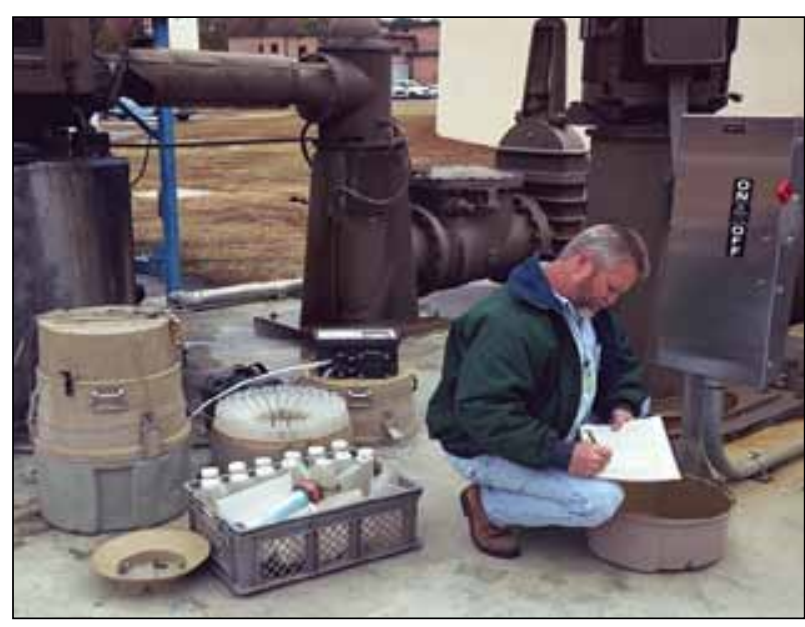

Environmental Monitoring Field Technician Collects Drinking Water Samples from Beaufort/ Jasper Purrysburg Plant

- the North Augusta (South Carolina) Water Treatment Plant

\section{Surveillance Results Summary}

All onsite and offsite domestic water samples collected by Environmental Monitoring in 2010 were screened for gross alpha and gross beta concentrations to determine if regulatory limits are exceeded. No domestic water exceeded EPA's 15-pCi/L alpha activity limit or 50-pCi/ $\mathrm{L}$ beta activity limit. Also, no onsite or offsite domestic water samples exceeded the 20,000-pCi/L EPA tritium limit or the $8-\mathrm{pCi} / \mathrm{L}$ strontium-89,90 MDC.

No cesium-137, uranium-235, plutonium-239, or curium244 was detected in any domestic water samples in 2010. For the 14 onsite samples, detectable levels were observed for strontium-89,90 in two samples, plutonium-238 in seven samples, americium-241 in one sample, uranium-234 in five samples, and uranium-238 in two samples (data table 5-12).

\section{Terrestrial Food Products}

\section{Description of Surveillance Program}

The terrestrial food products surveillance program consists of radiological analyses of food product samples typically found in the Central Savannah River Area (CSRA). Because radioactive materials can be transported to man through the consumption of milk and other food products containing radioactivity, food product samples are analyzed to determine the effects, if any, that SRS operations have on them. These foods include milk, meat (beef), fruit (melons or peaches), and green vegetables (collards). Data from the food product surveillance program are not used to show direct compliance with any dose standard; however, the data can be used as required to validate dose models and determine environmental trends.

Samples of food - including meat, fruit, and a green vegetable - are collected from one location within each of four SRS quadrants and from a location within an extended (to 25 miles beyond the perimeter) southeast quadrant. All food samples are collected annually except milk, which is collected quarterly from six dairies within a 25 -mile radius of the site. The food product surveillance program was expanded in 2005 to include secondary crops on a rotating schedule. Cabbage was sampled in 2010 as part of this program. Wheat originally was scheduled to be collected during 2010 as a rotational crop, but was unavailable in all quadrants. Food samples typically are analyzed for the presence of gamma-emitting radionuclides, tritium, strontium-89,90, uranium-234, uranium-235, uranium238, plutonium-238, plutonium-239, americium-241, curium-244, gross alpha activity, and gross beta activity. Technetium-99 was added to analytical suite in 2009, and neptunium in 2010.

\section{Surveillance Results Summary}

Terrestrial food product results for collards, cabbage, fruit, and beef appear in data table 5-13; results for milk appear in data table 5-14.

The only gamma-emitting radionuclide detected in food products in 2010 was cesium-137, as follows:

- collards from the northwest and southwest quadrants ( $0-10$ miles from the site)

- cabbage from the northwest and southeast quadrants (0-10 miles from the site)

- fruit from the plant perimeter northwest quadrant

- one milk sample from Barnwell

The levels were consistent with levels observed historically.

Strontium- 89,90 was detected in collards and cabbage at all five locations, in milk at two locations (Denmark, South Carolina, and McBean, Georgia), and in fruit at one location (plant perimeter northeast quadrant). Uranium-234 was detected in collards and cabbage at all locations, in fruit at the plant perimeter northeast quadrant, and in beef at the northeast and southwest quadrants $0-10$ miles from the site. Uranium-235 was detected in collards at the southeast quadrant $0-10$ miles from the site, and cabbage at the northeast, northwest, and southeast quadrants $0-10$ miles from the site. Uranium-238 was detected in collards and cabbage 
at all locations, in beef at the northeast, northwest, and southeast quadrants $0-10$ miles from the site, and in fruit at the plant perimeter northwest quadrant. Plutonium-239 was detected in cabbage at the northeast quadrant $0-10$ miles from the site. Curium-244 was detected in beef at the southwest quadrant $0-10$ miles from the site. Technetium-99 was detected in cabbage and collards at all locations and in beef at the northeast and northwest quadrants $0-10$ miles from the site and at the southeast quadrant 25 miles from the site. Detectable levels of gross beta activity were observed in all food products, while no detectable levels of gross alpha were observed in any of the food products. The 2010 results appeared to be randomly distributed among the monitoring locations, and no underlying spatial distribution was observed.

Tritium in food products is attributed primarily to releases from SRS. Tritium was detected during 2010 in cabbage at four locations from all four quadrants 0-10 miles from the site, in collards at the northeast, southeast, and southwest quadrants $0-10$ miles from the site, in fruit at the southeast quadrant 25 miles from the site, and in beef at the northwest quadrant $0-10$ miles from the site.

All radiological results on terrestrial food products were consistent with those of previous years.

\section{Aquatic Food Products Description of Surveillance Program}

The aquatic food product surveillance program includes fish (freshwater and saltwater) and shellfish. To determine the potential dose and risk to the public from consumption, both types are sampled. Because of a die-off attributed to cold weather in December 2009 and January 2010, no spotted sea trout could be collected. Nine surveillance points for the collection of freshwater fish are located on the Savannah River-from above SRS at Augusta, Georgia, to the coast at Savannah. Composite samples - comprised of three to five fish of a given species - are prepared for each species from each location. Freshwater fish are grouped into one of three categories: bass, panfish (bream), or catfish. Saltwater fish include composites of sea trout, red drum (spottail bass), and mullet. The fish are selected for sampling because they are the most sought-after fish in the Savannah River. Composites are divided into edible (meat and skin only) and nonedible (scales, head, fins, viscera, bone) portions; however, catfish are skinned, and the skin becomes part of the nonedible composite. Analyses conducted on edible and nonedible composites include tritium, gross alpha, gross beta, gamma emitting radionuclides, strontium-89,90, technetium-99, iodine-
129, and the actinide series (uranium-234, uranium-235, and uranium-238; neptunium-237; plutonium-238 and plutonium-239; americium-241; and curium-244).

\section{Surveillance Results Summary}

Aquatic food product results for saltwater fish appear in data table 5-15; for freshwater fish, data table 5-16; and for shellfish, data table 5-17.

Gross alpha activity was detected in one nonedible saltwater fish composite of marine mullet at the mouth of the Savannah River; all other saltwater and freshwater edible and nonedible fish composites were below their respective MDCs for gross alpha activity. Gross beta activity was detectable at all locations and was attributed primarily to the naturally occurring radionuclide potassium-40. Cesium-137 and iodine-129 were the only manmade gamma-emitting radionuclide found in Savannah River edible and nonedible fish composites during 2010. Strontium-89,90, uranium234, uranium-238, plutonium-238, and tritium were detected in freshwater fish at most of the river locations. Concentrations were similar to those of previous years. For the edible fish composites, technetium-99 was detected at 12 river locations and both plutonium-238 and uranium-238 were detected at one river location. Uranium-234, uranium-235, uranium-238, iodine-129, and strontium-89,90 were detected in saltwater fish.

Gross alpha and gross beta activity was detected in shellfish at levels that have been observed historically. Strontium-89,90, uranium-234, uranium-235, uranium238, and curium-244 also were detected in shellfish. Concentrations were similar to those of previous years.

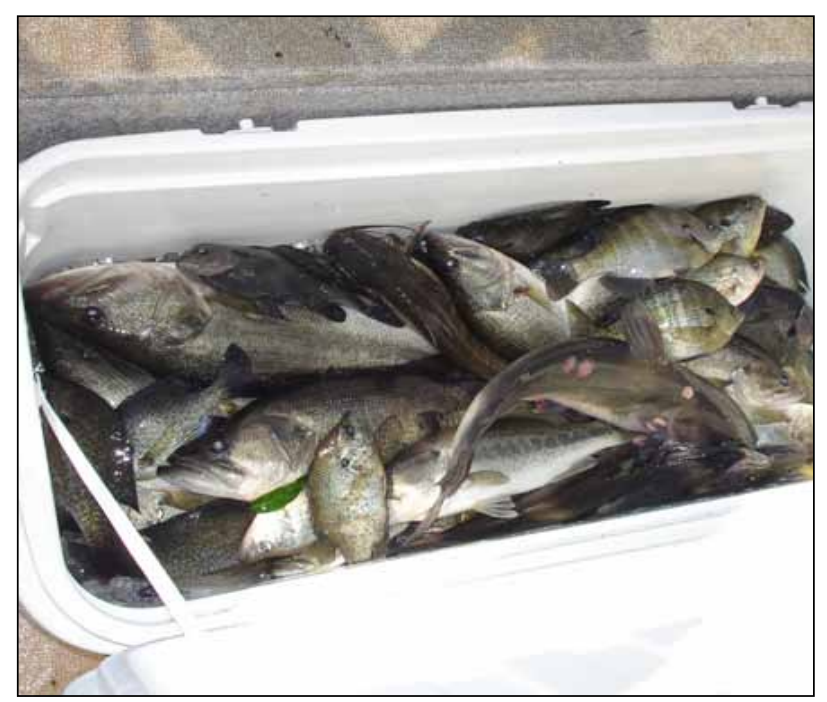

Freshwater Fish Collected During Fish Sampling Run 


\section{5 - Environmental Surveillance}

Calculations of risk from the consumption of fish from the Savannah River can be found in chapter 6 ("Potential Radiation Doses").

\section{Deer and Hogs}

\section{Description of Surveillance Program}

Annual hunts, open to members of the general public, are conducted at SRS to control the site's deer and feral hog populations and to reduce animal-vehicle accidents. Before any animal is released to a hunter, Environmental Monitoring personnel use portable sodium iodide detectors to perform field analyses for cesium-137. Media samples (muscle and/or bone) are collected periodically for laboratory analysis based on a set frequency, on cesium-137 levels, and/or on exposure limit considerations. SRS established an administrative dose limit of 30 mrem per year in 2006 for the consumption of game animals. This limit, which ensures that no single pathway contributes more than 30 percent to the all-pathway dose limit of $100 \mathrm{mrem}$, is consistent with DOE guidance. The doses from deer and hog consumption are quantified and reported in chapter 6 .

\section{Surveillance Results Summary}

A total of 502 deer and 107 feral hogs were taken during the 2010 site hunts. As observed during previous hunts, cesium-137 was the only manmade gamma-emitting radionuclide detected during laboratory analysis. Generally, the cesium-137 concentrations measured by the field and lab methods were comparable. Field measurements from all animals ranged from $1 \mathrm{pCi} / \mathrm{g}$ to $2.99 \mathrm{pCi} / \mathrm{g}$, while lab measurements ranged from $1 \mathrm{pCi} / \mathrm{g}$ to $3.35 \mathrm{pCi} / \mathrm{g}$. The average field cesium-137 concentration was $1.00 \mathrm{pCi} / \mathrm{g}$ in deer (with a maximum of $2.99 \mathrm{pCi} / \mathrm{g}$ ) and $1.00 \mathrm{pCi} / \mathrm{g}$ in hogs (with a maximum of $2.14 \mathrm{pCi} / \mathrm{g}$ ). This range of concentrations is slightly below normal for the site's deer and hog populations. Maximum cesium-137 concentrations in wildlife (deer and hogs) have indicated an overall decreasing trend, as shown in figure 5-7. Average cesium-137 concentrations in deer and hogs for the past five years reveal a similar decreasing trend, as shown in figure 5-8.

The muscle and bone samples from a subset of the animals returned to the lab for cesium-137 analysis

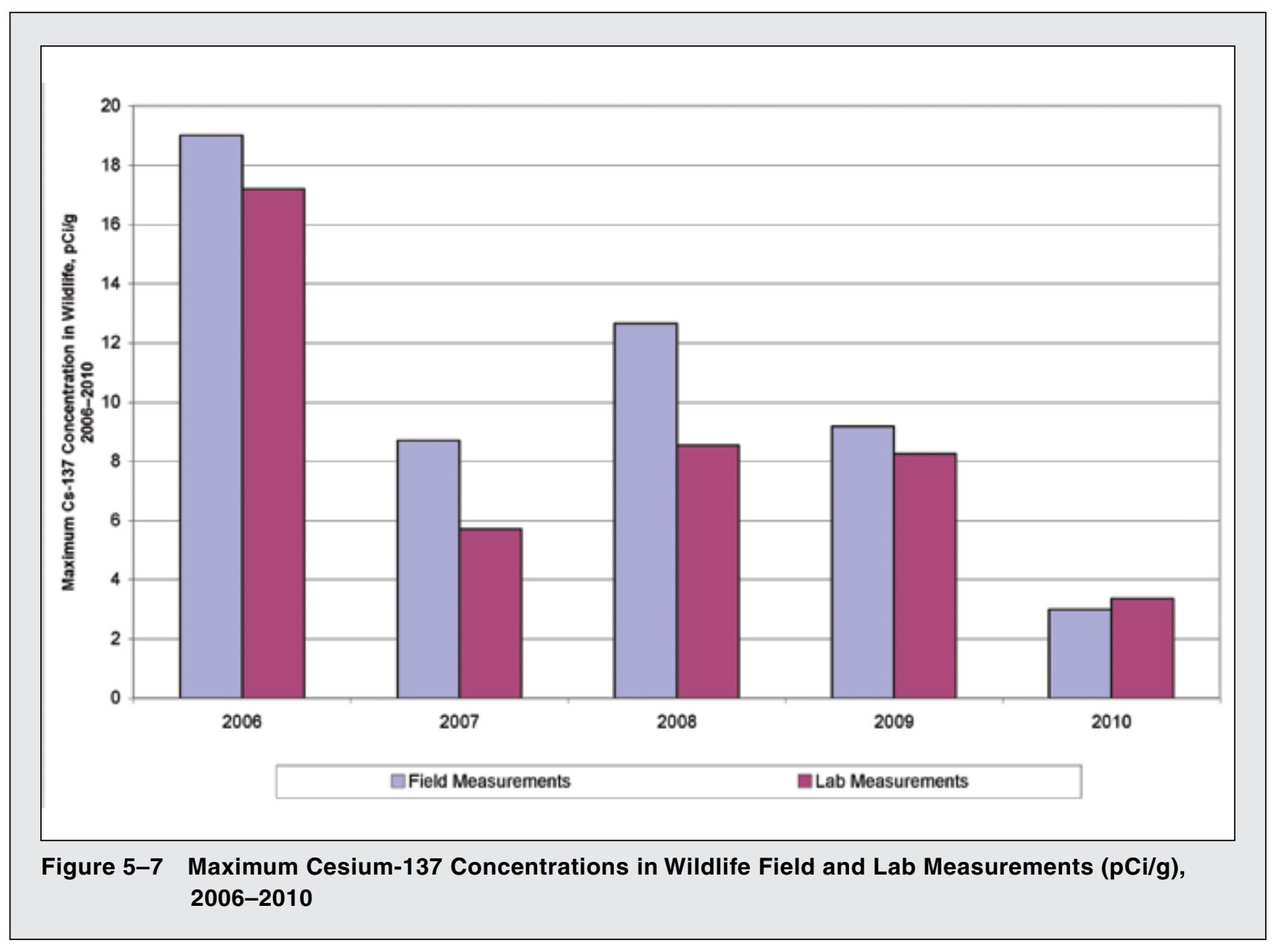




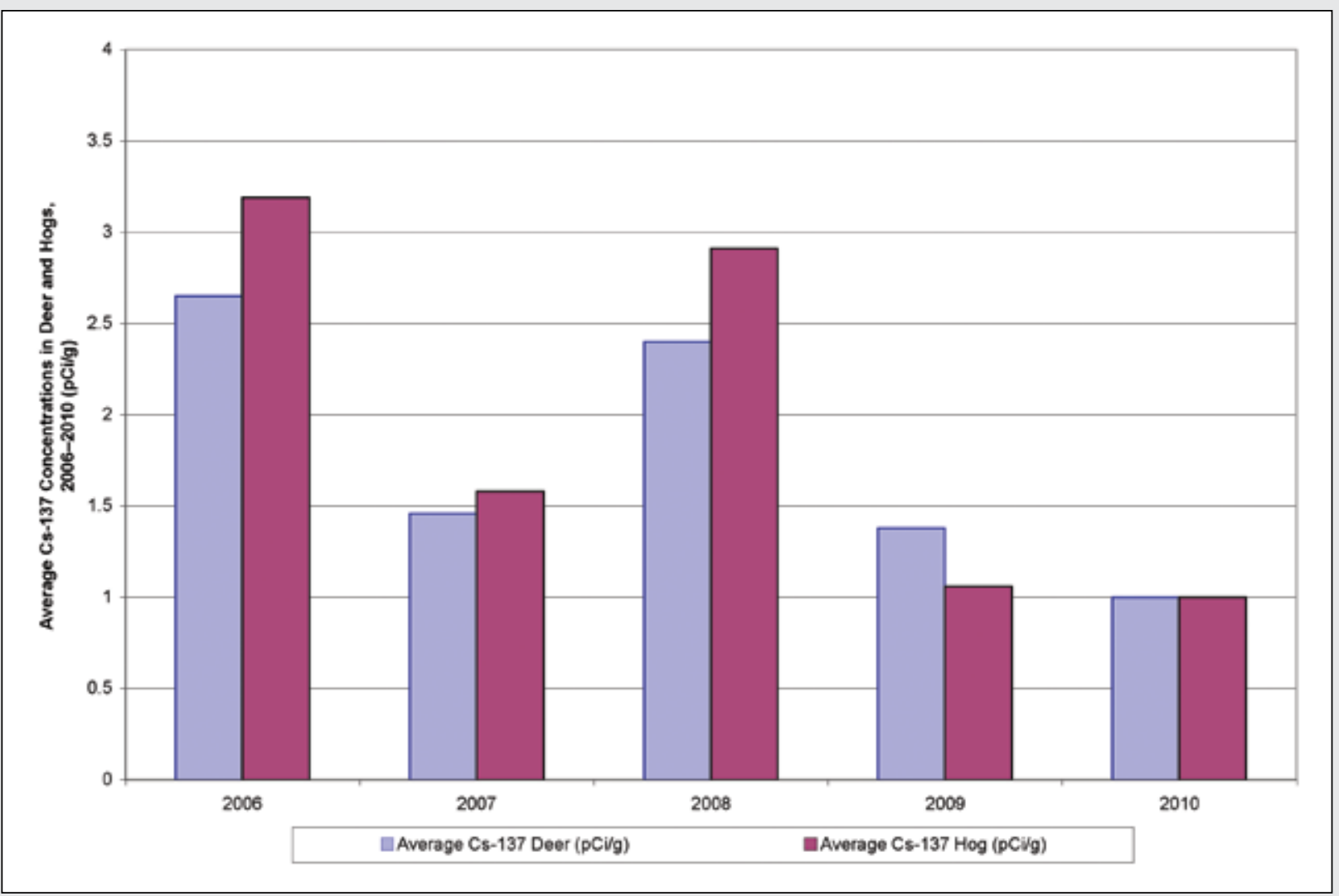

Figure 5-8 Average Cesium-137 Concentrations in Deer and Hogs (pCi/g), 2006-2010

also are analyzed for strontium-89,90. Because of its chemistry, strontium is more readily measured in bone than in muscle tissue. In 2010, strontium-89,90 was detected in 33 of 73 deer muscle tissue samples; none was detected in hog muscle tissue samples. These positive results for deer tissue samples were slightly above the MDC for strontium. Lab measurements of strontium-89,90 in bone ranged from below the MDC to $8.78 \mathrm{pCi} / \mathrm{g}$ in deer. No strontium- 89,90 was detected in any of the hog bone samples for 2010. These results are similar to those of previous years.

\section{Turkeys/Beavers}

\section{Description of Surveillance Programs}

SRS hosted a special turkey hunt during April 2010 for hunters with mobility impairments. Forty-two turkeys were harvested. The average cesium-137 concentration measured in the field was $1.30 \mathrm{pCi} / \mathrm{g}$, which is comparable with the results from previous special hunts.

The U.S. Department of Agriculture Forest ServiceSavannah River (USFS-SR) harvests beavers in selected areas within the SRS perimeter to reduce the population and thereby minimize dam-building activities that can result in flood damage to timber stands, to primary and secondary roads, and to railroad beds. USFS-SR harvested 17 beavers in FY2010 from six locations. Because none of these animals were taken from suspect radiological areas, no monitoring was performed, and they were disposed of in an onsite landfill.

\section{Soil}

\section{Description of Surveillance Program}

The SRS soil monitoring program provides

- data for long-term trending of radioactivity deposited from the atmosphere (both wet and dry deposition)

- information on the concentrations of radioactive materials in the environment

Concentrations of radionuclides in soil vary greatly among locations because of differences in rainfall patterns and in the mechanics of retention and transport in different types of soils. Therefore, a direct comparison of data from year to year is not appropriate. However, 


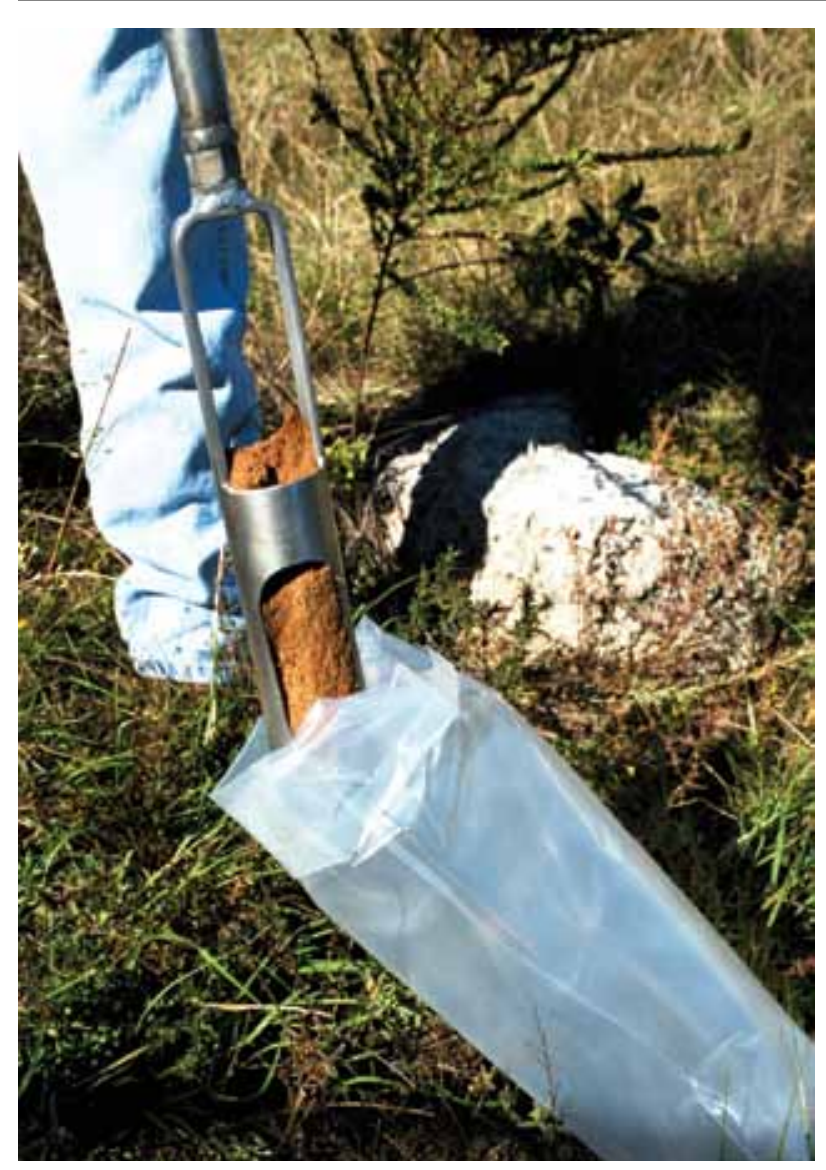

Soil Sampling at Aiken Airport Location

the data are available in previous environmental reports and can be evaluated over a period of years to determine and analyze long-term trends.

Hand augers or other similar devices are used in soil sample collection to a depth of 3 inches. The samples are analyzed for gamma-emitting radionuclides, strontium-89,90, and the actinides.

\section{Surveillance Results Summary}

In 2010, radionuclides were detected in soil samples from all 21 sampling locations (five onsite, 12 at the perimeter, and four offsite), as follows:

- cesium-137 at 15 locations (two onsite, nine perimeter, four offsite)

- uranium-234 at all 21 locations

- uranium-235 at all 21 locations

- uranium-238 at all 21 locations

- neptunium-237 at five locations (two onsite, three offsite)

- plutonium-238 at eight locations (three onsite, one perimeter, four offsite)
- plutonium-239 at 13 locations (five onsite, four perimeter, four offsite)

- strontium-89,90 at four locations (three perimeter, one offsite)

- americium-241 at five locations (two onsite, two perimeter, one offsite)

- curium-244 at four locations (one onsite, three perimeter)

The concentrations at these locations are consistent with historical results (data table 5-18). Uranium is naturally occurring in soil and therefore expected to be present in soil samples.

\section{Settleable Solids \\ Description of Surveillance Program}

Settleable-solids monitoring in effluent water is required to determine - in conjunction with routine sediment monitoring - whether a long-term buildup of radioactive materials occurs in stream systems.

DOE limits on radioactivity levels in settleable solids are $5 \mathrm{pCi} / \mathrm{g}$ above background for alpha-emitting radionuclides and $50 \mathrm{pCi} / \mathrm{g}$ above background for beta/ gamma-emitting radionuclides.

Low total suspended solids (TSS) levels result in a small amount of settleable solids, so an accurate measurement of radioactivity levels in settleable solids is not practical. Based on this, an interpretation of the radioactivitylevels-in-settleable-solids requirement was provided to SRS by DOE in 1995. The interpretation indicated that TSS levels below 40 parts per million (ppm) were considered to be in de-facto compliance with the DOE limits.

To determine compliance with these limits, Environmental Monitoring uses TSS results - gathered as part of the routine National Pollutant Discharge Elimination System (NPDES) monitoring programfrom outfalls colocated at or near radiological effluent points. If an outfall shows that TSS levels regularly are greater than $30 \mathrm{ppm}$, a radioactivity-levels-in-settleablesolids program and an increase in sediment monitoring is implemented.

\section{Surveillance Results Summary}

In 2010, no NPDES TSS sample result exceeded $30 \mathrm{ppm}$. The highest result was $24 \mathrm{ppm}(24 \mathrm{mg} / \mathrm{L})$, collected in April at outfall D-1D. The 2010 NPDES TSS results indicate that overall, SRS remains in compliance with the DOE radioactivity-levels-in-settleable-solids requirement. 


\section{Sediment}

\section{Description of Surveillance Program}

Sediment sample analysis measures the movement, deposition, and accumulation of long-lived radionuclides in stream beds and in the Savannah River bed. Significant year-to-year differences may be evident because of the continuous deposition and remobilization occurring in the stream and river beds - or because of slight variations in sampling locations-but the data obtained can be used to observe long-term environmental trends.

Sediment samples were collected at eight Savannah River and 19 onsite stream locations in 2010.

\section{Surveillance Results Summary}

Cesium-137 was the only manmade gamma-emitting radionuclide observed in river and stream sediments during 2010. The highest cesium-137 concentration in streams, $105 \mathrm{pCi} / \mathrm{g}$, was detected in sediment from R-Canal (100-R Location); the lowest levels were below detection at nine locations. The highest level from the river, $0.59 \mathrm{pCi} / \mathrm{g}$, was at River Mile 129 ; the lowest levels were below detection at five locations. Generally, cesium-137 concentrations were higher in stream sediments than in river sediments. This is to be expected because the streams receive radionuclidecontaining liquid effluents from the site. Most radionuclides settle out and deposit on the stream beds or at the streams' entrances to swamp areas along the river.Strontium-89,90 was above the MDC in sediment at 11 stream locations in 2010 . The maximum detected value was $2.00 \mathrm{pCi} / \mathrm{g}$ at the Fourmile Branch Swamp Discharge location.

Plutonium-238 was detected in sediment during 2010 at 10 stream locations and two river locations. The results ranged from a maximum of $1.04 \mathrm{pCi} / \mathrm{g}$ at $\mathrm{FM}-2 \mathrm{~A}$ at Road 4 to below the MDC at several locations. Plutonium-239 was detected in sediment at 15 stream locations and one river location. The maximum value was $0.0075 \mathrm{pCi} / \mathrm{g}$ - at FM-A7A. Uranium-234, uranium235 , and uranium-238 were detected at most locations; the maximum values were $2.47 \mathrm{pCi} / \mathrm{g}, 0.125 \mathrm{pCi} / \mathrm{g}$, and $2.52 \mathrm{pCi} / \mathrm{g}$, respectively-all at U3R-1A.

The distribution and concentration of radionuclides in river sediment during 2010 were similar to those of previous years (data table 5-19).

Concentrations of all isotopes generally were higher in streams than in the river. As indicated in the earlier discussion of cesium-137, this is to be expected.
Differences observed when these data are compared to those of previous years probably are attributable to the effects of resuspension and deposition, which occur constantly in sediment media.

\section{Grassy Vegetation Description of Surveillance Program}

The radiological program for grassy vegetation is designed to collect and analyze samples from onsite and offsite locations to determine radionuclide concentrations. Vegetation samples are obtained to complement soil and sediment samples to determine the environmental accumulation of radionuclides and to help validate SRS dose models. Vegetation can be contaminated externally by the deposition of airborne radioactive contaminants and internally by uptake, from soil or water, by the roots. Bermuda grass is preferred because of its importance as a pasture grass for dairy herds.

Vegetation samples are obtained from

- locations containing soil radionuclide concentrations that are expected to be higher than normal background levels

- locations receiving water that may have been contaminated

- all air sampling locations

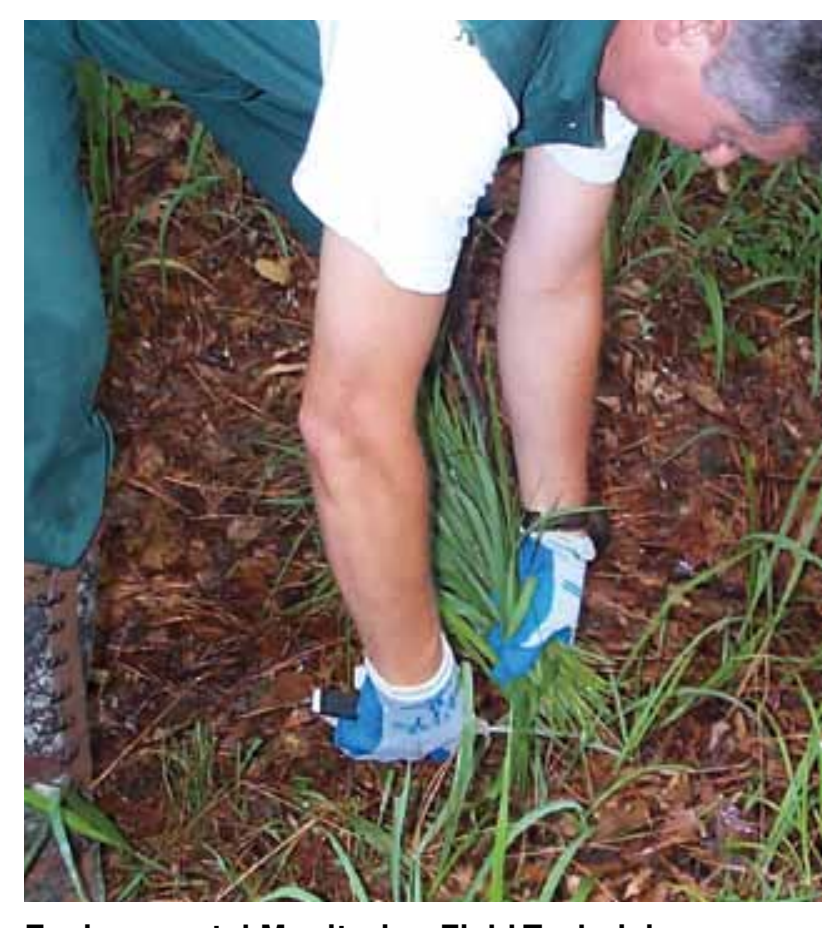

Environmental Monitoring Field Technician Collects Vegetation 
Vegetation samples are analyzed for tritium, gross alpha, gross beta, gamma-emitting radionuclides, strontium-89, 90 , and the actinides.

\section{Surveillance Results Summary}

All vegetation surveillance samples are based on dry weight. Radionuclides in the grassy vegetation samples collected during 2010 were detected in all 17 locations (one onsite, 11 at the perimeter, and four offsite), as follows:

- tritium at six locations (one onsite, five perimeter)

- $\quad$ cesium-137 at four locations (perimeter)

- $\quad$ strontium-89,90 at all 17 locations

- uranium-234 at 13 locations (10 perimeter and three offsite)

- uranium-235 at two locations (perimeter)

- uranium-238 at all 17 locations

- $\quad$ plutonium-238 at 12 locations (nine perimeter and three offsite)

- $\quad$ plutonium-239 at one location (perimeter)

- neptunium-237 at 10 locations (one onsite, five perimeter, and four offsite)

- technetium-99 at all 17 locations

- $\quad$ gross beta at all 17 locations

Overall results show a slight increase in radionuclide concentrations from the past several years, but remain consistent with historical results (data table 5-20).

\section{Savannah River Swamp Surveys Description of Surveillance Program}

The Creek Plantation, a privately owned land area located along the Savannah River, borders part of the southern boundary of SRS. In the 1960s, an area of the Savannah River Swamp on Creek Plantationspecifically, the area between Steel Creek Landing and Little Hell Landing — was contaminated by SRS operations. During high river levels, water from Steel Creek flowed along the lowlands comprising the swamp, resulting in the deposition of radioactive material. SRS studies estimated that a total of approximately $25 \mathrm{Ci}$ of cesium-137 and $1 \mathrm{Ci}$ of cobalt- 60 were deposited in the swamp.

Comprehensive and cursory surveys of the swamp have been conducted periodically since 1974 . These surveys measure radioactivity levels to determine changes in the amount and/or distribution of radioactivity in the swamp. A series of 10 sampling trails - ranging from 240 to 3,200 feet in length-was established through the swamp. Fifty-four monitoring locations were designated on the trails to allow for continued monitoring at a consistent set of locations [Fledderman, 2007].

The 2010 survey was designated as a cursory survey, requiring limited media sampling and analysis. Cursory surveys provide assurance that conditions observed during the more detailed comprehensive surveys have not changed significantly. A comprehensive survey (requiring extensive media sampling and analyses) was conducted in 2007 and is planned again for 2012.

\section{Surveillance Results Summary}

As anticipated, based on source term information and historical survey results, cesium-137 was the primary manmade radionuclide detected in the 2010 survey. Cesium-137 was detected in all 40 soil samples while no cobalt-60 was detected in any of these samples. Cesium-137 concentrations varied from a minimum of $0.21 \mathrm{pCi} / \mathrm{g}$ to a maximum of $60.4 \mathrm{pCi} / \mathrm{g}$. These levels are comparable with those from previous surveys (data table 5-21). The highest concentrations occurred on trails 1 , 2, 4, and 5 (figure 5-9), and concentrations generally decreased with depth. Stronium-89,90 was detected in 23 of the 40 soil samples. The activity ranged from 61.1 $\mathrm{pCi} / \mathrm{kG}$ to $1,290 \mathrm{pCi} / \mathrm{kG}$.

Cesium-137 was detected in seven of the 10 vegetation samples while no cobalt-60 was detected in any of these samples. Detectable concentrations varied from a minimum of $0.62 \mathrm{pCi} / \mathrm{g}$ to a maximum of $10.9 \mathrm{pCi} / \mathrm{g}$. These levels are comparable to results of previous surveys (data table 5-21). Higher concentrations generally were observed on trails 1 and 6 (figure 5-10). Strontium-89,90 was detected in all 10 vegetation samples. The activity ranged from $88.6 \mathrm{pCi} / \mathrm{kG}$ to 1,080 $\mathrm{pCi} / \mathrm{kG}$.

TLD sets were placed at 54 monitoring sites in the swamp during 2010 to determine ambient gamma exposure rates, and all were retrieved. The exposure time varied from 64 to 69 days. The gamma exposure rates ranged from 0.19 to $0.55 \mathrm{mrem} / \mathrm{day}$, which is consistent with the ranges observed historically (data table 5-22). The highest exposure rates were measured on trails 1, 4, 5, and 9 (figure 5-11). This follows trends observed in previous surveys and in the soil results.

\section{Nonradiological Surveillance Air}

SRS does not conduct onsite surveillance for nonradiological ambient air quality. However, to ensure compliance with SCDHEC air quality regulations and standards, SRNL conducted air dispersion modeling for all site sources of criteria pollutants and toxic 


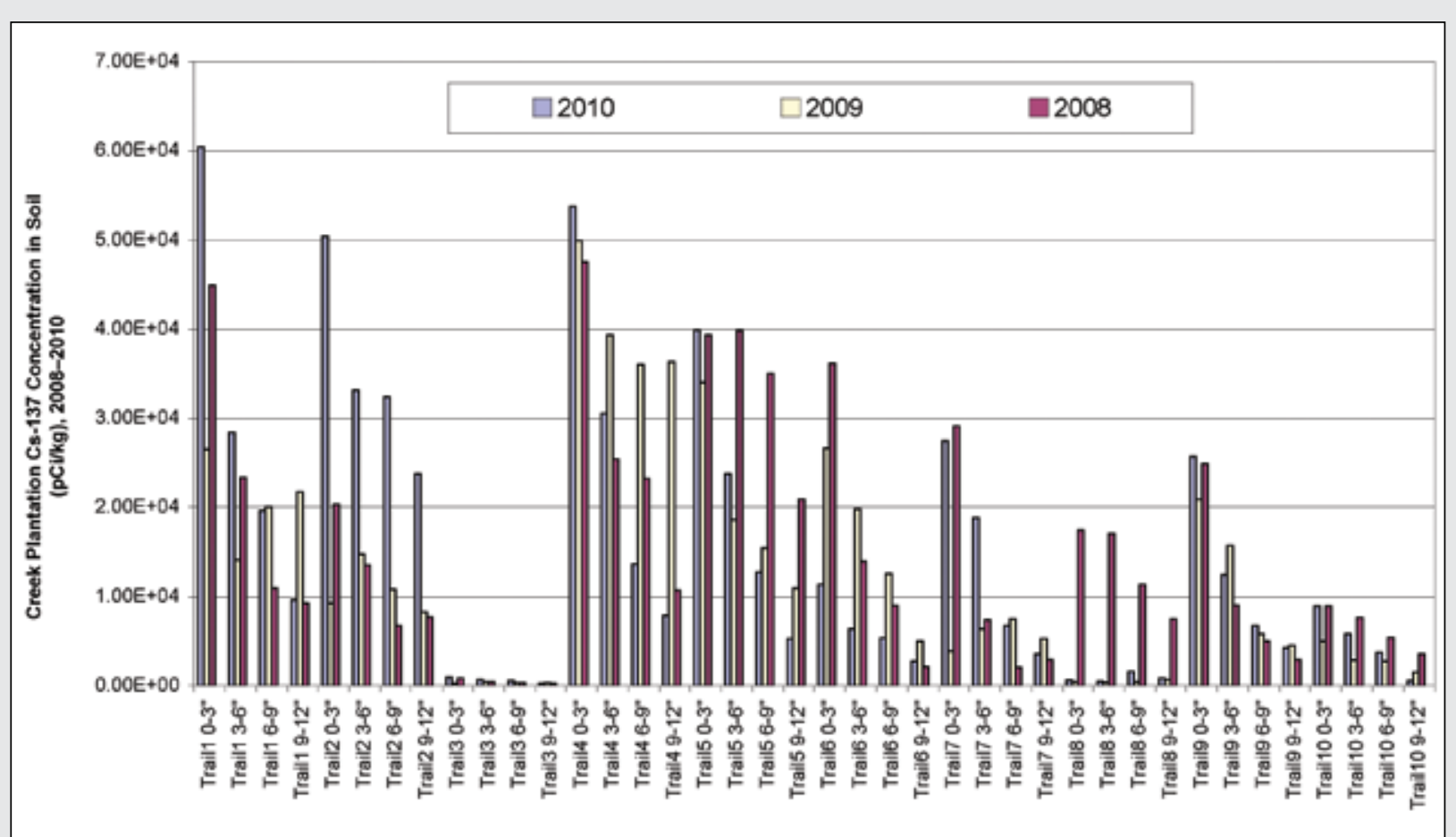

Figure 5-9 Three-Year Trend Chart of Cesium-137 Concentrations in Soil (pCi/kg)

air pollutants in 2010. This modeling indicated that all SRS sources were in compliance with air quality regulations and standards. Since that time, additional modeling conducted for new sources of criteria pollutants and toxic air pollutants has demonstrated continued compliance by the site with current applicable regulations and standards. The states of South Carolina and Georgia continue to monitor ambient air quality near the site as part of a network associated with the federal Clean Air Act.

SRNL sponsors a monitoring and collection station in support of the National Mercury Deposition Network of the National Atmospheric Deposition Program (NADP). This network provides data on the geographic distributions and trends of mercury in precipitation. It is the only network providing a long-term record of mercury concentrations in North American precipitation. All monitoring sites follow standard procedures and have uniform precipitation collectors and gauges. In 2009 (the last year for which data is available), the SRNL monitoring station (SC03) was one of 109 sites that satisfied NADP completeness criteria for national mapping of total mercury concentration and wet deposition. Data from this station indicated that the average (volume-weighted) concentration of total mercury in precipitation in 2009 was $8.4 \mathrm{ng} / \mathrm{L}$, and the wet deposition rate was $10.0 \mu \mathrm{g} / \mathrm{m}^{2}$. Data from 2010 will not be available until the fall of 2011. Additional information on this network is accessible via the following link: http://nadp.sws.uiuc.edu/mdn/.

\section{Surface Water}

SRS streams and the Savannah River are classified by SCDHEC as "Freshwaters," which are defined as surface water suitable for

- $\quad$ primary and secondary contact recreation and as a drinking water source after conventional treatment in accordance with SCDHEC requirements

- fishing and survival/propagation of a balanced indigenous aquatic community of fauna and flora

- industrial and agricultural uses

Appendix A (“Applicable Guidelines, Standards, and Regulations") of this report provides some of the specific standards used in water quality surveillance, but because not all the standards are quantifiable, they are not tracked at SRS.

\section{Surveillance Results Summary}

Water quality parameters were measured at all 16 sampling locations in site streams and along the Savannah River during 2010, and metals were detected in at least one sample at each location. No samples had detectable pesticides/herbicides. These results continue 


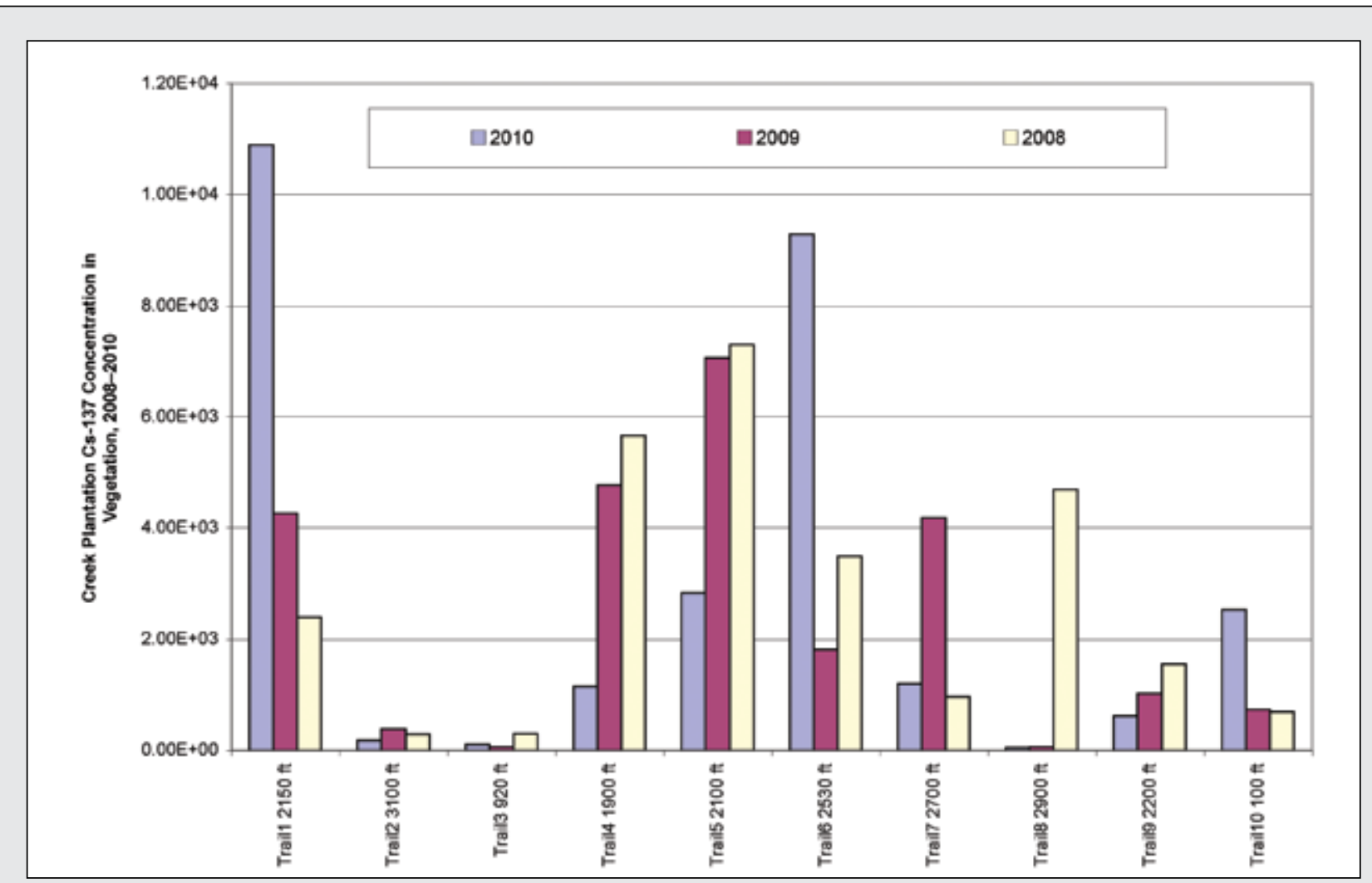

Figure 5-10 Three-Year Trend Chart of Cesium-137 Concentrations in Vegetation ( $\mathrm{pCi} / \mathrm{kg})$

to indicate that SRS discharges are not significantly affecting the water quality of onsite streams or the river (data table 5-23).

\section{Drinking Water}

Most of the drinking water at SRS is supplied by three systems that have treatment plants in A Area, D Area, and $\mathrm{K}$ Area. The site also has 14 small drinking water facilities, each of which serves populations of fewer than 25 persons.

\section{Surveillance Results Summary}

All samples collected from SRS drinking water systems during 2010 were in compliance with SCDHEC and EPA water quality standards. Additional information is provided in the Safe Drinking Water Act section of chapter 3, "Environmental Compliance."

\section{Sediment}

The site's nonradiological sediment surveillance program provides a method to determine the deposition and accumulation of nonradiological contaminants in stream systems. Sample preparation prior to analysis was changed in 2007 from an extraction (toxicity characteristic leaching procedure) to a total sample digestion.

\section{Surveillance Results Summary}

In 2010 , as in the previous 5 years, no pesticides or herbicides were found to be above the quantitation limits in sediment samples. Metals analysis results for 2010 also were comparable to those of the previous 5 years (data table 5-24).

\section{Fish}

Environmental Monitoring personnel analyze the flesh of fish caught from the Savannah and Edisto Rivers to determine concentrations of mercury in the fish. In 2008, the addition of metals (arsenic, cadmium, manganese, and antimony) to the analytical suite was completed. The fish analyzed represent the most common edible species of fish in the CSRA (freshwater) and at the mouth of the Savannah River (saltwater).

\section{Surveillance Results Summary}

Mercury analyses were performed in 2010 on 466 fish from the Savannah River and 45 from the Edisto River at West Bank Landing. Concentrations of mercury 
generally were slightly lower than those observed in 2009 (data table 5-25). The highest concentrations were found in the Savannah River - in bass at the Upper Three Runs Creek Mouth $(1.427 \mu \mathrm{g} / \mathrm{g})$, in catfish at Steel Creek Mouth $(0.446 \mu \mathrm{g} / \mathrm{g})$, and in bream at the Upper Three Runs Creek Mouth $(0.849 \mu \mathrm{g} / \mathrm{g})$. The highest concentrations found at West Bank Landing were 0.750 $\mu \mathrm{g} / \mathrm{g}$ in bass, $0.690 \mu \mathrm{g} / \mathrm{g}$ in bream, and $0.437 \mu \mathrm{g} / \mathrm{g}$ in catfish.

Arsenic and cadmium were below detection levels in all samples. Manganese was detected at all 11 fish sampling locations, with the highest concentration in bream (3.46 $\mu \mathrm{g} / \mathrm{g}$ ) at Stokes Bluff Landing. Antimony also was detected at all locations, with the highest concentration in bream $(1.27 \mu \mathrm{g} / \mathrm{g})$ at the U.S. Highway 301 bridge area (data table 5-26).

\section{River Water Quality Surveys Description of Surveys}

Academy of Natural Sciences (ANS) personnel conducted biological and water quality surveys of the Savannah River from 1951 through 2003, when Environmental Monitoring assumed this responsibility. The surveys were designed to assess potential effects of SRS contaminants and warm-water discharges on the general health of the river and its tributaries. This is accomplished by looking for

- patterns of biological disturbance geographically associated with the site

- patterns of change over seasons or years that indicate improving or deteriorating conditions

In 2010, Environmental Monitoring conducted macroinvertebrate sampling during the spring and fall, and diatom sampling monthly. The diatom slides were sent to ANS for archiving. No adverse biological impacts have been identified in the Savannah River diatom communities.

Macroinvertebrates collected from river traps during 2009 were similar in species diversity to those documented in surveys during the 1990s. An overall decrease in total populations was observed that likely is associated with low flow in the river and incipient drought conditions. No evidence of adverse biological impacts was found in the observed macroinvertebrate communities. Collections from 2010 will be sorted and archived during 2011.

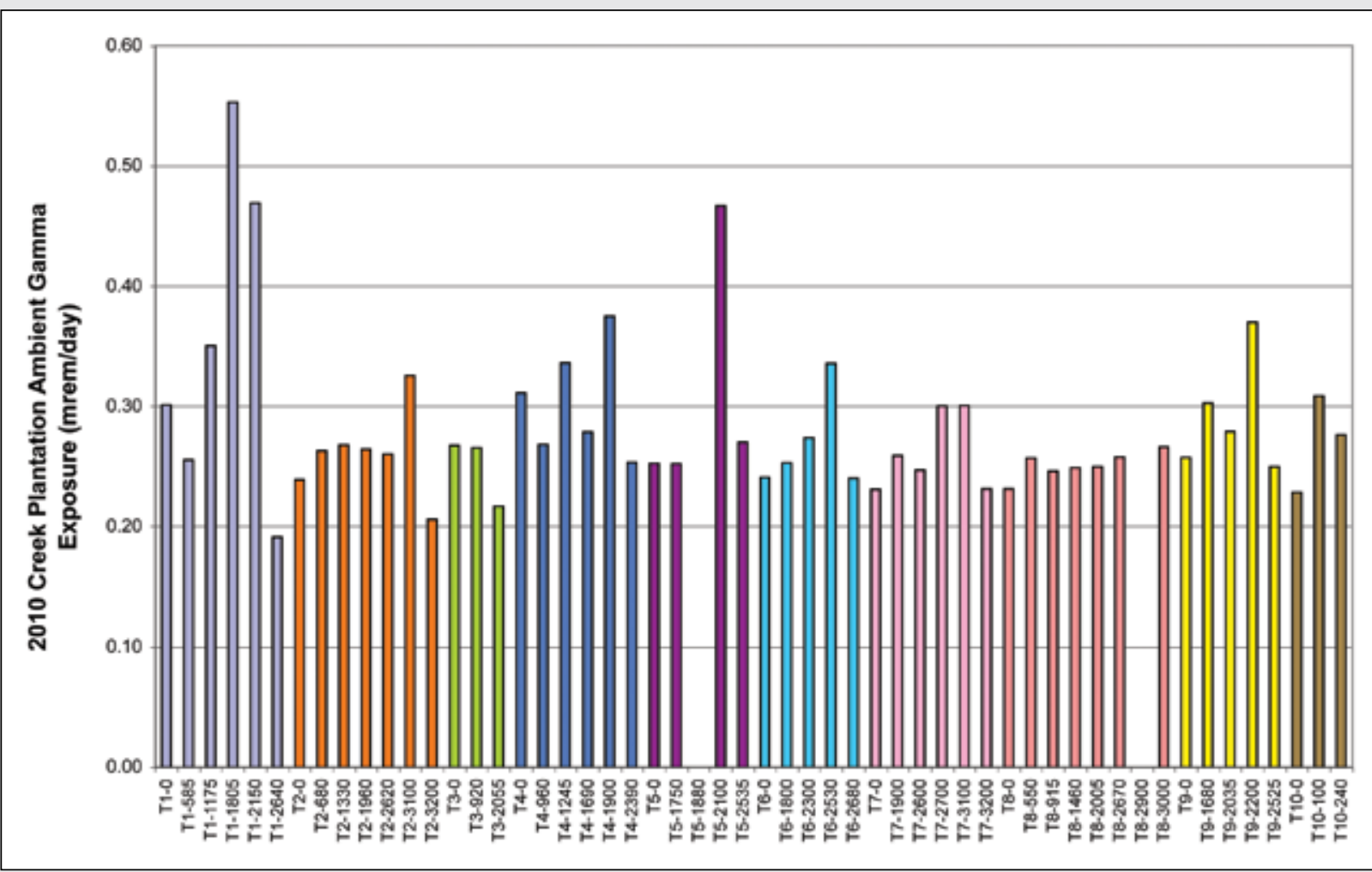

Figure 5-11 Creek Plantation Ambient Gamma Exposure Rates for 10 Transects (T1-0 Means Trail 1, 0 Feet from Savannah River; T2-680 Means Trail 2, 680 Feet from Savannah River, etc.) 



\title{
Radiological Dose Assessments
}

\author{
G. Timothy Jannik, Eduardo B. Farfan, Wendy W. Kuhne, and Kenneth L. Dixon \\ Savannah River National Laboratory
}

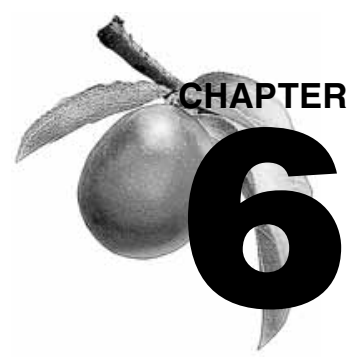

$\mathbf{T}$ his chapter presents the potential doses to offsite individuals and the surrounding population from the 2010 Savannah River Site (SRS) atmospheric and liquid radioactive releases. Also documented are potential doses from special-case exposure scenarios-such as the consumption of deer meat, fish, and goat milk. Unless otherwise noted, the generic term "dose" used in this report includes both the committed effective dose (50-year committed dose) from internal deposition of radionuclides and the effective dose attributable to sources external to the body. Use of the effective dose allows doses from different types of radiation and to different parts of the body to be expressed on the same basis.

Descriptions of the SRS effluent monitoring and environmental surveillance programs discussed in this chapter can be found in chapter 4, "Effluent Monitoring," and chapter 5, "Environmental Surveillance." A complete description of how potential doses are calculated at SRS can be found in the SRS Environmental Dose Assessment Manual [SRS EDAM, 2010].

All dose calculation results are presented in data tables on the CD housed inside the back cover of this report and are referred to in this chapter as "data table 6-X." Tables provided in the chapter are simply referred to as "table 6-X."

\section{Calculating Dose}

Potential offsite doses from SRS effluent releases of radioactive materials (atmospheric and liquid) are calculated for the following scenarios:
- hypothetical maximally exposed individual living at the SRS boundary

- population living within a 50-mile $(80-\mathrm{km})$ radius of SRS (see figure 1 in the "SRS Environmental Data/ Maps" section of the CD accompanying this report)

For compliance purposes, SRS calculates maximallyexposed-individual and collective doses as if the entire 50-mile population consists of adults. For the radioisotopes that contribute the most to SRS's estimated maximum individual doses (i.e., tritium and cesium137), the dose to infants can be approximated as two to three times more than the adult dose. The dose to older children becomes progressively closer to the adult dose [ICRP, 1996].

SRS also uses adult consumption rates for food and drinking water and adult usage parameters to estimate intakes of radionuclides. A detailed review of all applicable land- and water-use parameters was

\section{Dose to the Hypothetical Maximally Exposed Individual}

When calculating radiation doses to the public, SRS uses the concept of the hypothetical maximally exposed individual; however, because of the conservative lifestyle assumptions used in the dose models, no such person is known to exist. The parameters used for the dose calculations are as follows:

For airborne releases - Someone who lives at the SRS boundary (in the sector that has the highest calculated radionuclide concentrations) 365 days per year and consumes milk, meat, and vegetables produced at that location

For liquid releases - Someone who lives downriver of SRS (near River Mile 118.8) 365 days per year, drinks 2 liters of untreated water per day from the Savannah River, consumes $19 \mathrm{~kg}$ (42 pounds) per year of Savannah River fish, and spends time on or near the river

To demonstrate compliance with the DOE Order 5400.5 all-pathway dose standard of 100 mrem per year, SRS conservatively combines the airborne pathway and liquid pathway dose estimates, even though the two doses are calculated for hypothetical individuals residing at different geographic locations. 
conducted in 2010, and the updated values based on this review were used in the 2010 dose calculations. These parameters include local characteristics of food production; river recreational activities; and meat, milk, and vegetable consumption rates, as well as other human usage parameters required in the SRS dosimetry models. In addition, the preferred elemental bioaccumulation and transfer factors to be used in human health exposure calculations at SRS were documented as part of this review [Jannik et al., 2010]. The site-specific input parameters used in the dose calculations are shown in data tables $6-1$ and $6-2$.

For dose calculations, unspecified alpha releases were treated as plutonium-239, and unspecified beta releases were treated as strontium-90. These radionuclides have the highest dose factors of the alpha- and beta-emitters, respectively, that are commonly measured in SRS waste streams.

\section{Dose Calculation Methods}

To calculate annual offsite doses, SRS uses transport and dose models developed for the commercial nuclear industry [NRC, 1977]. The models are described in SRS EDAM [2010].

From 1988 through 2009, SRS used the internal and external dose conversion factors provided in DOE [1988]. For 2010, the internal dose conversion factors were updated to use the latest dose factors provided in International Commission on Radiological Protection (ICRP) Publication 72, Age-dependent Doses to the Members of the Public from Intake of Radionuclides Part 5, Compilation of Ingestion and Inhalation Coefficients [ICRP, 1996]. External dose conversion factors were updated to the latest dose factors from Federal Guidance Report 12, External Exposures to Radionuclides in Air, Water, and Soil [EPA, 1993].

For comparison, the doses estimated for 2009 were recalculated using the updated input parameters and dose conversion factors. The liquid-pathway maximally exposed individual dose would have been about 11 percent less (0.068 mrem vs. $0.077 \mathrm{mrem})$ using the updated factors. Most of this decrease is attributed to the decrease in the plutonium dose factors. The liquidpathway population dose would have been about 35 percent less with the updated factors (1.4 person-rem vs. 2.2 person-rem). This larger percent decrease is mainly attributed to the decrease in the average drinking water consumption rate (updated value is 337 as compared to the previous value of 370 liters per year). For the airborne pathway, the maximally exposed individual dose would have been about 2 percent less using the updated factors ( $0.0411 \mathrm{mrem}$ vs. $0.0419 \mathrm{mrem})$. There was only a minor difference because factors applicable to tritium, which accounts for most of the air-pathway dose, changed very little. The air-pathway population dose would have been about 25 -percent less with the updated factors ( 1.5 person-rem vs. 2.0 person-rem). This difference is mainly attributed to the decrease in the average individual breathing rate from 8,000 to 5,548 cubic meters per year.

\section{Meteorological Database}

To show compliance with DOE environmental orders, potential offsite doses from releases of radioactivity to the atmosphere were calculated with quality-assured meteorological data for A Area, K Area (for combined releases from $\mathrm{C}$ Area, $\mathrm{K}$ Area, and L Area), and $\mathrm{H}$ Area (for combined releases from all other areas). The meteorological databases - for the years 2002-2006, reflecting the most recent 5 -year compilation periodare shown in data table 6-3.

To show compliance with U.S. Environmental Protection Agency (EPA) regulations, only the H Area meteorological database was used in the calculations because the EPA-required dosimetry code (CAP88, Mainframe version 1.0, henceforth referred to simply as CAP88) is limited to a single release location.

\section{Population Database and Distribution}

Collective (population) doses from atmospheric releases are calculated for the population within a 50-mile radius of SRS. Based on the U.S. Census Bureau's 2010 decennial data, the population within a 50-mile radius of the center of SRS is 781,058 - an increase of 9.6 percent over the 2000 population in this area. This translates to an average population density of about 104 people per square mile outside the SRS boundary, with the largest concentration in the Augusta metropolitan area. The population distribution around SRS is provided in data table 6-4.

Some of the collective doses resulting from SRS liquid releases are calculated for the populations served by the City of Savannah Industrial and Domestic Water Supply Plant (Savannah I\&D), near Port Wentworth, Georgia, and by the Beaufort-Jasper Water and Sewer Authority's (BJWSA) Chelsea and Purrysburg Water Treatment Plants, both near Beaufort, South Carolina. According to the treatment plant operators, the population served by the Savannah I\&D facility during 2010 was 26,300 persons, while the population served by the BJWSA Chelsea facility was 77,000 persons and by the BJWSA Purrysburg facility, 58,000 persons. The total population dose resulting from routine SRS liquid releases is the 
sum of four contributing categories: (1) BJSWA water consumers, (2) Savannah I\&D water consumers, (3) consumption of fish and invertebrates of Savannah River origin, and (4) recreational activities on the Savannah River.

\section{River Flow Rate Data}

Savannah River flow rates - recorded at a gauging station near River Mile 118.8 (U.S. Highway 301 bridge) - are based on the measured water elevation. The river flow rates measured at this location from 1954 to 2010 are provided in data table $6-5$. However, these data are not used directly in the SRS dose calculations. Used instead are "effective" flow rates, which are based on (1) the measured annual release of tritium and (2) the annual average tritium concentrations measured at River Mile 118.8 and at the three downriver water treatment plants. The effective river flow rate calculations are shown in data table 6-6. The use of effective flow rates in the dose calculations generally is more conservative than the use of measured flow rates because it accounts for less dilution.

For 2010, the River Mile 118.8 calculated (effective) flow rate of 6,603 cubic feet per second (cfs) was used in the dose calculations. This flow rate was about 4 percent more than the 2009 effective flow rate of $6,324 \mathrm{cfs}$. For comparison, the 2010 annual average flow rate, as measured by the U.S. Geological Survey (USGS), was $9,893 \mathrm{cfs}$. This flow rate is slightly less than the 19542010 mean annual flow rate of $10,222 \mathrm{cfs}$.

The 2010 calculated effective flow rates were 8,030 cfs for the Savannah I\&D facility, $8,898 \mathrm{cfs}$ for the BJWSA Chelsea facility, and 7,113 cfs for the BJWSA Purrysburg facility.

\section{Dose Calculation Results Liquid Pathway Liquid Release Source Terms}

The 2010 radioactive liquid release quantities used as the source term in SRS dose calculations are discussed in chapter 4 and shown by radionuclide in table $6-1$ and by operational area in data table $6-7$. Data table 6-8 provides a 5 -year history of SRS liquid radioactive releases. Tritium accounts for more than 99 percent of the total amount of radioactivity released from the site to the Savannah River. In 2010, a total of 1,285 curies of tritium were released from SRS to the river. In the recent past, the total amount of tritium used in SRS dose calculations was based on the measured tritium concentration at River Mile 118.8. However, the total from this location includes the tritium releases from Georgia Power Company's Vogtle Electric Generating
Plant (VEGP). Since 2006, maximally-exposedindividual doses have been calculated and documented in this report using SRS-only releases.

Data from continuously monitored liquid effluent discharge points are used in conjunction with site seepage basin and Solid Waste Disposal Facility migration release measurements to quantify the total tritium released from SRS. A separate dose calculation is performed (for information only) that includes the total amount of tritium (SRS plus VEGP) measured at River Mile 118.8, which in 2010 was 2,058 curies.

\section{Radionuclide Concentrations in Savannah River Water, Drinking Water, and Fish}

The concentrations of tritium in Savannah River water and cesium-137 in Savannah River fish are measured at several locations along the river for use in dose determinations and model comparisons. The amounts of all other radionuclides released from SRS are so small that they usually cannot be detected in the Savannah River using conventional analytical techniques. Therefore, their concentrations in the river are calculated using the LADTAP $\mathrm{XL}^{\circ}$ code, based on the annual release amounts and on the applicable effective flow rate.

\section{Radionuclide Concentrations in River Water and Treated Drinking Water The measured concentrations of tritium in the Savannah River near River Mile 118.8 and at the Savannah I\&D and BJWSA water treatment facilities are shown in table $6-1$, as are the calculated concentrations for the other released radionuclides. These downriver tritium concentrations include tritium releases from SRS and the neighboring VEGP.}

In 2010, the 12-month average tritium concentration measured in Savannah River water near River Mile 118.8 (349 pCi/L) was 29 percent less the 2009 concentration of $493 \mathrm{pCi} / \mathrm{L}$. This decrease is attributed to fewer curies of tritium released from SRS and VEGP and to the increase in river flow from 2009 to 2010. The 2010 concentrations at the BJSWA Chelsea $(259 \mathrm{pCi} / \mathrm{L})$ and Purrysburg $(324 \mathrm{pCi} / \mathrm{L})$ facilities, and at the Savannah I\&D (287 pCi/L) water treatment plant, were proportionately lower than in 2009, and remained below the EPA drinking water maximum contaminant level (MCL) of 20,000 pCi/L. The drinking water MCL for each radionuclide released from SRS during 2010 is provided in table $6-1$. The table indicates that all individual radionuclide concentrations at the three downriver community drinking water systems, as well as at River Mile 118.8, were below the MCLs. 


\begin{tabular}{|c|c|c|c|c|c|c|}
\hline \multirow[b]{2}{*}{ Nuclide } & \multirow[b]{2}{*}{$\begin{array}{c}\text { Curies } \\
\text { Released }\end{array}$} & \multicolumn{5}{|c|}{ 12-Month Average Concentration ( $\mathrm{pC} / \mathrm{L}$ ) } \\
\hline & & $\begin{array}{c}\text { Below } \\
\text { SRS }\end{array}$ & $\begin{array}{l}\text { BJWSA } \\
\text { Chelseab }^{b}\end{array}$ & $\begin{array}{c}\text { BJWSA } \\
\text { Purrysburg }\end{array}$ & $\begin{array}{c}\text { Savannah } \\
\text { I\&Dc }\end{array}$ & $\begin{array}{l}\text { EPA } \\
\text { MCL }\end{array}$ \\
\hline $\mathrm{H}-3^{(\mathrm{d})}$ & $2.06 \mathrm{E}+03$ & $3.49 \mathrm{E}+02$ & $2.59 \mathrm{E}+02$ & $3.24 \mathrm{E}+02$ & $2.87 \mathrm{E}+02$ & $2.00 \mathrm{E}+04$ \\
\hline Sr-90 & 3.84E-02 & $6.51 \mathrm{E}-03$ & 4.83E-03 & 6.04E-03 & 5.35E-03 & $8.00 \mathrm{E}+00$ \\
\hline Tc-99 & 2.39E-02 & 4.05E-03 & 3.01E-03 & 3.76E-03 & 3.33E-03 & $9.00 \mathrm{E}+02$ \\
\hline I-129 & 2.65E-02 & $4.49 \mathrm{E}-03$ & 3.33E-03 & 4.17E-03 & $3.70 \mathrm{E}-03$ & $1.00 \mathrm{E}+00$ \\
\hline Cs-137 & 4.53E-02 & 1.02E-02 & 7.55E-03 & $9.44 \mathrm{E}-03$ & 8.37E-03 & $2.00 \mathrm{E}+02$ \\
\hline U-234 & 4.09E-04 & 6.94E-05 & 5.15E-05 & $6.44 \mathrm{E}-05$ & 5.70E-05 & $1.03 \mathrm{E}+01$ \\
\hline U-235 & $1.95 \mathrm{E}-05$ & 3.31E-06 & 2.45E-06 & 3.07E-06 & 2.72E-06 & 4.67E-01 \\
\hline U-238 & 3.61E-04 & $6.12 \mathrm{E}-05$ & 4.54E-05 & $5.68 \mathrm{E}-05$ & 5.03E-05 & $1.00 \mathrm{E}+01$ \\
\hline Pu-238 & $2.05 \mathrm{E}-03$ & $3.48 \mathrm{E}-04$ & $2.58 \mathrm{E}-04$ & 3.23E-04 & 2.86E-04 & $1.50 \mathrm{E}+01$ \\
\hline Pu-239 & $1.64 \mathrm{E}-04$ & $2.78 \mathrm{E}-05$ & 2.06E-05 & $2.58 \mathrm{E}-05$ & $2.29 \mathrm{E}-05$ & $1.50 \mathrm{E}+01$ \\
\hline Am-241 & 7.34E-05 & 1.24E-05 & $9.24 \mathrm{E}-06$ & 1.16E-05 & 1.02E-05 & $1.50 \mathrm{E}+01$ \\
\hline $\mathrm{Cm}-244$ & 1.76E-05 & $2.98 \mathrm{E}-06$ & 2.21E-06 & 2.77E-06 & $2.45 \mathrm{E}-06$ & $1.50 \mathrm{E}+01$ \\
\hline Alpha & 7.15E-02 & $1.21 \mathrm{E}-02$ & $9.00 \mathrm{E}-03$ & 1.13E-02 & 9.97E-03 & $1.50 \mathrm{E}+01$ \\
\hline Beta & $1.26 \mathrm{E}-01$ & $2.14 \mathrm{E}-02$ & 1.59E-02 & $1.98 \mathrm{E}-02$ & 1.76E-02 & $8.00 \mathrm{E}+00$ \\
\hline
\end{tabular}

${ }^{a}$ Near Savannah River Mile 118.8, downriver of SRS at the U.S. Highway 301 bridge

${ }^{\mathrm{b}}$ Beaufort-Jasper, South Carolina, drinking water

${ }^{\mathrm{c}}$ Port Wentworth, Georgia, drinking water

${ }^{d}$ The tritium concentrations and source term are based on actual measurements of the Savannah River water at the various locations. They include contributions from the VEGP.

All other radionuclide concentrations are calculated based on the measured releases and the effective river flow rate.

${ }^{e} \mathrm{MCLs}$ for uranium based on radioisotope-specific activity $X 30 \mu \mathrm{g} / \mathrm{L} X$ isotopic abundance

Because more than one radionuclide is released from SRS, the sum of the fractions of the reported concentration of each radionuclide divided by its corresponding MCL must not exceed 1.0. As shown in data table 6-9, the sums of the fractions were 0.0195 at the BJSWA Chelsea facility, 0.0244 at the BJSWA Purrysburg facility, and 0.0217 at the Savannah I\&D facility. These are below the 1.0 sum-of-the-fractions requirement.

For 2010, the sum of the fractions at the River Mile 118.8 location was 0.0263 . This is provided only for comparison because River Mile 118.8 is not a community drinking water system location.

Radionuclide Concentrations in River Fish At SRS, an important dose pathway for the maximally exposed individual is from the consumption of fish. Fish exhibit a high degree of bioaccumulation for certain elements. For the element cesium (including radioactive isotopes of cesium), the bioaccumulation factor for Savannah River fish is 3,000. That is, the concentration of cesium found in fish flesh is about
3,000 times the concentration of cesium found in the water in which the fish live [Carlton et al., 1994].

Because of this high bioaccumulation factor, cesium137 is detected more easily in fish flesh than in river water. Therefore, the fish pathway dose from cesium-137 normally is based directly on the radioanalysis of the fish collected near Savannah River Mile 118.8, which is the assumed location of the hypothetical maximally exposed individual. The amount of cesium-137 estimated to have been released from SRS during the year is adjusted to equate to the concentration measured in fish, as shown in data table $6-10$. For 2010, the adjusted cesium-137 source term (based on fish concentrations) was $0.060 \mathrm{Ci}$, as compared to the amount measured in effluent releases of $0.045 \mathrm{Ci}$.

\section{Dose to the Maximally Exposed Individual}

As shown in table 6-2, the highest potential dose to the maximally exposed individual from SRS liquid releases in 2010 was estimated at $0.06 \mathrm{mrem}(0.0006$ $\mathrm{mSv})$. This dose is 0.06 percent of the DOE Order 5400.5 ("Radiation Protection of the Public and the 
Environment") 100-mrem all-pathway dose standard for annual exposure. The 2010 dose is 25 -percent less than the 2009 dose of 0.08 mrem $(0.0008 \mathrm{mSv})$. This reduction is attributed primarily to decreases in tritium and cesium-137 releases from SRS (data table 6-8). A 5 -year history of SRS doses is provided in data table 6-11.

Approximately 48 percent of the 2010 dose to the maximally exposed individual resulted from the ingestion of cesium-137, mainly from the consumption of fish. About 18 percent of the dose resulted from the ingestion of tritium (mainly via drinking water) and about 25 percent was attributed to the ingestion of unspecified alpha emitters. Every other radionuclide contributed less than 5 percent to the dose. The doses by radionuclide and pathway are provided in data table 6-12

Using the 2010 total Savannah River tritium source term (which includes SRS and VEGP releases) of 2,058 curies, the maximally-exposed-individual dose was calculated to be $0.07 \mathrm{mrem}(0.0007 \mathrm{mSv})$. This dose, which is provided here for information only, is about 22 percent less than the 2009 dose of 0.09 mrem $(0.0009$ $\mathrm{mSv})$.

\section{Drinking Water Pathway Dose}

Persons downriver of SRS may receive a radiation dose by consuming drinking water that contains radioactivity as a result of liquid releases from the site. As shown in data tables 6-13 and 6-14, tritium in downriver drinking water represented the majority of the dose (about 46 percent) received by customers of the three downriver water treatment plants. Unspecified alpha-emitters accounted for about 36 percent, unspecified betaemitters contributed 7 percent, and iodine- 129 releases, about 6 percent. All other individual radionuclides contributed 2 percent or less to the dose.

Based on SRS-only releases, the maximum potential drinking water dose during 2010 was determined to be $0.02 \mathrm{mrem}(0.0002 \mathrm{mSv})$, which was about the same as the 2009 dose (data table 6-11). As shown in table $6-2$, the maximum dose of $0.02 \mathrm{mrem}(0.0002 \mathrm{mSv})$ is 0.5 percent of the DOE standard of 4 mrem per year for public drinking water supplies.

Using the SRS-plus-VEGP total tritium source term of 2,058 curies, the maximum drinking water dose was calculated to be $0.03 \mathrm{mrem}(0.0003 \mathrm{mSv})$ in 2010 .

\section{Collective (Population) Dose}

The collective drinking water consumption dose is calculated for the discrete population groups served by the BJWSA and Savannah I\&D water treatment plants. The collective dose from other pathways is calculated for a diffuse population that makes use of the Savannah River; however, this population cannot be described as being in a specific geographical location.

As shown in data table 6-15, the collective dose from SRS liquid releases was estimated at 1.9 person-rem ( 0.019 person-Sv) in 2010 . This is about 14 percent less than the 2009 collective dose of 2.2 person-rem $(0.022$ person-Sv). Again, this decrease is attributed mainly to decreases in tritium and cesium-137 releases from SRS (data table 6-8).

Using the SRS-plus-VEGP total tritium source term of

Table 6-2 Potential Dose to the Maximally Exposed Individual from SRS Liquid Releases in 2010

\begin{tabular}{|lccc|}
\hline & $\begin{array}{c}\text { Committed } \\
\text { Dose (mrem) }\end{array}$ & $\begin{array}{c}\text { Applicable } \\
\text { Standard (mrem) }\end{array}$ & $\begin{array}{c}\text { Percent } \\
\text { of Standard (\%) }\end{array}$ \\
\hline $\begin{array}{l}\text { Maximally Exposed Individual } \\
\text { Near Site Boundary } \\
\text { (all liquid pathways) }\end{array}$ & 0.06 & $100^{\mathrm{a}}$ & 0.06 \\
$\begin{array}{l}\text { At BJSWA Chelsea } \\
\text { (public water supply only) }\end{array}$ & 0.02 & $4^{\mathrm{b}}$ & 0.5 \\
$\begin{array}{l}\text { At BJSWA Purrysburg } \\
\text { (public water supply only) }\end{array}$ & 0.02 & $4^{\mathrm{b}}$ & 0.5 \\
$\begin{array}{l}\text { At Savannah I\&D } \\
\text { (public water supply only) }\end{array}$ & 0.02 & $4^{\mathrm{b}}$ & 0.5 \\
\hline
\end{tabular}

a All-pathway dose standard: 100 mrem per year (DOE Order 5400.5)

${ }^{\mathrm{b}}$ Drinking water pathway standard: 4 mrem per year (DOE Order 5400.5) 


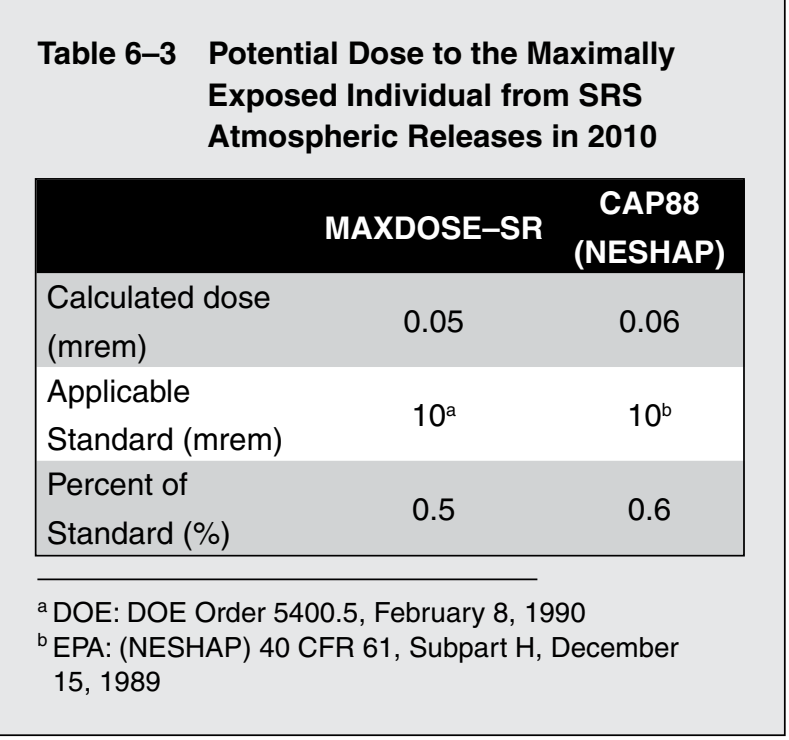

2,058 curies, the collective dose was calculated to be 2.3 person-rem (0.023 person-Sv) in 2010.

\section{Potential Dose from Agricultural Irrigation}

Based on discussions with personnel in the Georgia Department of Natural Resources (GDNR), the South Carolina Department of Health and Environmental Control (SCDHEC), and the U.S. Geological Survey (USGS), there are no known large-scale uses of Savannah River water downstream of SRS for agricultural irrigation purposes. However, the potential for agricultural irrigation does exist, so doses from this pathway are calculated for informational purposes only, but are not included in calculations of the official maximally-exposed-individual or collective doses.

Collective doses from agricultural irrigation were calculated assuming that 1,000 acres of land were devoted to each of the major food types grown in the SRS area (vegetables, milk, and meat). It is assumed that all the food produced on these 1,000-acre parcels is consumed by the population $(781,058)$ within 50 miles of SRS.

As shown in data table $6-16$, a potential dose of 0.1 mrem $(0.001 \mathrm{mSv})$ to the maximally exposed individual and a potential collective dose of 1.5 person-rem $(0.015$ person-Sv) were estimated for this exposure pathway in 2010.

\section{Air Pathway \\ Atmospheric Source Terms}

The 2010 radioactive atmospheric release quantities used as the source term in SRS dose calculations are discussed in chapter 4 and are provided in data table
6-17. Estimates of unmonitored diffuse and fugitive sources were included in the atmospheric source term, as required, for demonstrating compliance with National Emission Standards for Hazardous Air Pollutants (NESHAP) regulations. A 5-year history of SRS atmospheric releases is provided in data table 6-18.

\section{Atmospheric Concentrations}

Calculated radionuclide concentrations instead of measured concentrations are used for dose determinations. This is because most radionuclides released from SRS cannot be measured (using conventional analytical methods) in the air samples collected at the site perimeter and offsite locations. However, the concentrations of tritium oxide at the site perimeter locations usually can be measuredand are compared with calculated concentrations as a verification of the dose models in data table 6-19.

\section{Dose to the Maximally Exposed Individual}

The 2010 estimated dose from atmospheric releases to the maximally exposed individual (calculated with MAXDOSE-SR) was 0.05 mrem (0.0005 $\mathrm{mSv}$ ), which is 0.5 percent of the DOE Order 5400.5 air pathway standard of 10 mrem per year. Table 6-3 compares the maximally-exposed-individual dose with the DOE standard. The 2010 dose was 25 percent more than the 2009 dose of 0.04 mrem $(0.0004 \mathrm{mSv})$. This increase is attributed primarily to increases in the estimated diffuse and fugitive releases of (1) plutonium isotopes from the Burial Ground Transuranic (TRU) Facility and (2) tritium and low levels of various other isotopes from the $P$ Reactor Disassembly Basin Decommissioning Project (evaporation of P Reactor Disassembly Basin water during 2010). A 5-year history of SRS doses is provided in data table $6-11$.

The 2010 atmospheric doses by radionuclide and pathway are provided in data table 6-20. Tritium oxide releases accounted for about 82 percent of the dose to the maximally exposed individual, and plutonium-238 releases accounted for about 8 percent of the dose. No other individual radionuclide accounted for more than 5 percent of the maximallyexposed-individual dose. The major pathways contributing to the maximally-exposed-individual dose from atmospheric releases were inhalation (47 percent), vegetation consumption (32 percent), and cow milk consumption (17 percent). As shown in data table 6-21 and in data map figure 16, the due north sector of the site was the location of the highest dose to the maximally exposed individual. 
Because of the potential in the SRS area for exposure to goat milk, additional calculations of the dose to the maximally exposed individual were performed substituting goat milk for the customary cow milk pathway. As shown in data table 6-22, the potential dose to the maximally exposed individual using the goat milk pathway instead of the cow milk pathway also was estimated at about $0.06 \mathrm{mrem}(0.0006 \mathrm{mSv})$.

\section{Collective (Population) Dose}

The air-pathway collective dose is calculated for the entire 781,058 population living within 50 miles of SRS. The population distribution around SRS is provided in data table 6-4. In 2010, the airborne-pathway collective dose (calculated with POPDOSE-SR) was estimated at 1.9 person-rem (0.019 person$\mathrm{Sv}$ )-less than 0.01 percent of the annual collective dose received from natural sources of radiation (about 214,000 person-rem). The 2010 air-pathway collective doses by radionuclide and pathway are provided in data table $6-23$. Tritium oxide releases accounted for about 79 percent of the collective dose. The 2010 collective dose was about 5 percent less than the 2009 collective dose of 2.0 person-rem $(0.020$ person-Sv). This decrease is attributed mainly to the reduction in the assumed breathing rate for the average person from 8,000 to 5,548 cubic meters per year, which offset the 9.6-percent increase in the total population [Jannik et al., 2010].

\section{NESHAP Compliance}

To demonstrate compliance with NESHAP regulations [EPA, 2002a], maximally-exposed-individual and collective doses were calculated using (1) the CAP88 computer code, (2) the 2010 airborne-release source term (data table 6-24), and (3) site-specific input parameters (data table 6-25). Changes to the CAP88 code cannot be made without specific EPA approval. Therefore, changes to the input parameters and dose factors (refer to the Dose Calculation Methods section of this chapter) that were made in 2010 for the MAXDOSE-SR and POPDOSE-SR codes were not incorporated into the CAP88 code.

The CAP88 code estimates a higher dose for tritium oxide than do the MAXDOSE-SR and POPDOSE-SR codes, which are used for demonstrating compliance with DOE environmental orders. Most of the differences occur in the tritium dose estimated from food consumption. The major cause of this difference is the CAP88 code's use of 100-percent equilibrium between tritium in air moisture and tritium in food moisture, whereas the MAXDOSE-SR and POPDOSE-SR codes use 50-percent equilibrium values, as recommended by the Nuclear Regulatory Commission [NRC, 1977]. A site-specific study indicated that the 50-percent value is correct for the atmospheric conditions at SRS [Hamby and Bauer, 1994].

For 2010, the maximally-exposed-individual dose was estimated at $0.06 \mathrm{mrem}(0.0006 \mathrm{mSv})$, which is 0.6 percent of the 10-mrem-per-year EPA standard, as shown in table $6-3$. The 2010 doses by radionuclide are provided in data table $6-26$. Tritium oxide releases accounted for about 88 percent of this dose and plutonium-238 accounted for 9 percent. The 2010 NESHAP compliance dose was about 50 percent more than the 2009 dose of 0.04 mrem $(0.0004 \mathrm{mSv})$. This increase is attributed to the increased tritium and plutonium diffuse and fugitive releases discussed previously.

Because tritium oxide dominates the doses determined using the CAP88 code, other radionuclides (such as iodine-129) are less important - on a percentage-of-dose basis - for the CAP88 doses than for the MAXDOSESR and POPDOSE-SR doses.

For NESHAP, the dose from diffuse and fugitive releases is required to be reported separately. As shown in data table 6-27, the maximally-exposed-individual dose from diffuse and fugitive releases was estimated to be about $0.03 \mathrm{mrem}(0.0003 \mathrm{mSv})$, which accounts for half of the total 2010 maximally-exposed-individual dose calculated using CAP88.

The CAP88-determined collective dose was estimated at 6.5 person-rem ( 0.065 person-Sv). Tritium oxide releases accounted for about 88 percent of this dose.

Comparisons (by pathway and major radionuclides) of the CAP88-determined maximally exposed individual and collective doses with the MAXDOSE-SR and POPDOSE-SR doses are provided in data tables 6-28 and 6-29, respectively.

\section{All-Pathway Dose}

To demonstrate compliance with the DOE Order 5400.5 all-pathway dose standard of $100 \mathrm{mrem}(1.0 \mathrm{mSv})$ per year, SRS conservatively combines the maximallyexposed-individual airborne pathway and liquid pathway dose estimates, even though the two doses are calculated for hypothetical individuals residing at different geographic locations. 


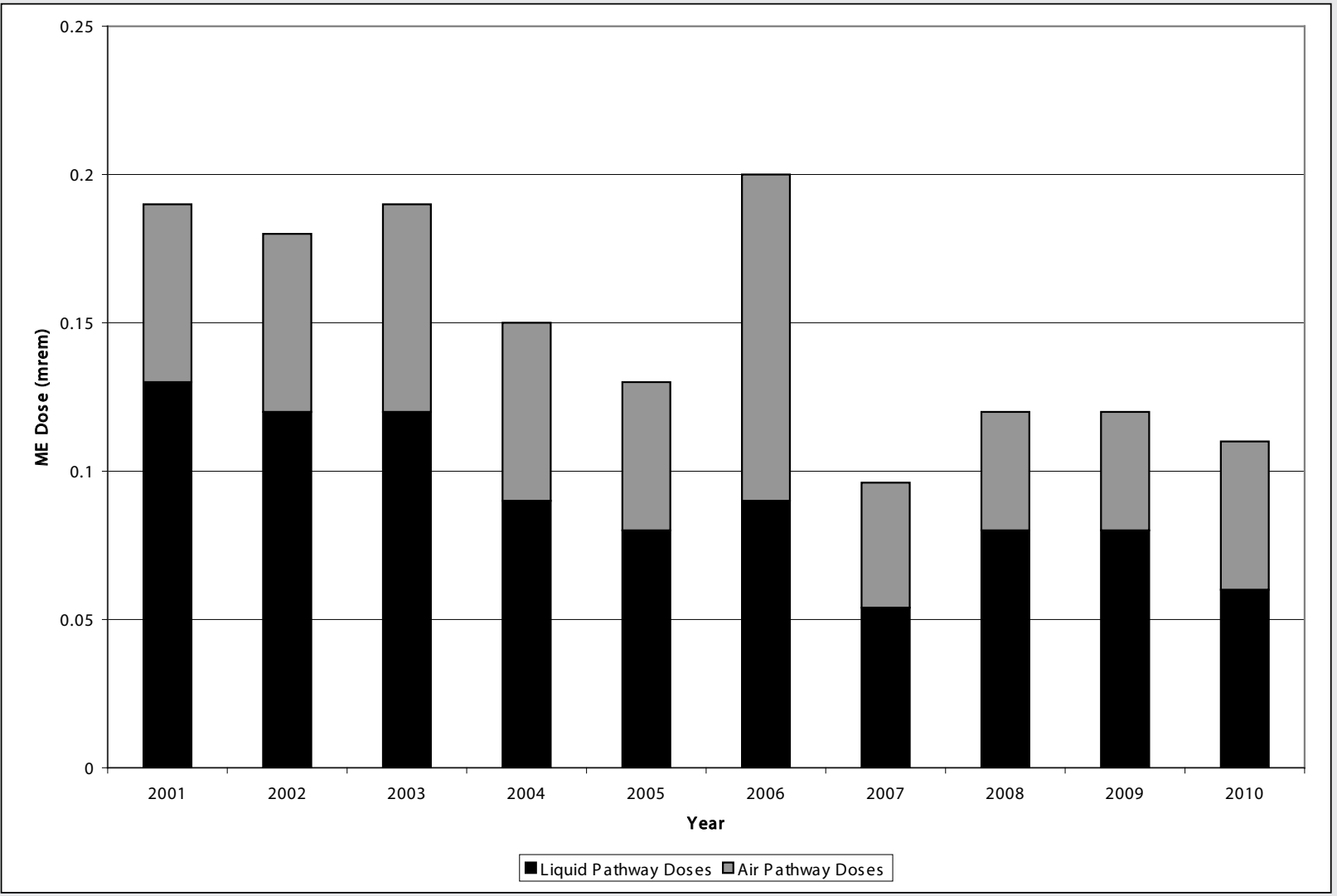

Figure 6-1 Ten-Year History of SRS Maximum Potential All-Pathway Doses

For 2010, the potential maximally-exposed-individual all-pathway dose was $0.11 \mathrm{mrem}(0.0011 \mathrm{mSv})-0.05$ mrem from air pathways plus 0.06 mrem from liquid pathways. The all-pathway dose is 0.11 percent of the 100-mrem-per-year DOE dose standard. The 2010 allpathway dose is about 8 percent less than the 2009 dose of $0.12 \mathrm{mrem}(0.0012 \mathrm{mSv})$.

Figure 6-1 shows a 10-year history of SRS's all-pathway (airborne pathway plus liquid pathway) doses to the maximally exposed individual. The increase in dose in 2006 was due primarily to an increase in the estimated diffuse and fugitive releases from a specific remediation project - the General Separations Area Consolidated Unit (GSACU) — which was completed that year [Mamatey et al., 2007].

\section{Sportsman Dose}

DOE Order 5400.5 specifies radiation dose standards for individual members of the public. The dose standard of 100 mrem per year includes doses a person receives from routine DOE operations through all exposure pathways. Nontypical exposure pathways-not included in the standard calculations of the doses to the maximally exposed individual — are considered and quantified separately. This is because they apply to lowprobability scenarios, such as consumption of fish caught exclusively from the mouths of SRS streams ("creekmouth fish"), or to unique scenarios, such as volunteer deer hunters.

In addition to deer, hog, and fish consumption, the following exposure pathways were considered for an offsite hunter and an offsite fisherman - both on Creek Plantation, a privately owned portion of the Savannah River Swamp, which was contaminated by SRS operations in the 1960s (chapter 5):

- External exposure to contaminated soil

- Incidental ingestion of contaminated soil

- Incidental inhalation of resuspended contaminated soil

\section{Onsite Hunter Dose}

Deer and Hog Consumption Pathway Annual hunts, open to members of the general public, are conducted at SRS to control the site's deer and 
feral hog populations and to reduce animal-vehicle accidents. The estimated dose from the consumption of harvested deer or hog meat is determined for every onsite hunter. During 2010, the maximum dose that could have been received by an actual onsite hunter was estimated at $12.4 \mathrm{mrem}(0.0124 \mathrm{mSv})$, or 12.4 percent of DOE's 100 -mrem all-pathway dose standard (table 6-4). This dose was determined for an actual hunter who in fact harvested eight animals (seven deer and one hog) during the 2010 hunts. The hunter-dose calculation is based on the conservative assumption that this prolific hunter individually consumed the entire edible portion - approximately $245 \mathrm{~kg}$ (540 pounds) — of the animals he harvested from SRS.

\section{Offsite Hunter Dose}

Deer and Hog Consumption Pathway The deer and hog consumption pathway considered was for hypothetical offsite individuals whose entire intake of meat (assumed to be $81 \mathrm{~kg}$ ) during the year was either deer or hog meat. It was assumed that these individuals harvested deer or hogs that had resided at SRS but then moved off site.
Based on these low-probability assumptions and on the measured average concentration of cesium-137 in all deer $(1.09 \mathrm{pCi} / \mathrm{g})$ and hogs $(1.05 \mathrm{pCi} / \mathrm{g})$ harvested from SRS during 2010, the potential maximum doses from this pathway were estimated at $0.37 \mathrm{mrem}$ $(0.0037 \mathrm{mSv})$ for the offsite deer hunter and 0.18 mrem $(0.0018 \mathrm{mSv})$ for the offsite hog hunter. These dose calculations are provided in data table $6-30$.

A background cesium-137 concentration of $1 \mathrm{pCi} / \mathrm{g}$ is subtracted from the onsite average concentrations before calculating the doses. The background concentration is based on previous analyses of deer harvested at least 50 miles from SRS (table 33, SRS Environmental Data for 1994) [SRS Data, 1995].

Savannah River Swamp Hunter Soil Exposure Pathway The potential dose to a recreational hunter exposed to SRS legacy contamination in Savannah River Swamp soil on the privately owned Creek Plantation in 2010 (chapter 5) was estimated using the RESRAD code [Yu et al., 2001]. It was assumed that this recreational sportsman hunted for 120 hours during the year $(8$ hours per day for 15 days) at the location of maximum

Table 6-4 2010 Maximum Potential All-Pathway and Sportsman Doses Compared to the DOE All-Pathway Dose Standard

\begin{tabular}{|lccc|}
\hline & $\begin{array}{c}\text { Committed } \\
\text { Dose (mrem) }\end{array}$ & $\begin{array}{c}\text { Applicable } \\
\text { Standard (mrem) }\end{array}$ & $\begin{array}{c}\text { Percent } \\
\text { of Standard (\%) }\end{array}$ \\
\hline $\begin{array}{l}\text { Maximally-Exposed-Individual Dose } \\
\text { All-Pathway (Liquid Plus Airborne Pathway) }\end{array}$ & 0.11 & 100 & 0.11 \\
Sportsman Dose & 12.4 & 100 & 12.4 \\
Onsite Hunter & 0.22 & 100 & 0.22 \\
Creek-Mouth Fisherman ${ }^{b}$ & & & \\
Savannah River Swamp Hunter & 0.18 & & \\
Offsite Hog Consumption & 0.37 & & \\
Offsite Deer Consumption & 2.90 & 100 & \\
Soil Exposure & & & \\
Total Offsite Deer Hunter Dose & 3.27 & & \\
Savannah River Swamp Fisherman & & & \\
Steel Creek Fish Consumption & 0.22 & 100 & \\
Soil Exposured & 0.28 & & \\
Total Offsite Fisherman Dose & 0.40 & & \\
\hline
\end{tabular}

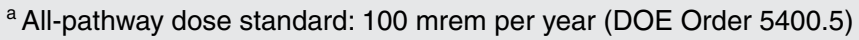

${ }^{\mathrm{b}}$ In 2010, the maximum dose to a hypothetical fisherman resulted from the consumption of bass from the mouth of Steel Creek.

${ }^{\mathrm{c}}$ Includes the dose from a combination of external exposure to and incidental ingestion and inhalation of the worst-case Savannah River Swamp soil

${ }^{\mathrm{d}}$ Includes the dose from a combination of external exposure to and incidental ingestion and inhalation of Savannah River Swamp soil near the mouth of Steel Creek 
radionuclide contamination.

Using the worst-case radionuclide concentrations from the most recent comprehensive surveyconducted in 2007- the potential dose to a hunter from a combination of (1) external exposure to the contaminated soil, (2) incidental ingestion of the soil, and (3) incidental inhalation of resuspended soil was estimated to be 2.9 mrem $(0.029 \mathrm{mSv})$.

As shown in table 6-4, the offsite deer consumption pathway and the Savannah River Swamp hunter soil exposure pathway were conservatively added together to obtain a total offsite hunter dose of $3.27 \mathrm{mrem}$ $(0.0327 \mathrm{mSv})$. This potential dose is 3.27 percent of the DOE 100-mrem all-pathway dose standard.

\section{Offsite Fisherman Dose}

Creek-Mouth Fish Consumption Pathway For 2010, radioanalyses were conducted of three species of fish (panfish, catfish, and bass) taken from the mouths of the five SRS streams. The resulting estimated doses are provided in data table 6-31. To be conservative, all radioanalytical results (even those below the minimum detectable activity) were included in the average radionuclide concentrations. SRS reports the maximum dose from this combination of creek-mouth fish. As shown in table $6-4$, the maximum potential dose from this pathway was estimated at $0.22 \mathrm{mrem}(0.0022 \mathrm{mSv})$ - from the consumption of bass collected at the mouth of Steel Creek This hypothetical dose is based on the low-probability scenario that, during 2010, a fisherman consumed 42 pounds $(19 \mathrm{~kg})$ of bass caught exclusively from the mouth of Steel Creek. About 64 percent of this potential dose was from cesium-137.

Savannah River Swamp Fisherman Soil Exposure Pathway The potential dose to a recreational fisherman exposed to SRS legacy contamination in Savannah River Swamp soil on the privately owned Creek Plantation was estimated using the RESRAD code [Yu et al., 2001]. It was assumed that this recreational sportsman fished on the South Carolina bank of the Savannah River near the mouth of Steel Creek for 250 hours during the year.

Using the radionuclide concentrations measured at this location, the potential dose to a fisherman from a combination of (1) external exposure to the contaminated soil, (2) incidental ingestion of the soil, and (3) incidental inhalation of resuspended soil was estimated to be $0.28 \mathrm{mrem}(0.0028 \mathrm{mSv})$.
As shown in table 6-4, the maximum Steel Creekmouth fish consumption dose $(0.22 \mathrm{mrem})$ and the Savannah River Swamp fisherman soil exposure pathway were conservatively added together to obtain a total offsite creek-mouth fisherman dose of $0.40 \mathrm{mrem}(0.0040 \mathrm{mSv})$. This potential dose is 0.40 percent of the DOE 100-mrem all-pathway dose standard.

\section{Potential Risk from Consumption of SRS Creek-Mouth Fish}

During 1991 and 1992, in response to a U.S. House of Representatives Appropriations Committee request for a plan to evaluate risk to the public from fish collected from the Savannah River, SRS developedin conjunction with EPA, GDNR, and SCDHECthe Westinghouse Savannah River Company/ Environmental Monitoring Section Fish Monitoring Plan. Among the reporting requirements of this plan are (1) assessing radiological risk from the consumption of Savannah River fish and (2) presenting a summary of the results in the annual SRS Environmental Report.

Risk Comparisons For 2010, the maximum potential radiation doses and lifetime risks from the consumption of SRS creek-mouth fish for 1-year, 30-year, and 50-year exposure durations are provided in data table $6-31$, and the maximum values are compared to the radiation risks associated with the DOE Order 5400.5 all-pathway dose standard of $100 \mathrm{mrem}(1.0 \mathrm{mSv})$ per year in table $6-5$. The potential risks were estimated using the cancer morbidity risk coefficients from Federal Guidance Report No. 13 [EPA, 1999a].

For 2010, the maximum recreational fisherman dose was caused by the consumption of bass collected at the mouth of Steel Creek. Figure 6-2 shows a 10 -year history of the annual potential radiation doses from consumption of Savannah River fish. No apparent trends can be discerned from these data. This is because of large variability in the cesium137 concentrations measured in fish from the same location due to differences in

- the size of the fish collected each year

- their mobility and location within the stream mouth from which they are collected

- the time of year they are collected

- the amount of cesium-137 (and other radionuclides) available in the water and sediments at the SRS stream mouths - caused by annual changes in stream flow rates (turbulence) and water chemistry 


\section{Table 6-5 Potential Lifetime Risks from the Consumption of Savannah River Fish Compared to Dose Standards}

\begin{tabular}{|lcc|}
\hline 2010 Savannah River Fish & $\begin{array}{c}\text { Committed Dose }^{\text {Potential Risk }} \\
\text { (mrem) }\end{array}$ & $\begin{array}{c}\text { (unitless) } \\
\text { 1-Year Exposure }\end{array}$ \\
30-Year Exposure & 0.22 & $4.5 \mathrm{E}-07$ \\
50-Year Exposure & 6.60 & $4.6 \mathrm{E}-06$ \\
Dose Standard & 11.00 & $7.6 \mathrm{E}-06$ \\
100-Mrem/Year All Pathway & & $7.3 \mathrm{E}-05$ \\
1-Year Exposure & & $2.2 \mathrm{E}-03$ \\
30-Year Exposure & 100 & $3.7 \mathrm{E}-03$ \\
$50-$ Year Exposure & 3,000 & \\
\hline
\end{tabular}

${ }^{a}$ All radiological risk factors are based on observed and documented health effects to actual people who have received high doses (more than 10,000 mrem) of radiation, such as the Japanese atomic bomb survivors. Radiological risks at low doses (less than $10,000 \mathrm{mrem}$ ) are theoretical and are estimated by extrapolating the observed health effects at high doses to the low-dose region by using a linear, no-threshold model. However, cancer and other health effects have not been observed consistently at low radiation doses because the health risks either do not exist or are so low that they are undetectable by current scientific methods.

As indicated in table 6-5, the 50-year maximum potential lifetime risk from consumption of SRS creekmouth fish was 7.6E-06, which is below the 50-year risk (3.7E-03) associated with the 100-mrem-per-year dose standard.

If a potential lifetime risk is calculated to be less than 1.0E-06 (i.e., one additional case of cancer over what would be expected in a group of $1,000,000$ people), then the risk is considered minimal and the corresponding contaminant concentrations are considered negligible. If a calculated risk is more than 1.0E-04 (one additional case of cancer in a population of 10,000), then some form of corrective action or remediation usually is required. However, if a calculated risk falls between $1.0 \mathrm{E}-04$ and $1.0 \mathrm{E}-06$, which is the case with the maximum potential lifetime risks from the consumption of Savannah River fish, then the risk may be deemed acceptable if it is kept as low as reasonably achievable (ALARA), although actions to further reduce this risk can be considered. At SRS, an environmental ALARA program is in place to ensure that the potential risk from site radioactive liquid effluents (and, therefore, from consumption of Savannah River fish) is kept ALARA [SRS EM Plan, 2010].

\section{Release of Material Containing Residual Radioactivity}

No materials containing residual radioactivity were released from SRS during 2010. DOE issued a moratorium in January 2000 prohibiting the release of volume-contaminated metals, and subsequently suspended the release of metals for recycling purposes from DOE radiological areas in July 2000. No volumecontaminated metals or metals for recycling purposes were released from SRS in 2010.

DOE approved an SRS request in 2003 to use supplemental limits for releasing material from the site with no further DOE controls. These supplemental release limits, which are provided in data table 6-32, are dose-based, and are such that if any member of the public received any exposure, it would be less than $1 \mathrm{mrem} /$ year. The supplemental limits include both surface and volume concentration criteria. The surface criteria are very similar to those used in previous years. The volume criteria allow the disposal of potentially volume-contaminated material in SRS's Three Rivers Landfill, an onsite sanitary facility. In 2010, no material was released from the site using the SRS supplemental release limits volume concentration criteria.

These measures ensure that radiological releases of material from SRS are consistent with the requirements of DOE Order 5400.5.

\section{Radiation Dose to Aquatic and Terrestrial Biota}

DOE Order 5400.5 establishes an interim dose standard for protection of native aquatic animals. The 


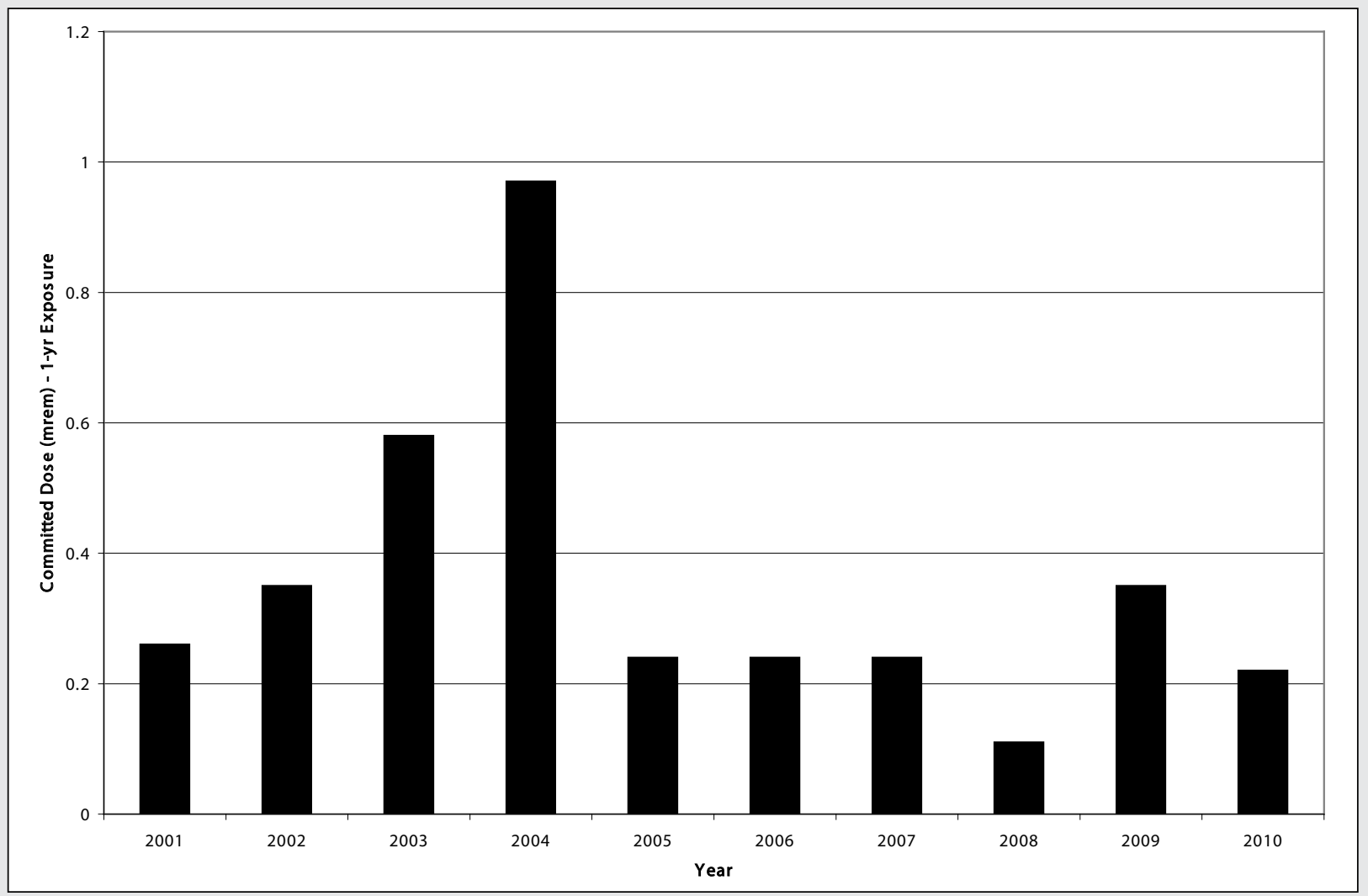

Figure 6-2 Ten-Year History of SRS Creek-Mouth Fisherman's Doses

absorbed dose limit to these organisms is $1.0 \mathrm{rad}$ per day ( 0.01 Gy per day) from exposure to radioactive material in liquid effluents released to natural waterways.

\section{DOE Biota Concentration Guides}

At SRS, the evaluations of biota doses for aquatic and terrestrial systems are performed using the RESRADBiota model (version 1.21), which is based on the DOE standard entitled $A$ Graded Approach for Evaluating Radiation Doses to Aquatic and Terrestrial Biota [DOE, 2002].

The aquatic-systems evaluation includes exposures to primary (herbivores) and secondary (predators) aquatic animals, and the biota concentration guides (BCGs) are based on the 1.0-rad-per-day dose limit. Aquatic plants are not considered. The terrestrial-systems evaluation includes exposures to terrestrial plants and animals, and is based on a 10-rad-per-day dose limit for plants and a 0.1-rad-per-day dose limit for animals. These two terrestrial dose limits-included as part of the RESRAD-Biota model-are not specified in
DOE Order 5400.5. All three biota dose limits are for chronic, long-term exposures to the maximally exposed individual of the applicable species.

For the aquatic-systems evaluation, initial screenings were performed in 2010 using maximum radionuclide concentration data from the 10 SRS Environmental Monitoring stream sampling locations from which collocated water and sediment samples are collected. An exception to this was made for sample location FM-2B (located on Fourmile Branch between F Area and $\mathrm{H}$ Area) because of its historically high cesium and tritium concentration levels. This location was included in the initial screening even though no collocated sediment sample is collected there. The combined water-plus-sediment BCG sum of the fractions was used for the aquatic systems evaluation. A sum of the fractions less than 1.0 indicates the sampling site has passed its initial pathway screening.

For the terrestrial-systems evaluation, initial screenings were performed using concentration data from the five Environmental Monitoring onsite radiological 
soil sampling locations. Only one soil sample per year is collected and analyzed for radioactivity from each location.

For 2010, all terrestrial locations and all but two aquatic locations passed their initial pathway screenings. Failure of the initial screening is not an indication that the biota are at risk at that location; it simply means that additional analysis is needed. The aquatic locations FMA7 and R-1 failed their initial conservative screening but passed the secondary screening by using average concentrations in lieu of the maximum concentrations. All the RESRAD-Biota screening results are provided in data table 6-33. 



\title{
Groundwater
}

\author{
Dan Wells
}

Regulatory Integration \& Environmental Services

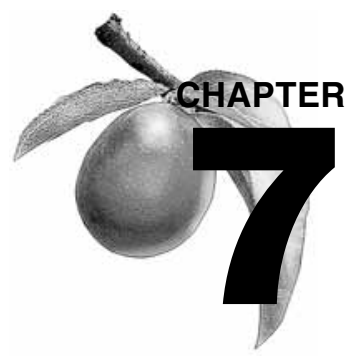

G roundwater protection at the Savannah River Site (SRS) has evolved into a program with the following primary components:

- Protect groundwater by good practices in managing chemicals and work.

- Monitor groundwater to identify areas of contamination.

- Remediate contamination as needed.

- Conserve groundwater.

SRS operations have contaminated groundwater around certain waste disposal facilities. Extensive monitoring and remediation programs are tracking the movement of the contaminated groundwater-and implementing strategies to clean it up. Remediation includes (1) closing waste sites to reduce the migration of contaminants into groundwater and (2) actively treating contaminated water.

No offsite wells have been contaminated by the migration of SRS groundwater.

This chapter describes SRS's groundwater environment and the programs in place for investigating, monitoring, remediating, and using the groundwater.

\section{Groundwater at SRS}

SRS is underlain by sediment of the Atlantic Coastal Plain. The Atlantic Coastal Plain consists of a southeastdipping wedge of unconsolidated sediment that extends from its contact with the Piedmont Province at the Fall Line to the edge of the continental shelf. The sediment ranges from Late Cretaceous to Miocene in age, and comprises layers of sand, muddy sand, and clay with subordinate calcareous sediments. It rests on crystalline and sedimentary basement rock.

Water flows easily through the sandy layers (aquifers) but is retarded by less permeable clayey beds (confining units). Operations during the life of SRS have resulted in contamination migrating into groundwater at various site locations, predominantly in the central areas of the site. The ongoing movement of water into the ground, through the aquifer system, and then into streams and lakes - or even into deeper aquifers - continues to carry contamination along with it, resulting in spreading plumes.

The hydrostratigraphy of SRS has been subject to several classifications. The hydrostratigraphic classification established in Aadland et al., 1995, and in Smits et al., 1996, is used widely at SRS, and is regarded as the current site standard. This system is consistent with the one used by the U.S. Geological Survey (USGS) in regional studies that include the area surrounding SRS [Clarke and West, 1998]. Figure 7-1 indicates the relative position of hydrostratigraphic units, and relates hydrostratigraphic units to corresponding lithologic units at SRS and to the geologic time scale. This chart was modified from Aadland et al., 1995, and Fallaw and Price, 1995.

The hydrostratigraphic units of primary interest beneath SRS are part of the Southeastern Coastal Plain Hydrogeologic Province. Within this sequence of aquifers and confining units are two principal subcategories, the overlying Floridan Aquifer System and the underlying Dublin-Midville Aquifer System. These systems are separated from one another by the Meyers Branch Confining System. In turn, each of the systems is subdivided into two aquifers, which are separated by a confining unit.

In the central to southern portion of SRS, the Floridan Aquifer System is divided into the overlying Upper Three Runs Aquifer and the underlying Gordon Aquifer, which are separated by the Gordon Confining Unit. 


\section{7 - Groundwater}

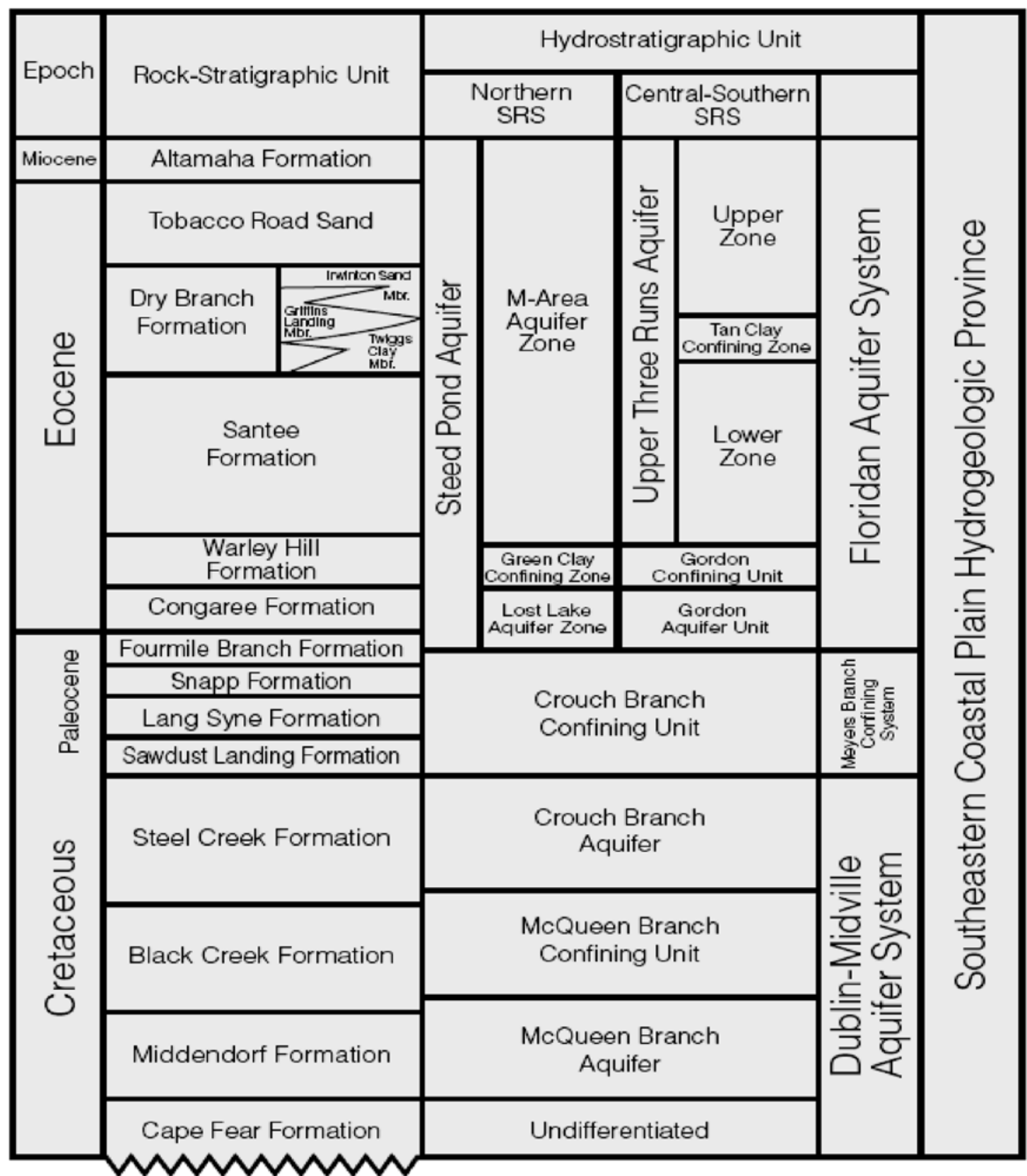

Paleozoic Crystalline

Basement Rock or Triassic

Newark Supergroup

Figure 7-1 Hydrostratigraphic Units at SRS

Piedmont Hydrogeologic Province

Modified from Aadland et al., 1995, and Fallaw and Price, 1995
North of Upper Three Runs Creek, these units are collectively referred to as the Steed Pond Aquifer, in which the Upper Three Runs Aquifer is called the M Area Aquifer zone, the Gordon Aquifer is referred to as the Lost Lake Aquifer zone, and the aquitard that separates them is referred to as the Green Clay confining zone unit, within which the water table usually occurs at SRS; hence, it is referred to informally as the "water table" aquifer. The water table surface can be as deep as 160 feet below ground surface (bgs), but intersects the 
ground surface in seeps along site streams. The top of the Gordon Aquifer typically is encountered at depths of 150-250 feet bgs. The Dublin-Midville Aquifer System is divided into the overlying Crouch Branch Aquifer and the underlying McQueen Branch Aquifer, which are separated by the McQueen Branch Confining Unit. The Crouch Branch Aquifer and McQueen Branch Aquifer are names that originated at SRS [Aadland et al., 1995]. These units are equivalent to the Dublin Aquifer and the Midville Aquifer, which are names originating with the USGS [Clarke and West, 1998]. The top of the Crouch Branch Aquifer typically is encountered at depths of 350-500 feet bgs. The top of the McQueen's Branch Aquifer typically is encountered at depths of 650-750 feet bgs.

Figure 7-2 is a three-dimensional block diagram of the hydrogeologic units at SRS and the generalized groundwater flow patterns within those units. These units are from shallowest to deepest: the Upper Three Runs/Steed Pond Aquifer (or water table aquifer), the Gordon/Lost Lake Aquifer, the Crouch Branch Aquifer, and the McQueen Branch Aquifer. Maps of the potentiometric surfaces of these units are presented in figures 19-22 of the "Environmental Data/Maps - 2010" appendix on the $\mathrm{CD}$ accompanying this report.

Groundwater recharge is a result of rainwater or other precipitation moving downward through the ground to the water table. Upon entering the saturated zone at the water table, water moves predominantly in a horizontal direction toward local discharge zones along the headwaters and midsections of streams, while some of the water moves into successively deeper aquifers. The water lost to successively deeper aquifers also migrates laterally within those units toward the more distant regional discharge zones. These typically are located along major streams, such as Upper Three Runs or Fourmile Branch, or along the Savannah River itself. Groundwater movement within these units is extremely slow when compared to surface water flow rates. Groundwater velocities also are quite different between

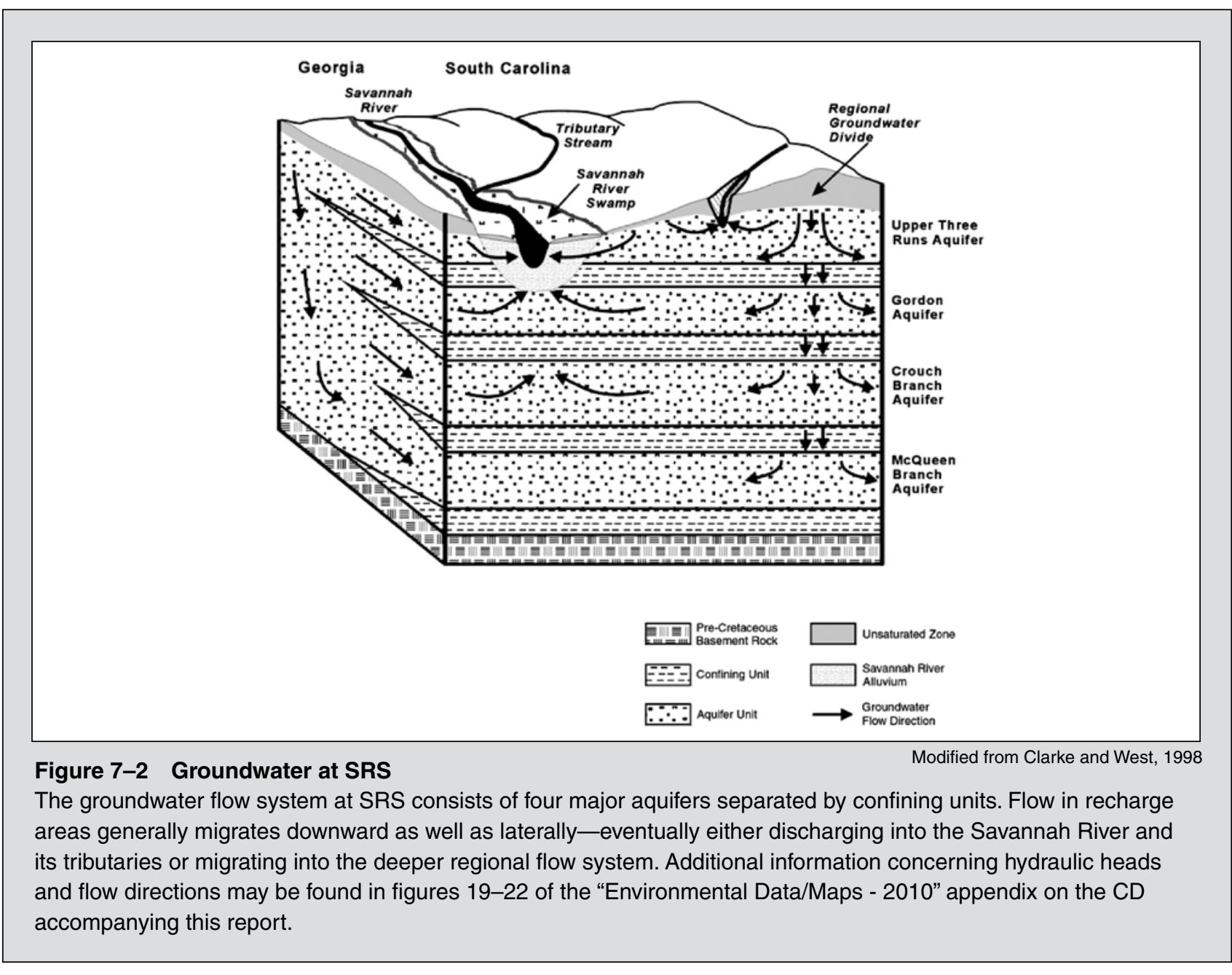


aquitards and aquifers, ranging at SRS from several inches to several feet per year in aquitards and from tens to hundreds of feet per year in aquifers.

Monitoring wells are used extensively at SRS to assess the effects of site activities on groundwater quality. Most of the wells monitor the upper groundwater zone (see figure 7-1), although wells in lower zones are present at the sites with the larger groundwater contamination plumes. Groundwater in some areas contains one or more constituents at or above the levels of the drinking water standards of the U.S. Environmental Protection Agency (EPA). These areas can be seen in figure 18 of the "Environmental Data/Maps - 2010" appendix on the CD accompanying this report. Time-versusconcentration plots for selected wells from contaminated areas also can be found on the $\mathrm{CD}$, which contains all 2010 SRS monitoring data. The coordinates in the data tables can be used with figure 25 in the "Maps" section of the $\mathrm{CD}$ to find the location of individual data points.

\section{Groundwater Protection Program at SRS}

The SRS groundwater protection program is designed to meet federal and state laws/regulations, U.S. Department of Energy (DOE) orders, and site policies/procedures. It contains the following elements:

- investigating site groundwater

- using site groundwater

- protecting site groundwater

- remediating contaminated site groundwater

- monitoring site groundwater

Groundwater monitoring is a key tool used in each of the first four elements, and monitoring results form the basis for evaluations that are reported to site stakeholders.

\section{Investigating SRS Groundwater}

An extensive program is in place at SRS to acquire new data and information on the groundwater system. Investigations include the collection and analysis of data to understand groundwater conditions on both a regional scale (sitewide) and a local scale (individual waste site) at SRS.

Investigative efforts focus on the collection and analysis of data to characterize the groundwater flow system. Characterization efforts at SRS include the following activities:

- collection of geologic core material and performance of seismic profiles to better delineate subsur- face structural features

- installation of wells to allow periodic collection of both water levels and groundwater samples at strategic locations

- development of water table and potentiometric maps to delineate the direction of groundwater movement in the subsurface

- performance of various types of tests to obtain in situ estimates of hydraulic parameters needed to estimate groundwater velocities

Analysis of data on the regional scale is needed to provide a broad understanding of SRS groundwater movement patterns that can be used to better understand the migration of contaminants at the local scale near individual waste units.

Surface water flow characteristics also are defined at SRS on the regional scale and are significant to risk analyses because perennial streams are the receptors of groundwater discharge - some of which contains contaminants from SRS waste units. Because the site boundary does not represent a groundwater boundary, regional studies are helpful in understanding the movement of groundwater both onto the site from the surrounding area and vice versa.

The collection and analysis of data describing subsurface hydrogeologic conditions at or near individual waste units are required to design effective remediation systems. The installation of monitoring wells and piezometers is a traditional investigative method to allow the collection of (1) water levels, which are used to define flow directions, and (2) groundwater samples, which are analyzed to monitor contaminant plume migration within the groundwater flow system. Before permanent wells are sited, a location is usually characterized using direct-push technology, to collect one-time groundwater samples and establish hydrostratigraphic contacts. Permanent wells then are installed using rotosonic, hollow-stem auger or mud rotary drilling techniques. Geophysical data acquired during well installation are used to delineate the subsurface hydrostratigraphy.

Models have been used extensively as analytical tools at SRS for both regional and local investigations. Models have been utilized for a variety of reasons, but primarily to (1) define the regional groundwater movement patterns at SRS and the surrounding areas, (2) enhance the understanding of contaminant migration in the subsurface, (3) support the design of remediation systems, and (4) provide predictive performance 


\section{Sample Scheduling and Collection}

The Geochemical Monitoring group and the Environmental Monitoring Services section schedule groundwater sampling either in response to specific requests from SRS personnel or as part of their ongoing groundwater monitoring program. Approximately 1,100 wells and numerous direct-push holes are sampled each year. Most of the wells are sampled semiannually, but many are sampled only annually. These groundwater samples provide data for reports required by federal and state regulations and for internal reports and research projects. The data are presented in spreadsheets on the attached CD, and fill approximately 186,000 lines.

Nonradioactive constituents that may be analyzed are commonly imposed by permit or work plan approval. These include metals, field parameters, and suites of herbicides, pesticides, volatile organics, and others. Radioactive constituents that may be analyzed include gross alpha and beta measurements, gamma emitters, iodine-129, strontium-90, radium isotopes, uranium isotopes, and other alpha and beta emitters.

Groundwater samples are collected from monitoring wells, generally with either pumps or bailers dedicated to each well to prevent cross-contamination among wells. Occasionally, portable sampling equipment is used; this equipment is decontaminated between wells.

Sampling and shipping equipment and procedures are consistent with EPA, SCDHEC, and U.S. Department of Transportation guidelines. EPA-recommended preservatives and sample-handling techniques are used during sample storage and transportation to both onsite and offsite analytical laboratories. Potentially radioactive samples are screened for total activity prior to shipment to determine appropriate packaging and labeling requirements.

Deviations from scheduled sampling and analysis for 2010 (caused by dry wells, inoperative pumps, etc.) were entered into the site's groundwater database and issued in appropriate reports.

assessments of radioactive waste disposal facilities. At SRS, major groundwater modeling efforts have focused on A Area/M Area, F Area, H Area, the Burial Ground Complex, and several of the reactor areas.

Research on groundwater issues is conducted at SRS to obtain a better understanding of subsurface mechanisms, such as (1) the interaction of contaminants with the porous media matrix and (2) the factors that impact the rate of migration of contaminants within the groundwater flow system. Research to address relevant issues often is conducted through cooperative studies with investigators at various public universities and private companies, while other efforts are conducted exclusively by SRS employees. Published papers resulting from this research may be found at DOE's Office of Scientific and Technical Information website, http://www.osti.gov, and in various technical journals.

\section{Using SRS Groundwater}

SRS derives its own drinking and process water supply from groundwater. SRS domestic and process water systems are supplied from a network of approximately 40 wells in widely scattered locations across the site, of which eight supply the primary drinking water system for the site (figure 14 in the "Environmental Data/Maps - 2010" appendix on the CD accompanying this report). In 1983, SRS began reporting its water usage annually to the South Carolina Water Resources Commission - and later to the South Carolina Department of Health and Environmental Control (SCDHEC). Since that time, the amount of groundwater pumped on site has dropped by more than two thirds - from 10.8 million gallons per day during 1983-1986 to 3.4 million gallons per day in 2010. The majority of this decrease is attributable to the consolidation of site domestic water systems, which was completed in 1997. Thirteen separate systems, each with its own high-capacity supply wells, were consolidated in 1997 into three systems located in A Area, D Area, and K Area. Then, in 2009, these three systems were consolidated into two - in A Area and D Area. This greatly reduced the amount of excess water being pumped to waste. Site facility shutdowns and reductions in population also were contributing factors. An increase from 2.7 million gallons in 2009 to the 3.4-milliongallon figure in 2010 likely was due to a site population increase associated with an influx of American Recovery and Reinvestment Act-associated projects at SRS during that time period.

Treated well water is supplied to the larger site facilities by the A Area and D Area domestic water systems. Each system has wells, a treatment plant, elevated storage tanks, and distribution piping. The wells range in capacity from 200 to 1,500 gallons per minute. The domestic water systems supply site drinking fountains, lunchrooms, restrooms, and showering facilities with 
water meeting state and federal drinking water quality standards. SCDHEC periodically samples the largeand small-system wells for Safe Drinking Water Act contaminants. An unscheduled biannual SCDHEC sanitary survey also is performed.

The process water systems in A Area, F Area, H Area, $\mathrm{K}$ Area, L Area, and S Area meet site demands for boiler feedwater, equipment cooling water, facility washdown water, and makeup water for cooling towers, fire storage tanks, chilled-water-piping loops, and site test facilities. These systems are supplied from dedicated process water wells ranging in capacity from 100 to 1,500 gallons per minute. In K Area, the process water system is supplied from the domestic water wells. At some locations, the process water wells pump to ground-level storage tanks, where the water is treated for corrosion control. At other locations, the wells directly pressurize the process water distribution piping system without supplemental treatment.

\section{Protecting SRS Groundwater}

SRS is committed to protecting the groundwater resource beneath the site. A variety of activities contribute to this goal, including

- construction, waste management, and monitoring efforts to prevent or control sources of groundwater contamination

- monitoring programs (both groundwater and surface water) to detect contamination

- a strong groundwater cleanup program through the site's Area Completion Projects (ACP) organization

Monitoring around known waste disposal sites and operating facilities provides the best means to detect and track groundwater contamination. To detect contamination from as-yet undiscovered sites, SRS depends on a sitewide groundwater monitoring and protection effort - the site Groundwater Surveillance Monitoring Program (GSMP). This program is an upgraded replacement of the site screening program.

One goal of the GSMP is to protect potential offsite receptors from contamination by detecting the contamination in time to apply appropriate corrective actions. SRS is a large site, and most groundwater contamination is located in its central areas. However, the potential for offsite migration exists, and the consequences of such an outcome are serious enough to warrant a comprehensive prevention program.

SRS has evaluated flow in each aquifer and determined where there is potential for flow across the site boundary.
This gives a conservative indication of where offsite contamination might be possible, and allows for a focused monitoring effort in those few areas. Another pathway for existing groundwater contamination to flow off site is by discharge into surface streams and subsequent transport into the Savannah River. SRS monitors site streams for contamination, and has installed wells along several site streams to (1) detect contamination before it enters the streams and (2) assess the contamination's concentration in groundwater.

The SRS groundwater monitoring program gathers information to determine the effects of site operations on groundwater quality. The program is designed to

- assist the site in complying with environmental regulations and DOE directives

- provide data to identify and monitor constituents in the groundwater

- provide data for evaluating new facility locations to ensure suitability for the intended facilities

- $\quad$ support basic and applied research projects

The SRS groundwater monitoring program includes two primary components: (1) waste site monitoring associated with remediation, and (2) groundwater surveillance monitoring.

Monitoring data are evaluated each year to identify unexpected results in any SRS wells that might indicate new or changing groundwater contamination.

Monitoring wells and production wells are properly abandoned when no longer needed. A typical abandonment involves placing a smaller diameter pipe ("tremie pipe") near the bottom of the well and pumping cement grout through it until the well is full. This ensures that grout reaches the bottom of the well. SRS abandoned 139 wells in 2010; additional abandonments are planned for 2011.

\section{Remediating Contaminated SRS Groundwater}

SRS has maintained an environmental remediation effort for many years. ACP personnel manage the cleanup of contaminated groundwater associated with Resource Conservation and Recovery Act (RCRA) hazardous waste management facilities and other non-RCRA contamination sites specified in SRS's Federal Facility Agreement. Their mission is to aggressively manage the inactive waste site and groundwater cleanup program so that

- schedules for environmental agreements are consistently met

- the utilization of financial and technological re- 
sources is continually improved

- the overall risk posed by existing contaminated sites is continually reduced

The ACP strategy revolves around developing an appropriate regulatory framework for each waste site, assessing the degree and extent of contamination, and remediating the contaminated groundwater to its original beneficial use. Remedial action often is applied to the source material overlying contaminated or potentially contaminated groundwater. Soil vapor extraction, (sucking contaminated soil vapor from the subsurface) is widely used at SRS to remove volatile contaminants from the unsaturated zone. The process frequently is enhanced with electrical resistance heating. Concrete slabs are being heated in a few areas to drive out tritium trapped within them.

Remedial technologies being used on the groundwater itself include pump and treat, in situ $\mathrm{pH}$ adjustment, steam injection, phytoremediation, and barrier wall construction. In cases where remediation to background quality is impractical, the intent is to prevent plume migration and exposure and to evaluate alternate methods of risk reduction.

\section{Monitoring SRS Groundwater}

The first priority of the groundwater monitoring program at SRS is to ensure that contamination is not being transported from the site by groundwater flow. Contaminated groundwater at SRS discharges into site streams or the Savannah River. Nowhere have offsite wells been contaminated by groundwater from SRS, and only a few site locations have groundwater with even a remote chance of contaminating such wells.

One of these locations is near A Area/M Area, the site of a large chlorinated solvent plume. This area's groundwater monitoring program uses more than 200 wells, and some of the contaminated wells lie within a half-mile of the site's northwestern boundary. While it is believed that the major component of groundwater flow is not directly toward the site boundary, flow in the area is complex and difficult to predict. For this reason, particular attention is paid to data from wells along the site boundary and from those between A Area/M Area and the nearest population center, Jackson, South Carolina (figure 23 in the "Environmental Data/ Maps - 2010" appendix on the CD accompanying this report). In 2009, one of these wells, MSB91 TB, yielded a trichloroethylene (TCE) result of $1.6 \mathrm{ug} / \mathrm{L}$. In response to this finding, the well was sampled four times during 2010. The May 10 sample contained TCE at $3.92 \mu \mathrm{g} / \mathrm{L}$, but results from the remaining sampling events (in July,
August, and November) were below the detection limit $(0.25 \mu \mathrm{g} / \mathrm{L})$.

Since the early 1990s, considerable effort has been directed at assessing the likelihood of transriver flow from South Carolina to Georgia, and 44 wells have been drilled by the USGS and the Georgia Department of Natural Resources (figure 24 in the "Environmental Data/Maps - 2010" appendix on the CD accompanying this report). Despite the fact that the USGS groundwater model indicates there is no mechanism by which transriver flow could contaminate Georgia wells [Cherry, 2006], SRS continues to maintain the Georgia monitoring wells and sample them annually. In 2010, none of the tritium results exceeded $1,000 \mathrm{pCi} / \mathrm{L}$. Levels this low are consistent with aquifer recharge from rainfall in the SRS area. EPA's maximum contaminant level for tritium is $20,000 \mathrm{pCi} / \mathrm{L}$.

Although contaminated groundwater in most SRS areas does not approach the site boundary, it does have the potential to impact site streams. For this reason-and because of the need to meet the requirements of various environmental regulations - extensive monitoring is conducted around SRS waste sites and operating facilities, regardless of their proximity to the boundary.

All 2010 groundwater monitoring data are included in the "2010 Groundwater Data" table on the CD accompanying this report. It would be impractical to provide maps of all wells; however, Universal Transverse Mercator (UTM) coordinates are provided. These coordinates can be used in conjunction with figure 25 in the "Environmental Data/Maps - 2010" appendix on the $\mathrm{CD}$ to find the approximate locations of the wells. Time-versus-concentrations plots for selected wells and analytes also can be viewed on the CD. The selected wells are from the large plumes at $\mathrm{M}$ Area, at the $\mathrm{F}$ Area and H Area Seepage Basins, and at the Mixed Waste Management Facility. As the plots show, no generalizations can be made about concentration trends sitewide.

Contaminant plumes of particular interest are depicted in a series of maps in the "Environmental Data/Maps - 2010" appendix on the CD. Figures 26-31 depict the trichloroethylene plumes in aquifers beneath A Area and $M$ Area. Figures 32-34 depict the tritium plumes in aquifers beneath E Area, F Area, and H Area. For details about monitoring and conditions at individual sites, one should refer to site-specific documents, such as RCRA corrective action reports or RCRA/Comprehensive Environmental Response, Compensation, and Liability Act and RCRA facility investigation/remedial investigation reports. 



\title{
Quality Assurance
}

\author{
Jay Hutchison \\ Environmental \& Bioassay Laboratory, Environmental Monitoring Laboratory \\ Donald Padgett and Monte Steedley \\ Regulatory Integration \& Environmental Services
}

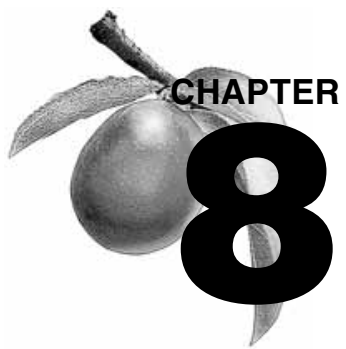

Rick Page

Area Completion Projects

During 2010, responsibilities for administering the Savannah River Site (SRS) environmental quality assurance (QA) program again were divided among three groups-Environmental Monitoring Laboratory (EML), Environmental Monitoring Program (EMP), and Area Completion Projects (ACP).

$\mathbf{S}$ $R S$ conducts an environmental QA program to ensure the integrity of analyses performed by SRS and offsite laboratories and to ensure that quality control $(Q C)$ program requirements are met. The program 's objectives are to ensure that samples are representative of the surrounding environment, and that analytical results are accurate.

\section{Environmental QA Program Integration}

The SRS comprehensive environmental QA program follows the QA requirements defined in the site's quality assurance procedures. Each SRS environmental organization has developed and implemented QA procedures that address these requirements. In addition, the site's independent QA organization periodically performs QA environmental program reviews and assessments to ensure compliance with site requirements. SRS environmental professionals periodically conduct QA self-assessments on specific environmental program activities. Results, improvement opportunities, and corrective actions generated by these assessments are documented in the Site Tracking, Analysis and Reporting (STAR) system. Site management participates in the Management Field Observation process, and the results from these reviews also are documented in STAR. The focus of this chapter is on environmental laboratory QA.

\section{Program Samples Quality Assurance Program}

EML, EMP, and ACP have documented QA programs that meet SRS and DOE requirements [SRNS, 2009]. Based on inspections of instrument records and on data reviews, no corrective actions were identified during 2010.
For onsite laboratories, analytical methods and instrumentation include $\mathrm{pH}$, biological oxygen demand, fecal coliform, total residual chlorine, temperature, liquid scintillation and gas flow proportional counter, alpha and gamma spectrometry, inductively coupled plasma atomic emission spectrometry (ICP-AES), inductively coupled plasma mass spectrometry (ICPMS), flow injection mercury system (FIMS), and gas chromatography mass spectrometry (GC-MS). Analyses include hydrogen-3 (tritium), carbon-14, nickel-63, gamma-emitting isotopes (cesium-137, cobalt-60, potassium-40, plus any other detected isotopes), iodine129, strontium-89,90, strontium-90, americium-241, curium-244, neptunium-237, plutonium-238, plutonium-239, thorium-229, thorium-230, thorium-232, uranium-234, uranium-235, uranium-238, inorganic metals, mercury, and volatile organic compounds. Total suspended solids are determined by weight. Method and instrument performance is monitored through the use of QC standards and control charts. Analytical batch performance is measured through the use of QC samples (blanks, spikes, carriers, tracers, laboratory control samples, and laboratory duplicates). QC results that fall outside of specified limits may result in analytical batch or sample reruns. For those batches or samples that fall outside of limits - but for which the results are determined to be satisfactory - the reason(s) are documented in the data package, which includes the QA cover sheet, instrument data printouts, and associated QC data. 
Environmental investigations of soils and sediments, primarily for Resource Conservation and Recovery Act/Comprehensive Environmental Response, Compensation, and Liability Act units, are performed by subcontract laboratories. Data are reviewed by ACP according to U.S. Environmental Protection Agency (EPA) standards for analytical data quality, or as specified by SRS onsite customers.

The ACP environmental data review program is based in part on two EPA guidance documents, "Guidance for the Data Quality Objectives Process for Superfund" [EPA, 1993a] and "Systematic Planning: A Case Study for Hazardous Waste Site Investigations" [EPA, 2006]. These documents identify QA issues to be addressed, but they do not formulate a procedure for data evaluation or provide pass/fail criteria to apply to data and document acceptance. Hence, the SRS data review program contains elements from - and is influenced by - several other references, including

- "Guidance on Environmental Data Verification and Data Validation” (QA/G-8) [EPA, 2002b]

- "USEPA Contract Laboratory Program National Functional Guidelines for Organic Data Review" [EPA, 1999b]

- "USEPA Contract Laboratory Program National Functional Guidelines for Chlorinated Dioxin/Furan Data Review" [EPA, 2005]

- "USEPA Contract Laboratory Program National Functional Guidelines for Inorganic Data Review" [EPA, 2004]

- "Test Methods for Evaluating Solid Waste, Physical/Chemical Methods," EPA, November 1986, SW-846, Third Edition; Latest Update, February 2008 [EPA, 2008f]

- "DOE Quality Systems for Analytical Services," Revision 2.6, November 2010 [DOE, 2010]

- “Analytical Data Qualification,” ER-SOP-033, Revision 3 [SRNS, 2007]

For the ACP program, many QA parameters are evaluated by automated processing of electronically reported data. Others are selectively evaluated by manual inspection of associated analytical records. A summary of findings is presented in each project narrative or validation report prepared by ACP personnel.

An annual DOE Consolidated Audit Program (DOECAP) evaluation of each subcontract laboratory is performed to ensure that all the laboratories proficiently demonstrate technical capability and follow the required QA programs. The evaluation includes an examination of laboratory performance with regard to sample receipt, instrument calibration, analytical procedures, data verification, data reports, records management, nonconformance and corrective actions, and preventive maintenance. In 2010, evaluations were conducted at three laboratories, resulting in a total of 13 Priority II findings. A Priority II finding documents a deficiency that is not of sufficient magnitude to render the audited facility unacceptable to provide services to DOE. A report on the 2010 findings and recommendations was provided to each laboratory. For findings, each affected laboratory submitted corrective action responses, and the responses subsequently were reviewed. The findings typically are closed during the next laboratory audit (scheduled for 2011).

Evaluations also were conducted at three laboratories in 2009, resulting in 23 Priority II findings. Each laboratory submitted a corrective action response that addressed each finding. Twenty-one of the 23 Priority II findings identified during 2009 were reviewed and closed during 2010. It is anticipated that the remaining two findings will be closed out with the next scheduled audit in 2011.

\section{Laboratory Certification}

EMP is certified by the South Carolina Department of Health and Environmental Control (SCDHEC) Office of Laboratory Certification for field $\mathrm{pH}$, temperature, total residual chlorine measurements, biological oxygen demand, fecal coliform, and low-level mercury sampling.

EML is certified by the SCDHEC Office of Laboratory Certification for analytical measurements using the following methods:

- Total suspended solids (Standard Methods, 2540D), 25 metals by ICP-AES (EPA, 200.7), mercury by FIMS (EPA, 245.2), and 17 metals by ICP-MS (EPA, 200.8)

- 40 volatile organic compounds by GC-MS (EPA, 8260B), 26 metals by ICP-AES (EPA, 6010C), mercury by FIMS (EPA, 7470A and 7471B), and 15 metals by ICP-MS (EPA, 6020A)

Certificates are renewed every three years; the current certificates expire in June 2012.

National Pollutant Discharge Elimination System (NPDES) samples are analyzed by four onsite laboratory groups-EML, EMP, D-Area Powerhouse, and the Sanitary Wastewater Treatment Plant - and one offsite subcontract laboratory. All these laboratories are certified by SCDHEC for NPDES analyses. 
During 2010, all laboratories performing NPDES analyses for SRS participated in the SCDHEC-required proficiency testing studies, per State Regulation 61-81 ("State Environmental Laboratory Certification Program"). All laboratories utilized accredited proficiency testing providers, accredited by the American Association of Laboratory Accreditation.

During 2010, four full-service subcontract laboratories were used by ACP, and subcontract laboratories also participated in various water pollution studies.

The onsite and subcontract laboratories reported acceptable proficiency testing results during 2010; therefore, state certification was maintained for all analyses.

SRS lost SCDHEC certification for about two weeks during January 2010 for laboratory methods EPA 6010C, EPA 6020A, EPA 7470A, and EPA 7471A. Proficiency testing results had been completed as required in 2009; however, when reporting the results to SCDHEC, the EML made an administrative error by not specifying these methods on the report form. The reason for the error was that SCDHEC had changed the way methods were to be reported in 2009, and the change was missed by the laboratory. A new set of proficiency testing samples was analyzed by mid-January 2010 , resulting in the demonstration of satisfactory performance. SCDHEC subsequently renewed the certification for these methods by the end of the month. During this period, there was no impact on laboratory analyses or on the reporting of data to site customers.

\section{Blind pH Samples}

EMP personnel routinely conduct blind sample analyses for field measurements of $\mathrm{pH}$ to assess the quality and reliability of field data measurements. The results for blind sample analyses were acceptable during 2010. Blind $\mathrm{pH}$ sample results can be found in data table 8-1 (see "SRS Environmental Data/Maps" on the CD accompanying this report).

\section{NPDES Field Duplicate and Blind Samples}

The environmental monitoring program reviews laboratory performance by analyzing field blind and duplicate samples throughout the year.

The results for onsite and offsite laboratory blind and duplicate sample analyses indicated that, although there were some differences, no problems occurred consistently within the laboratories during 2010. For blind samples, only one value out of 70 exceeded 20 percent; for duplicate samples, only four values out of 71 exceeded 20 percent. Complete field blind and duplicate sample program results can be found in data tables 8-2 and 8-3 (see "SRS
Environmental Data/Maps" on the CD accompanying this report).

\section{Stream and River Water Quality Duplicate Samples}

SRS's water quality program requires checks of 10 percent of the samples to verify analytical results. Duplicate samples from site streams and the Savannah River were analyzed by EML and a subcontract laboratory in 2010. Results for the field duplicate sampling program indicated that, although there were some differences, no problems occurred consistently within the laboratories. Detailed stream and Savannah River field duplicate sample results can be found in data table 8-4 (see "SRS Environmental Data/Maps" on the $\mathrm{CD}$ accompanying this report).

\section{External QA Program}

EML participated during 2010 in the DOE Mixed Analyte Performance Evaluation Program (MAPEP), a laboratory comparison program that tracks performance accuracy and tests the quality of environmental data reported to DOE. The DOE Radiological and Environmental Sciences Laboratory, under the direction of the Office of Health, Safety, and Security, administers the MAPEP. MAPEP samples include water, soil, air filter, and vegetation matrices - all with environmentally important stable inorganic, organic, and radioactive constituents. Two separate studies were offered by MAPEP in 2010. In 2010, EML participated in the two studies, and the results for both studies were found to be satisfactory; out of 140 analyses, only two results were not acceptable (uranium-233,234 and uranium 238).

MAPEP results for the four full-service subcontract laboratories used by ACP in 2010 also were satisfactory, with the exception of air filter analyses for one laboratory. The laboratory evaluated the cause for the failed analyses and developed corrective actions to prevent a recurrence.

To help participants identify, investigate, and resolve potential quality concerns, MAPEP issues a letter of concern to a participating laboratory upon identification of a potential analytical data quality problem in the MAPEP results. Letters of concern have been issued since 1996, shortly after the beginning of the MAPEP program. A copy of each letter is sent to DOE/contractor oversight points of contact. Intended to be informativenot punitive - each letter states, "This letter is solely intended to alert your laboratory to a potential quality concern that you may wish to investigate for corrective action." Three subcontract laboratories were issued letters of concern in 2010 - one lab for uranium-235,238, a second for pyrene, and a third for americium- 241 . 



\section{Applicable Guidelines, Standards, and Regulations}

Jack Mayer

Savannah River National Laboratory

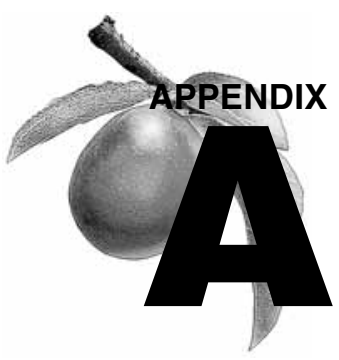

$\mathbf{T}$

he Savannah River Site (SRS) environmental monitoring program is designed to meet state and federal regulatory requirements for radiological and nonradiological programs. These requirements are stated in U.S. Department of Energy (DOE) Order 5400.5, "Radiation Protection of the Public and the Environment"; in the Clean Air Act [Standards of Performance for New Stationary Sources, also referred to as New Source Performance Standards, and the National Emission Standards for Hazardous Air Pollutants (NESHAP)]; in the Comprehensive Environmental Response, Compensation, and Liability Act (CERCLA - also known as Superfund); in the Resource Conservation and Recovery Act (RCRA); and in the Clean Water Act (i.e., National Pollutant Discharge Elimination System-NPDES).

SRS compliance with environmental requirements is assessed by the DOE-Savannah River Operations Office (DOE-SR), the South Carolina Department of Health and Environmental Control (SCDHEC), and the U.S. Environmental Protection Agency (EPA).

The SRS environmental monitoring program's objectives incorporate recommendations of

- the International Commission on Radiological Protection (ICRP) in Principles of Monitoring for the Radiation Protection of the Public, ICRP Publication 43

- DOE Order 5400.5

- DOE/EH-0173T, "Environmental Regulatory Guide for Radiological Effluent Monitoring and Environmental Surveillance"

Detailed information about the site's environmental monitoring program is documented in Procedure 101 (SRS Environmental Monitoring Program Management Plan) of the SRS Environmental Requirements and Program Documents, Manual 3Q1. This document is reviewed annually and updated every 3 years.

SRS has implemented and adheres to the SRS Environmental Policy. Implementation of a formal Environmental Management System (EMS), such as that described in the International Organization for Standardization (ISO) 14001 standard, is an Executive Order 13148 ("Greening the Government Through Leadership in Environmental Management") and DOE Order 450.1A (“Environmental Protection Program”) requirement. SRS maintains an EMS that fully meets the requirements of ISO 14001. The full text of the SRS Environmental Policy appears on the CD accompanying this report.

\section{Air Effluent Discharges}

DOE Order 5400.5 establishes derived concentration guides (DCGs) for radionuclides in air. DCGs, calculated by DOE using methodologies consistent with recommendations found in ICRP publications 26 (Recommendations of the International Commission on Radiological Protection) and 30 (Limits for Intakes of Radionuclides by Workers), are used as reference concentrations for conducting environmental protection programs at DOE sites. DCGs are not considered release limits. DCGs for radionuclides in air are discussed in more detail on page A-7.

Radiological airborne releases also are subject to EPA regulations cited in 40 CFR 61, "National Emission Standards for Hazardous Air Pollutants," Subpart $\mathrm{H}$ ("National Emission Standards for Emissions of Radionuclides Other than Radon from Department of Energy Facilities").

Regulation of radioactive and nonradioactive air emissions - both criteria pollutants and toxic air pollutants- has been delegated to SCDHEC. Therefore, SCDHEC must ensure that its air pollution regulations are at least as stringent as federal regulations required by the Clean Air Act. This is accomplished by SCDHEC Regulation 61-62, "Air Pollution Control Regulations 
and Standards." As with many regulations found in the Code of Federal Regulations (CFR), many of SCDHEC's regulations and standards are source specific. Each source of air pollution at SRS is permitted or exempted by SCDHEC, with specific emission rate limitations or special conditions identified. The bases for the limitations and conditions are the applicable South Carolina air pollution control regulations and standards. In some cases, specific applicable CFRs also are cited in the permits issued by SCDHEC. The applicable SCDHEC regulations are too numerous to discuss here, so only the most significant are listed.

Two SCDHEC standards, which govern criteria and toxic air pollutants and ambient air quality, are applicable to all SRS sources. Regulation 61-62.5, Standard No. 2, "Ambient Air Quality Standards," identifies eight criteria air pollutants commonly used as indices of air quality (e.g., sulfur dioxide, nitrogen dioxide, and lead) and provides allowable site boundary concentrations for each pollutant, as well as the measuring intervals. Compliance with the various pollutant standards is determined by conducting air dispersion modeling for all sources of each pollutant, using EPA-approved dispersion models and then comparing the results to the standard. The pollutants, measuring intervals, and allowable concentrations are provided in table A-1.

A total of 258 toxic air pollutants and their respective allowable site boundary concentrations are identified in Regulation 61-62.5, Standard No. 8, "Toxic Air Pollutants." As with Standard No. 2, compliance is determined by air dispersion modeling.

SCDHEC airborne emission standards for each SRS permitted source may differ, based on size and type of facility, type and amount of expected emissions, and the year the facility was placed into operation. For example, SRS powerhouse coal-fired boilers are regulated by Regulation 61-62.5, Standard No. 1, "Emissions from Fuel Burning Operations." This standard specifies that for powerhouse stacks built before February 11, 1971, the opacity limit is 40 percent. For new sources constructed after this date, the opacity limit typically is 20 percent. The standards for particulate and sulfur dioxide emissions are shown in table A-2.

Regulation 61-62.5, Standard No. 4, "Emissions from Process Industries," is applicable to all SRS sources except those regulated by a different source-specific standard. For some SRS sources, particulate matter emission limits depend on the weight of the material being processed and are determined from a table in the regulation. For process and diesel engine stacks in existence on or before December 31, 1985, emissions shall not exhibit an opacity greater than 40 percent. For new sources, where construction began after December 31,1985 , the opacity limit is 20 percent.

As previously noted, some SRS sources have both SCDHEC and CFRs applicable and identified in their permits. For the package steam generating boilers in K-Area and two portable package boilers, both SCDHEC and federal regulations apply. The standard for sulfur dioxide emissions is specified in 40 CFR 60, Subpart Dc, "Standards of Performance for Small IndustrialCommercial-Institutional Steam Generating Units," while the standard for particulate matter is found in Regulation 61-62.5, Standard No. 1.

Because these units were constructed after applicability dates found in both regulations, the opacity limit for the units is the same in both regulations. The emissions standards for these boilers are presented in table A-3.

The A Area steam facility (Building 784-7A), which uses a smaller, less polluting, biomass boiler and a backup oil-fired boiler, replaced the old coal-fired boilers that had operated previously in that area of the site. This new facility complies with 40 CFR 63, Subpart DDDDD standards. Both particulate and sulfur dioxide emissions at the new facility are projected to be considerably lower than at the existing coal-fired facility. The emission standards for these two new boilers are presented in tables A-4 and A-5.

\section{(Process) Liquid Effluent Discharges}

DOE Order 5400.5 establishes DCGs for radionuclides in process effluents. (DCGs for radionuclides in liquid are discussed in more detail on page A-8.) DCGs were calculated by DOE using methodologies consistent with recommendations found in ICRP, 1987, and ICRP, 1979, and are used

- as reference concentrations for conducting environmental protection programs at DOE sites

- as screening values for considering best available technology for treatment of liquid effluents

- DOE Order 5400.5 exempts aqueous tritium releases from best available technology requirements but not from ALARA (as low as reasonably achievable) considerations. 
Table A-1 National Ambient Air Quality Standards for Criteria Air Pollutants - 2010

\begin{tabular}{|c|c|c|c|c|}
\hline \multirow{2}{*}{ Pollutant } & \multicolumn{2}{|c|}{ Primary Standards } & \multicolumn{2}{|c|}{ Secondary Standards } \\
\hline & Level & Averaging Time & Level & Averaging Time \\
\hline \multirow{2}{*}{ Carbon Monoxide } & $9 \mathrm{ppm}\left(10 \mathrm{mg} / \mathrm{m}^{3}\right)$ & 8-houra & \multirow{2}{*}{\multicolumn{2}{|c|}{ None }} \\
\hline & $35 \mathrm{ppm}\left(40 \mathrm{mg} / \mathrm{m}^{3}\right)$ & 1-hour ${ }^{\mathrm{a}}$ & & \\
\hline \multirow{2}{*}{ Lead } & $0.15 \mu \mathrm{g} / \mathrm{m}^{3 \mathrm{~b}}$ & Rolling 3-Month Average & \multirow{2}{*}{\multicolumn{2}{|c|}{$\begin{array}{l}\text { Same as Primary } \\
\text { Same as Primary }\end{array}$}} \\
\hline & $1.5 \mu \mathrm{g} / \mathrm{m}^{3 \mathrm{~b}}$ & Quarterly Average & & \\
\hline \multirow{2}{*}{ Nitrogen Dioxide } & $53 \mathrm{ppb}^{\mathrm{c}}$ & Annual (Arithmetic Average) & \multirow{2}{*}{\multicolumn{2}{|c|}{$\begin{array}{c}\text { Same as Primary } \\
\text { None }\end{array}$}} \\
\hline & $100 \mathrm{ppb}$ & 1-hourd & & \\
\hline Particulate Matter $\left(\mathrm{PM}_{10}\right)$ & $150 \mu \mathrm{g} / \mathrm{m}^{3}$ & 24-houre & \multicolumn{2}{|c|}{ Same as Primary } \\
\hline \multirow{2}{*}{$\begin{array}{l}\text { Particulate Matter } \\
\left(\mathrm{PM}_{2.5}\right)\end{array}$} & $15.0 \mu \mathrm{g} / \mathrm{m}^{3}$ & Annualf (Arithmetic Average) & \multirow{2}{*}{\multicolumn{2}{|c|}{$\begin{array}{l}\text { Same as Primary } \\
\text { Same as Primary }\end{array}$}} \\
\hline & $35 \mu \mathrm{g} / \mathrm{m}^{3}$ & 24-hourg & & \\
\hline \multirow{3}{*}{ Ozone } & 0.075 ppm $(2008 \mathrm{std})$ & 8-hourh & \multicolumn{2}{|c|}{ Same as Primary } \\
\hline & 0.08 ppm (1997 std) & 8-houri & \multicolumn{2}{|c|}{ Same as Primary } \\
\hline & $0.12 \mathrm{ppm}$ & 1-hourj & \multicolumn{2}{|c|}{ Same as Primary } \\
\hline \multirow{3}{*}{ Sulfur Dioxide } & 0.03 ppm & Annual (Arithmetic Average) & \multirow{3}{*}{$0.5 \mathrm{ppm}$} & \multirow{3}{*}{ 3-houra } \\
\hline & $0.14 \mathrm{ppm}$ & 24-houra & & \\
\hline & 75 ppb & 1-hour & & \\
\hline
\end{tabular}

a Not to be exceeded more than once per year

b Final rule signed October 15, 2008

${ }^{c}$ The official level of the annual $\mathrm{NO}_{2}$ standard is $0.053 \mathrm{ppm}$, equal to $53 \mathrm{ppb}$, which is shown here for the purpose of clearer comparison to the 1-hour standard.

d To attain this standard, the 3-year average of the 98th percentile of the daily maximum 1-hour average at each monitor within an area must not exceed $100 \mathrm{ppb}$ (effective January 22, 2010).

${ }^{e}$ Not to be exceeded more than once per year on average over 3 years

$\mathrm{f}$ To attain this standard, the 3-year average of the weighted annual mean $\mathrm{PM}_{2.5}$ concentrations from single or multiple communityoriented monitors must not exceed $15.0 \mu \mathrm{g} / \mathrm{m}^{3}$.

${ }^{g}$ To attain this standard, the 3-year average of the 98th percentile of 24-hour concentrations at each population-oriented monitor within an area must not exceed $35 \mu \mathrm{g} / \mathrm{m}^{3}$ (effective December 17, 2006).

$\mathrm{h}$ To attain this standard, the 3-year average of the fourth-highest daily maximum 8-hour average ozone concentrations measured at each monitor within an area over each year must not exceed 0.075 ppm (effective May 27, 2008).

i 1 To attain this standard, the 3-year average of the fourth-highest daily maximum 8-hour average ozone concentrations measured at each monitor within an area over each year must not exceed $0.08 \mathrm{ppm}$.

2 The 1997 standard—and the implementation rules for that standard-will remain in place for implementation purposes as EPA undertakes rulemaking to address the transition from the 1997 ozone standard to the 2008 ozone standard.

${ }^{3}$ EPA is in the process of reconsidering these standards (set in March 2008).

j ${ }^{1}$ EPA revoked the 1-hour ozone standard in all areas, although some areas have continuing obligations under that standard ("anti-backsliding").

2 The standard is attained when the expected number of days per calendar year with maximum hourly average concentrations above $0.12 \mathrm{ppm}$ is $\leq 1$.

${ }^{k}$ Final rule signed June 2, 2010. To attain this standard, the 3-year average of the $99^{\text {th }}$ percentile of the daily maximum 1 -hour average at each monitor within an area must not exceed $75 \mathrm{ppb}$. 


Table A-2 $\begin{aligned} & \text { Airborne Emission Limits for } \\
& \text { SRS Coal-Fired Boilers }\end{aligned}$
\begin{tabular}{|l|}
\hline $\begin{array}{l}\text { Sulfur Dioxide } \\
\text { Total Suspended } \\
\text { Particulates } \\
\text { Opacity }\end{array}$ \\
\hline \\
\hline $\begin{array}{l}\text { a British thermal unit } \\
\text { b Heat input per hour }\end{array}$ \\
\hline
\end{tabular}

Four NPDES permits are in place that allow SRS to discharge water into site streams and the Savannah River: two industrial wastewater permits (SC0047431 and SC0000175) and two stormwater runoff permits (SCR000000 for industrial discharges and SCR100000 for construction discharges).

A fifth permit (ND0072125) is a no-discharge, waterpollution-control land application permit that regulates sludge generated at onsite sanitary waste treatment plants.

Detailed requirements for each permitted discharge point - including parameters sampled for, permit limits for each parameter, sampling frequency, and method for collecting each sample - can be found in the individual permits, which are available to the public through SCDHEC's Freedom of Information Office at 803-898-3882.

\section{Site Streams}

SRS streams are classified as "Freshwaters" by South Carolina Regulation 61-69, "Classified Waters." Freshwaters are defined in Regulation 61-68, "Water Classifications and Standards," as surface water suitable for

- $\quad$ primary- and secondary-contact recreation and as a drinking water source after conventional treatment in accordance with SCDHEC requirements

- $\quad$ fishing and the survival and propagation of a balanced indigenous aquatic community of fauna and flora

- $\quad$ industrial and agricultural uses

Table A-6 provides some of the specific South Carolina freshwater standards used in water quality surveillance, but because some of these standards are not quantifiable, they are not tracked in response form (i.e., amount of garbage found).

\section{Savannah River}

Because the Savannah River is defined under South Carolina Regulation 61-69 as a freshwater system, the river is regulated in the same manner as site streams (table A-6).

\section{Drinking Water}

The federal Safe Drinking Water Act-enacted in 1974 to protect public drinking water supplies - was amended in 1977, 1979, 1980, 1986, and 1996.

SRS drinking water systems are tested routinely by SRS and SCDHEC to ensure compliance with SCDHEC State Primary Drinking Water Regulations (R61-58) and EPA National Primary Drinking Water Regulations (40 CFR 141).

SRS drinking water is supplied to most site areas by the A-Area, D-Area, and K-Area systems, which are actively regulated by SCDHEC. Remote facilities - such as field laboratories, barricades, and pumphouses - utilize bottled water for drinking, and receive a lesser degree of regulatory oversite.

Bacteriological samples are collected and analyzed monthly or quarterly at an onsite laboratory. SCDHEC personnel periodically collect and analyze chemical and organics samples from the A-Area, D-Area, and K-Area systems. Lead and copper compliance samples are collected every 3 years from these systems. All sample results in 2010 met SCDHEC water quality standards.

\section{Groundwater}

Groundwater is a valuable resource and the subject of both protection and cleanup programs at SRS. More than 1,000 wells are monitored each year at the site for a wide range of constituents. Monitoring in the groundwater protection program is performed to detect new or unknown contamination across the site, and monitoring

Table A-3 Airborne Emission Limits for SRS Fuel Oil-Fired Package Boilers

\begin{tabular}{|ll|}
\hline Sulfur Dioxide & $0.5 \mathrm{lb} / 10^{6} \mathrm{Btu}^{\mathrm{a}, \mathrm{b}}$ \\
\hline $\begin{array}{l}\text { Total Suspended } \\
\text { Particulates }\end{array}$ & $0.6 \mathrm{lb} / 10^{6} \mathrm{Btu}^{\mathrm{a}, \mathrm{b}}$ \\
Opacity & $20 \%$ \\
\hline
\end{tabular}

${ }^{a}$ British thermal unit

${ }^{\mathrm{b}}$ Heat input per hour 
Table A-4 Airborne Emission Limits for SRS 784-7A Biomass Boiler

\begin{tabular}{|ll|}
\hline Sulfur Dioxide & $0.5 \mathrm{lb} / 10^{6} \mathrm{Btu}^{\mathrm{a}, \mathrm{b}}$ \\
\hline $\begin{array}{l}\text { Total Suspended } \\
\text { Particulates }\end{array}$ & $0.6 \mathrm{lb} / 10^{6} \mathrm{Btu} \mathrm{u}^{\mathrm{a}, \mathrm{b}}$ \\
Nitrogen Oxides & $0.33 \mathrm{lb} / 10^{6} \mathrm{Btu}^{\mathrm{a}, \mathrm{b}}$ \\
\hline Opacity & $20 \%$ \\
\hline
\end{tabular}

${ }^{a}$ British thermal unit

${ }^{\mathrm{b}}$ Heat input per hour

in the groundwater cleanup program is performed to meet the requirements of state and federal laws and regulations. Most of the monitoring in the cleanup program is governed by SCDHEC's administration of RCRA regulations.

The analytical results of samples taken from SRS monitoring wells are compared to various standards.

The most common are final federal primary drinking water standards (DWS) - or other standards if DWS do not exist. The DWS are considered first because groundwater aquifers are defined as potential drinking water sources by the South Carolina Pollution Control Act. DWS can be found at http://www.epa.gov/safewater/ standards.html on the Internet. Other standards sometimes are applied by regulatory agencies to the SRS waste units under their jurisdiction. For example, standards under RCRA can include DWS, groundwater protection standards, background levels, or alternate concentration limits.

SRS responses to groundwater analytical results require careful evaluation of the data and relevant standards. Results from two constituents having DWSdichloromethane and bis (2-ethylhexyl) phthalate-are evaluated more closely than other constituents and are commonly dismissed. Both are common laboratory contaminants and are reported in groundwater samples with little or no reproducibility. Both are reported, with appropriate flags and qualifiers, in detailed groundwater monitoring results that can be obtained by contacting the manager of the Savannah River Nuclear Solutions (SRNS) Environmental Monitoring Services group at 803-952-6937. Also, the SCDHEC standard used for lead is $50 \mu \mathrm{g} / \mathrm{L}$. The federal standard of $15 \mu \mathrm{g} / \mathrm{L}$ is a treatment standard for drinking water at the consumer's tap.

The regulatory standards for radionuclide discharges from industrial and governmental facilities are set under the Clean Water Act and under Nuclear Regulatory Commission and DOE regulations. In addition, radionuclide cleanup levels, which fall under the authority of DOE, are included in the site RCRA permit. The proposed drinking water maximum contaminant levels (MCLs) discussed in this report are only an adjunct to these release restrictions and are not used to regulate SRS groundwater.

Many potential radionuclide contaminants are beta emitters. The standard used for gross beta is a screening standard; when public drinking water exceeds this standard, the supplier is expected to analyze for individual beta and gamma emitters. A gross beta result above the standard is an indication that one or more radioisotopes are present in quantities that would exceed the EPA annual dose equivalent for persons consuming 2 liters daily. Thus, for the individual beta and gamma radioisotopes (other than strontium-90 and tritium), the standard considered is the activity per liter that would, if only that isotope were present, exceed the dose equivalent. Similarly, the standards for alpha emitters are calculated to present the same risk at the same rate of ingestion.

The element radium has several isotopes of concern in groundwater monitoring. Although radium has a DWS of $5 \mathrm{pCi} / \mathrm{L}$ for the sum of radium-226 and radium-228, the isotopes have to be measured separately, and the combined numbers may not be representative of the total. Radium-226, an alpha emitter, and radium-228, a beta emitter, cannot be analyzed by a single method. Analyses for total alpha-emitting radium, which consists of radium-223, radium-224, and radium-226, are compared to the standard for radium-226.

Table A-5 Airborne Emission Limits for SRS 784-7A Oil-Fired Package Boiler

\begin{tabular}{|ll|}
\hline Sulfur Dioxide & $3.5 \mathrm{lb} / 10^{6} \mathrm{Btu}^{\mathrm{a}, \mathrm{b}}$ \\
\hline $\begin{array}{l}\text { Sulfur Dioxide } \\
\text { Total Suspended } \\
\text { Particulates }\end{array}$ & $0.5 \%$ Sulfur \\
$\begin{array}{l}\text { Total Suspended } \\
\text { Particulates }\end{array}$ & $0.6 \mathrm{lb} / 10^{6} \mathrm{Btu}^{\mathrm{a}, \mathrm{b}}$ \\
$\begin{array}{l}\text { Nitrogen Dioxide } \\
\text { Opacity }\end{array}$ & $0.03 \mathrm{lb} / 10^{6} \mathrm{Btu}^{\mathrm{a}, \mathrm{b}}$ \\
\hline
\end{tabular}

a British thermal unit

${ }^{\mathrm{b}}$ Heat input per hour 


\begin{tabular}{|c|c|}
\hline Parameters & Standards \\
\hline Fecal coliform & $\begin{array}{l}\text { Not to exceed a geometric mean of } 200 / 100 \mathrm{~mL} \text {, } \\
\text { based on five consecutive samples during any } \\
30 \text {-day period; nor shall more than } 10 \text { percent of the } \\
\text { total samples during any } 30 \text {-day period exceed } \\
400 / 100 \mathrm{~mL}\end{array}$ \\
\hline $\mathrm{pH}$ & Range between 6.0 and 8.5 \\
\hline Temperature & $\begin{array}{l}\text { Generally, shall not be increased more than } 5^{\circ} \mathrm{F} \\
\left(2.8^{\circ} \mathrm{C}\right) \text { above natural temperature conditions or be } \\
\text { permitted to exceed a maximum of } 90^{\circ} \mathrm{F}\left(32.2^{\circ} \mathrm{C}\right) \text { as } \\
\text { a result of the discharge of heated liquids; for more } \\
\text { details, see E. } 12 \text {, Regulation } 61-68 \text {, "Water Classifications } \\
\text { and Standards" (April } 25,2008)\end{array}$ \\
\hline Dissolved oxygen & $\begin{array}{l}\text { Daily average not less than } 5.0 \mathrm{mg} / \mathrm{L} \text {, with a low of } \\
4.0 \mathrm{mg} / \mathrm{L}\end{array}$ \\
\hline Garbage, cinders, ashes, sludge, or other refuse & None allowed \\
\hline $\begin{array}{l}\text { Treated wastes, toxic wastes, deleterious } \\
\text { substances, colored or other wastes, except in } \\
\text { the parameter immediately above }\end{array}$ & $\begin{array}{l}\text { None alone or in combination with other substances } \\
\text { of wastes in sufficient amounts to make the waters } \\
\text { unsafe or unsuitable for primary-contact recreation or } \\
\text { to impair the waters for any other best usage as } \\
\text { determined for the specific waters assigned to this } \\
\text { class }\end{array}$ \\
\hline $\begin{array}{l}\text { Toxic pollutants listed in South Carolina Regulation } \\
61-68 \text {, "Water Classifications and Standards" }\end{array}$ & $\begin{array}{l}\text { See Appendix: Water Quality Numeric Criteria for } \\
\text { the Protection of Aquatic Life and Human Health, } \\
\text { Regulation } 61-68 \text {, "Water Classifications and Standards" } \\
\text { (April } 25,2008 \text { ) }\end{array}$ \\
\hline
\end{tabular}

a This is a partial list of water quality standards for freshwaters.

SOURCE: SCDHEC, 2008

Four other constituents without DWS are commonly used as indicators of potential contamination in wells.

These constituents are

- $\quad$ specific conductance at values equal to or greater than $100 \mu \mathrm{S} / \mathrm{cm}$

- alkalinity (as $\mathrm{CaCO}_{3}$ ) at values equal to or greater than $120 \mathrm{mg} / \mathrm{L}$

- $\quad$ total dissolved solids (TDS) at values equal to or greater than $500 \mathrm{mg} / \mathrm{L}$

- $\mathrm{pH}$ at values equal to or less than 6.5 or equal to or greater than 8.5

The selection of these values as standards for comparison is somewhat arbitrary; however, the values exceed levels usually found in background wells at SRS. The occurrence of elevated alkalinity (as $\mathrm{CaCO}_{3}$ ), specific conductance, $\mathrm{pH}$, and TDS within a single well also may indicate leaching of the grouting material used in well construction, rather than degradation of the groundwater.

\section{Potential Doses}

The radiation protection standards followed by SRS are outlined in DOE Order 5400.5 and include EPA regulations on the potential doses from airborne releases and treated drinking water.

The following radiation dose standards for protection of the public in the SRS vicinity are specified in DOE Order 5400.5:

- Drinking Water Pathway

4 mrem per year

- Airborne Pathway

- All Pathway

10 mrem per year

100 mrem per year

The EPA annual dose standard of 10 mrem $(0.1 \mathrm{mSv})$ for the atmospheric pathway, which is contained in $40 \mathrm{CFR}$ 61, Subpart H, is adopted in DOE Order 5400.5. 
These dose standards are based on recommendations of the ICRP and the National Council on Radiation Protection and Measurements.

The DOE dose standard enforced at SRS for drinking water is consistent with the criteria contained in "National Interim Primary Drinking Water Regulations, 40 CFR Part 141." Under these regulations, persons consuming drinking water shall not receive an annual total body or organ dose-DOE Order 5400.5 interprets this dose as committed effective dose equivalent - of more than 4 mrem $(0.04 \mathrm{mSv})$.

In 2000, EPA promulgated 40 CFR, Parts 9, 141, and 142, "National Primary Drinking Water Regulations; Radionuclides; Final Rule." This rule, which is applicable only to community drinking water systems, finalized MCLs for radionuclides, including uranium. In essence, it reestablishes the MCLs from EPA's original 1976 rule. Most of these MCLs are derived from dose conversion factors that are based on early ICRP-2 methods.

However, when calculating dose, SRS must use the more current ICRP-30-based dose conversion factors provided by DOE. Because they are based on different methods, most EPA and DOE radionuclide dose conversion factors differ. Therefore, a direct comparison of the drinking water doses calculated for showing compliance with DOE Order 5400.5 to the EPA drinking water MCLs cannot be made.

\section{Comparison of Average Concentrations in Airborne Emissions to DOE Derived Concentration Guides}

Average concentrations of radionuclides in airborne emissions are calculated by dividing the yearly release total of each radionuclide from each stack by the yearly stack flow quantities. These average concentrations then can be compared to the DOE DCGs, which are found in DOE Order 5400.5 for each radionuclide.

DCGs are used as reference concentrations for conducting environmental protection programs at all DOE sites. DCGs, which are based on a 100-mrem exposure, are applicable at the point of discharge (prior to dilution or dispersion) under conditions of continuous exposure (assumed to be an average inhalation rate of 8,400 cubic meters per year). This means that the DOE DCGs are based on the highly conservative assumption that a member of the public has direct access to, and continuously breathes (or is immersed in), the actual air effluent 24 hours a day, 365 days a year. However, because of the large distance between most SRS operating facilities and the site boundary, this scenario is improbable.

Average annual radionuclide concentrations in SRS air effluent can be referenced to DOE DCGs as a screening method to determine if existing effluent treatment systems are proper and effective.

\section{Comparison of Average Concentrations in Liquid Releases to DOE Derived Concentration Guides}

In addition to dose standards, DOE Order 5400.5 imposes other control considerations on liquid releases. These considerations are applicable to direct discharges but not to seepage basin and Solid Waste Disposal Facility migration discharges. The DOE order lists DCG values for most radionuclides. DCGs are used as reference concentrations for conducting environmental protection programs at all DOE sites. These DCG values are not release limits but screening values for bestavailable-technology investigations and for determining whether existing effluent treatment systems are proper and effective.

Per DOE Order 5400.5, exceedance of the DCGs at any discharge point may require an investigation of bestavailable-technology waste treatment for the liquid effluents. Tritium in liquid effluents is specifically excluded from best available technology requirements; however, it is not excluded from other ALARA considerations. DOE DCG compliance is demonstrated when the sum of the fractional DCG values for all radionuclides detectable in the effluent is less than 1.00, based on consecutive 12-month average concentrations.

DCGs, based on a 100-mrem exposure, are applicable at the point of discharge from the effluent conduit to the environment (prior to dilution or dispersion). They are based on the highly conservative assumption that a member of the public has continuous direct access to the actual liquid effluents and consumes 2 liters of the effluents every day, 365 days a year. Because of security controls and the considerable distances between most SRS operating facilities and the site boundary, this scenario is highly improbable, if not impossible. For each SRS facility that releases radioactivity, the site's Environmental Monitoring group compares the monthly liquid effluent concentrations and 12-month average concentrations against the DOE DCGs. 


\section{Environmental Management}

SRS began its cleanup program in 1981. Two major federal statutes provide guidance for the site's environmental restoration and waste management activities-RCRA and CERCLA. RCRA addresses the management of hazardous waste and requires that permits be obtained for facilities that treat, store, or dispose of hazardous or mixed waste. It also requires that DOE facilities perform appropriate corrective action to address contaminants in the environment. CERCLA (also known as Superfund) addresses the uncontrolled release of hazardous substances and the cleanup of inactive waste sites. This act established a National Priority List of sites targeted for assessment and, if necessary, corrective/remedial action. SRS was placed on this list December 21, 1989 [EPA, 1989]. In August 1993, SRS entered into the Federal Facility Agreement (FFA) [FFA, 1993] with EPA Region IV and SCDHEC. This agreement governs the corrective/remedial action process from site investigation through site remediation. It also describes procedures for setting annual work priorities, including schedules and deadlines, for that process [FFA under section 120 of CERCLA and sections 3008(h) and 6001 of RCRA].

Additionally, DOE is complying with Federal Facility Compliance Act requirements for mixed waste management - including high-level waste, most transuranic waste, and low-level waste with hazardous constituents. This act requires that DOE develop and submit site treatment plans to the EPA or state regulators for approval.

The disposition of facilities after they are declared excess to the government's mission is managed by Site Area Completion Projects. The disposition process is conducted in accordance with DOE Order 430.1B, "Real Property Asset Management," and its associated guidance documents. The major emphases are reducing risks to workers and the public and minimizing real property asset lifecycle costs.

\section{Quality Assurance/ Quality Control}

DOE Order 414.1C, "Quality Assurance," sets requirements and guidelines for departmental quality assurance (QA) practices. To ensure compliance with regulations and to provide overall quality requirements for site programs, the current site management and operations contractor (SRNS) developed its Quality Assurance Management Plan (SRNS-RP-2008-00020). The plan's requirements are implemented by the SRNS Quality Assurance Manual (1Q).

The SRS Environmental Monitoring Quality Assurance Project Plan (3Q1, Procedure 102), was written to apply the QA requirements of Manual 1Q to the environmental monitoring and surveillance program. The $3 \mathrm{Q} 1$ manual includes procedures on sampling, analysis, and reporting that emphasize the quality control requirements for the Environmental Monitoring group.

QA requirements for monitoring radiological air emissions are specified in 40 CFR 61, "National Emission Standards for Hazardous Air Pollutants." For radiological air emissions at SRS, the responsibilities and lines of communication are detailed in National Emission Standards for Hazardous Air Pollutants Quality Assurance Project Plan for Radionuclides (U) (WSRC-IM-91-60).

To ensure valid and defensible monitoring data, the records and data generated by the monitoring program are maintained according to the requirements of DOE Guide 1324.5B, "Implementation Guide for Use with 36 CFR Chapter XII - Subchapter B Records Management," and of 1Q. QA records include sampling and analytical procedure manuals, logbooks, chainof-custody forms, calibration and training records, analytical notebooks, control charts, validated laboratory data, and environmental reports. These records are maintained and stored per the requirements of the SRNS Retention Schedule Matrix (WSRC-EM-96-00023).

Environmental Monitoring group assessments are implemented according to the following documents:

- DOE Order 414.1C

- DOE/EH-0173T

- DOE Environmental Management Consolidated Audit Program (EMCAP)

- SRNS 1Q, Quality Assurance Manual

- SRNS 12Q, Assessment Manual

Figure A-1 illustrates the hierarchy of relevant guidance documents that support the SRS QA program. 


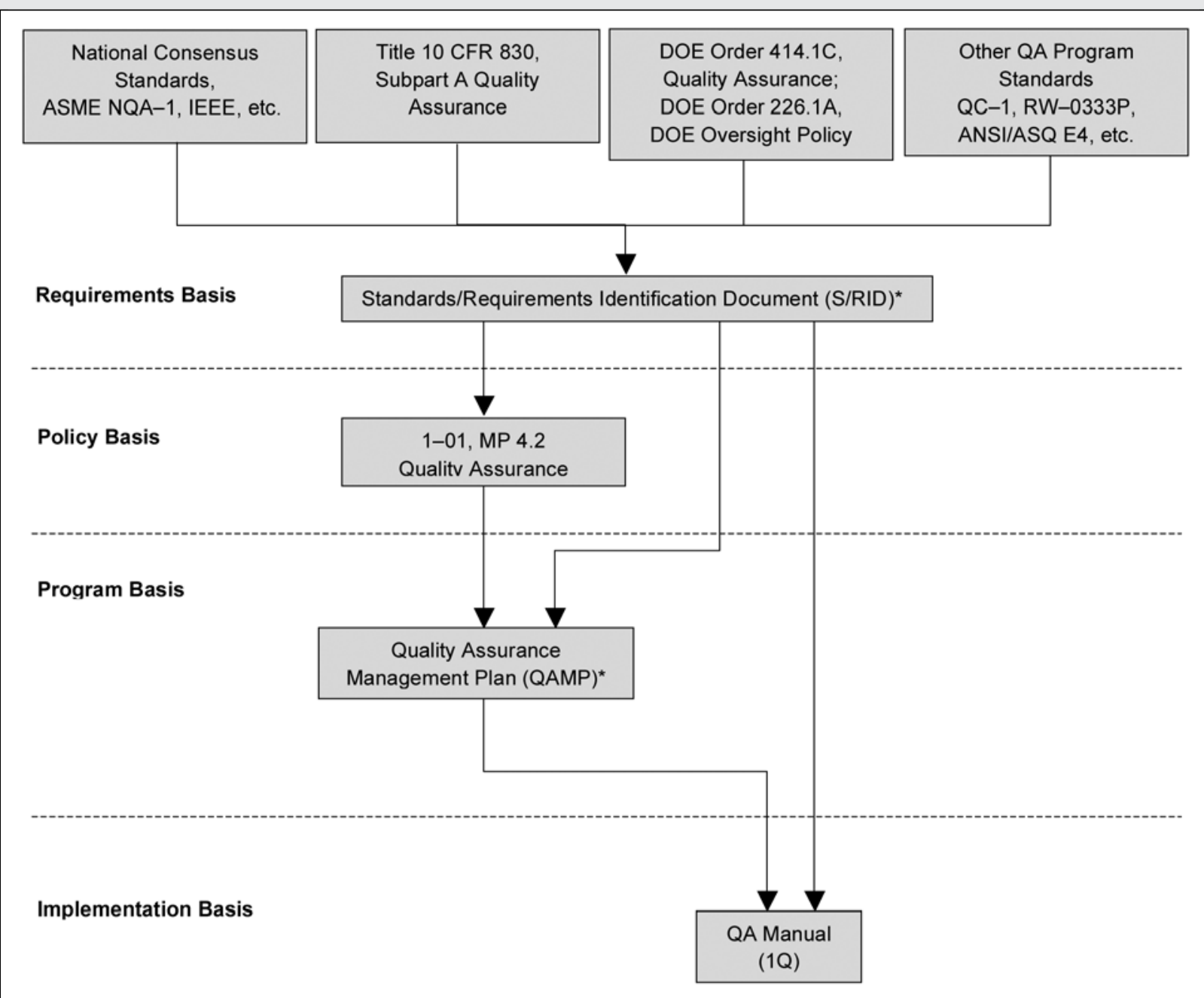

*Documents approved by DOE-SR/NNSA-SRSO, as required

References to the standards, guidance, and documents cited in this figure can be found in SRS, 2008 (see References, page R-3).

Figure A-1 SRS EM Program QA Document Hierarchy

This diagram depicts the hierarchy of relevant guidance and supporting documents for the SRS QA program.

\section{Reporting}

DOE Orders 231.1A, "Environment, Safety and Health Reporting," and 5400.5, "Radiation Protection of the Public and Environment," require that SRS submit an annual environmental report.
This report, the SRS Environmental Report for 2010, is an overview of effluent monitoring and environmental surveillance activities conducted on and in the vicinity of SRS from January 1 through December 31, 2010. 



\section{Radionuclide and Chemical Nomenclature}

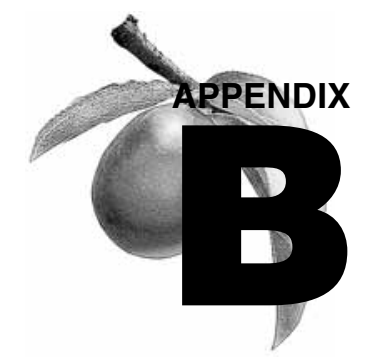

\begin{tabular}{|c|c|c|c|c|c|}
\hline & & & & & Page 1 \\
\hline \multicolumn{6}{|c|}{ Nomenclature and Half-Life for Radionuclides } \\
\hline Radionuclide & Symbol & Half-life ${ }^{a, b}$ & Radionuclide & Symbol & Half-life $e^{a, b}$ \\
\hline Actinium-228 & Ac-228 & $6.15 \mathrm{~h}$ & lodine-129 & $\mathrm{I}-129$ & 1.57E7 y \\
\hline Americium-241 & Am-241 & $432.7 \mathrm{y}$ & lodine-131 & $\mathrm{I}-131$ & $8.020 d$ \\
\hline Americium-243 & Am-243 & 7.37E3 y & lodine-133 & $\mathrm{I}-133$ & $20.8 \mathrm{~h}$ \\
\hline Antimony-124 & Sb-124 & $60.20 d$ & Krypton-85 & $\mathrm{Kr}-85$ & $10.76 \mathrm{y}$ \\
\hline Antimony-125 & $\mathrm{Sb}-125$ & $2.758 \mathrm{y}$ & Lead-212 & $\mathrm{Pb}-212$ & $10.64 \mathrm{~h}$ \\
\hline Argon-39 & Ar-39 & $269 y$ & Lead-214 & $\mathrm{Pb}-214$ & $27 \mathrm{~m}$ \\
\hline Barium-133 & Ba-133 & $10.53 \mathrm{y}$ & Manganese-54 & Mn-54 & $312.1 \mathrm{~d}$ \\
\hline Beryllium-7 & $\mathrm{Be}-7$ & $53.3 d$ & Mercury-203 & $\mathrm{Hg}-203$ & $46.61 \mathrm{~d}$ \\
\hline Bismuth-212 & $\mathrm{Bi}-212$ & $1.009 \mathrm{~h}$ & Neptunium-237 & $\mathrm{Np}-237$ & 2.14E6 y \\
\hline Bismuth-214 & $\mathrm{Bi}-214$ & $19.9 \mathrm{~m}$ & Neptunium-239 & $\mathrm{Np}-239$ & $2.355 d$ \\
\hline Carbon-14 & C-14 & $5715 y$ & Nickel-59 & $\mathrm{Ni}-59$ & 7.6E4 y \\
\hline Cerium-141 & Ce-141 & $32.50 \mathrm{~d}$ & Nickel-63 & $\mathrm{Ni}-63$ & $101 \mathrm{y}$ \\
\hline Cerium-144 & $\mathrm{Ce}-144$ & $284.6 \mathrm{~d}$ & Niobium-94 & $\mathrm{Nb}-94$ & 2.0E4 y \\
\hline Cesium-134 & Cs-134 & $2.065 \mathrm{y}$ & Niobium-95 & $\mathrm{Nb}-95$ & $34.99 \mathrm{~d}$ \\
\hline Cesium-137 & Cs-137 & $30.07 \mathrm{y}$ & Plutonium-238 & Pu-238 & 87.7 y \\
\hline Chromium-51 & Cr-51 & $27.702 \mathrm{~d}$ & Plutonium-239 & Pu-239 & $2.41 \mathrm{E} 4 \mathrm{y}$ \\
\hline Cobalt-57 & Co-57 & $271.8 d$ & Plutonium-240 & Pu-240 & $6.56 \mathrm{E} 3 \mathrm{y}$ \\
\hline Cobalt-58 & Co-58 & $70.88 d$ & Plutonium-241 & Pu-241 & $14.4 \mathrm{y}$ \\
\hline Cobalt-60 & Co-60 & $5.271 \mathrm{y}$ & Plutonium-242 & Pu-242 & 3.75E5 y \\
\hline Curium-242 & $\mathrm{Cm}-242$ & $162.8 \mathrm{~d}$ & Potassium-40 & $\mathrm{K}-40$ & 1.27E9 y \\
\hline Curium-244 & $\mathrm{Cm}-244$ & $18.1 \mathrm{y}$ & Praseodymium-144 & Pr-144 & $17.28 \mathrm{~m}$ \\
\hline Curium-245 & $\mathrm{Cm}-245$ & 8.5E3 y & Praseodymium-144m & $\operatorname{Pr}-144 \mathrm{~m}$ & $7.2 \mathrm{~m}$ \\
\hline Curium-246 & $\mathrm{Cm}-246$ & 4.76E3 y & Promethium-147 & Pm-147 & $2.6234 \mathrm{y}$ \\
\hline Europium-152 & Eu-152 & $13.54 \mathrm{y}$ & Protactinium-231 & $\mathrm{Pa}-231$ & $3.28 \mathrm{E} 4 \mathrm{y}$ \\
\hline Europium-154 & Eu-154 & $8.593 y$ & Protactinium-233 & $\mathrm{Pa}-233$ & $29.967 d$ \\
\hline Europium-155 & Eu-155 & $4.75 \mathrm{y}$ & Protactinium-234 & $\mathrm{Pa}-234$ & $6.69 \mathrm{~h}$ \\
\hline
\end{tabular}




\begin{tabular}{|c|c|c|c|c|c|}
\hline \multicolumn{6}{|c|}{ Nomenclature and Half-Life for Radionuclides (cont.) } \\
\hline Radionuclide & Symbol & Half-life $e^{a, b}$ & Radionuclide & Symbol & Half-life $e^{a, b}$ \\
\hline Radium-226 & Ra-226 & $1599 y$ & Thorium-234 & Th-234 & $24.10 d$ \\
\hline Radium-228 & Ra-228 & $5.76 y$ & Tin-113 & Sn-113 & $115.1 \mathrm{~d}$ \\
\hline Ruthenium-103 & Ru-103 & $39.27 d$ & Tin-126 & Sn-126 & 2.3E5 $\mathrm{y}$ \\
\hline Ruthenium-106 & $\mathrm{Ru}-106$ & $1.020 y$ & Tritium (Hydrogen-3) & $\mathrm{H}-3$ & 12.32 y \\
\hline Selenium-75 & Se-75 & $119.78 d$ & Uranium-232 & U-232 & $69.8 \mathrm{y}$ \\
\hline Selenium-79 & Se-79 & $2.9 \mathrm{E} 5 \mathrm{y}$ & Uranium-233 & U-233 & $1.592 E 5 y$ \\
\hline Sodium-22 & $\mathrm{Na}-22$ & $2.604 \mathrm{y}$ & Uranium-234 & U-234 & $2.46 \mathrm{E} 5 \mathrm{y}$ \\
\hline Strontium-89 & Sr-89 & $50.52 \mathrm{~d}$ & Uranium-235 & U-235 & 7.04E8 y \\
\hline Strontium-90 & Sr-90 & 28.78 y & Uranium-236 & $\mathrm{U}-236$ & $2.342 E 7$ y \\
\hline Technetium-99 & Tc-99 & 2.13E5 y & Uranium-238 & $U-238$ & 4.47E9 y \\
\hline Thallium-208 & TI-208 & $3.053 \mathrm{~m}$ & Xenon-135 & Xe-135 & $9.10 \mathrm{~h}$ \\
\hline Thorium-228 & Th-228 & $1.912 y$ & Zinc-65 & Zn-65 & $243.8 d$ \\
\hline Thorium-230 & Th-230 & 7.54E4 y & Zirconium-85 & Zr-85 & $7.9 \mathrm{~m}$ \\
\hline Thorium-232 & Th-232 & $1.40 \mathrm{E} 10 \mathrm{y}$ & Zirconium-95 & Zr-95 & $64.02 \mathrm{~d}$ \\
\hline
\end{tabular}

${ }^{\mathrm{a}} \mathrm{m}=$ minute; $\mathrm{h}=$ hour; $\mathrm{d}=$ day; $\mathrm{y}=$ year

${ }^{b}$ Reference: Chart of the Nuclides, 16th edition, revised 2002, Lockheed Martin Company 


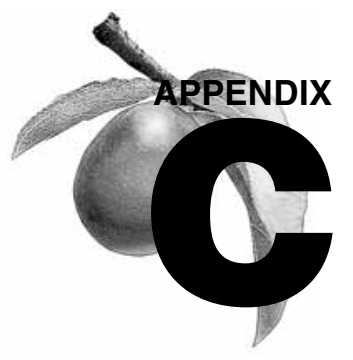

The following entry corrects information that was reported inaccurately in the Savannah River Site Environmental Report for 2009 (WSRC-STI-2010-00175):

- Page 6-4, table 6-1: The 12-month-average-concentration unit of measure was indicated as $\mathrm{pCi} / \mathrm{mL}$; it should have been $\mathrm{pCi} / \mathrm{L}$. 



\section{Glossary}

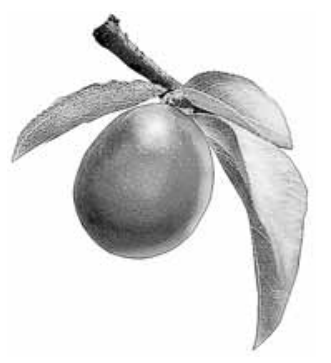

\section{A}

accuracy - Closeness of the result of a measurement to the true value of the quantity.

actinide - Group of elements of atomic number 89 through 103. Laboratory analysis of actinides by alpha spectrometry generally refers to the elements plutonium, americium, uranium, and curium but may also include neptunium and thorium.

activity - See radioactivity.

air flow - Rate of flow, measured by mass or volume per unit of time.

air stripping - Process used to decontaminate groundwater by pumping the water to the surface, "stripping" or evaporating the chemicals in a specially designed tower, and pumping the cleansed water back to the environment.

aliquot - Quantity of sample being used for analysis.

alkalinity - Alkalinity is a measure of the buffering capacity of water, and since $\mathrm{pH}$ has a direct effect on organisms as well as an indirect effect on the toxicity of certain other pollutants in the water, the buffering capacity is important to water quality.

alpha particle - Positively charged particle emitted from the nucleus of an atom having the same charge and mass as that of a helium nucleus (two protons and two neutrons).

ambient air - Surrounding atmosphere as it exists around people, plants, and structures.

analyte - Constituent or parameter that is being analyzed.

analytical detection limit - Lowest reasonably accurate concentration of an analyte that can be detected; this value varies depending on the method, instrument, and dilution used.

aquifer - Saturated, permeable geologic unit that can transmit significant quantities of water under ordinary hydraulic gradients.

aquitard - Geologic unit that inhibits the flow of water.

Atomic Energy Commission - Federal agency created in 1946 to manage the development, use, and control of nuclear energy for military and civilian application. It was abolished by the Energy Reorganization Act of 1974 and succeeded by the Energy Research and Development Administration. Functions of the Energy Research and Development Administration eventually were taken over by the U.S. Department of Energy and the U.S. Nuclear Regulatory Commission.

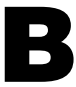

background radiation - Naturally occurring radiation, fallout, and cosmic radiation. Generally, the lowest level of radiation obtainable within the scope of an analytical measurement, i.e., a blank sample.

bailer - Container lowered into a well to remove water. The bailer is allowed to fill with water and then is removed from the well.

best management practices - Sound engineering practices that are not required by regulation or by law.

beta particle - Negatively charged particle emitted from the nucleus of an atom. It has a mass and charge equal to those of an electron.

blank - A sample that has not been exposed to the sample stream in order to monitor contamination during sampling, transport, storage, or analysis. The blank is subjected to the usual analytical and measurement process to establish a zero-baseline or -background 
value, and sometimes is used to adjust or correct routine analytical results.

blind blank - Sample container of deionized water sent to a laboratory under an alias name as a quality control check.

blind replicate - In the Environmental Services Section groundwater monitoring program, a second sample taken from the same well at the same time as the primary sample, assigned an alias well name, and sent to a laboratory for analysis (as an unknown to the analyst).

blind sample - A subsample for analysis with a composition known to the submitter. The analyst/ laboratory may know the identity of the sample, but not its composition. It is used to test the analyst's or laboratory's proficiency in the execution of the measurement process.

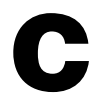

calibration - Process of applying correction factors to equate a measurement to a known standard. Generally, a documented measurement control program of charts, graphs, and data that demonstrate that an instrument is properly calibrated.

Carolina bay - Type of shallow depression commonly found on the coastal Carolina plains. Carolina bays are typically circular or oval. Some are wet or marshy, while others are dry.

Central Savannah River Area (CSRA) - Eighteencounty area in Georgia and South Carolina surrounding Augusta, Georgia. The Savannah River Site is included in the Central Savannah River Area. Counties are Richmond, Columbia, McDuffie, Burke, Emanuel, Glascock, Jenkins, Jefferson, Lincoln, Screven, Taliaferro, Warren, and Wilkes in Georgia and Aiken, Edgefield, Allendale, Barnwell, and McCormick in South Carolina.

chemical oxygen demand - Indicates the quantity of oxidizable materials present in water.

chlorocarbons - Compounds of carbon and chlorine, or carbon, hydrogen, and chlorine, such as carbon tetrachloride, chloroform, tetrachloroethylene, etc. They are among the most significant and widespread environmental contaminants. Classified as hazardous wastes, chlorocarbons may have a tendency to cause detrimental effects, such as birth defects. cleanup - Actions taken to deal with release or potential release of hazardous substances. This may mean complete removal of the substance; it also may mean stabilizing, containing, or otherwise treating the substance so that it does not affect human health or the environment.

closure - Control of a hazardous waste management facility under Resource Conservation and Recovery Act requirements.

compliance - Fulfillment of applicable requirements of a plan or schedule ordered or approved by government authority.

composite - A blend of more than one portion to be used as a sample for analysis.

\section{Comprehensive Environmental Response,} Compensation, and Liability Act (CERCLA) - This act addresses the cleanup of hazardous substances and establishes a National Priority List of sites targeted for assessment and, if necessary, restoration (commonly known as "Superfund").

\section{Comprehensive Environmental Response,} Compensation, and Liability Act (CERCLA)reportable release - Release to the environment that exceeds reportable quantities as defined by the Comprehensive Environmental Response, Compensation, and Liability Act.

concentration - Amount of a substance contained in a unit volume or mass of a sample.

conductivity - Measure of water's capacity to convey an electric current. This property is related to the total concentration of the ionized substances in a water and the temperature at which the measurement is made.

contamination - State of being made impure or unsuitable by contact or mixture with something unclean, bad, etc.

count - Signal that announces an ionization event within a counter; a measure of the radiation from an object or device.

counting geometry - Well-defined sample size and shape for which a counting system has been calibrated.

criteria pollutant - Six common air pollutants found all over the United States. They are particle pollution (often referred to as particulate matter), ground-level ozone, 
carbon monoxide, sulfur oxides, nitrogen oxides, and lead. EPA is required by the Clean Air Act to set National Ambient Air Quality Standards for these six pollutants.

cross talk - The fraction of all recorded pulses from alpha particles that are recorded in the beta channel due to degradation in their pulse height or the fraction of all recorded pulses from beta particles that are recorded in the alpha channel due to pulse pileup or other phenomenon.

curie - Unit of radioactivity. One curie is defined as 3.7 x $10^{10}$ (37 billion) disintegrations per second. Several fractions and multiples of the curie are commonly used:

kilocurie (kCi) - $10^{3} \mathrm{Ci}$, one thousand curies; $3.7 \mathrm{x}$ $10^{13}$ disintegrations per second.

millicurie (mCi) $-10^{-3} \mathrm{Ci}$, one-thousandth of a curie; $3.7 \times 10^{7}$ disintegrations per second.

microcurie $(\mu \mathrm{Ci})-10^{-6} \mathrm{Ci}$, one-millionth of a curie; $3.7 \times 10^{4}$ disintegrations per second.

picocurie (pCi) - $10^{-12} \mathrm{Ci}$, one-trillionth of a curie; 0.037 disintegrations per second.

\section{D}

decay (radioactive) - Spontaneous transformation of one radionuclide into a different radioactive or nonradioactive nuclide, or into a different energy state of the same radionuclide.

decay time - Time taken by a quantity to decay to a stated fraction of its initial value.

deactivation - The process of placing a facility in a stable and known condition, including the removal of hazardous and radioactive materials to ensure adequate protection of the worker, public health and safety, and the environment - thereby limiting the long-term cost of surveillance and maintenance.

decommissioning - Process that takes place after deactivation and includes surveillance and maintenance, decontamination, and/or dismantlement.

decontamination - The removal or reduction of residual radioactive and hazardous materials by mechanical, chemical, or other techniques to achieve a stated objective or end condition. decommissioning and demolition - Program that reduces the environmental and safety risks of surplus facilities at SRS.

derived concentration guide - Concentration of a radionuclide in air or water that, under conditions of continuous exposure for one year by one exposure mode (i.e., ingestion of water, submersion in air, or inhalation), would result in either an effective dose equivalent of 0.1 rem $(1 \mathrm{mSv})$ or a dose equivalent of $5 \mathrm{rem}(50 \mathrm{mSv})$ to any tissue, including skin and lens of the eye. The guides for radionuclides in air and water are given in U.S. Department of Energy Order 5400.5.

detection limit - See analytical detection limit, lower limit of detection, minimum detectable concentration.

detector - Material or device (instrument) that is sensitive to radiation and can produce a signal suitable for measurement or analysis.

diatometer - Diatom collection equipment consisting of a series of microscope slides in a holder that is used to determine the amount of algae in a water system.

diatoms - Unicellular or colonial algae of the class Bacillariophyceae, having siliceous cell walls with two overlapping, symmetrical parts. Diatoms represent the predominant periphyton (attached algae) in most water bodies and have been shown to be reliable indicators of water quality.

disposal - Permanent or temporary transfer of U.S. Department of Energy control and custody of real property to a third party, which thereby acquires rights to control, use, or relinquish the property.

disposition - Those activities that follow completion of program mission - including, but not limited to, surveillance and maintenance, deactivation, and decommissioning.

dissolved oxygen - Desirable indicator of satisfactory water quality in terms of low residuals of biologically available organic materials. Dissolved oxygen prevents the chemical reduction and subsequent leaching of iron and manganese from sediments.

dose - Energy imparted to matter by ionizing radiation. The unit of absorbed dose is the rad, equal to 0.01 joules per kilogram in any medium. 
absorbed dose - Quantity of radiation energy absorbed by an organ, divided by the organ's mass. Absorbed dose is expressed in units of rad (or gray) (1 $\mathrm{rad}=0.01 \mathrm{~Gy})$.

dose equivalent - Product of the absorbed dose (rad) in tissue and a quality factor. Dose equivalent is expressed in units of rem (or sievert) $(1 \mathrm{rem}=0.01$ sievert).

committed dose equivalent - Calculated total dose equivalent to a tissue or organ over a 50 -year period after known intake of a radionuclide into the body. Contributions from external dose are not included. Committed dose equivalent is expressed in units of rem (or sievert).

committed effective dose equivalent - Sum of the committed dose equivalents to various tissues in the body, each multiplied by the appropriate weighting factor. Committed effective dose equivalent is expressed in units of rem (or sievert).

effective dose equivalent - Sum of the dose equivalents received by all organs or tissues of the body after each one has been multiplied by an appropriate weighting factor. The effective dose equivalent includes the committed effective dose equivalent from internal deposition of radionuclides and the effective dose equivalent attributable to sources external to the body.

collective dose equivalent/collective effective dose equivalent - Sums of the dose equivalents or effective dose equivalents of all individuals in an exposed population within a 50 -mile $(80-\mathrm{km})$ radius, and expressed in units of person-rem (or personsievert). When the collective dose equivalent of interest is for a specific organ, the units would be organ-rem (or organ-sievert). The 50-mile distance is measured from a point located centrally with respect to major facilities or U.S. Department of Energy program activities.

dosimeter - Portable detection device for measuring the total accumulated exposure to ionizing radiation.

downgradient - In the direction of decreasing hydrostatic head.

drinking water standards - Federal primary drinking water standards, both proposed and final, as set forth by the U.S. Environmental Protection Agency. duplicate result - Result derived by taking a portion of a primary sample and performing the identical analysis on that portion as is performed on the primary sample.

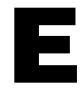

effluent - Any treated or untreated air emission or liquid discharge to the environment.

effluent monitoring - Collection and analysis of samples or measurements of liquid and gaseous effluents for purpose of characterizing and quantifying the release of contaminants, assessing radiation exposures of members to the public, and demonstrating compliance with applicable standards.

environmental compliance - Actions taken in accordance with government laws, regulations, orders, etc., that apply to site operations' effects on onsite and offsite natural resources and on human health; used interchangeably in this document with regulatory compliance.

environmental monitoring - Program at Savannah River Site that includes effluent monitoring and environmental surveillance with dual purpose of (1) showing compliance with federal, state, and local regulations, as well as with U.S. Department of Energy orders, and (2) monitoring any effects of site operations on onsite and offsite natural resources and on human health.

environmental restoration - U.S. Department of Energy program that directs the assessment and cleanup of inactive waste units and groundwater (remediation) contaminated as a result of nuclear-related activities.

environmental surveillance - Collection and analysis of samples of air, water, soil, foodstuffs, biota, and other media from U.S. Department of Energy sites and their environs and the measurement of external radiation for purpose of demonstrating compliance with applicable standards, assessing radiation exposures to members of the public, and assessing effects, if any, on the local environment.

exception (formerly "exceedance") - Term used by the U.S. Environmental Protection Agency and the South Carolina Department of Health and Environmental Control that denotes a report value is more than the upper guide limit. This term is found on the discharge monitoring report forms that are submitted to the Environmental Protection Agency or the South Carolina Department of Health and Environmental Control. 
exposure (radiation) - Incidence of radiation on living or inanimate material by accident or intent. Background exposure is the exposure to natural background ionizing radiation. Occupational exposure is the exposure to ionizing radiation that takes place during a person's working hours. Population exposure is the exposure to the total number of persons who inhabit an area.

exposure pathway - Route that materials follow to get to the environment and then to people.

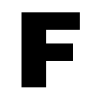

fallout - See worldwide fallout.

Federal Facility Agreement (FFA) - Agreement negotiated among the U.S. Department of Energy, the U.S. Environmental Protection Agency, and the South Carolina Department of Health and Environmental Control, specifying how the Savannah River Site will address contamination or potential contamination to meet regulatory requirements at site waste units identified for evaluation and, if necessary, cleanup.

feral hog - Hog that has reverted to the wild state from domestication.

field duplicates - Independent samples collected as closely as possible to the same point in space and time. They are two separate samples taken from the same source, stored in separate containers, and analyzed independently.

\section{G}

gamma ray - High-energy, short-wavelength electromagnetic radiation emitted from the nucleus of an excited atom. Gamma rays are identical to X-rays except for the source of the emission.

gamma-emitter - Any nuclide that emits a gamma ray during the process of radioactive decay. Generally, the fission products produced in nuclear reactors.

gamma spectrometry - System consisting of a detector, associated electronics, and a multichannel analyzer that is used to analyze samples for gamma-emitting radionuclides.

grab sample - Sample collected instantaneously with a glass or plastic bottle placed below the water surface to collect surface water samples (also called dip samples).
H

half-life (radiological) - Time required for half of a given number of atoms of a specific radionuclide to decay. Each nuclide has a unique half-life.

heavy water - Water in which the molecules contain oxygen and deuterium, an isotope of hydrogen that is heavier than ordinary hydrogen.

hydraulic gradient - Difference in hydraulic head over a specified distance.

hydrology - Science that treats the occurrence, circulation, distribution, and properties of the waters of the earth, and their reaction with the environment.

IAPCR - Interim Action Post Closure Report

ICP-AES - Inductively coupled plasma atomic emission spectrometry

ICP-MS - Inductively coupled plasma mass spectrometry

ICRP - International Commission on Radiological Protection

ISMS - Integrated Safety Management System

ISO - International Organization for Standardization

laboratory blank - Deionized water sample generated by the laboratory; a laboratory blank is analyzed with each batch of samples as an in-house check of analytical procedures. Also called an internal blank.

laboratory control sample - A sample matrix, free from the analytes of interest, spiked with verified known amounts of analytes or a material containing known and verified amounts of analytes. It generally is used to establish intralaboratory or analyst-specific precision and bias, or to assess the performance of all or a portion of the measurement system.

laboratory duplicate - Aliquot of a sample taken from the same container under laboratory conditions and processed and analyzed independently. 
legacy - Anything handed down from the past; inheritance, as of nuclear waste.

lower limit of detection - Smallest concentration/amount of an analyte that can be reliably detected in a sample at a 95-percent confidence level.

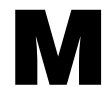

macroinvertebrates - Size-based classification used for a variety of insects and other small invertebrates; as defined by the U.S. Environmental Protection Agency, those organisms that are retained by a No. 30 (590-micron) U.S. Standard Sieve.

macrophyte - A plant that can be observed with the naked eye.

manmade radiation - Radiation from sources such as consumer products, medical procedures, and nuclear industry.

maximally exposed individual - Hypothetical individual who remains in an uncontrolled area and would, when all potential routes of exposure from a facility's operations are considered, receive the greatest possible dose equivalent.

maximum contaminant level - The maximum allowable concentration of a drinking water contaminant as legislated through the Safe Drinking Water Act

mean relative difference - Percentage error based on statistical analysis.

mercury - Silver-white, liquid metal solidifying at $-38.9^{\circ} \mathrm{C}$ to form a tin-white, ductile, malleable mass. It is widely distributed in the environment and biologically is a nonessential or nonbeneficial element. Human poisoning due to this highly toxic element has been clinically recognized.

migration - Transfer or movement of a material through the air, soil, or groundwater.

minimum detectable concentration - Smallest amount or concentration of a radionuclide that can be distinguished in a sample by a given measurement system at a preselected counting time and at a given confidence level.

moderate - To reduce the excessiveness of; to act as a moderator. moderator - Material, such as heavy water, used in a nuclear reactor to moderate or slow down neutrons from the high velocities at which they are created in the fission process.

monitoring - Process whereby the quantity and quality of factors that can affect the environment and/or human health are measured periodically to regulate and control potential impacts.

$\mathbf{N}$

nonroutine radioactive release - Unplanned or nonscheduled release of radioactivity to the environment.

nuclide - Atom specified by its atomic weight, atomic number, and energy state. A radionuclide is a radioactive nuclide.

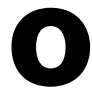

opacity - The reduction in visibility of an object or background as viewed through the diameter of a plume.

organic - Of, relating to, or derived from living organisms (plant or animal).

outcrop - Place where groundwater is discharged to the surface. Springs, swamps, and beds of streams and rivers are the outcrops of the water table.

outfall - Point of discharge (e.g., drain or pipe) of wastewater or other effluents into a ditch, pond, or river.

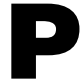

parameter - Analytical constituent; chemical compound(s) or property for which an analytical request may be submitted.

permeability - Physical property that describes the ease with which water may move through the pore spaces and cracks in a solid.

person-rem - Collective dose to a population group. For example, a dose of one rem to 10 individuals results in a collective dose of 10 person-rem.

pH - Measure of the hydrogen ion concentration in an aqueous solution (acidic solutions, $\mathrm{pH}<7$; basic solutions, $\mathrm{pH}>7$; and neutral solutions, $\mathrm{pH}=7$ ). 
piezometer - Instrument used to measure the potentiometric surface of the groundwater. Also, a well designed for this purpose.

plume - Volume of contaminated air or water originating at a point-source emission (e.g., a smokestack) or at a waste source (e.g., a hazardous waste disposal site).

point source - Any defined source of emission to air or water such as a stack, air vent, pipe, channel, or passage to a water body.

population dose - See collective dose equivalent under dose.

process sewer - Pipe or drain, generally located underground, used to carry off process water and/or waste matter.

purge - To remove water prior to sampling, generally by pumping or bailing.

purge water - Water that has been removed prior to sampling; water that has been released to seepage basins to allow a significant part of tritium to decay before the water outcrops to surface streams and flows to the Savannah River.

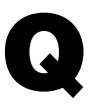

quality assurance (QA) - In the Environmental Monitoring System program, QA consists of the system whereby the laboratory can assure clients and other outside entities, such as government agencies and accrediting bodies, that the laboratory is generating data of proven and known quality.

quality control (QC) - In the Environmental Monitoring System program, QC refers to those operations undertaken in the laboratory to ensure that the data produced are generated within known probability limits of accuracy and precision.

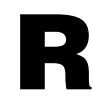

rad - Unit of absorbed dose deposited in a volume of material.

radioactivity - Spontaneous emission of radiation, generally alpha or beta particles, or gamma rays, from the nucleus of an unstable isotope. radioisotopes - Radioactive isotopes.

radionuclide - Unstable nuclide capable of spontaneous transformation into other nuclides by changing its nuclear configuration or energy level. This transformation is accompanied by the emission of photons or particles.

real-time instrumentation - Operation in which programmed responses to an event essentially are simultaneous to the event itself.

reforestation - Process of planting new trees on land once forested.

regulatory compliance - Actions taken in accordance with government laws, regulations, orders, etc., that apply to Savannah River Site operations' effects on onsite and offsite natural resources and on human health; used interchangeably in this document with environmental compliance.

release - Any discharge to the environment. Environment is broadly defined as any water, land, or ambient air.

rem - Unit of dose equivalent (absorbed dose in rads $\mathrm{x}$ the radiation quality factor). Dose equivalent frequently is reported in units of millirem (mrem), which is onethousandth of a rem.

remediation - Assessment and cleanup of U.S. Department of Energy sites contaminated with waste as a result of past activities. See environmental restoration.

remediation design - Planning aspects of remediation, such as engineering characterization, sampling studies, data compilation, and determining a path forward for a waste site.

replicate - In the Environmental Services Section groundwater monitoring program, a second sample from the same well taken at the same time as the primary sample and sent to the same laboratory for analysis.

\section{Resource Conservation and Recovery Act (RCRA)}

Federal legislation that regulates the transport, treatment, and disposal of solid and hazardous wastes. This act also requires corrective action for releases of hazardous waste at inactive waste units.

Resource Conservation and Recovery Act (RCRA) site - Solid waste management unit under Resource Conservation and Recovery Act regulation. See Resource Conservation and Recovery Act. 
retention basin - Unlined basin used for emergency, temporary storage of potentially contaminated cooling water from chemical separations activities.

RFI/RI Program - RCRA Facility Investigation/ Remedial Investigation Program. At the Savannah River Site, the expansion of the RFI Program to include Comprehensive Environmental Response, Compensation, and Liability Act and hazardous substance regulations.

routine radioactive release - Planned or scheduled release of radioactivity to the environment.

\section{8}

seepage basin - Excavation that receives wastewater. Insoluble materials settle out on the floor of the basin and soluble materials seep with the water through the soil column, where they are removed partially by ion exchange with the soil. Construction may include dikes to prevent overflow or surface runoff.

sensitivity - Capability of methodology or instruments to discriminate between samples with differing concentrations or containing varying amounts of analyte.

settling basin - Temporary holding basin (excavation) that receives wastewater that subsequently is discharged.

sievert - The International System of Units (SI)derived unit of dose equivalent. It attempts to reflect the biological effects of radiation as opposed to the physical aspects, which are characterized by the absorbed dose, measured in gray. One sievert is equal to $100 \mathrm{rem}$.

site stream - Any natural stream on the Savannah River Site. Surface drainage of the site is via these streams to the Savannah River.

source - Point or object from which radiation or contamination emanates.

source check - Radioactive source (with a known amount of radioactivity) used to check the performance of the radiation detector instrument.

source term - Quantity of radioactivity (released in a set period of time) that is traceable to the starting point of an effluent stream or migration pathway.

spent nuclear fuel - Used fuel elements from reactors. spike - Addition, to a blank sample, of a known amount of reference material containing the analyte of interest.

stable - Not radioactive or not easily decomposed or otherwise modified chemically.

stack - Vertical pipe or flue designed to exhaust airborne gases and suspended particulate matter.

standard deviation - Indication of the dispersion of a set of results around their average.

stormwater runoff - Surface streams that appear after precipitation.

Superfund - See Comprehensive Environmental Response, Compensation, and Liability Act (CERCLA).

supernate - Portion of a liquid above settled materials in a tank or other vessel.

surface water - All water on the surface of the earth, as distinguished from groundwater.

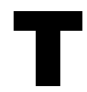

tank farm - Installation of interconnected underground tanks for storage of high-level radioactive liquid wastes.

temperature - Thermal state of a body, considered with its ability to communicate heat to other bodies.

thermoluminescent dosimeter (TLD) - Device used to measure external gamma radiation.

total dissolved solids - Dissolved solids and total dissolved solids are terms generally associated with freshwater systems; they consist of inorganic salts, small amounts of organic matter, and dissolved materials.

total phosphorus - May occasionally stimulate excessive or nuisance growths of algae and other aquatic plants when concentrations exceed $25 \mathrm{mg} / \mathrm{L}$ at the time of the spring turnover on a volume-weighted basis in lakes or reservoirs.

total suspended particulates - Refers to the concentration of particulates in suspension in the air, regardless of the nature, source, or size of the particulates.

transport pathway - Pathway by which a released contaminant is transported physically from its point of discharge to a point of potential exposure to humans. 
Typical transport pathways include the atmosphere, surface water, and groundwater.

transuranic waste - Solid radioactive waste containing primarily alpha-emitting elements heavier than uranium.

trend - General drift, tendency, or pattern of a set of data plotted over time.

turbidity - Measure of the concentration of sediment or suspended particles in solution.

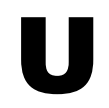

unspecified alpha and beta emissions - The unidentified alpha and beta emissions that are determined at each effluent location by subtracting the sum of the individually measured alpha-emitting (e.g., plutonium-239 and uranium-235) and beta-emitting (e.g., cesium-137 and strontium-90) radionuclides from the measured gross alpha and beta values, respectively.

\section{V}

vitrify - Change into glass.

vitrification - Process of changing into glass.

volatile organic compounds - Broad range of organic compounds, commonly halogenated, that vaporize at ambient, or relatively low, temperatures (e.g., acetone, benzene, chloroform, methyl alcohol).
$\mathbf{W}$

waste management - The U.S. Department of Energy uses this term to refer to the safe, effective management of various kinds of nonhazardous, hazardous, and radioactive waste generated at Savannah River Site.

waste unit - An inactive area known to have received contamination or to have had a release to the environment.

water table - Planar, underground surface beneath which earth materials, such as soil or rock, are saturated with water.

weighting factor - Value used to calculate dose equivalents. It is tissue specific and represents the fraction of the total health risk resulting from uniform, whole-body irradiation that could be attributed to that particular tissue. The weighting factors used in this report are recommended by the International Commission on Radiological Protection (Publication 26).

wetland - Lowland area, such as a marsh or swamp, inundated or saturated by surface or groundwater sufficiently to support hydrophytic vegetation typically adapted for life in saturated soils.

wind rose - Diagram in which statistical information concerning wind direction and speed at a location is summarized.

worldwide fallout - Radioactive debris from atmospheric weapons tests that has been deposited on the earth's surface after being airborne and cycling around the earth. 



\section{References}

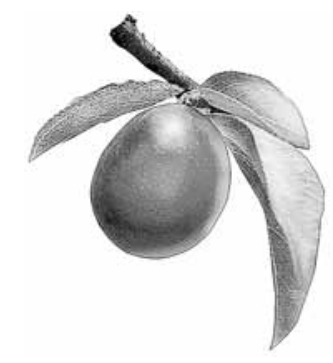

Aadland et al., 1995 Aadland, R.K., J.A. Gellici, and P.A. Thayer, 1995, "Hydrogeologic Framework of West-Central South Carolina," Report 5, Water Resources Division, South Carolina Department of Natural Resources, Columbia, S.C.

APHA, 1992 American Public Health Association, 1992, Method 2540D, "Total Suspended Solids Dried at 103-105 C," Standard Methods for the Examination of Water and Wastewater, Washington, D.C.

Carlton et al., 1994 Carlton, W.H., C.E. Murphy, Jr., and A.G. Evans, 1994, "Radiocesium in the Savannah River Site Environment," Health Physics, Volume 67, Number 3, Williams \& Wilkins, Baltimore, Md.

Cherry, 2006 Cherry, G.S., 2006, "Simulation and Particle-Tracking Analysis of Ground-Water Flow near the Savannah River Site, Georgia and South Carolina, 2002, and for Selected Ground-Water Management Scenarios, 2002 and 2020," Scientific Investigations Report, 2006-5195, U.S. Geological Survey, Reston, Virginia.

Clarke and West, 1998 Clarke, J.S., and C.T. West, 1998, "Ground-Water Levels, Predevelopment Ground-Water Flow, and Stream-Aquifer Relations in the Vicinity of the Savannah River Site, Georgia and South Carolina," U.S. Geological Survey Water-Resources Investigations Report 974197, U.S. Geological Survey, Reston, Va.

DOE, 1988 U.S. Department of Energy, 1988, External and Internal Dose Conversion Factors for Calculation of Dose to the Public, DOE/EH-0070 \& 71, Washington, D.C.

DOE, 1995 U.S. Department of Energy, 1995, Memorandum, Pelletier to Pearson: "Requirements for Control of Settleable Solids," Air, Water, and Radiation Division: EH-412, December 1995, Washington, D.C.

DOE, 2002 U.S. Department of Energy, 2002, A Graded Approach for Evaluating Radiation Doses to Aquatic and Terrestrial Biota, DOE Standard, DOE-STD-1153-2002, July 2002, Washington, D.C.

DOE, 2010 U.S. Department of Energy, 2010, “DOE Quality Systems for Analytical Services,” Revision 2.6, November 2010, Washington, D.C.

EPA, 1974 U.S. Environmental Protection Agency, 1974, Method 245.2, Mercury (Automated Cold Vapor Technique), "Clean Water Act Analytical Methods," Washington, D.C.

EPA, 1989 U.S. Environmental Protection Agency, 1989, "National Priorities List for Uncontrolled Hazardous Waste Sites," Federal Register, Volume 54, Number 223, November 21, pp. 48184-48189, Washington, D.C.

EPA, 1993a U.S. Environmental Protection Agency, 1993, "Guidance for the Data Quality Objectives Process for Superfund" (EPA-540-R-93-071), Washington, D.C.

EPA, 1993b U.S. Environmental Protection Agency, 1993, "External Exposure to Radionuclides in Air, Water, and Soil, Federal Guidance Report No. 12” (EPA 402-R-93-081), Washington, D.C.

EPA, 1994a U.S. Environmental Protection Agency, 1994, Method 200.7, "Determination of Trace Elements in Waters and Wastes by Inductively Coupled Plasma-Atomic Emission Spectrometry," Revision 4.4, Methods for the Determination of Metals in Environmental Samples, Supplement I, Washington, D.C. 
EPA, 1994b U.S. Environmental Protection Agency, 1994, Method 200.8, "Determination of Trace Elements in Waters and Wastes by Inductively Coupled Plasma-Mass Spectrometry," Revision 5.4, Methods for the Determination of Metals in Environmental Samples, Supplement I, Washington, D.C.

EPA, 1999a U.S. Environmental Protection Agency, 1999, "Cancer Risk Coefficients for Environmental Exposure to Radionuclides,” Federal Guidance Report No.13, EPA 402-R-99-001, September 1999, Washington, D.C.

EPA, 1999b U.S. Environmental Protection Agency, 1999, "USEPA Contract Laboratory Program National Functional Guidelines for Organic Data Review" (EPA-540/R-99/008), Washington, D.C.

EPA, 2002a U.S. Environmental Protection Agency, 2002, "National Emission Standards for Hazardous Air Pollutants," Title 40 Code of Federal Regulations, Part 61, Subpart H, September 2002, Washington, D.C.

EPA, 2002b U.S. Environmental Protection Agency, 2002, "Guidance on Environmental Data Verification and Data Validation,” (QA/G-8) (EPA-240/R-02/004), Washington, D.C.

EPA, 2004 U.S. Environmental Protection Agency, 2004, "USEPA Contract Laboratory Program National Functional Guidelines for Inorganic Data Review" (EPA-540/R-04/004), Washington, D.C.

EPA, 2005 U.S. Environmental Protection Agency, 2005, "USEPA Contract Laboratory Program National Functional Guidelines for Chlorinated Dioxin/Furan Data Review" (EPA-540/R-05/001), Washington, D.C.

EPA, 2006 U.S. Environmental Protection Agency, 2006, "Systematic Planning: A Case Study for Hazardous Waste Site Investigations" (QA/CS-1) (EPA/240/B-06/004), Washington, D.C.

EPA, 2008a U.S. Environmental Protection Agency, 2008, Method 6010C, "Inductively Coupled Plasma-Atomic Emission Spectrometry," Revision 1, Test Methods for Evaluating Solid Waste, Physical/Chemical Methods (SW-846), Washington, D.C.

EPA, 2008b U.S. Environmental Protection Agency, 2008, Method 6020A, "Inductively Coupled Plasma-Mass Spectrometry," Revision 1, Test Methods for Evaluating Solid Waste, Physical/Chemical Methods (SW-846), Washington, D.C.

EPA, 2008c U.S. Environmental Protection Agency, 2008, Method 7470A, "Mercury in Liquid Water, Cold Vapor Technique," Revision 1, Test Methods for Evaluating Solid Waste, Physical/Chemical Methods (SW-846), Washington, D.C.

EPA, 2008d U.S. Environmental Protection Agency, 2008, Method 7471B, "Mercury in Solid or Semisolid Waste, Cold Vapor Technique," Revision 1, Test Methods for Evaluating Solid Waste, Physical/Chemical Methods (SW-846), Washington, D.C.

EPA, 2008e U.S. Environmental Protection Agency, 2008, Method 8260B, "Volatile Organic Compounds by Gas Chromatography/Mass Spectrometry (GC/MS): Capillary Column Technique," Revision 2, Test Methods for Evaluating Solid Waste, Physical/Chemical Methods (SW-846), Washington, D.C.

EPA, $2008 f$ U.S. Environmental Protection Agency, 2008, “Test Methods for Evaluating Solid Waste, Physical/ Chemical Methods,” EPA, November 1986, SW-846, Third Edition; Latest Update, February 2008, Washington, D.C.

Fallaw and Price, 1995 Fallaw, W.C., and V. Price, 1995, "Stratigraphy of the Savannah River Site and Vicinity," Southeastern Geology, Vol. 35, No. 1, March 1995, pp. 21-58, Duke University, Durham, N.C.

FFA, 1993 Federal Facility Agreement for the Savannah River Site, 1993, Administrative Docket Number 89-05-FF, August 16, 1993, WSRC-OS-94-42, Savannah River Site, Aiken, S.C. 
Fledderman et al., 2007 Fledderman, P.D., G.T. Jannik, and M.H. Paller, 2007, “An Overview of Cesium-137 Contamination in a Southeastern Swamp Environment," Operational Radiation Safety 93(3), pp. S160-S164, November 2007, Hagerstown, Md.

Hamby and Bauer, 1994 Hamby, D.M., and L.R. Bauer, 1994, "The Vegetation-to-Air Concentration Ratio in a Specific Activity Atmospheric Tritium Model," Health Physics, Volume 66, Number 3, Williams \& Wilkins, Baltimore, Md.

ICRP, 1996 Annals of the ICRP, 1996, Publication 72, “Age-Dependent Doses to Members of the Public from Intake of Radionuclides: Part 5 Compilation of Ingestion and Inhalation Dose Coefficients," International Commission on Radiological Protection, 26(1), Stockholm, Sweden.

Jannik et al., 2010 Jannik, G.T., D.J. Karapatakis, P.L. Lee, E.B. Farfan, 2010, "Land and Water Use Characteristics and Human Health Input Parameters for use in Environmental Dosimetry and Risk Assessments at the Savannah River Site,”SRNL-STI-2010-00447, Savannah River National Laboratory, Aiken, S.C.

Kabela, 2010 Kabela, E.D., 2010, “Air Dispersion Modeling for the SRS Title V Permit Renewal," SRNL-L22002010-00009, Savannah River National Laboratory, Aiken, S.C.

Mamatey et al., 2007 Mamatey, A.R., P.D. Fledderman, and G.T. Jannik, 2007, SRS Environmental Report for 2006, WSRC-TR-2007-00008, Savannah River Site, Aiken, S.C.

NRC, 1977 U.S. Nuclear Regulatory Commission, 1977, Regulatory Guide 1.109, Calculation of Annual Doses to Man from Routine Releases of Reactor Effluents for the Purpose of Evaluating Compliance with 10 CFR 50, Appendix I, Revision 1, Washington, D.C.

SCDHEC, 2008 South Carolina Department of Health and Environmental Control, 2008, "Water Classifications and Standards," South Carolina Code of Regulations, R.61-68, Columbia, S.C.

Smits et al., 1996 Smits, A.D., M.K. Harris, K.L. Hawkins, and G.P. Flach, 1996, "Integrated Hydrogeological Model of the General Separations Area, Volume 1: Hydrogeological Framework," WSRC-TR-96-0399, Revision 0, Westinghouse Savannah River Company, Aiken, S.C.

SRARP, 2010 Savannah River Archaeological Research Program, 2010, “Annual Review of Cultural Resources Investigations by the Savannah River Archaeological Research Program, Fiscal Year 2010," South Carolina Institute of Archaeology and Anthropology, University of South Carolina, Columbia, S.C.

SRNS, 2007 Savannah River Nuclear Solutions, 2007, “Analytical Data Qualification,” ER-SOP-033, Revision 3, Savannah River Site, Aiken, S.C.

SRNS, 2009 Savannah River Nuclear Solutions, 2009, Procedure Manual L3.25, "Environmental Monitoring Quality Assurance Procedures," Savannah River Site, Aiken, S.C.

SRS, 2008 Savannah River Site, 2008, SRS Quality Assurance Manual (1Q), Savannah River Site, Aiken, SC.

SRS, 2010 Savannah River Site, 2010, SRS Waste Acceptance Criteria Manual (1S), Procedure 3.17, "Low Level Waste Acceptance Criteria," Savannah River Site, Aiken, S.C.

SRS EDAM, 2010 Environmental Dose Assessment Manual, 2010, SRNL-TR-2010-00274, Revision 0, Savannah River National Laboratory, Aiken, S.C.

SRS Data, 1995 Environmental Protection Department, Environmental Monitoring Section, 1995, Savannah River Site Environmental Data for 1994, WSRC-TR-95-077, Savannah River Site, Aiken, S.C. 
SRS EM Plan, 2010 Savannah River Site Environmental Monitoring Program Management Plan, 2010, SRS3Q1-101, Revision 0, Savannah River Site, Aiken, S.C.

SRS EM QA Plan, 2010 Savannah River Site Environmental Monitoring Quality Assurance Project Plan, 2010, SRS3Q1-102, Revision 0, Savannah River Site, Aiken, S.C.

Yu et al., 2001 C. Yu, A.J. Zielen, J.J. Cheng, D.J. LePoire, E. Gnanapragasam, S. Kamboj, Arnish, A. Wallo III, W.A. Williams, and H. Peterson, Users Manual for RESRAD Version 6, Argonne National Laboratory Report, ANL/EAD/4, July 2001, Argonne, Ill. 


\begin{tabular}{|c|c|c|c|}
\hline \multicolumn{4}{|c|}{ Units of Measure } \\
\hline Symbol & Name & Symbol & Name \\
\hline Temperature & & Concentration & \\
\hline${ }^{\circ} \mathrm{C}$ & degrees Centigrade & $\mathrm{ppb}$ & parts per billion \\
\hline${ }^{\circ} \mathrm{F}$ & degrees Fahrenheit & ppm & parts per million \\
\hline Time & & Rate & \\
\hline$d$ & day & cfs & cubic feet per second \\
\hline $\mathrm{h}$ & hour & gpm & gallons per minute \\
\hline $\mathrm{y}$ & year & & \\
\hline & & Conductivity & \\
\hline Length & & $\mu \mathrm{mho}$ & micromho \\
\hline $\mathrm{cm}$ & centimeter & & \\
\hline $\mathrm{ft}$ & foot & Radioactivity & \\
\hline in & inch & $\mathrm{Ci}$ & curie \\
\hline $\mathrm{km}$ & kilometer & $\mathrm{cpm}$ & counts per minute \\
\hline $\mathrm{m}$ & meter & $\mathrm{mCi}$ & millicurie \\
\hline $\mathrm{mm}$ & millimeter & $\mu \mathrm{Ci}$ & microcurie \\
\hline$\mu \mathrm{m}$ & micrometer & $\mathrm{pCi}$ & picocurie \\
\hline & & $\mathrm{Bq}$ & becquerel \\
\hline Mass & & & \\
\hline$g$ & gram & Radiation Dose & \\
\hline $\mathrm{kg}$ & kilogram & mrad & millirad \\
\hline $\mathrm{mg}$ & milligram & mrem & millirem \\
\hline$\mu g$ & microgram & Sv & sievert \\
\hline & & $\mathrm{mSv}$ & millisievert \\
\hline Area & & $\mu S v$ & microsievert \\
\hline $\mathrm{mi}^{2}$ & square mile & $\mathrm{R}$ & roentgen \\
\hline $\mathrm{ft}^{2}$ & square foot & $\mathrm{mR}$ & milliroentgen \\
\hline & & $\mu \mathrm{R}$ & microroentgen \\
\hline Volume & & Gy & gray \\
\hline gal & gallon & & \\
\hline L & liter & & \\
\hline $\mathrm{mL}$ & milliliter & & \\
\hline
\end{tabular}




\begin{tabular}{|ccccc|}
\hline \multicolumn{5}{c}{ Fractions and Multiples of Units } \\
\hline Multiple & Decimal Equivalent & Prefix & Symbol & Report Format \\
$10^{6}$ & $1,000,000$ & mega- & $\mathrm{M}$ & $\mathrm{E}+06$ \\
$10^{3}$ & 1,000 & kilo- & $\mathrm{k}$ & $\mathrm{E}+03$ \\
$10^{2}$ & 100 & hecto- & $\mathrm{h}$ & $\mathrm{E}+02$ \\
10 & 10 & deka- & $\mathrm{da}$ & $\mathrm{E}+01$ \\
$10^{-1}$ & 0.1 & deci- & $\mathrm{d}$ & $\mathrm{E}-01$ \\
$10^{-2}$ & 0.01 & centi- & $\mathrm{c}$ & $\mathrm{E}-02$ \\
$10^{-3}$ & 0.001 & milli- & $\mathrm{m}$ & $\mathrm{E}-03$ \\
$10^{-6}$ & 0.000001 & micro- & $\mu$ & $\mathrm{E}-06$ \\
$10^{-9}$ & 0.000000001 & nano- & $\mathrm{n}$ & $\mathrm{E}-09$ \\
$10^{-12}$ & 0.000000000001 & pico- & $\mathrm{p}$ & $\mathrm{E}-12$ \\
$10^{-15}$ & 0.000000000000001 & femto- & $\mathrm{f}$ & $\mathrm{E}-15$ \\
$10^{-18}$ & 0.000000000000000001 & atto- & $\mathrm{a}$ & $\mathrm{E}-18$ \\
\hline
\end{tabular}

\begin{tabular}{|lll|}
\hline \multicolumn{2}{|c|}{ Conversion Table (Units of Radiation Measure) } \\
\hline Current System & Systéme International & Conversion \\
curie $(\mathrm{Ci})$ & becquerel $(\mathrm{Bq})$ & $1 \mathrm{Ci}=3.7 \times 10^{10} \mathrm{~Bq}$ \\
rad (radiation absorbed dose) & gray (Gy) & $1 \mathrm{rad}=0.01 \mathrm{~Gy}$ \\
rem (roentgen equivalent man) & sievert $(\mathrm{Sv})$ & $1 \mathrm{rem}=0.01 \mathrm{~Sv}$ \\
\hline
\end{tabular}

\begin{tabular}{|lll|lll|}
\hline \multicolumn{5}{c|}{ Conversion Table } \\
\hline Multiply & By & To Obtain & Multiply & By & To Obtain \\
$\mathrm{in}$ & 2.54 & $\mathrm{~cm}$ & $\mathrm{~cm}$ & 0.394 & $\mathrm{in}$. \\
$\mathrm{ft}$ & 0.305 & $\mathrm{~m}$ & $\mathrm{~m}$ & 3.28 & $\mathrm{ft}$ \\
$\mathrm{mi}$ & 1.61 & $\mathrm{~km}$ & $\mathrm{~km}$ & 0.621 & $\mathrm{mi}$ \\
$\mathrm{lb}$ & 0.4536 & $\mathrm{~kg}$ & $\mathrm{~kg}$ & 2.205 & $\mathrm{lb}$ \\
$\mathrm{liq} \mathrm{qt-US}$ & 0.946 & $\mathrm{~L}$ & $\mathrm{~L}$ & 1.057 & $\mathrm{liq} \mathrm{qt}-\mathrm{US}$ \\
$\mathrm{ft}^{2}$ & 0.093 & $\mathrm{~m}^{2}$ & $\mathrm{~m}^{2}$ & 10.764 & $\mathrm{ft}^{2}$ \\
$\mathrm{mi}{ }^{2}$ & 2.59 & $\mathrm{~km}$ & $\mathrm{~km}{ }^{2}$ & 0.386 & $\mathrm{mi}$ \\
$\mathrm{ft}$ & 0.028 & $\mathrm{~m}^{3}$ & $\mathrm{~m}^{3}$ & 35.31 & $\mathrm{ft}^{3}$ \\
$\mathrm{~d} / \mathrm{m}$ & 0.450 & $\mathrm{pCi}$ & $\mathrm{pCi}$ & 2.22 & $\mathrm{~d} / \mathrm{m}$ \\
$\mathrm{pCi}$ & $10^{-6}$ & $\mu \mathrm{Ci}$ & $\mu \mathrm{Ci}$ & $10^{6}$ & $\mathrm{pCi}$ \\
$\mathrm{pCi} / \mathrm{L}$ (water) & $10^{-9}$ & $\mu \mathrm{Ci} / \mathrm{mL}$ (water) & $\mu \mathrm{Ci} / \mathrm{mL}$ (water) & $10^{9}$ & $\mathrm{pCi} / \mathrm{L}$ (water) \\
$\mathrm{pCi} / \mathrm{m}^{3}$ (air) & $10^{-12}$ & $\mu \mathrm{Ci} / \mathrm{mL}$ (air) & $\mu \mathrm{Ci} / \mathrm{mL}$ (air) & $10^{12}$ & $\mathrm{pCi} / \mathrm{m}^{3}$ (air) \\
& & & & \\
\hline
\end{tabular}

